Florida International University FIU Digital Commons

$11-7-2016$

\title{
(Un)Making the Food Desert: Food, Race, and Redevelopment in Miami's Overtown Community
}

William Hall

Florida International University, whallo02@fiu.edu

DOI: $10.25148 /$ etd.FIDC001200

Follow this and additional works at: https://digitalcommons.fiu.edu/etd

Part of the African American Studies Commons, Human Geography Commons, and the Social History Commons

\section{Recommended Citation}

Hall, William, "(Un)Making the Food Desert: Food, Race, and Redevelopment in Miami's Overtown Community" (2016). FIU Electronic Theses and Dissertations. 3033.

https://digitalcommons.fiu.edu/etd/3033 


\section{FLORIDA INTERNATIONAL UNIVERSITY}

Miami, Florida

(UN)MAKING THE FOOD DESERT: FOOD, RACE, AND REDEVELOPMENT IN MIAMI'S OVERTOWN COMMUNITY

A dissertation submitted in partial fulfillment of the

requirements for the degree of

DOCTOR OF PHILOSOPHY

in

GLOBAL AND SOCIOCULTURAL STUDIES

by

William B. Hall

2016 
To: Dean John F. Stack, Jr.

Steven J. Green School of International and Public Affairs

This dissertation written by William B. Hall, and entitled (Un)Making the Food Desert:

Food, Race, and Redevelopment in Miami's Overtown Community, having been approved in respect to style and intellectual content, is referred to you for judgment.

We have read this dissertation and recommend that it be approved.

April Merleaux

Andrea Queeley

Laura Ogden

Roderick Neumann

Gail Hollander, Major Professor

Date of Defense: November 7, 2016

The dissertation of William B. Hall is approved.

Dean John F. Stack, Jr.

Steven J. Green School of International and Public Affairs

Andrés G. Gil

Vice President for Research and Economic Development and Dean of the University Graduate School

Florida International University, 2016 
(C) Copyright 2016 by William B. Hall

All rights reserved. 


\section{ACKNOWLEDGMENTS}

This research was only made possible because of the generous contributions and guiding support I received from several people. Firstly, I wish to express my gratitude to those who live and work in Overtown and invited me to share in their company during my field research. These moments of connection have profoundly expanded my worldview, political consciousness, and sense of compassion. I am forever grateful - and indebted.

Secondly, I want to thank FIU for a Dissertation Year Fellowship in 2016 and the University of California, Santa Barbara's Department of Black Studies for a research fellowship in 2015, which provided generous funding for my project. Having the financial freedom to focus exclusively on my work ensured the timely publication of this dissertation.

Over the past six and half years, several of the students and faculty I met in FIU's Global \& Sociocultural Studies department gave me regular doses of much needed perspective, insight, joy, laughter, and love. In particular, I wish to thank Brittany Kiessling, Defne Sarsilmaz, Jacqueline Lyon, Alex Huezo, Derrick Scott, Oceane Jasor, Caroline Faria, Janna Lafferty, Julia Meszaros, Kimiko Tanita, Melissa Bernardo, Sheila Sutton, Jackal Tanelorn, and Anna Clark. In addition, the friends I made at the Ethnographic Field School in Tallahassee will always have a place in my heart. I am also thankful to have met Maria Fernanda Escallón at UC Santa Barbara, who is a big ball of light. Together, these friendships breathed life in me in ways I am only beginning to appreciate. 
My dissertation committee needs special recognition for their instrumental role in shaping my project from beginning to end and supporting my personal goals and growth. April Merleaux offered crucial insights and tools for exploring the historical aspects of my work. Andrea Queeley’s careful and critical review of my research pushed me to think more deeply about the nuances of Miami's racial and cultural politics. Laura Ogden provided foundational mentorship at several stages of my graduate career, and continues to do so. Rod Neumann is perhaps the most incisive editor I have ever met. He carved ample space and time away from his busy role as department chair to help me craft better proposals, papers, and dissertation chapters. Finally, Gail Hollander is the best advisor I could have asked for. She not only facilitated my entry into the graduate program, but since day one gave me the ropes and unconditional support I needed to climb through it. She devoted countless hours helping me think through my project, improve my writing, and become a better scholar and person. When life became too intense, she gave me a shoulder to cry on and healthy (usually organic!) treats to munch on. I am so very grateful for her guidance, wisdom, compassion, love, and friendship.

Finally, I must recognize my wonderfully weird and beautiful family, namely my sisters, my mother, my dog/son, and my wife, to whom I owe everything. In particular, my mother, Regina, is a superhuman with an unbounded capacity for love. My wife, Melissa, has tirelessly stood by me, held me up, and many times put me back together, always gracefully and tenderly. This work is for you. 


\title{
ABSTRACT OF THE DISSERTATION \\ (UN)MAKING THE FOOD DESERT: FOOD, RACE, AND REDEVELOPMENT IN \\ MIAMI'S OVERTOWN COMMUNITY
}

\author{
by
}

William B. Hall

Florida International University, 2016

Miami, Florida

\section{Professor Gail Hollander, Major Professor}

In recent years, efforts to transform food environments have played a key role in urban revitalization strategies. On one hand, concerns over urban food deserts have spurred efforts to attract supermarkets to places where access to healthy food is difficult for lower income residents. On the other, the creation of new spaces of consumption, such as trendy restaurants and food retail, has helped cities rebrand low-income communities as cultural destinations of leisure and tourism. In cities around the US, these processes often overlap, converting poorer neighborhoods into places more desirable for the middle-class. My dissertation research examines the social and historical forces that have given rise to these twin processes in Miami's poorest neighborhood, Overtown, a historically Black community on the cusp of rapidly encroaching gentrification.

My project incorporates a mix of methods from urban geography, anthropology, and the emerging geohumanities, including geospatial mapping, historical analysis, participatory observation, and in-depth interviews. In triangulating these methods, I first unearth Overtown's vibrant food environment during Jim Crow segregation and then trace its decline through urban renewal, expressway construction, and public divestment, 
focusing particularly on the dismantling of Black food businesses. I also investigate the spatial politics of recent urban agriculture projects and community redevelopment practices, the latter of which aim to remake Overtown as a cultural dining and entertainment district in the image of its former heydays.

This research is theoretically informed by and contributes to work on urban foodscapes, urban geographies of race, and African American foodways. Based on my empirical findings, I argue that redevelopment practices in Overtown are undermining networks of social and economic interdependency in the existing foodscape, effectively reproducing the spatial and racial urbicide once delivered by more overt forms of racism. By linking place-based racial histories to the production of inequitable urban food systems, this research reveals the underlying geographies of struggle and dispossession that have shaped the production of both food deserts and gentrifying foodie districts. 


\section{TABLE OF CONTENTS}

CHAPTER

PAGE

I. GEOGRAPHIES OF RACE, FOOD, AND URBAN DEVELOPMENT ....................1

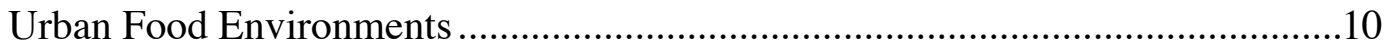

The Racialization of Urban Space ...................................................................17

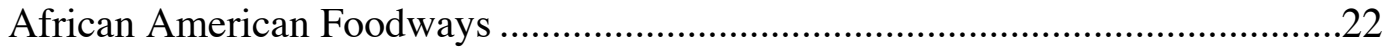

Investigating Food, Race, and Redevelopment in Overtown .............................26

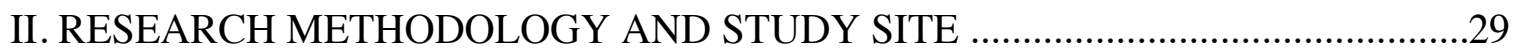

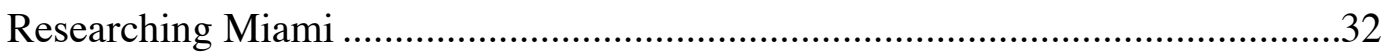

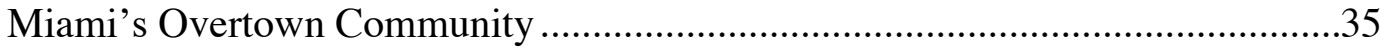

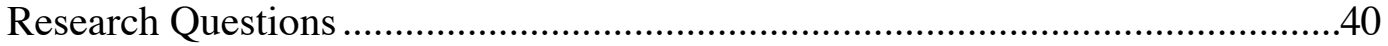

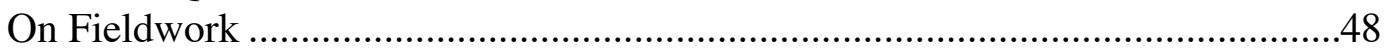

III. THE VEINS THAT FED THE PEOPLE: FOOD, ENTREPRENEURSHIP, AND

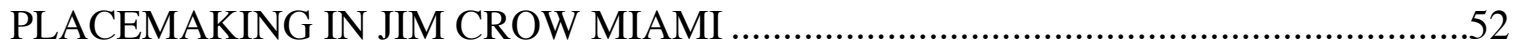

The Caribbean Making of the Magic City ...........................................................53

The Double Standard of the Color Line .............................................................56

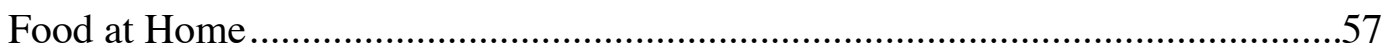

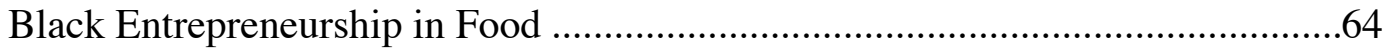

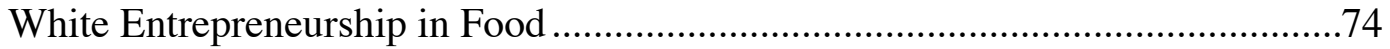

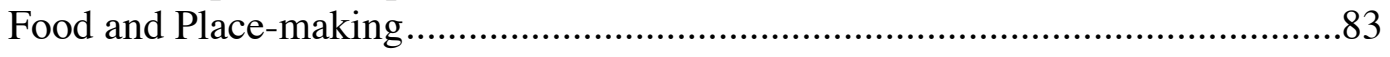

IV. MOM AND POP STORES DON'T HAVE NOTHIN' ON THE BIG STORES:

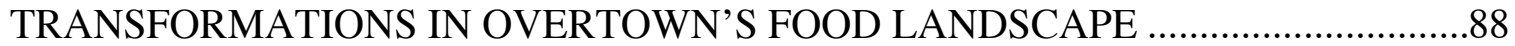

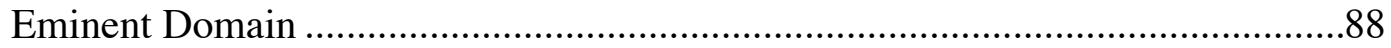

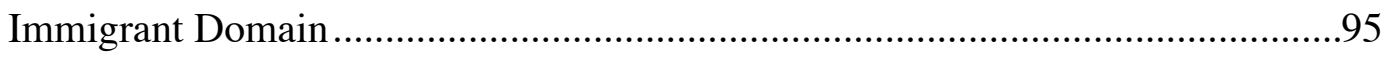

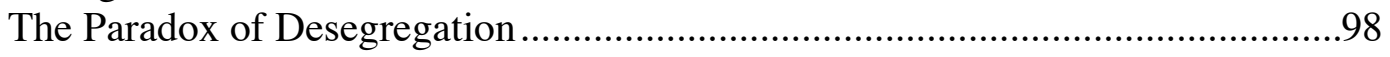

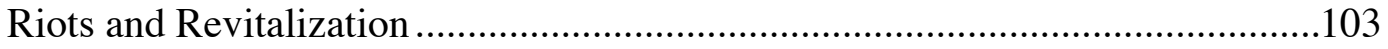

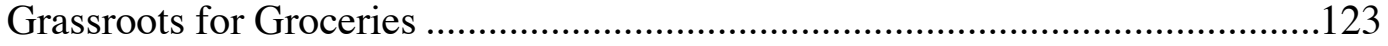

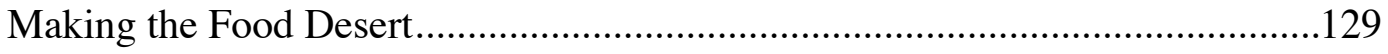

V... NOT BE SO QUICK TO PUT BUILDINGS IN THOSE SPACES:

THE SPATIAL POLITICS OF THE ROOTS IN THE CITY GARDEN .....................132

The Spatial Politics of Urban Agriculture .......................................................135

Neoliberalism and Urban Development in the World City .............................136

Laying Down Roots ..............................................................................140

From Community Garden to Commodity Crop ..............................................148

Doing Inner City Space Differently .............................................................153 
VI. OVERTOWN IS GONNA BE THE PLACE TO BE: SHIFTING FOODSCAPES

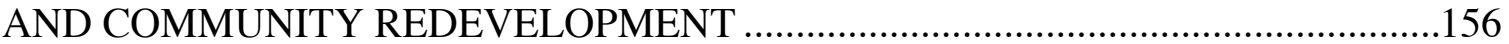

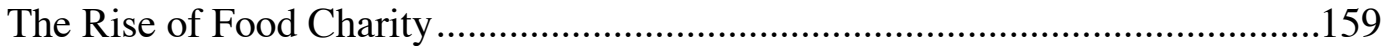

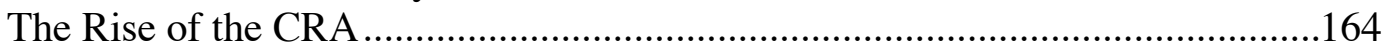

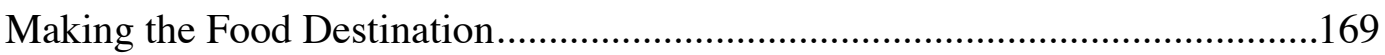

The Wrong Kind of Small Business …………………................................182

Unmaking the Food Desert ………...............................................................196

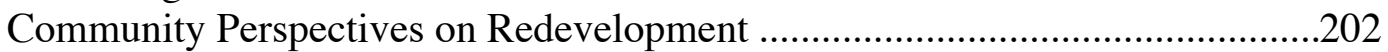

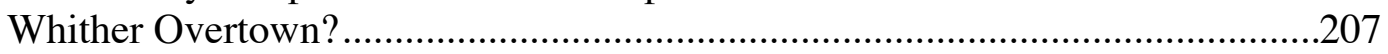

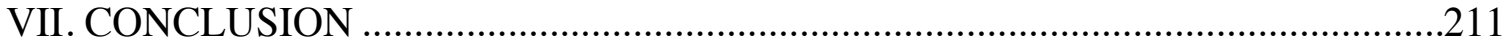

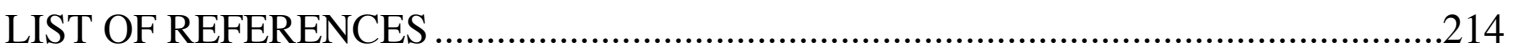

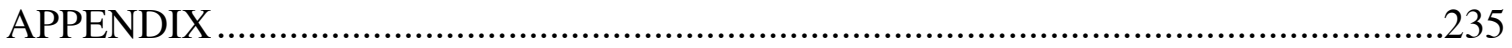

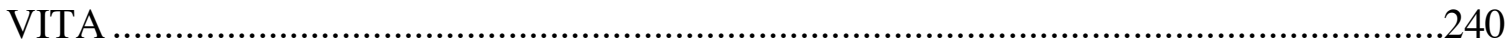




\section{LIST OF FIGURES}

FIGURE

PAGE

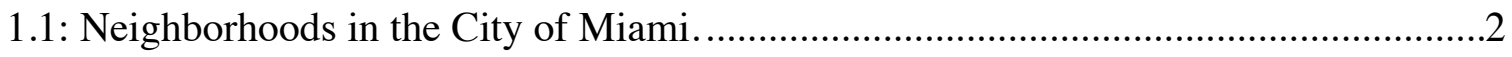

1.2: Map of arrests made by the FEC Railway police force, $2009-2014$..........................5

1.3: Low-income areas in Miami-Dade with low supermarket sales and high rates of

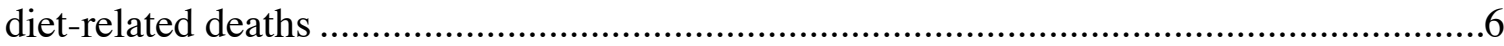

1.4: Low-income areas in the City of Miami with low supermarket sales and high rates

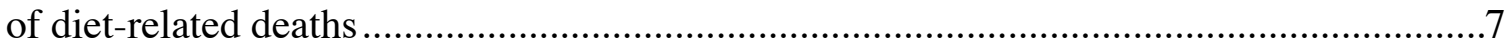

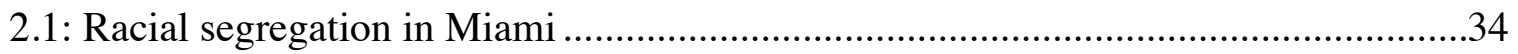

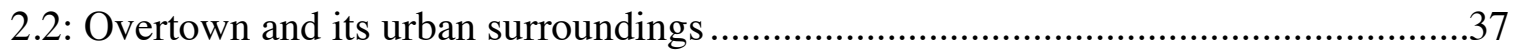

2.3: Listings from 1940 City of Miami business directory ...........................................42

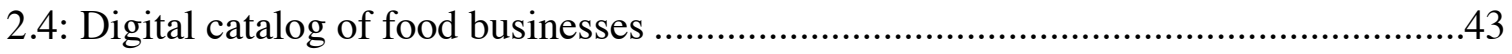

2.5: Aerial photograph map of the Central Negro District ..........................................44

2.6: A section of Colored Town from 1921-1924 Sanborn Fire Insurance map ..............45

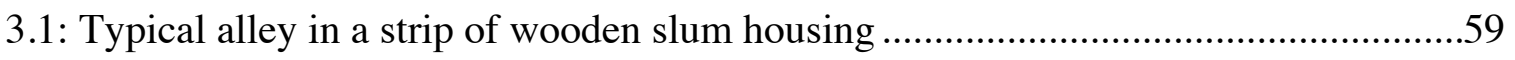

3.2: Home in Colored Town next to a fruit tree...........................................................63

3.3: Woman walking by a business occupied by men in the Central Negro District ........70

3.4: Man selling goods from street cart with Jewish-owned grocery in background ........71

3.5: Engler's advertisement in the Miami News, October 25, 1921 .............................75

3.6: Meat market next to a section of row housing .................................................. 79

3.7: Black- and white-owned food businesses in Colored Town, 1940 ...........................84

4.1: Residential density in the Central Miami Area (Central Negro District) and other neighborhoods

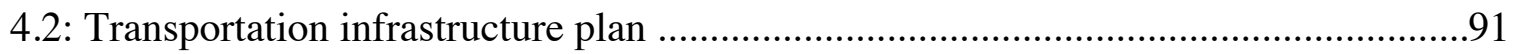


4.3: Locations of food businesses in Overtown following the construction of the I-95/I-395 expressway, 1970 .

4.4: Police stand in front of a looted grocery in Overtown following a 1984 civil disturbance

4.5: A mother and daughter shopping during the grand opening of First Rate Foods.....115

4.6: The Yahweh bus fleet

4.7: First Rate Foods in the Overtown Shopping Plaza after closing down 116

5.1: Roots in the City with downtown condos in the background

5.2: Roots in the City

5.3: One of the former Roots in the City lots

6.1: A corner of Ray's room

6.2: Another corner of Ray's room

6.3: Original SEOPW redevelopment area 166

6.4: Construction of affordable housing in Overtown 175

6.5: Construction of mixed-use development, Plaza at the Lyric, in the planned Historic Overtown Folklife Village.....

6.6: New branding for Overtown by the CRA.

6.7: Chips, milk, and fruit drinks on grocery store shelves

6.8: Eggs, meat, cheese, sandwiches, and other items inside a display case

6.9: Canned, boxed, and bottled food and drinks on grocery shelves 185

6.10: A resident returning from a bus trip to Walmart pushing her groceries

6.11: The Top Value supermarket and Overtown Shopping Plaza

6.12: A City of Miami tweet during the grand opening of Top Value supermarket. .200 


\section{ABBREVIATIONS AND ACRONYMS}

A\&P

CPDC

EDA

FBI

FDOT

FEC

FMPP

GIS

OEDC

NANA

SBA

SEOPW CRA

SNAP

TIF
Great Atlantic and Pacific Tea Company

Civic Partnership and Design Center

Economic Development Administration

Federal Bureau of Investigation

Florida Department of Transportation

Florida East Coast

Farmers Market Promotion Program

Geographic Information Systems

Overtown Economic Development Corporation

Neighbors and Neighbors Association

Small Business Administration

Southeast Overtown/Park West Community Redevelopment

Agency

Supplemental Nutritional Assistance Program

Tax Increment Financing 


\section{GEOGRAPHIES OF FOOD, RACE, AND URBAN DEVELOPMENT}

On a sunny April afternoon in 2014, the Southeast Overtown/Park West

Community Redevelopment Agency (SEOPW CRA) held a groundbreaking event for the $\$ 2.2$ million renovation of the Overtown Shopping Plaza. ${ }^{1}$ The plaza was initially built in the aftermath of the 1980 Miami race riots to stimulate economic development in the Overtown community, a poor historically Black neighborhood within a stone's throw of Miami's towering skyline, but had since fallen into disrepair. More than thirty years later, public officials re-envisioned the plaza playing a crucial role in Overtown's revitalization.

Anchoring the updated shopping plaza would be the Top Value supermarket, a Latino-owned regional chain that would bring Overtown its first supermarket in more than a decade. "I think of all the projects that we're doing, this is the most significant by far," stated Miami commissioner Francis Suarez at a March 2014 SEOPW CRA board meeting. "I think one of the things that in my travels through Overtown that's been glaringly missing, that is in every other community, every other community, regardless of socio-economic background, regardless of ethnicity, et cetera, is a shopping center, a real shopping center" (City of Miami 2014). For Suarez, whose "travels through Overtown" inform his decisions as a SEOPW CRA board member, underdevelopment in the neighborhood was most clearly apparent by the absence of major retailers, such as supermarkets. At the groundbreaking, Keon Hardemon, city commissioner and chairman

\footnotetext{
${ }^{1}$ The SEOPW CRA is the primary agency involved in funding and guiding affordable housing and economic development projects in Overtown.
} 


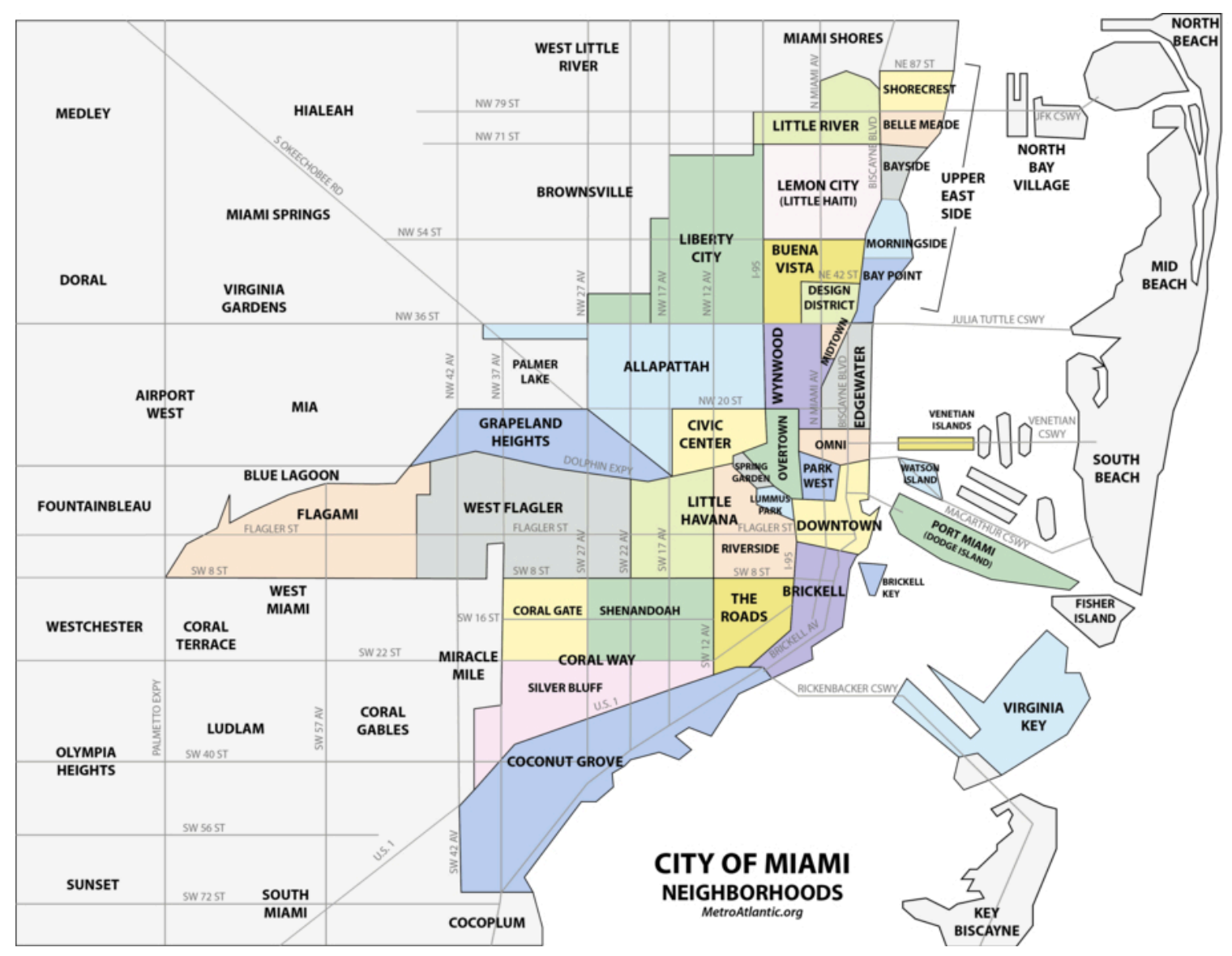

Figure 1.1: Neighborhoods in the City of Miami. Overtown is just northwest of Downtown Miami. Reprinted from MetroAtlantic.org.

of the SEOPW CRA, referred explicitly to the need for a supermarket to the nearly fifty people in attendance:

This project is especially significant because it addresses Overtown's food desert, a complete depletion of affordable grocery stores. In this region, the closest store to a grocer is a convenience store and their merchandise is overpriced, which is unacceptable considering this community's average income. The fact that we're able to renovate this plaza and bring in a commercial business that specializes in food distribution is a tremendous success for Overtown. Residents won't have to shop for groceries at convenience stores.

According to the US Department of Agriculture's definition, food deserts refer to geographic areas inhabited predominantly by low-income residents where access to fresh, 
affordable food is limited due to a lack of supermarkets and full-service groceries (USDA 2009). Across the street from the shopping center groundbreaking stood Overtown's largest food retail store, an unassuming small grocery and meat shop catering mostly to residents arriving on foot and making small purchases. Walk a few blocks in almost any direction and you run into one of twelve or so corner groceries sprinkled throughout the neighborhood, some of which have been serving Overtown for more than forty years. Most of these stores show significant wear and tear, and some are barely hanging on economically. Prices on goods are generally higher than at supermarkets, and the selection for fresh meat, produce, and other nutritious goods can be minimal. In fact, the bulk of sales tend to come from alcohol, snacks, sugary drinks, tobacco, and lottery tickets. Overtown's food retail environment thus bears the typical markers of a food desert, a spatial metaphor popularized in recent years in academic, policy, and food advocacy circles.

Interestingly, although it has been labeled as such, Overtown does not technically meet the USDA's 2009 criteria for qualifying as a low-access food desert. In urban areas, "low access is defined as [living] more than one mile from a supermarket" (Ibid., 21). While up until late 2016 Overtown did not have its own supermarket, three full-service supermarkets located outside its boundaries were still within one mile of its center. The CRA's loose interpretation and flexible application of the food desert concept thus points to a more complex (and unclear) picture of food access among Overtown residents, as absolute Cartesian distances become complicated by both material divisions and social constructions of space. 
For example, Overtown's population is seventy-seven percent “African

American," yet each of the supermarkets are located in majority-white neighborhoods in which African Americans make up less than thirty percent of the population. ${ }^{2}$ Running along the eastern edge of Overtown are the Florida East Coast (FEC) railroad tracks, which once served as the color line during legal segregation. The racialized policing of neighborhood boundaries, however, is not the practice of a distant past. Consider that between 2012 and the first six months of 2014, more than 300 people were arrested (see Figure 1.2 for a map of FEC Railway police force arrests) for illegally crossing the train tracks at the Northwest Seventeenth Street intersection (Ovalle and Sayre 2014), which is the straightest path to the Publix supermarket on Northeast Seventeenth Terrace and Biscayne Boulevard. These arrests accounted for sixty-eight percent of all FEC police force arrests made in Miami-Dade County (Ibid.).

Additionally, despite its proximity to supermarkets, Overtown, like many lowincome, Black communities in the US, is beset with very high rates of food insecurity. Prior to the 2012 redistricting, Overtown was located in the nation's most food insecure congressional district (Food Research and Action Center 2012), which mostly comprised Miami-Dade County’s predominantly Black neighborhoods. ${ }^{3}$ A 2008 study of urban health disparities in Miami found "the most significant indicators of poor health and low socioeconomic status ... in a group of distressed, predominantly Black communities

\footnotetext{
2 The US census category of African American is problematic given the racial and ethnic complexities of Miami's population, which I discuss in chapter two.

${ }^{3}$ While food insecurity is the most common term, the Food Research and Action Center's report uses the synonym "food hardship", which they (along with the Gallup Healthways Well-Being survey) measure with the question, "Have there been times in the past twelve months when you did not have enough money to buy food that you and your family needed?"
} 


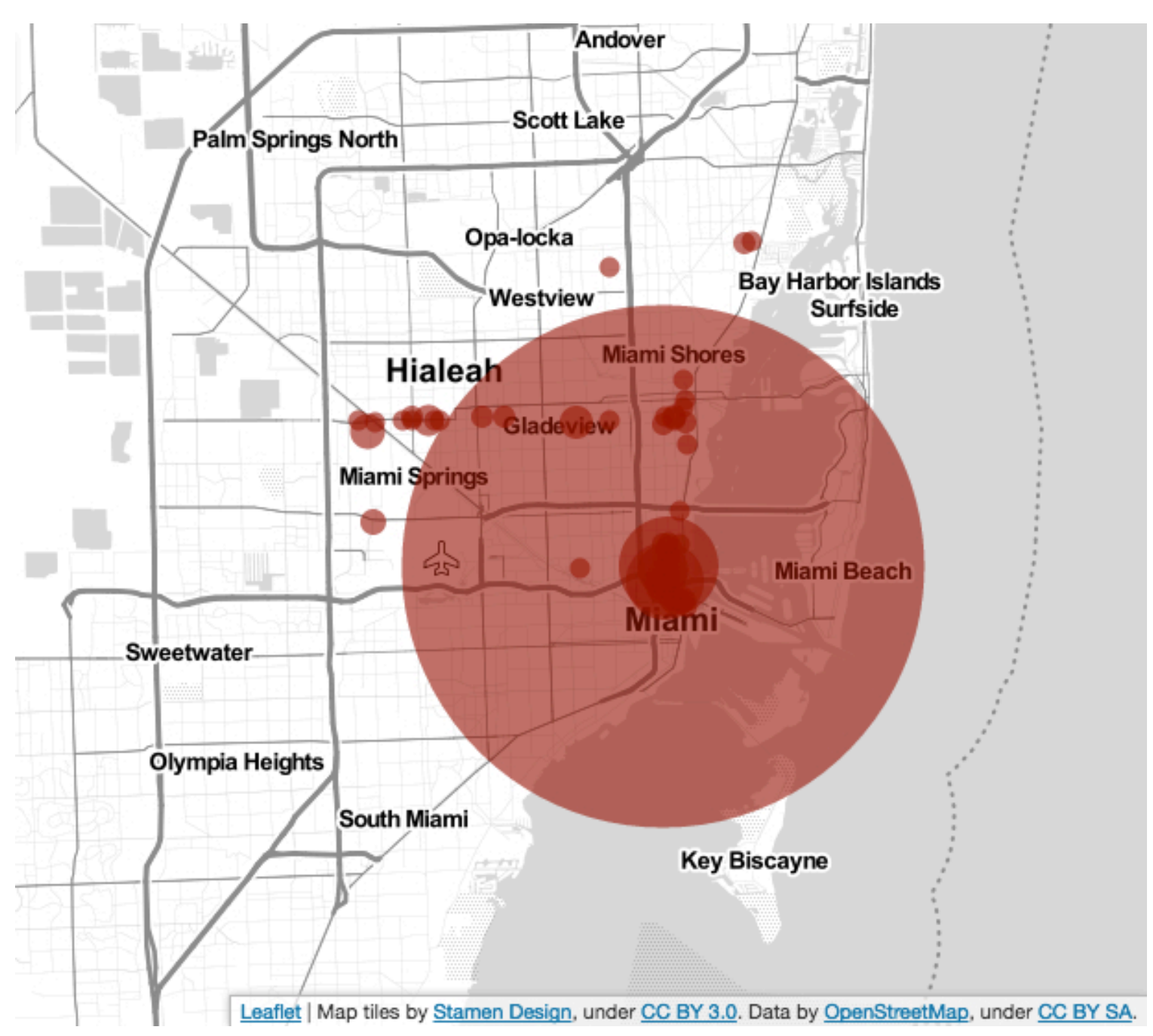

Figure 1.2: Map of arrests made by the FEC Railway police force, 2009-2014. The size of the bubble indicates the number of arrests at each location.

stretching from Overtown to the Broward County border in a corridor along Interstate 95 in north Miami-Dade County" (Brown et al. 2008, 32). Maps from a 2012 report on food access and health in Miami-Dade highlight low-income areas with low supermarket sales and high rates of death from diet-related causes (see Figures 1.3 and 1.4). These areas map neatly onto Overtown, Liberty City, Opalocka, Hialeah, and other African American and Latino communities. In Overtown specifically, rates of diabetes are more than two 

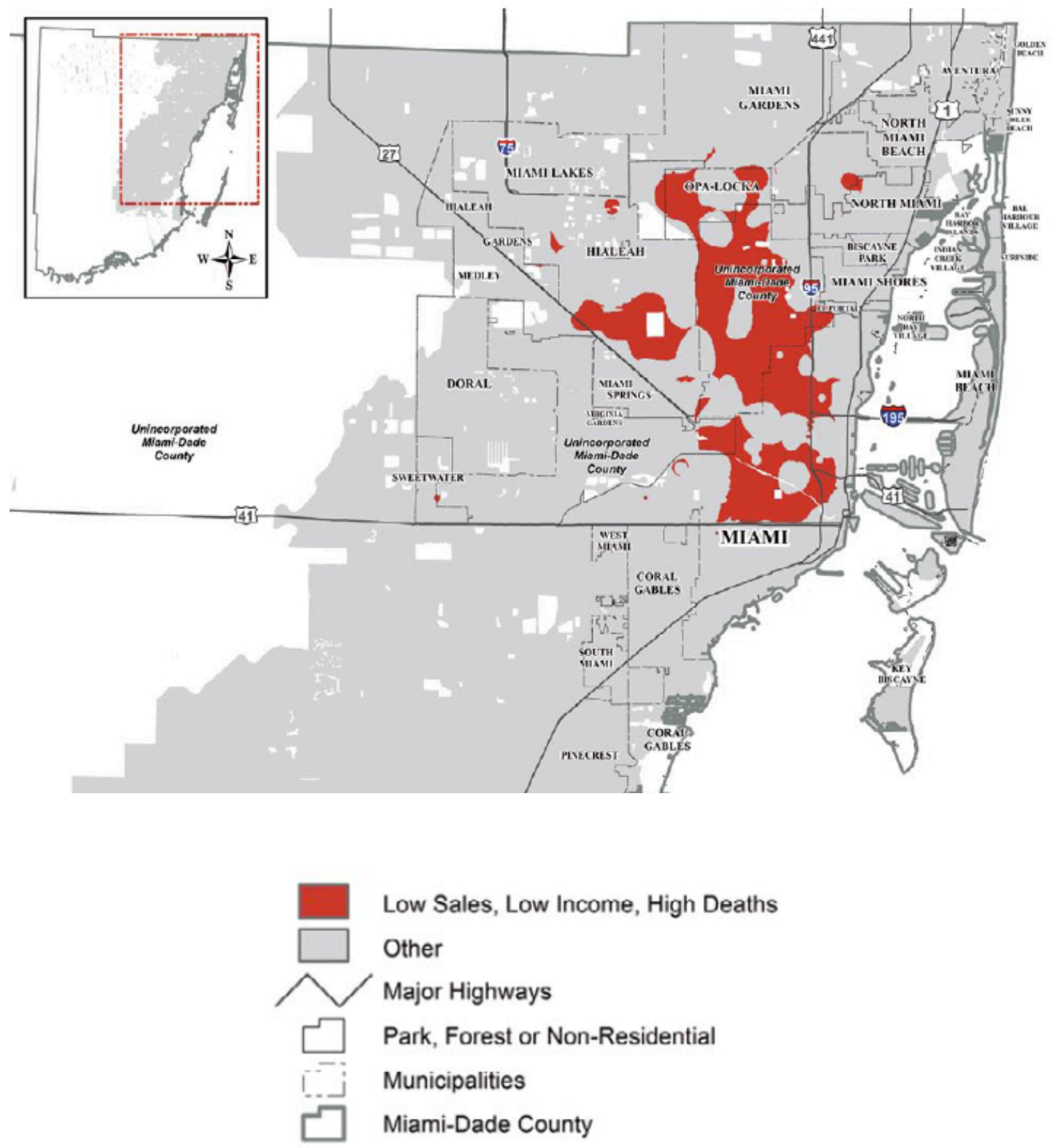

Figure 1.3: Low-income areas in Miami-Dade with low supermarket sales and high rates of diet-related deaths. Reprinted from The Food Trust's 2012 report, "A Healthier Future for Miami-Dade County." 


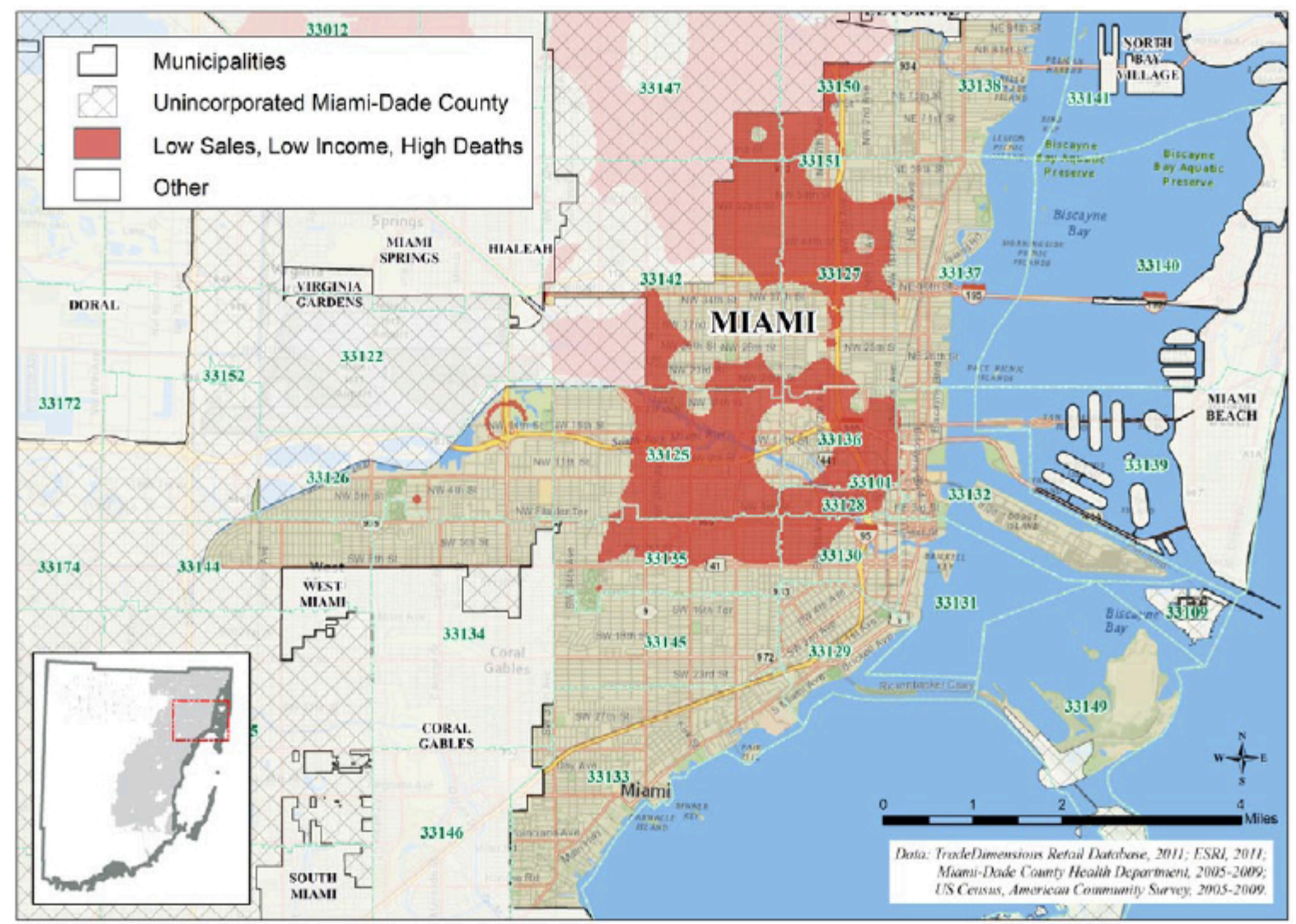

Figure 1.4: Low-income areas in the City of Miami with low supermarket sales and high rates of diet-related deaths. Reprinted from The Food Trust's 2012 report, "A Healthier Future for Miami-Dade County."

and half times higher than in Miami-Dade County overall (Olivieri 2011, 233). Indeed, it is evident that inequalities in the spread of food vulnerability and dietary health outcomes across Miami are not only racial but also spatial.

In light of these material realities, this dissertation does not take issue with the fact that many Overtown residents have difficulty accessing and benefitting from healthy food, a purported symptom of the so-called food desert. Rather I place my concerns with the deployment of the food desert narrative as a discourse of "territorial stigmatization" (Wacquant 2007) that legitimizes public and private intervention in the form of (super)market expansion. Over the years, greater awareness about food deserts, food 
insecurity, and obesity have spurred a range of public and private efforts to attract major food retailers to lower income communities and communities of color. In 2010, First Lady Michelle Obama started the Let's Move campaign with the goal of "eliminating food deserts in seven years" (Let's Move 2010), while the Obama Administration implemented the Healthy Food Financing Initiative, which allocated over \$400 million to incentivize larger food retailers to locate in underserved areas. Although the Top Value supermarket was not incentivized through the Healthy Food Financing Initiative specifically, the $\$ 600,000$ in grants and loans they received from the SEOPW CRA is indicative of "a rising interest in food system governance by public officials in the USA, Canada, and the UK at several levels over the last decade" (Shannon 2014, 248).

In addition to bringing healthy food to food deserts, municipal governments are also facilitating new and revitalized spaces of food consumption as a means of gentrifying low-income areas (Bell and Binnie 2005; Bridge and Dowling 2001; Burnett 2014; Hyra 2008; Wrigley, Guy, and Lowe 2002). In historically Black neighborhoods like New York City's Harlem and Chicago's Bronzeville, trendy “ethnic” restaurants emerge alongside boutique stores and luxury condos, signaling what Derek Hyra (2008) calls "the new urban renewal." Similarly, in the past few years, the SEOPW CRA has allocated millions of dollars in grants for restaurant construction and renovations as part of an effort to create a cultural tourism and entertainment district. In February 2016 the CRA issued a press release, entitled "Overtown: The New Foodies Destination," in which they praised the success of existing Southern food restaurants and formally announced that celebrity chef Marcus Samuelsson, known for his upscale comfort food restaurants in Harlem, submitted a proposal to open a Southern- and Caribbean-inspired restaurant and 
supper club in Overtown. That Overtown can be paradoxically classified as both a "food desert" and the next "foodies destination" suggests that food-related development has become a crucial element in the remaking of poor neighborhoods of color.

This dissertation considers how food helps us understand the relationship between race and the production of space in cities. In particular, I examine Overtown as a site to explore how evolving relationships between food, race, class, and urban development have produced low-income neighborhoods of color as both urban food deserts and the next foodie destinations. As Slocum and Saldanha write in their edited volume, Geographies of Race and Food, "Food ... actively shapes life's spatiality and temporality, bringing humans together and keeping them apart ... That is, certain populations of bodies are structurally recognized as less worthy of sustenance and luxury" $(2013,1)$. While recent scholarship has begun to appreciate the role of food in the co-production of race and space, there still exists a wide theoretical and empirical gap in our understanding of (1) how urban food deserts have emerged as a consequence of racial and spatial struggle, and (2) how food factors into contemporary processes of urban transformation. My project investigates the historical (trans)formation of Overtown's food environments from the early twentieth century up to the current moment, as Overtown experiences the early stages of rapidly encroaching gentrification.

This research sits at the intersection of food studies, urban geography, and Black studies and aims to better connect three currently disjointed literatures: urban food environments, the racialization of urban space, and African American foodways. Below I discuss how these literatures inform and are informed by my work. 


\section{Urban Food Environments}

Urban food studies in the US date back to the 1960s. These early studies reported that inner city residents paid more for food and shopped at smaller groceries with fewer and lower quality options (Ashman et al. 1993; ERS USDA 1968, 1988; MacDonald and Nelson 1991; Marion 1978, 1982; National Commission on Food Marketing 1966). In the last decade or so, research and advocacy on food access has been reinvigorated with the popularization of the "food desert"4 concept, originally coined in the UK.

Concerns about food deserts stem from a social ecology model of public health focused on "how the built and social environment influences individual behaviors like eating and physical exercise” (Ross 2014, 25; see also Egger and Swinburn 1997; Shannon 2013; Swinburn, Egger, and Fezeela 1999). This “supply-side approach” emerged to counter popular media narratives of lazy, uneducated, and undisciplined individuals gorging themselves on junk food and subsequently developing obesity and other diet-related problems (Alkon et al. 2013). In particular, the supply-side approach emphasizes the absence of major food retailers in low-income communities and communities of color, which when replaced with corner stores and fast food restaurants create "obesogenic environments." In the last two decades, a mounting body of research has continued to reveal vast racial, ethnic, and class disparities in the spatial distribution of food retail. According to a systematic review of the food desert literature, eighteen of nineteen studies evidenced that "Geographic areas with a high proportion of low-income or African American residents were underserved by food retailers compared with more

\footnotetext{
${ }^{4}$ The term was supposedly coined by a public housing resident in Scotland to describe the scarcity of healthy food in his neighborhood. It first appeared in print in a 1995 report by the policy sub-group to the Nutrition Task Force Low Income Project Team of the Department of Health (Beaumont et al. 1995).
} 
advantaged areas" (Beaulac, Kristjansson, and Cummins 2009, 3). In these areas, there are fewer supermarkets and large groceries per capita (Alwitt and Donley 1997; Moore and Diez-Roux 2006; Morland et al. 2002; Powell et al. 2007), supermarkets are farther away (Chung and Meyers 1999; Gallagher 2007), food prices are higher (Chung and Meyers 1999), and the food selection is smaller with fewer healthful options (Block and Kouba 2006; Hendrickson et al. 2006; Moore and Diez-Roux 2006; Morland and Filomena 2007; Raja et al. 2008; Zenk et al. 2005). One study of supermarkets nationwide found that African American neighborhoods had just over half the number of supermarkets as white neighborhoods, "with even less availability in urban areas" (Powell et al. 2007, 189). Another study examining supermarket availability across four states found " 4 times more supermarkets located in white neighborhoods compared to Black neighborhoods" (Morland et al. 2002, 23). Together, these studies have established a basis of concern around the racialized and spatialized development of food deserts.

Findings from the food desert literature also coincide with well-published reports on racial disparities in food vulnerability and dietary health outcomes. For instance, Black households experience food insecurity at a rate nearly twice as high as US households overall (Coleman-Jensen et al. 2014). Fifty-six percent of Blacks are measured obese compared with the national average of thirty-five percent (Ogden et al. 2014). However, the relationship between supermarket availability and risk for obesity, among other diet-related outcomes, is at best inconsistent-some studies have found an association (Chen, Jaenicke, and Volpe 2016; Larsen et al. 2015; Thomsen et al. 2015), while others have not (Drewnowski et al. 2012; Ford and Dzewaltowski 2010; Lee 2012). Moreover, studies report that introducing supermarkets to so-called food deserts has little 
to no effect on consumers' fruit and vegetable intake or body mass index (Cummins, Flint, and Matthews 2014; Elbel et al. 2015). In 2016, the USDA even stated: "Some early research found a positive correlation between access to a supermarket ... and diet quality. [...] More recent studies ... show that the effect of food store access on dietary quality may be limited" (Ver Ploeg and Rahkovsky 2016).

That the connection between supermarket availability and dietary health is tenuous reveals an important limitation of the food desert concept. It also raises further questions about using supermarkets as the universal barometer for measuring food access and labeling (and in the process stigmatizing) poor neighborhoods of color as food deserts. Shannon argues that such a heuristic runs the risk of "normalizing middle-class 'foodscapes' as a model for low-income areas" and "close[s] off a more systemic interrogation of both food production systems and processes of urban economic and racial segregation" $(2014,249)$.

To the first point, Raja and colleagues warn that while neighborhoods of color are underserved by supermarkets, "it would be a mistake to overlook the existing extensive network of small grocery stores and their potential role in providing healthful, affordable, and culturally appropriate foods in minority neighborhoods" (Raja et al. 2008, 480). After visiting food stores in three low-income, African American and/or Latino neighborhoods in the San Francisco Bay Area, researchers observed that, despite their geographic unevenness, smaller, full-service retailers "meet many of the criteria for community food security by providing a wide variety of relatively low-cost foods" (Short, Guthman, and Raskin 2007, 352). Sullivan's (2014) work further problematizes the uncritical privileging of supermarkets as the silver bullet solution for food deserts, revealing how a 
supermarket's arrival to a gentrifying neighborhood served white, college-educated residents more than working class minorities. In this vein, my dissertation takes a closer look at the historical and contemporary role of small groceries in provisioning food for low-income residents while examining contemporary efforts to eliminate Overtown's food desert by luring a supermarket.

In line with Shannon's second point, recent scholarship, particularly from geographers, has begun to examine the uneven production of food retail environments within a historical context of structural racism, capital (dis)investment, and spatial inequality (Eisenhauer 2001; Guthman 2011; Kwate 2008; Kurtz 2013; McClintock 2011; Racial Justice Project 2012). Nathan McClintock's work, for instance, examines how deindustrialization, residential development, city planning, and racist mortgage lending combined to produce "capital devaluation within the flatlands [of Oakland] ... and which ultimately created the city's food deserts" $(2011,93)$. Hilda Kurtz, drawing from critical race perspectives that link segregation with a suite of adverse health outcomes, suggests that "critical food environment scholarship should pay more attention to the structural causes of segregation, with a focus on the role of the state in perpetuating institutional racism with broad-based sociospatial effects" (2013, 259). A 2012 report links food deserts to a host of racist policies and practices that segregated American cities, including state-sanctioned redlining in the dispersal of mortgage loans, restrictive housing covenants, discriminatory zoning, the placement of interstate expressways, and the concentration of public housing projects (Racial Justice Project 2012). Thus, as Vincent del Casino asserts, "there is a complex social geography to food deserts that is 
not simply based on proximity and accessibility, but is part and parcel of processes of racialization" $(2015,801)$.

The convergence of state racism - and the socio-spatial organization of cities it fostered - with market forces and major developments in the US agrifood system created highly uneven geographies of food retail. In the early twentieth century, most people purchased groceries from small independent grocers (Eisenhauer 2001). Some selfservice chains, such as Piggly Wiggly and the Great Atlantic \& Pacific Tea Company (A\&P), got their start during this time, but did not command a large percentage of total grocery sales. After the Second World War, industrialization, intensification, and market concentration throughout the US agrifood industry led to the mass production and distribution of food and the concomitant growth of larger food retail chains (Cochrane 1993; Guthman 2011; Winson 2013). Supermarket chains offered food corporations unique opportunities to efficiently market and move their products, including modern refrigeration, lighting, ample shelf space, advertisements, shopping carts, cash registers, and price-marking equipment (Zimmerman 1955). Viewed as safe and profitable investments, supermarkets obtained the necessary capital for growth from banks and investors.

Postwar suburbanization drove upper and middle income residents (particularly whites) away from the urban core, and grocery chains followed, taking advantage of cheap land and an affluent clientele and expanding the number and size of their stores. Location research emerged as a necessary strategy for an increasingly competitive supermarket industry, in which 
the operator delves deeply into every phase of the surrounding community [...] he checks the population, the average age of the residents, whether they are foreign-born or native, the percentage of male to female, their economic level, health data, size of the average family unit, appraises the per capita family earnings to determine what the possible sales per family may be ... [and] looks into other physical factors of the community: whether it is industrial or residential, whether there are more apartment houses or private dwellings. He checks the rents, the number of people who are homeowners, the average size of the apartment... (Ibid., 168, cited in Ross 2014, 36).

In the decade spanning 1950 and 1960, supermarkets doubled their market share, capturing seventy percent of total US grocery sales (Eisenhauer 2001). But as supermarkets chased profits in the proliferating suburbs, "inner city markets, with a few exceptions, were virtually abandoned by leading chains" (Pothukuchi 2005, 234; see also Eisenhauer 2001). Not only was the central city populated with lower income residents, but also lots and retail spaces large enough to house supermarkets were expensive and scarce (Cross 1976). Meanwhile, as the food retail sector became increasingly capitalized and consolidated in the midst of ongoing urban restructuring, the number of neighborhood-embedded, independent food stores dwindled, further marginalizing the urban poor's access to food (Bedore 2013).

The decline of the inner city, however, was not permanent. Since the 1960s and into the present moment, "back to the city" movements to revitalize blighted urban centers have taken over just about every major city in the US. According to critical geographers like Neil Smith, this often entails the funneling of private capital into working-class neighborhoods, the demolition and renovation of older buildings, and an influx of middle-class professionals (Ley 1994; Smith 1987; Zukin 1987). Drawing from Marxist political economy and the spatial ideas of David Harvey, Neil Smith developed 
the "rent gap" theory to explain how capital attempts to close the "disparity between the potential ground rent level and the actual ground rent capitalized under the present land use" $(1979,545)$. Here private investors and developers speculate on the profit potential earned through purchasing cheap property, (re)developing it, and marketing its new use value to more upwardly mobile residents demanding cultural amenities and experiences that reflect middle-class sensibilities, such as loft apartments, trendy or "authentic" restaurants, craft breweries, independent coffee shops, boutique retail stores, and art galleries. Smith (1984) later theorized that gentrification is part of a wider systematic process of uneven geographical development, in which capital overaccumulates in one place and seeks underdeveloped areas as a "spatial fix" (Harvey 1981) for new investment.

Food retail in particular has come to play a key role in the exclusionary remaking and rebranding of inner city neighborhoods, creating desirable spaces of consumption, belonging, and distinction (Bourdieu 1979) for the "new middle class" (Ley 1994) while alienating and sometimes displacing (by driving up rents) longtime lower income residents (see Anguelovski 2015; Bell and Binnie 2005; Bridge and Dowling 2010; Gonzalez and Waley 2012; Sullivan 2014). Some scholars have documented the deliberate partnering of government with supermarkets and other retailers to foster economic development and urban regeneration in inner cities (Lowe 2005; Wrigley, Guy, and Lowe 2002), an example that reflects the rise of public-private partnerships in which the entrepreneurial state works closely with private sector entities to coordinate gentrification (Hackworth and Smith 2001). As Ross writes, "supermarkets are often tied to spatial fix practices that include housing and retail development” $(2014,59)$. 


\section{The Racialization of Urban Space}

Although research on urban food environments is beginning to acknowledge a causal relationship between structural racism and food deserts, it has yet to fully engage with the large body of work on race and space. My project aims to better connect these literatures in an effort to move the politics of food deserts away from simply improving food access in poor communities of color (through supermarkets, farmers markets, community gardens, etc.) and towards recognizing the underlying connections between race and spatial injustice that have created uneven urban food environments.

In the past two decades or so, geographers have placed greater focus on the coproduction of race and space (Anderson 2002; Dwyer and Bressey 2008; Hollander 2006; Jackson 1987; Kobayashi 1990; McKittrick and Woods 2007; Pulido 2000; Neely and Samura 2011), or "how space works to condition the operation of power and the constitution of relational identities" (Delaney 2002,6). Critical geographies of race begin with the premise that race and racial hierarchies are not natural but are ideologically and epistemologically derived from the Enlightenment period, which held the European white male as the pure and fully realized civilized subject. Race justified the colonial project of civilizing dark-skinned others through enslavement and labor exploitation in the service of dominant economic and political interests (Kobayashi and Peake 1994). Over centuries of colonialism and capitalism, race and "racial meanings [have become] embedded in our language, psyche, and social structures" (Pulido 2000, 13), producing "material and mental divisions of bodies into groups according to shifting criteria" (Saldanha 2011, 43). Kobayashi and Peake write, "'Racialization' is ... the process by which racialized groups are identified, given stereotypical characteristics, and coerced into specific living 
conditions, often involving social/spatial segregation and always constituting racialized places. It is one of the most enduring and fundamental means of organizing society" (2000, 393; see also Omi and Winant 1986). Space and race are mutually constitutive in ways akin to Lefebvre's dialectic of social space, in which "the spatial practice of a society secretes that society's space" $(1974,38)$.

Patricia Price (2009) sees this work meeting at a "crossroads" with the wealth of scholarship developed by critical race theorists. For decades, critical race theory has shown us how laws in the US were undergirded by a fundamental and normative “investment in whiteness” (Lipsitz 1998; see also Bell 2000; Harris 1993; West 1993), which had profound spatial and scalar implications in coordinating processes of inclusion and exclusion (Lopez 1997; Delgado and Stefancic 2000). Race and the law converged to create property out of Black bodies for white slaveholders for 245 years. In US law, "the institution of slavery, lying at the very core of economic relations, was bound up with the idea of property" (Harris 1993, 1718). It "constructed 'whiteness' as an objective fact," laying a foundation for social and economic hegemony in which "White identity conferred tangible and economically valuable benefits" (Harris 1993, 1726, 1730). Blacks did not benefit nearly as much as whites did from accessing the 270 million acres of land distributed under the Homestead Acts, a law some forty-six million whites in the US today can trace their family wealth to (Shapiro 2004). In postemancipation urban America, Jim Crow laws and restrictive covenants functioned to imbue homogenously white neighborhoods with economic value. The 1934 Federal Housing Act doled out home mortgages strictly and systematically on the basis of an area's racial composition (neighborhoods with even a single Black resident were 
"redlined" and received the lowest grade), an overtly racist practice that continued into the 1970s (Connolly 2014; Hirsch 1983; Sugrue 2005). These laws and practices, among others, not only created a racial system of advantages and disadvantages for whites and blacks, respectively, but carved it into geographical space, with its patterns most pronounced in cities. Even after civil rights laws dismantled legal segregation and discriminatory practices, the racial wealth gap had been locked in. In the latter half of the twentieth century, economic and racial segregation remained spatially entrenched through interrelated processes of white and middle-class black flight from city centers, suburbanization, and urban sprawl that concentrated poverty within inner city neighborhoods (Massey and Denton 1993; Squires and Kubrin 2005). Today, seventy percent of Blacks and Latinos live in central-city neighborhoods compared with twenty percent of whites. We can therefore begin to see the significant role that race has played in the production of urban space and urban inequalities.

For Lipsitz, spatial inequalities are predicated on a "white spatial imaginary" that “idealizes 'pure' and homogenous spaces, controlled environments, and predictable patterns of design and behavior. It seeks to hide problems rather than solve them.... The suburb is not only an engine of self-interest, but also a place that has come to be imbued with a particular moral value consistent with deeply rooted historical ideals and illusions" (2010,29). The suburbs were built through white desires for spatial and racial purity as well as physical and ideological distance from the messy problems of the Black- and Brown-inhabited inner city. The separation of suburbs from inner cities and industrial zones in the post-war period created a dichotomous socio-spatial structure of cities. Racial space (Neely and Samura 2011) differentially shapes opportunities and life 
circumstances, both throughout the life course and over multiple generations (Squires and Kubrin 2005). "Living in segregated inner-city neighborhoods," Lipsitz argues, "imposes the equivalent of a racial tax on people of color. One important way in which this "tax" is imposed is on the health and well being of Black bodies. The racial wealth gap is also a racial health gap" $(2011,7)$. Black and Brown neighborhoods are disproportionately exposed to toxic waste dumps, incinerators, lead-based paint, and air pollutants from freeways and factories (Bullard 1996; Pulido 2000), located further from employment opportunities (McLafferty and Preston 1992; Wilson 1987, 1996), supermarkets (as discussed earlier), public parks, and hospitals and other medical facilities (Bullard 1996, Dreier et al. 2004, Klinenberg 2002). Low-income Black neighborhoods harbor underfunded public schools and are selectively targeted for surveillance and policing (Browne 2015). Williams and Collins write, "black:white ratios of mortality from coronary heart disease, cancer, diabetes, and cirrhosis of the liver were larger in the 1990s than in 1950" $(2001,405)$. Thus for Ruthie Gilmore, while "race has no essence, racism does," which, drawing from Stuart Hall (1992), she argues results in "fatal powerdifference couplings," or "a death-dealing displacement of difference" $(2002,16$, emphasis original). These examples highlight how racial/ethnic divisions enter into bifurcated realms of biopolitics and governmentality (Foucault 2008), in which different racial groups are differentially subject to spatial enclosures of disciplinary and regulatory power by a racial state (Goldberg 2002).

New theoretical developments in the growing subfield of Black geographies offer a framework for tracing the production of urban racial space back to its plantation origins. Both Woods $(1998,2007)$ and McKittrick $(2011,2013)$ view the plantation as the 
initial colonial site of production from which modern racial capitalism was born. The plantation produced profit through enacting systematic forms of racial/spatial violence and constraint. Through routinized practices (and spectacles) of surveillance, brutality, and confinement, McKittrick argues that the colonial plantation created the blueprint for stamping out a "black sense of place." She writes:

I am not claiming that the plantation and contemporary geographies in the Americas are indistinguishable or identical. Rather I am positioning the plantation as a very meaningful geographic prototype that not only housed and normalized (vis-à-vis enforced placelessness) racial violence in the Americas but also naturalized a plantation logic that anticipated (but did not twin) the empirical decay and death of a very complex black sense of place. $(2011,951)$

McKittrick links the plantation logic to systemic forms of urbicide, or multifaceted and interlocking systems of economic deprivation and racial violence in cities, "wherein the process of uneven development calcifies the seemingly natural links between blackness, underdevelopment, poverty, and place within differing global contexts" (Ibid., 951). The two-fold racialization of space and spatialization of race enacted by the capitalist state creates what Achille Mbembe calls "death-worlds, new and unique forms of social existence in which vast populations are subjected to conditions of life conferring upon them the status of living dead" (2003, 40, emphasis original). It is therefore no mere accident that food deserts and food vulnerabilities often map neatly onto low-income communities of color. Rather the making of "death-worlds" under racial capitalism entails a somewhat predictable structuring of (dis)connections between racialized bodies and the things necessary to sustain healthy human life.

Aside from theorizing the racialized production of space, Black geographies also offer a heuristic for making visible the ways in which place and space is produced 
through Black counter-geographies of resistance and struggle. McKittrick and Woods write, "Often hidden from view, socially distanced from what Audre Lorde calls 'a mythical norm,' seemingly lacking enlightenment and positivist modes of knowledge while also being rendered conspicuous 'objects-in-place,' black histories, bodies, and experiences disrupt and underwrite human geographies" (2007, 4). Black geographies and forms of place-making defy singular ontologies of race and space predicated on enclosure, segregation, displacement, and erasure, instead imagining and inciting alternative politics of place. For Lipsitz, a Black spatial imaginary "counters hostile privatism and defensive localism with democratic and inclusive ideals," creatively cultivating an oppositional spatial consciousness through a range of expressive modes and practices $(2010,13)$.

\section{African American Foodways}

Though the two literatures are distinct - and disconnected - the aims of African American foodways scholarship are completely in line with the intellectual project of Black geographies and hold much promise for studying urban food environments from the vantage point of African American people. Research on African American foodways originated with the Federal Writers' Project under the New Deal in the 1930s, but only in the last decade has it blossomed into its own mature subfield within the interdisciplinary umbrellas of African American studies and food studies. This body of work explores intersections of food, culture, history, and power in African American life. Yet despite its explicit focus on African Americans and food, it remains almost wholly disconnected 
from the literature on food deserts. One goal of my project aims to better connect these separate intellectual areas.

One way to do this is to situate the contemporary food desert issue within the historical arc of African Americans' relationships with the food system, which of course began through plantation slavery. The food desert is not entirely new. Rather it is a permutation of a white supremacist system that over centuries has been built to dispossess Black people of their control over food. Acknowledging and taking seriously the long history of oppressive conditions under which African Americans have learned to cultivate, sell, acquire, prepare, share, and eat food shifts our approach from gazing upon food deserts from an assumed objective, "god's eye" position towards a more grounded and caring interest in the ways in which people actually live in places where access to quality nutrition can be very challenging. As Anne Bower writes in the edited volume African American Foodways, "In the case of Africans and African Americans, the study of foodways enlarges respect for the way a people, so egregiously oppressed, have miraculously managed to hold on to certain traditions from their West African origins yet have adapted and evolved various customs ... contributing hugely to this strange patchwork we call American society" $(2007,8)$.

African American food studies offers a way forward. A major theme of African American food studies focuses on threading the historical development of African American food practices across a variety of diasporic contexts and transformations (Hall 2007; Harris 2011; Opie 2010; Yentsch 2007). Frederick Douglass Opie (2010), for instance, traces the origins and evolution of "soul food," starting with West African spirituality and folk culture and moving through colonialism, slavery, segregation, the 
civil rights and Black power movements, and more recent health and nutrition movements in the African American community, such as those inspired by the Nation of Islam. Similarly, Harris (2011) explores African American culinary history through a personal journey that takes her to West African markets, former slave quarters in Senegal, several colonial settlements along the US eastern seaboard, rural towns in the US South, and urban centers of Black America. This historical approach lays a foundation for situating food practices in urban African American neighborhoods within the diasporic histories that shape people's complex and evolving relationships with food. In addition to unearthing food histories, scholars also underscore the creative ways African Americans, especially women, have used food to improve their material conditions and exercise resistance under regimes of patriarchy and racial oppression. In Black Rice (2001), Judith Carney reveals how enslaved Senegambian women not only imported into the Carolinas an entire knowledge system of growing rice in standing water, but shared this knowledge with their oppressors to negotiate their terms of work, which included spending more time in their own gardens and with their families after completing the day's tasks. Williams-Forson (2006) and Sharpless (2010) reveal how in the post-emancipation South, African American women used food, in the marketplace and by cooking in other women's kitchens, to forge new economic opportunities. Harris discusses how Blacks settling into New York City's Harlem during the Great Migration drew from skills acquired through domestic work and day labor in the South to develop small businesses: "Uptown, though, African Americans had a monopoly on street food and made their livings selling the foods they knew best: items that harkened back to the days of enslavement" $(2011,159)$. In the late 1950s, Blacks staged direct action sit-ins at 
white-owned lunch counters throughout the South to publicly challenge segregation. These examples demonstrate the centrality of food to Black struggles for selfdetermination, economic independence, and racial justice.

Lastly, building off methods common in African diaspora studies more broadly, African American food studies centers Black voices in the production of knowledge about food and the meanings it has to Black people. Inspired by Doris Witt's (1999) pioneering book Black Hunger, Psyche A. Williams-Forson aims to untangle the distorted representations and negative associations between Black people and foods (in her case, chicken) propagated by white racist culture that continue to pervade American consciousness. To do so, she sets out "to read African American lives from the perspective of the people and not from the imagery that tried to define them" $(2006,38)$. Along these lines, Chatelain analyzes Black women's use of culinary writing as a means of "resist[ing] dominant notions or 'controlling images' of black women in the kitchen" $(2015,32)$. African American foodways scholarships thus aims to "resist a singular interpretation of black food culture" and instead offer "myriad ways to reflect on the relationship between food habits and the legacy of the peculiar way that race has been constructed in the United States" (Wallach 2015, xxii, xxvi).

Taken together, the burgeoning work on African American food studies offers a radically different way of studying food and race than we see in urban foodscape research, whether it is studies of food deserts or gentrifying "foodie" districts. More than just writing Black people as victims of colonialism, the racial state, and racial capitalism, African American food studies brings their experiences, forms of resistance, and methods 
of creative adaptation to the forefront to understand how food systems have become dialectically shaped through enduring struggle.

Investigating Food, Race, And Redevelopment in Overtown

The bodies of literature synthesized above provide the theoretical foundation for my dissertation research investigating geographies of food, race, and urban (re)development in Miami’s inner city. My project not only brings these currently disjointed literatures together but also addresses several lacunae within them. For one, a wide gap remains in our understanding of the inner city food environments that preexisted food deserts. My project begins to address this gap by comprehensively unearthing the food landscapes of Overtown (then known as Colored Town and later the Central Negro District) during Jim Crow segregation. This endeavor also expands African American foodways scholarship by tracing the transfer and creative improvisation of foodways from rural plantations in the Caribbean and US South to racially segregated urban contexts. Here I focus particularly on the spatial development of Colored Town's robust Black-owned food retail environment as well as the crosscultural exchange of African diasporic food practices.

Secondly, while we know that contemporary food deserts are the outcome of structural racism and uneven geographical development, few studies empirically document how they actually form in place. Of the studies that do exist, such as McClintock's (2011) work in Oakland or Ross's (2014) in Atlanta, they are geographically and sociologically unique. Thus while McClintock (2011) explains Oakland's food deserts as the result of postindustrial capital disinvestment, Miami's 
social and political history presents a rather different set of circumstances for the production of uneven food environments. As such, my work empirically documents how Overtown's rich food environment was undermined and transformed through the collision of several forces, including racial desegregation via urban renewal and expressway construction projects, a rapidly growing and consolidating food retail industry, mass immigration, police brutality, and failed public-private attempts at economic redevelopment.

Third, my research emphasizes how food environments have been actively shaped through historical struggle. Whenever possible, I center personal narratives from residents, food entrepreneurs, and urban gardeners to underscore the various ways in which people resist and creatively adapt to changing neighborhood foodscapes. In line with a Black geographies approach, I do this to move away from a geographic praxis predicated on representing "people of color [as] mere victims of geography" towards one that recognizes them as active agents "engaged in creative processes of world-making" (Hawthorne and Meché 2016). In doing so, I hope to support the making of new knowledges and meanings of place that can better inform both scholarly and political practices of food justice.

Finally, my project considers how food landscapes are not just products of wider processes of urban change but also mediate these processes. There is a dearth of scholarship on the major role food is currently playing in the redevelopment of historically African American inner city neighborhoods. Not only are supermarkets returning to the urban core, but also around the US, a revival of interest in Southern and "soul food" has exploded among urban chefs and middle-class foodies. My project 
examines the role of government in deliberately restructuring the food environment as a community redevelopment strategy.

The dissertation proceeds as follows. In chapter two, I discuss my methodological approach and situate the study site, Overtown, within Miami's historical development. In chapter three, I unearth the hidden foodscapes of segregated Overtown (then known as Colored Town or the Central Negro District) and discuss how food mediated African American place-making and community building in the face of Jim Crow. In chapter four, I trace the transformation of Overtown's food environment from the 1960s, as urban renewal, highway construction, desegregation, and mass immigration dramatically altered conditions for Black progress, through the end of the twentieth century, as Overtown became mired in the spatial politics of civil disturbance and economic redevelopment. In chapter five, I examine the Black-led Roots in the City garden project that emerged in the aftermath of 1980s civil unrest and morphed in the context of large-scale gentrification plans. In chapter six, I investigate how the remaking of food environments has emerged as a key strategy of community redevelopment and highlight the impact it is beginning to have on food access and provision. Finally, in chapter seven, I conclude with a discussion of the study's major findings and offer some lines of departure for linking food movements to other movements for racial justice. 


\section{RESEARCH METHODOLOGY AND STUDY SITE}

My dissertation draws from methods in urban geography, anthropology, and the humanities to develop an interdisciplinary, multi-method approach for researching the making and unmaking of an "urban food desert." I designed this methodology to expand upon and in some ways contrast with traditional ways of studying urban foodscapes. Most food desert studies rely solely on quantitative and remote methods such as GIS to apprehend spatial relationships between food retail and demographic characteristics (see, for example, Block et al. 2004; Gallagher 2007; Raja et al. 2008; Zenk et al. 2005). While helpful in presenting an illustrative snapshot of the number and types food retailers that (do not) exist in a given area, this approach raises more questions than it provides answers.

To begin, studies of food deserts often dehistoricize the landscapes they seek to understand, effectively masking the political economic regimes and social struggles that have historically shaped urban environments. A vast gap exists in our understanding of how foodscapes, especially in low-income communities of color, have changed over time. At the same time, as Ross notes, "few studies approach questions of food access within the context of urban redevelopment and gentrification" or "specifically name gentrification as an urban process that is both mediated by and mediates food access" $(2014,21)$. My project thus aims to situate and analyze Overtown's foodscapes in relation to historical and contemporary processes of urban change.

Secondly, as Shannon argues, mappings of food deserts "present a 'god's eye' view representing food deserts as objective, calculable spaces rather than as sites of everyday practices” (2014, 255; see also de Certeau 1984; Haraway 1998; Scott 1998). 
Here the food desert is assumed to have an overdetermining — and universalizing - effect on food practices. Residents living in food deserts are portrayed as trapped victims without agency in navigating food access. Of course, as Alkon and her colleagues contend based on personal narratives of food access they elicited, "low-income people are neither unthinking dupes of the corporate food system motivated only by appetite, nor overly rational calculators driven only by price, but inhabitants of marginalized yet complex social worlds in which they must actively navigate a variety of barriers to obtain foods they prefer" $(2013,132)$. This claim is affirmed by the work of Cannuscio et al. (2010), who show how community histories and personal experiences shape how lowincome people in Philadelphia navigate and make meaning of their local food environments. They explain, "food access is driven by both objective and subjective forces, all contributing to urban foodways, including affordability, transportation options, social harmony/discord between shoppers and shopkeepers, (mis)match between consumer expectations/wishes and available goods, and perceived safety of the retail outlet (and the route there)" (2010, 388). As such, Miewald and McCann deploy the term "foodscape" to get at "the relationships that a particular community has with food" rather than the "separate, quantifiable, and mappable attributes (eg existence and number of outlets)" of an urban food system $(2014,540)$.

Informed by these critical approaches to food environment scholarship, my methodology combines qualitative and quantitative methods to investigate relationships between food, race, class, and urban development. I am particularly inspired by the possibilities opened up by the convergence of geography and the humanities, or what has been termed "geohumanities" (Dear et al. 2011) or the "spatial humanities" 
(Bodenhamer, Corrigan, Harris 2010). Geohumanities offers a framework for methodological experimentation in bringing quantitative, qualitative, and visual data together and interpreting them in relation to one another. The emerging field follows upon epistemological traditions in the humanities and critical social sciences that eschew notions of objectivity (Haraway 1988) and theoretical finality, instead triangulating methods to generate new perspectives on space and meanings of place (Bodenhamer et al. 2010, xiii-xiv). Because a central aim of my project is to pierce through the objective veneer of traditional food desert cartographies and examine a "deep history" (Pulido 2015) of food in Miami's inner city, I have turned to the spatial humanities in search of methodological and analytical tools for weaving historical and geospatial data.

I also draw from qualitative approaches common to human geographic research, including ethnographic interviews, textual analysis, and participatory observation (Hay 2010). Conducting interviews, analyzing oral histories, and observing events in the field allowed me to engage with the people who make meaning of place-based social processes. Triangulating these methods helped me to understand how Overtown's landscapes are both constructed and lived and how macro structures and micro processes of life interpenetrate (Herbert 2000). Whenever possible, I underscore personal narratives from residents and food entrepreneurs to illustrate the various ways people experience and creatively adapt to neighborhood change.

Finally, this dissertation research focuses primarily on one central city neighborhood, Miami's Overtown community. Although this methodological decision limits the generalizability of my research, it also illuminates the nuanced process of how a food desert unfolded in a particular place. Overtown is a particularly apt site for 
exploration, one, because of the way food deserts pattern, in Miami and around the US, onto historically low-income and racially segregated neighborhoods, and two, because its food environment is currently shifting in the midst of major revitalization projects. Below I discuss my study site in further detail.

\section{Researching Miami}

The Miami metropolitan area is a beguiling place for researchers because of the many rapid and complex changes it has undergone in its relatively short history. Sandwiched in between the Florida Everglades to the west and Biscayne Bay and the Atlantic Ocean to the east, the Miami area began to transform from a swampy wilderness, inhabited by indigenous cultures like the Tequesta and Seminole, into a massive urban sprawl beginning in the late nineteenth century. Its subtropical climate, coastal location, and expansiveness made it an attractive site for wealthy investors from the northern US. By the early decades of the 1920s, Miami had become the fastest growing US city ever, earning it the nickname, the "Magic City." In the past century, the Miami region has grown to become the eighth largest metropolitan area in the US. Miami is also recognized as a world city with its large economy driven by real estate development and global finance, trade, and tourism.

Miami's sociocultural landscape has been uniquely shaped by immigration patterns over the last century or so, particularly from Latin America and the Caribbean. A watershed moment in Miami's immigration history began in 1959, when thousands of elite Cubans fled their homeland after Fidel Castro assumed power. In the context of the Cold War, exiles from communist Cuba received massive, unprecedented federal 
financial aid and with these resources quickly developed prosperous ethnic enclaves in Miami and networks of trade with Latin America (Portes and Stepick 1993). Since then, several waves of immigration from Latin America and the Caribbean, particularly from Cuba, Colombia, Haiti, have led to Miami having the highest percentage (fifty-eight percent) of foreign-born residents of any US city. Latinos make up sixty-five percent of the population across Miami-Dade and seventy percent of residents in the City of Miami (US Census 2010).

Yet while Miami is in many ways the "gateway to the Americas," its social geography has also been profoundly shaped by the US racial caste system. The patterns of immigration that began to unfold in the latter half of the twentieth century overlaid onto a region governed for decades by Jim Crow laws and white supremacy. Blacks, who make up about nineteen percent of residents in both Miami and Miami-Dade County, remain largely segregated from whiter, middle class Latino and Euro-American communities. In 2010, the Miami Metro area ranked seventh in the nation in terms of Black-White segregation (Logan and Stults 2010). In 2003, the Brookings Institution reported Black-Hispanic segregation in Miami to be the "third highest among all US cities" (Brookings Institution Center on Urban and Metropolitan Policy 2003). The Weldon Cooper Center for Public Service's racial dot map lays bare Miami’s highly segregated racial landscape (see Figure 2.1). Contiguous zones stretching from eastern Little Havana up to North Miami Beach contain Miami Dade's poorest Latino, African American, and Haitian enclaves, while the rest of the county primarily consists of a mix of "white" Latinos and Euro-Americans with a small percentage of upper and middle income people of color. 


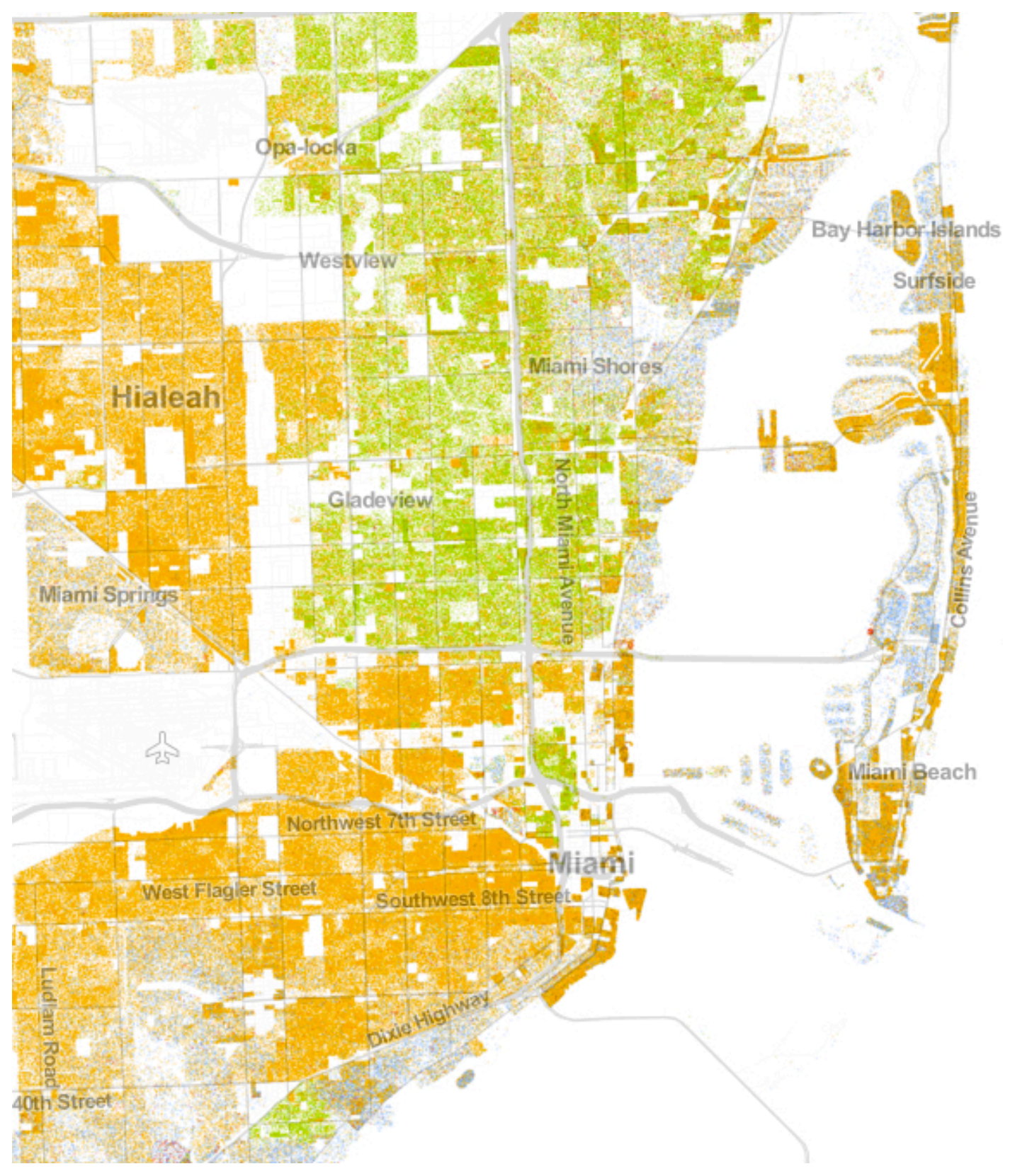

2010 Census Block Data

1 Dot $=1$ Person

White

Black

Asian

- Hispanic

Other Race / Native

Figure 2.1: Racial segregation in Miami. Accessed from the University of Virginia's Weldon Cooper Center for Public Service. 
It is important to note, however, that ideological constructions and categories of race and ethnicity in the US do not often match with the ways immigrants in Miami conceptualize their social identity. For instance, dark-skinned Cubans, Puerto Ricans, and Dominicans often learn they are designated "Black" according to the US binary racial system, which conflicts with how race is constructed their homeland (Candelario 2007; Duany 1998). Moreover, US census categories of "Latino" and "Hispanic" are problematic in the way they are simultaneously racialized (constructed as non-white) and deracialized (rendering Black Latinos invisible).

Finally, within Miami's racial and ethnic mosaic (as opposed to a melting pot) lie deep economic inequalities. Miami is the most income unequal city in the US (Bloomberg 2016). Despite the region's economic boom from 2000 to 2008, during which time Miami tripled its condominium inventory, the post-recession era has been marked by rising inequalities and shrinking opportunities for the vast majority of residents, especially those at the bottom. According to a recent report by FIU's Metropolitan Center, “Only [Miami-Dade] County's top 5\% of all households gained income from 2008 to 2014" (2016, ii), with most job creation taking place in lower wage service-based jobs. Meanwhile, the county's poverty rate is thirty-three percent higher than the national poverty rate. Miami’s twentieth percentile earns about $\$ 11$ a day, which trails only Detroit in the US.

\section{Miami's Overtown Community}

The primary focus of this research is Miami's Overtown community, a roughly .75 square mile section of the city located just northwest of the downtown district (see 
Figure 2.2). The neighborhood dates back to the founding of the City of Miami in 1896. It was originally designated for many of the African American and Afro-Caribbean laborers who built the Florida East Coast railroad and most of the city's initial structures. In its early years, Overtown grew into a vibrant community of upwards of 40,000 residents and was often referred to as the "Harlem of the South" (Mohl 1993; Dunn 1997). However, as a result of postwar era urban renewal projects, middle income Black flight, and the construction of an interstate expressway through the center of the neighborhood, much of Overtown's population was displaced, with most of those that remained falling into deep poverty (Dluhy, Revell, and Wong 2002).

Today, Overtown remains Miami’s most impoverished neighborhood and suffers from poor health outcomes (Brown et al. 2008), unemployment, crime, substance abuse, and physical decay. More than half of Overtown's 8,400 residents live below the poverty threshold. The average annual household income amounts to less than $\$ 15,000$, and ninety percent of residents rent their homes. As mentioned earlier, in 2011 Overtown comprised a portion of the country's most food insecure congressional district (Food Research and Action Center 2012). Death rates for diabetes are three times higher than in Miami-Dade overall (Olivieri 2011). The only employers in Overtown are the Top Value grocery, a regional chain that just recently opened in October of 2016, and a handful of restaurants, small groceries, barber shops, and hair salons. Thus most employed residents leave their community for work, usually in construction, in the low-wage service sector, or hauling cargo at the Port of Miami. Additionally, because of the structural lack of opportunity, many residents have become entangled in various networks of economic 


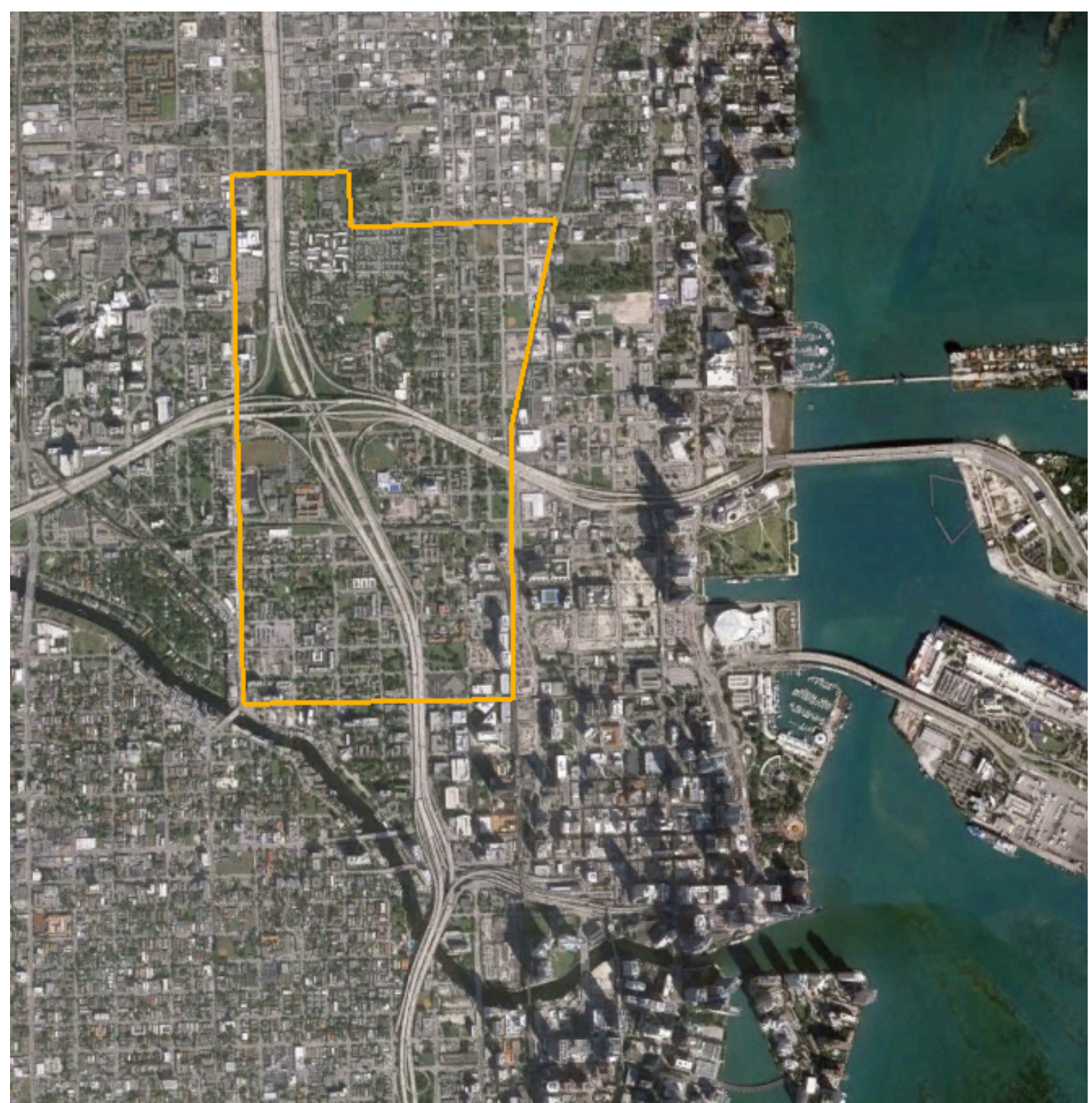

Figure 2.2: Overtown (bordered in orange) and its urban surroundings. 2016 satellite imagery from Google Earth.

informality, which include exchanges around illicit and prescription drugs, sex, food, transit cards, clothing, and household items.

Meanwhile, Overtown is on the verge of major transformation. Long referred to as the "hole in the doughnut," Overtown sits in the center and shadow of Miami's 
prosperity, abutting wealth and capital investment in all directions. To the north, a district of art galleries, restaurants, boutique retail shops, craft breweries, and street murals in the recently gentrified Wynwood neighborhood has become a world tourist destination. Less than a mile from Overtown's eastern edge lies Biscayne Bay and along it runs a strip of high-rise condominiums, luxury hotels, waterfront parks, museums, performance centers, and restaurants. Two blocks closer to Overtown, the Miami Worldcenter, a twenty-seven acre retail, hospitality, and condo mega-complex, is currently undergoing development. South of Overtown are most of the city's government buildings, the financial district, and the Miami River, whose riverside parcels are undergoing major economic development in the form of higher end restaurants and retail centers. And to the west of Overtown, lies a cluster of major hospitals and research centers.

In the last few years, Overtown has begun to undergo capital-intensive redevelopment, facilitated primarily by the SEOPW CRA, which oversees and allocates funding for community revitalization projects. In 2016, with the assistance of \$34 million in CRA funding, Overtown saw the completion of its first ever mid-rise residential towers. The CRA is currently spending $\$ 35$ million for the rehabilitation and renovation of more than 400 existing apartment units. The CRA spent $\$ 15$ million on the redevelopment of a local park. Inside Overtown's eastern edge, MiamiCentral, a multimodal transit station that will link Miami's Metrorail, South Florida's Tri-rail, and a new high-speed train to central Florida, is currently under construction. Adjacent to the transit hub, a mixed-use building is under construction on CRA-provided land, subsidized with 17.5 million CRA dollars. The ground floor will house a Publix supermarket and other commercial spaces. The CRA has also poured millions into the restoration of historic and 
long-established buildings and businesses, which together will comprise the major dining and entertainment destinations of the planned Historic Overtown Folk Life Village. In 2014, a Miami Beach-based developer purchased \$17 million worth of vacant lots and apartment complexes within the Folk Life Village, making him the neighborhood's second largest landholder next to the CRA. Soccer star David Beckham and his investor partners purchased land at the southwestern corner of Overtown with plans to develop a soccer stadium.

Along with these changes to the physical environment, Overtown is shifting demographically, its white Latino population growing as cheap (but increasing) rents, good access to public transportation, and a prime central city location have made the area more attractive to outsiders. According to the 2010 US Census, African Americans make up seventy-seven percent, whites sixteen percent, and Hispanics (both Black and white) twenty-three percent of the population in the census blocks encompassing Overtown (US Census 2010). Incoming Latinos are not necessarily integrating throughout the community, instead tending to inhabit their own enclaves, mostly at the neighborhood's edges or along the high-traffic, and presumably safer, $3^{\text {rd }}$ Avenue commercial corridor. At the same time, many of Overtown's Black residents are becoming displaced, as building condemnations and rising rents outpace the construction of new "affordable" housing. In fact, even newly built affordable housing developments are well out of financial reach from the majority of residents. It is within this context that I conducted my dissertation research. 
Research Questions

\section{Research Question \#1: What geographies of food procurement and provision existed in Overtown during Jim Crow segregation?}

My interest in examining Overtown's early food environments was initially piqued upon discovering transcripts from the Tell the Story oral history collection. I accessed transcriptions from this collection digitally from the University of Florida's (UF) George A. Smathers Library website, which housed them as a part of their oral history collections through the Samuel Proctor Oral History Program. Recordings of these oral histories exist but were inaccessible throughout the duration of my archival research due to the Black Archives moving to their new location in Overtown. This collection of nearly fifty accounts by former Overtown residents was produced in the late 1990s in collaboration between the Black Archives History and Research Foundation of South Florida and researchers at Florida International University (FIU). In reading these rich accounts of everyday life during Overtown's "heydays," it became evident to me that food played a key role in the ways residents created a sense of place and identity and a source of livelihood under Jim Crow segregation. I read carefully through each oral history, coding for themes related to food environment composition, food entrepreneurship, food labor, food shopping practices, cooking practices, food cultivation and gardening, community food spaces, family food practices, the sharing of foodways, and food and identity.

After reading through these personal narratives, I then became interested in mapping Overtown's neighborhood food business environment. I first located City of Miami business directories (see Figure 2.3) at the Miami-Dade Main Public Library and, 
using Microsoft Excel, created a digital catalog (see Figure 2.4) of food establishments (groceries, meat markets, restaurants, bakeries, produce stands, and so on) in and around Overtown (including any outside businesses explicitly mentioned in the oral histories) for the years of 1920,1940, and 1960. Up until 1948, businesses owned by a person of African or Asian descent were marked with a "(c)." This allowed me to understand the significant extent to which whites, both American- and foreign-born, owned and operated food businesses in Overtown's residentially segregated community.

Next, to create a map of Overtown's food business environment, I obtained a digitally archived, high resolution 1952 USDA aerial photograph of Miami from FIU's Maps and Imagery User Services. I cropped a portion of this photograph and georeferenced it onto a digital coordinate system (using ArcGIS 10.x software), creating a base for the map. For my first layer, I highlighted Overtown's historical neighborhood border, which I found in a 1949 slum clearance report (see Figure 2.5). I then imported my digital catalog of food businesses into GIS. My objective here was to overlay these addresses onto the georeferenced photograph. However, because Overtown's historical street network was dramatically altered by the construction of the I-95/395 expressway system during the 1960s, I could not simply geocode addresses using a contemporary address locator. Instead, I used 1921 Sanborn Fire Insurance maps (available through UF's digital collections), which displayed the original street grid and individual building locations, to manually match the location of each address to its corresponding parcel (see Figure 2.6). I then manually geocoded each address, creating a point for each business onto its matched edifice on the photographic base layer. I also implemented a binary color symbology to distinguish those businesses left unmarked from those categorized as 


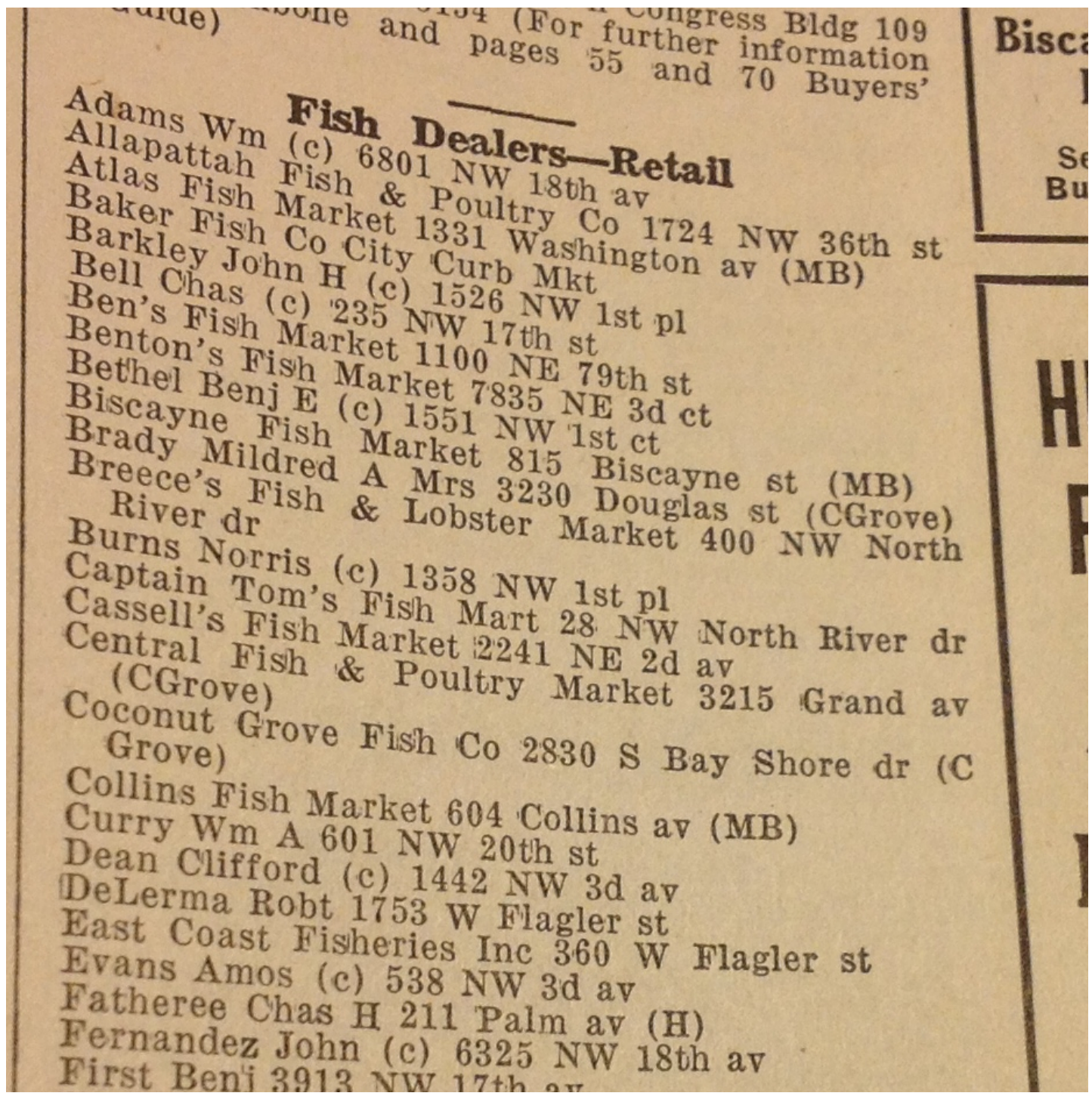

Figure 2.3: Listings from 1940 City of Miami business directory. Accessed from the Miami-Dade Main Library.

"colored" in the city business directories. This resulted in a map featuring the locations of Overtown's extensive food business network (as shown in the next chapter).

Matching names, addresses, business types, and racial assignments from the 1920 and 1940 city business directories with 1920 and 1940 manuscript census records (searchable through Ancestry.com) allowed me to collect more details on the business 


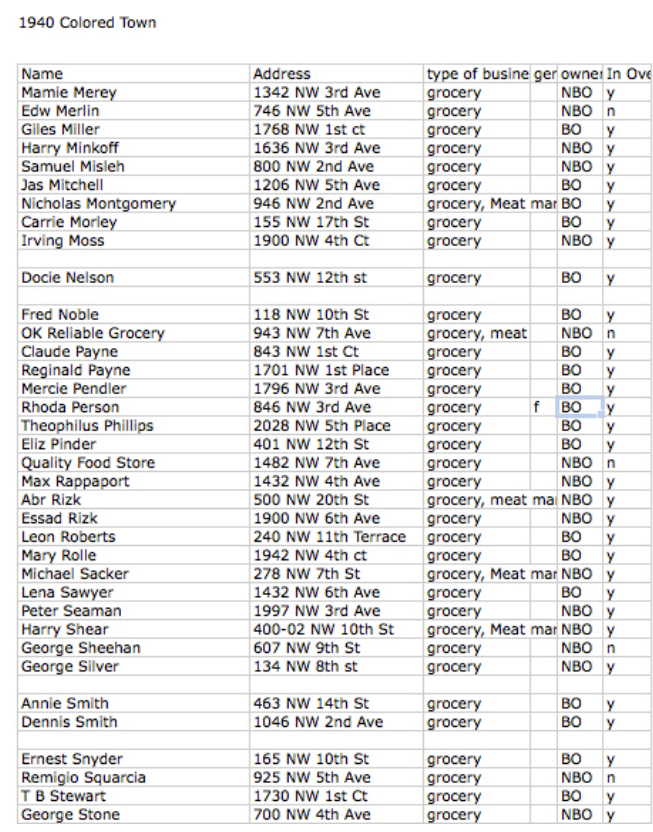

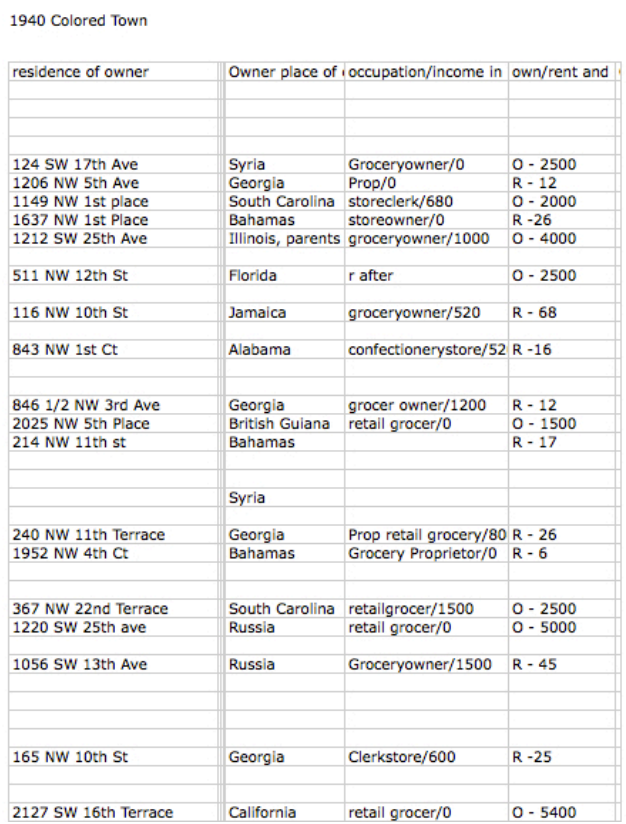

Figure 2.4: Digital catalog of food businesses. Created by author.

owners themselves, including their places of birth, places of residence, household and family structure, home values, monthly rents, and annual incomes. This provided information about the class and ethnic distinctions within Overtown's food business proprietors as well as the often overlapping relationship between home and work (in several cases, food businesses were operated from one's home). I was also able to locate newspaper articles, films, photographs, and other archival materials held at the National Archives, HistoryMiami, the Black Archives, Miami-Dade's Main Library, and the University of Miami (UM) and FIU Library's special collections that further illuminated the role of food in shaping life in Overtown. 


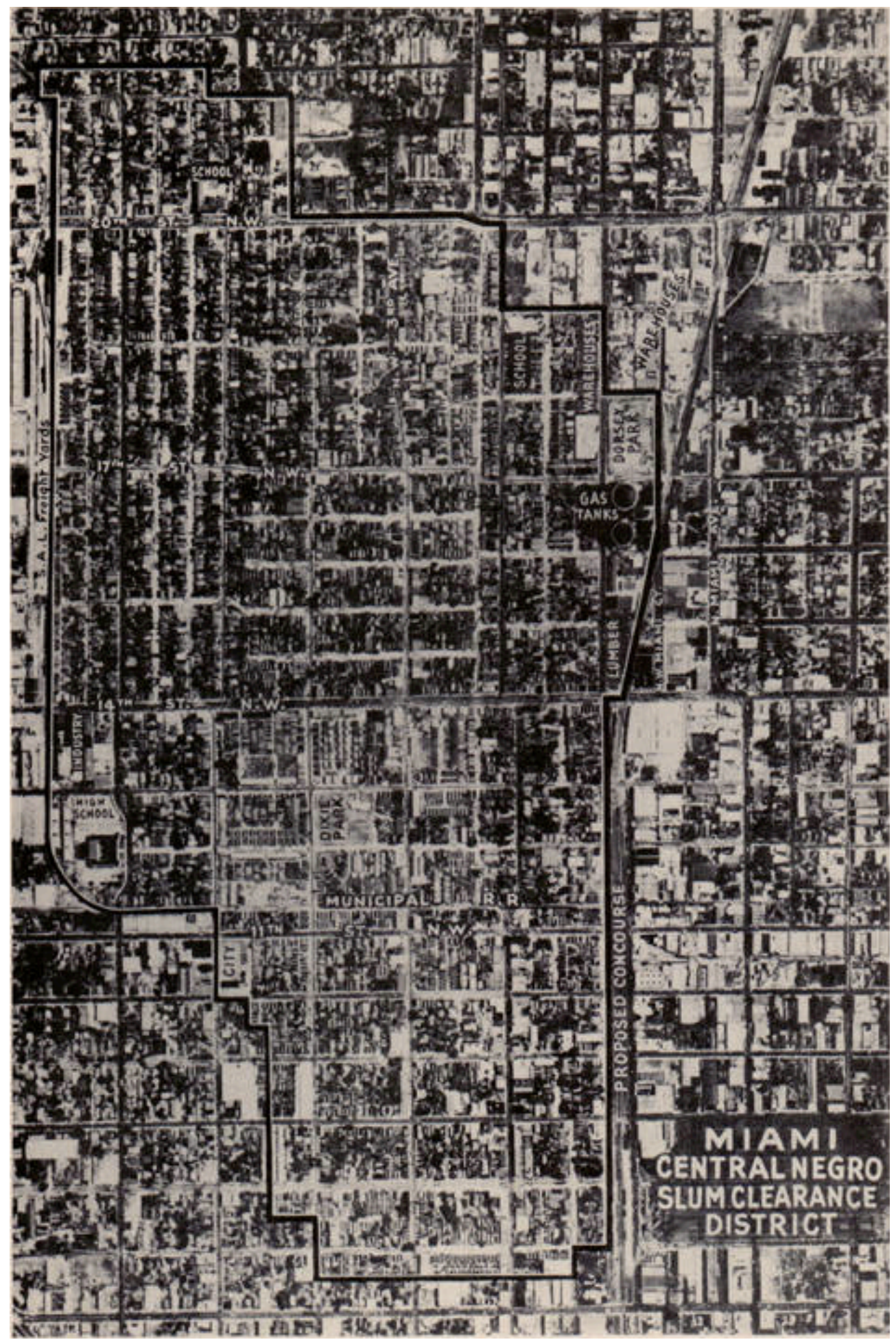

Figure 2.5: Aerial photograph map of the Central Negro District. Reprinted from the Planning Board of the City of Miami, Slum Clearance Committee, and the Dade County Health Department report "Dwelling Conditions in the Two Principal Blighted Areas." 


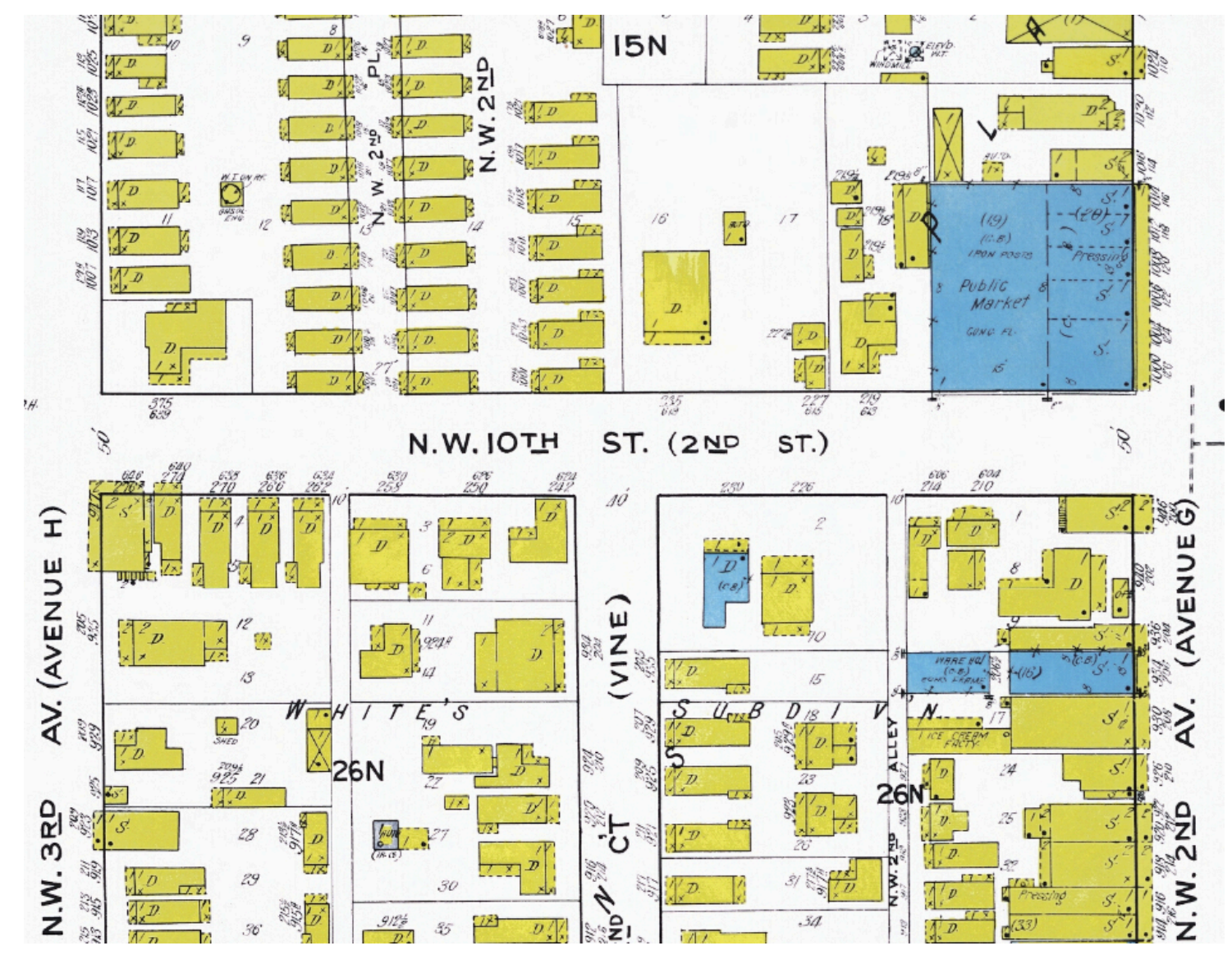

Figure 2.6: A section of Colored Town from 1921-1924 Sanborn Fire Insurance map. Accessed from University of Florida Digital Collections.

\section{Research Question \#2: What forces and events during the latter half of the twentieth century led to the formation of Overtown's "food desert"?}

This question is central to understanding the process of food desertification in Miami that began to unfold in the 1950s. My approach for tackling the question incorporated ethnographic and historical methods. Using methods similar to those described in Question 1, I first mapped the decline of Overtown's food business environment from 1970 through 2000. I then sought out personal narratives from residents and business owners who experienced Overtown's transformation during the latter half of the twentieth century. Interview questions delved into personal experiences 
of major events, including urban renewal and the 1980s riots, as well as their impact on daily life in the community, on Black-owned businesses, and on the food environment. I situated these narratives within the secondary literature on Miami and Overtown's history, which I have supplemented through a careful and critical reading of photographs, government documents, and dozens of newspaper and media stories. Government documents include expressway plans, redevelopment plans, reports on conditions in Overtown and Black business in Miami, and transcripts of Southeast Overtown/Park West Community Redevelopment Agency (SEOPW CRA) meetings. ${ }^{1}$ Miami Herald articles from 1982 onward were accessed through the FIU Library, while other newspapers were accessed through Google News or Google searches. I also located newspaper clippings and photographs from the 1950s to the 1980s in HistoryMiami's archive on Overtown.

\section{Research Question \#3: In what ways has urban agriculture been utilized to improve food access and address spatial injustices in Overtown?}

This question focuses on the role of Roots in the City, ${ }^{5}$ an urban gardening project initiated in Overtown in the early 1990s that ran for more than twenty years. In late 2011, I volunteered with Roots in the City, helping to create and tend garden rows on a vacant corner lot in Overtown. By that time, Roots in the City had become a kind of beacon for Miami's emerging urban agriculture and local food movement. As my dissertation project formed, I became interested in the historical conditions that gave rise to Roots in the City

\footnotetext{
${ }^{5}$ I received consent from Dr. Marvin Dunn to use his name and the name of his organization in this dissertation.
} 
as well as the spatial politics of urban gardening in a community devastated by state racism and on the cusp of major revitalization efforts.

I approached this question by documenting the story of Roots in the City and situating it within Miami’s economic development history. I interviewed twice the project's founder, Dr. Marvin Dunn, as well as two garden workers. I also gained perspectives of the garden from interviews with Overtown residents. During my time as an active participant of the Miami-Dade Food Policy Council (from 2010-2014), I had several informal conversations with farmers market managers, urban gardeners, food nonprofit leaders, and community activists about Roots in the City. In addition, Roots in the City received periodic coverage from the Miami Herald and the Miami New Times, whose details I carefully reviewed and cross-referenced through interviews and my own observations during several visits to the Roots in the City garden and farmers market. Finally, I examined various documents produced by the SEOPW CRA, the Knight Foundation, and the Collins Center for Public Policy, all of which provided resources to Roots in the City and shaped Overtown's redevelopment more broadly.

\section{Research Question \#4: In what ways are community redevelopment efforts reconfiguring Overtown's foodscapes? How do they impact geographies of food access and provision? What role does food play in mediating processes of gentrification in Overtown?}

This question aims to understand (however partially) the complex and shifting nature of Overtown's foodscape in the context of major revitalization as well as the extent to which food (or the commodification of food) plays a factor in shaping 
Overtown's redevelopment. To get a ground level sense of the everyday interactions in Overtown's food environments, I visited commercial, community, and charitable food spaces, including seven small groceries, two full-service and two quick-service restaurants, two soup kitchens, a shelter, one church that donates food, and a handful of community events where food was sold by private vendors. In each of these places, I used participant observation and took field notes to produce a "thick description" (Geertz 1973) of the social geographies that constitute Overtown's foodscape. I conducted interviews with residents, business owners and employees, charitable food workers, nonprofit leaders, and City of Miami and SEOPW CRA employees, focusing on the food access, changes to food environment, and the impacts of redevelopment. I also attended several CRA board meetings and reviewed their meeting minutes over the last fifteen years.

\section{On Fieldwork}

My fieldwork took place during more than forty visits to Overtown between October 2014 and October 2016. During this time, I conducted forty-four semi-structured interviews with residents, community activists, urban gardeners, neighborhood business owners and employees, government officials, nonprofit leaders, charitable food workers, a landlord, a pastor, a public school teacher, and a researcher (see Appendix A). I began my fieldwork by contacting the major community and governmental organizations involved (or once involved) in Overtown, including Urgent, Inc., Touching Miami With Love, Overtown Youth Center, Roots in the City, the Power U Center for Social Change, the Culmer Center, the Overtown Neighborhood Enhancement Team, and the SEOPW 
CRA. I conducted interviews with six leaders and staff members from these organizations to get a sense of how they understand the community and the key issues faced by residents. Food-related issues were brought up in each of these interviews, either in terms of access to healthy food or the need to bring in a supermarket and restaurants to improve Overtown's retail landscape. At the end of each interview, I asked interviewees if they would share contact information of residents, business owners, or other people working in Overtown who could speak to matters of food access or food-related development in the area. In this way, I met many of my research respondents through purposive snowball sampling.

I also attended public meetings held by the SEOPW CRA and the Overtown Community Oversight Board to better understand how the process of community redevelopment is mediated at the governmental level. During and after these meetings, I was able to meet residents, learn about their concerns, and describe the focus of my research. One person who had a particularly active voice in, and for, the community would become invaluable in helping me think through my project, read through the political moves of local officials and community leaders, and connect with people who live and work in Overtown.

Additionally, I met with owners, employees, and patrons of small groceries and charitable food organizations to get an on-the-grounded sense of Overtown's neighborhood food environment. Here I was able to learn about residents' shopping patterns and food preferences, the various challenges of running a small grocery, and a range of perspectives on how Overtown's food landscape is changing (or will change) in the context of looming redevelopment. 
Finally, after establishing a rapport with several people living and/or working in Overtown, I made regular visits and, in doing so, met people walking around and "hanging out" in the neighborhood. Oftentimes, because of the ways I am physically marked as an outsider to the community (a white, bearded man in his early thirties usually wearing a plain polo or T-shirt, shorts, and sneakers with a small writing pad in hand), people questioned my purpose. In some cases, residents were concerned or at least skeptical that I might be working undercover for the police, while in others people asked if I was a reporter or journalist. In all of these cases, I made it very clear that I was a graduate student conducting research, presenting people with my student ID and, though not always eloquently, trying to describe my research topic in a succinct way.

Perhaps unsurprisingly, I found out that people in Overtown did not always want to talk about food with an unknown researcher during their first - or even fifth - meeting. Their daily concerns and struggles of coping with poverty and oppression, even if foodrelated, can be quite distant from the research questions I was bringing from academia to the community. While I initially tried to guide conversations to cover food matters, I later decided to put many of my predetermined questions aside, decenter my authority and purpose, and listen to a much wider range of concerns and sentiments expressed by the people of Overtown. In taking this approach, I found that people were far more likely to invite me to walk or ride with them or sit in their shops or at a bus stop and talk. They also put me in contact with others whose perspectives they trusted. In some cases, it took several meetings before someone was comfortable talking with me. Still for others, whose wariness of me or disinterest in my research remained, I tried to be respectful and leave them alone, removing myself from spaces where I felt my presence was imposing. I 
never achieved that magic moment where I became fully accepted by "the community." Rather my access to people was constantly negotiated, as Crang and Cook describe in Doing Ethnographies (2007).

Ultimately, I believe this mode of engagement allowed the community I was immersed in to play a larger role in shaping the research process. Though my research was not a participatory or community-based project driven by the study's participants, it was profoundly affected by the ways in which people responded to my presence and stated interests. It also yielded a much richer understanding of life in Overtown and provided a deeper context for understanding how food environment issues are interrelated with a wider web of issues. 


\section{THE VEINS THAT FED THE PEOPLE: FOOD, ENTREPRENEURSHIP, AND PLACE-MAKING IN JIM CROW MIAMI}

This chapter draws from the geohumanities and other interdisciplinary approaches to reconstruct a historical geography of Black survival and place-making in Jim Crow Miami. Specifically, the chapter integrates historical, geospatial, and ethnographic methods to unearth the early and mid-twentieth century food environments of the historic Overtown neighborhood, or what was first officially Colored Town, and later, the Central Negro District. While Overtown today is often labeled a food desert, hidden in time existed a rich foodscape composed of grocery stores, meat and fish markets, produce stands, barbecue joints, restaurants and luncheonettes, bakeries, confectioneries and ice cream parlors as well as a host of household spaces where neighborly practices of commensality brought Miami's diasporic Black people in intimate contact. I argue that food played a central role in Black people's practices of self-reliance, amounting to the development of self-sustaining neighborhood systems of commerce and care. Food became a medium that linked bodily sustenance, family livelihoods, community building, and racial solidarity among African Americans and Afro-Caribbeans forced to make a home under the same racial roof. In very real and substantial ways, Blacks in Colored Town were able to reduce their dependence on white-dominated industries for nourishment and employment, effectively loosening the social and economic grip that white supremacy had over their lives.

The chapter combines geospatial mapping with historical analysis to present an interpretive spatial history of Colored Town's foodscapes. I draw heavily from oral histories conducted by the Black Archives History and Research Foundation of South 
Florida, highlighting many of the rich accounts about the role food and food businesses played in the everyday life of Black residents and entrepreneurs. Ultimately, by using the lens of food, this chapter reveals a lost geography of Black survival in a segregated city growing at the nexus of the US South and the Caribbean during the early and midtwentieth century.

\section{The Caribbean Making of the Magic City}

Near the end of the nineteenth century, the building of a new city, Miami, and the Florida East Coast railroad that connected it to northern destinations began to draw scores of Bahamian and other West Indies migrants in search of work. At this time, most of these migrants would labor, save money, and return to the islands and their families. Blacks migrating from parts of the US South, on the other hand, were much more likely to stay. According to Miami's 1900 census, conducted just four years after the city's incorporation, out of 599 Black residents only 25 Black Bahamians claimed residency. But this would soon change. In 1909, a Miami Metropolis newspaper headline read, “More Than Thousand Bahama Islanders Reach Miami during Year" (Peters 1985, 95). Bahamians continued to immigrate in large numbers to Florida throughout the 1910s to work in citrus and vegetable production, on the extension of Henry Flagler's FEC railroad into the Florida Keys, and in the quickly expanding Magic City, where it was rumored that "money could be 'shaken from trees." (Reid 1939, 184). Bahamian laborers were especially sought after because of their homeland experience building structures out of oolitic limestone, the immediate substrate on which much of South Florida's earth rested. Indeed, they would soon comprise the bulk of the labor force that 
upturned Miami's underground sea fossils and sculpted the city's growing, and glistening, architectures.

The coupling of Florida's agricultural boom at the onset of World War I and a declining sponge and tropical fruit industry in the Bahamas sent even more islanders abroad. Economically, most Bahamians were better able to earn a living working the highly productive citrus groves and vegetable farms or doing construction than negotiating life on British colonial plantations (Mohl 1987). Immigration from the Bahamas and the greater Caribbean swelled so much that by 1920, Black immigrants in Miami outnumbered native-born Blacks (Miami Herald 1920). While this waxed and waned some during the 1930s Depression era, labor shortages in agriculture during World War II spurred federal recruitment initiatives for Bahamian labor in south Florida. Immigration policy at this time generally refused foreign arrivals, but the US government created a loophole, deeming Caribbean recruits as temporary "guest workers" (Hahamovitch 1997; 2011). Bill Sawyer, who managed the largest Black hotel in the South, the Mary Elizabeth Hotel, was hired by the government to find housing for new arrivals. "I can remember when... these people all began to migrate to Miami, they just came over in loads. I used to find room and provide places to stay for the people that was coming there because they were Colored, you know, and used to see that they got their food and what not ... The government had me do that."

Colored Town grew to become an inseparable hybrid of American and Caribbean Black diasporic cultures. Historian N. D. B. Connolly writes,

\footnotetext{
${ }^{6}$ Bill Sawyer, interviewed by Stephanie Wanza, 25 August 1997, Tell The Story Collection, Black Archives.
} 
Unlike the majority of segregated Afro-America, this community was one where Cubans, Jamaicans, Bahamians, and American Blacks shared fruit trees and family trees, clotheslines and bloodlines...Overtown was a viable and valuable safe-house for a truly Atlantic culture, a 'more-thanAmerican' space sustained by the everyday community-building activities of ethnically diverse people of African descent. (2006, 7-8)

In similar fashion, historian Raymond Mohl writes,

From Miami's earliest days in the late nineteenth century, the Bahamian presence made the city's Black population distinctively different from that in most southern cities. The Bahamians had an impact on food ways, cultural patterns, work habits, educational aspirations, musical and artistic activities, and other social characteristics. $(1987,295)$

Yet while food is emphasized in both of these passages, our understanding of the foodways and food landscapes of historical Overtown are heretofore limited to these kind of vague descriptions of Caribbean influence. Part of what I hope to convey in this chapter is that the making of Colored Town entailed a continued syncretization of food practices between Africans, African Americans, and Afro-Caribbeans that had been taking place for centuries. In other words, when Bahamians arrived in south Florida, they not only brought "their peculiarly West Indian vegetables: yams, casava, eddys, pounders, and benni," as George Merrick $(1941,2)$, an early twentieth century real estate pioneer whose developments employed legions of Bahamians, remembered. They also came with a set of cultivation knowledges, food procurement strategies, and cooking practices that were first developed on the African continent and reconstituted on American and British plantations. These foodways met with those of Black people from the rural US South who brought to Miami a set of culinary and dietary repertoires also stemming from West African traditions, yet adapted to provide palatable sustenance during American slavery. Today, Overtown's neighborhood foodways still reflect this 
creolization, as conch salad, boiled fish and grits, pigeon peas and rice and souse are prepared and eaten in a number of alimentary settings.

Of course, this process did not happen in a vacuum. Overtown's food culture was also shaped by the material realities of segregation.

\section{The Double Standard of the Color Line}

From its earliest days, Black settlement into Miami spurred an immediate social engineering and urban planning effort by white city officials and homeowners. As soon as the first tracks of the FEC railroad were laid down, they marked both the physical and symbolic racial divide between the town's residents and "served as the colour line between two work camps - one for 'whites' and the other for those deemed 'coloured"' (Connolly 2009, 246). Black migrants from both the US South and the Caribbean were discouraged from encroaching into white areas through a number of ways. Visible spectacles of anti-Black violence committed by police officers and white residents would go unpunished. During the 1920s, as Miami's tourism industry picked up speed, city officials issued a series of mandates and interventions to prevent racial mixing. Black performers were barred from playing in white venues, zoning restrictions prevented Blacks from residing in white communities, and curfews were established to keep Blacks and whites from engaging in late-night sexual interludes. Following a heated conflict pertaining to the areas of town Black and white chauffeurs could service, a 1921 city charter drafted by white elite city commissioners codified racial residential districts and “explicitly forbade 'negroes' and 'whites' from establishing businesses in districts set 
aside for the racial other" (Ibid., 249; see also Castillo 2009; Dunn 1997; Shell-Weiss 2009).

But while these laws and customs prohibited Blacks from living and doing business outside their communities, they did little to steer white investors and businesspersons from capturing Black capital. Not only was it true that "enforcement tended to be one sided," but such laws helped construct an enormously lucrative market in Black slum housing (Connolly 2009, 249). Noticing the rapid boom in Miami's growing population, investors saw great promise in an emerging "Negro rental market" where Blacks had no real housing options outside of fixed racially designated zones (Connolly 2014). Lots could be purchased with little restrictions on the number of dwellings built on them. As the population of Miami's densest neighborhood continued to swell throughout the first half of the twentieth century, landlords, most of whom were white and absentee, installed wood-frame shotgun-style houses edge to edge on each lot to maximize their potential profits. While some wealthier Blacks did own their homes, and sometimes other properties, they represented a small segment of the overall community. In fact, by the 1940s more than ninety percent of Colored Town residents were tenants (US Census Bureau 1942, 21-22).

\section{Food at Home}

The creation of a Black housing market in segregated Colored Town would have profound effects on the food landscapes that emerged in and around people's homes. For one, it largely shaped the material geography of the housing and commercial structures. In the 1920s, during the height of Miami's first real estate boom, over two thousand 
shotgun homes were erected in Miami's central Black district. Shotgun houses were not only cheap to construct, but also stemmed from African-influenced architecture and had been commonly built throughout the slave South and the Caribbean (Vlach 1986). The typical dwelling featured no hallways and consisted of one room behind another, such that a shotgun could be fired through the front door and exit out the back.

In the most squeezed stretches of housing "each house [was] facing the other. I could leave out of my kitchen and go into your kitchen. That's how close we was."” Though the slums left little room for household privacy, some remembered the physical proximity to one's neighbors fondly. One resident felt that this housing arrangement brought a sense of "unity, in that you lived two steps away from the next apartment door. So it was very hard for you not get along and not to have a good relationship with the person that you lived so close to... It was a close knitted environment." ${ }^{18}$ George Lipsitz writes of similar shotgun housing conditions in Houston in which "density also promoted mutual recognition and conversation... The uniform design of the houses emphasized the unity of their inhabitants as people who not only lived in their own individual dwellings, but also shared a neighborhood and a community" $(2011,154)$.

One section of Colored Town, famously known as "Good Bread Alley" for both its lucrative opportunities for prostitution and gambling as well as the appetizing smells emanating from kitchens, exemplified the tightest of compartmentalized housing in those

\footnotetext{
${ }^{7}$ Quoted from the film, Purvis of Overtown, directed by Shaun Conrad and David Raccuglia, Rural Studios, 2004.

${ }^{8}$ Reverend Clayton Harrell, interviewed by Stephanie Wanza, 14 August 1997, Tell the Story Collection, Black Archives.
} 


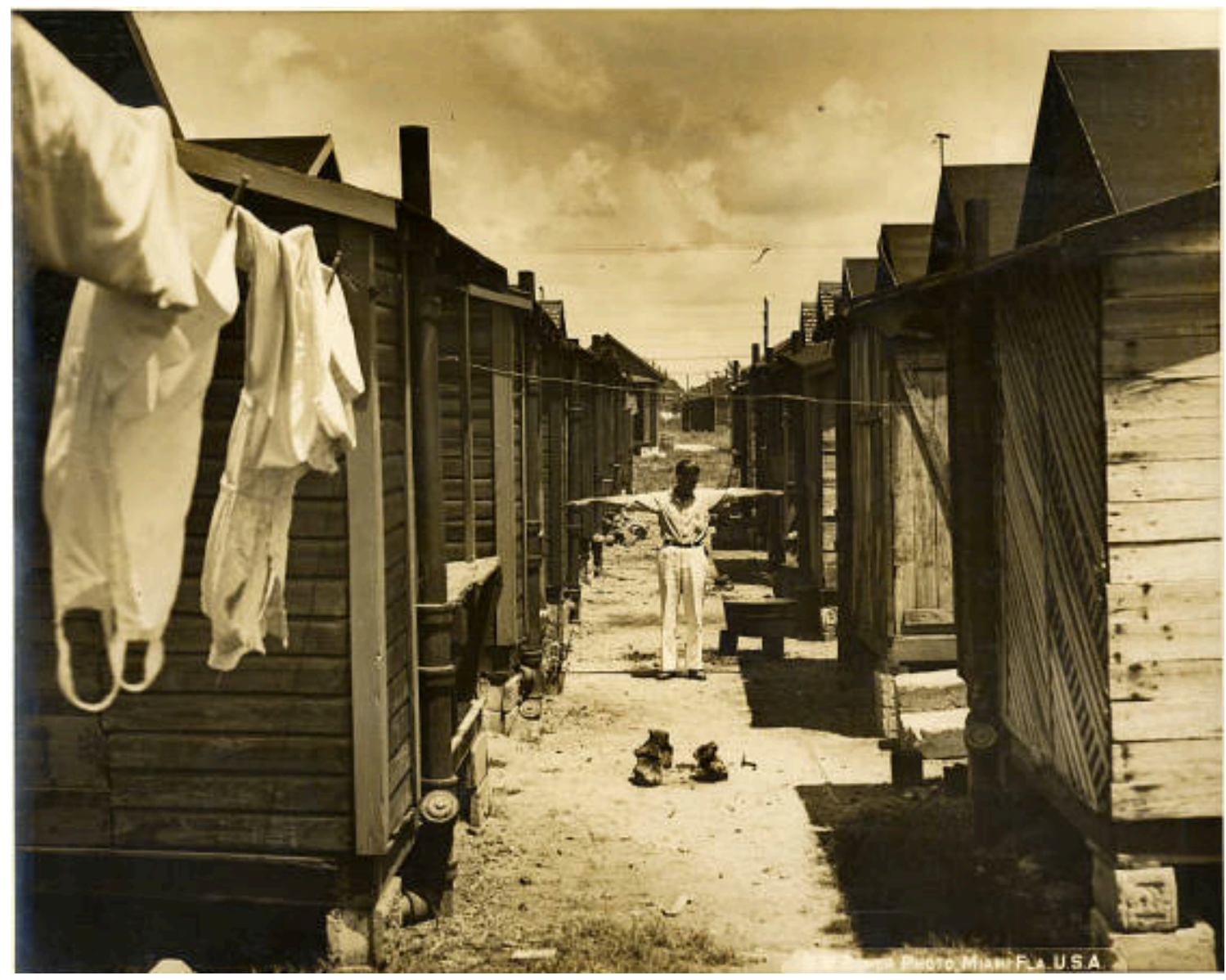

Figure 3.1: Typical alley in a strip of wooden slum housing. Reprinted from Romer Collection, 761C, Miami-Dade Main Library.

days (see Figure 3.1). But while the crowding of homes certainly sandwiched neighbors together, recollections from former residents describe food aromas as a central thread of intercultural connection. Longtime resident William McDonald said: "You open your door, you see the person right in front of you. You could cook and smell them cookin'. You could tell what they cookin', whether it was fried chicken, pork chops, cornbread, pancakes, whatever. But you always smell that Johnnycake, that good bread."9 These smells that wafted from kerosene stoves in home kitchens into the narrow alleys might

\footnotetext{
${ }^{9}$ Quoted from Purvis of Overtown.
} 
even signify who was doing the cooking. For example, Irby McKnight described how "southern Blacks and Caribbean people who made up the residents there cooked different kinds of breads. The [US-born] Blacks did the syrup corn bread that has a very delicious smell, the cracklin' corn bread that smells even further, and the Bahamians made the Johnnycake."10 As mentioned, food practices in the neighborhood bore distinctly Bahamian influences. One Bahamian resident recalled, "I remember everybody in the Alley had a crab net, a crab cage by their house... It was like millions of blue crabs, land crabs, and they use to go out, catch, and then they would bring them back, and then when they wanted a pot of crab and rice or crab pilau [pronounced perlow], they just went in and got the crabs, cooked them up, you know, and ate them." 11

The origins of foodways of Colored Town residents can be traced to Africa, the US South, the Caribbean, and the back and forth migrations of food and food knowledges between these regions. While it is more commonly known that Africans brought rice and their native crops of okra, yams, and melons to the so-called New World, the influence of crops from the Americas had also made its way eastward across the Atlantic. For instance, after its introduction to West Africa during the fifteenth century, maize was widely cultivated and integrated into African agriculture by the early 1800s (Corry 1968; Lewicki and Johnson 1974; Winterbottom 1969). Cultivars indigenous to the American tropics, such as pineapples, guavas, cassavas, and soursops had also been incorporated into West African diets (Cruickshank 1966). The dietary preferences combining shellfish with rice as described above stems from two converging foodways: the "planting" of rice

\footnotetext{
${ }^{10}$ Quoted from Purvis of Overtown.

${ }^{11}$ Joseph E. Dames II, interviewed by Electra R. Ford, 21 August 1997, 22, Tell the Story Collection, Black Archives.
} 
cultivation practices from Sierra Leone and Senegambia into the Carolina Low County which were subsequently planted in the Caribbean after British Loyalists moved their slaves there - and the consumption of marine resources that continued from coastal West African traditions into American South and Caribbean contexts (Carney 2001; Creel 1988; Farnsworth and Wilkie 2006; Joyner 1984).

These foodways further developed in response to the resources available in and unique conditions of segregated Miami. In the context of multiple ethnic communities joined in a state-fashioned bond of racial subordination, food was key in the building of intimate relationships across cultural lines.

The people, you know, we shared dishes. We had a diversity of people... There were some people ... who had migrated from the Bahamas living in our neighborhood and you could smell the Bahamian food, and then we had some from Georgia and you could smell that, too. And naturally they would share their collard greens and cornbread with us and we would share our Bahamian dishes with them but ... everybody learned to cook the same thing and, of course, we sort of like came into a melting pot there. ${ }^{12}$

Here cooking was more than a signifier of cultural traditions; it was also a medium of cultural integration, a mixing of different ethnic and affective influences, which were then slowly simmered and melted together. This process helped meld what would over time become a common cuisine among residents in Colored Town, a cuisine developed out of the familiarities with African, American, and Caribbean food traditions.

At the same time that food brought people together, however, it also symbolized class distinctions, usually between the propertied class whose homes were sometimes shrouded in fruit trees and the working-class and destitute whose homes were thinly

\footnotetext{
${ }^{12}$ Leome Culmer, interviewed by Stephanie Wanza, 13 August 1997, Tell the Story Collection, Black Archives.
} 
separated by dusty, unpaved alleyways. Vegetation in the latter was minimal. One resident described her street as, "Just sandy ... The only foliage you had was what you planted, you know, bushes and stuff like that. Every once and a while you'd see a tree."13

Gloria Littlefield remembered her home quite differently. "We had all kinds of fruit trees in the yard. We had five coconut trees in the front yard and a guava tree and mango trees and avocado trees, and we had more trees than we did house." ${ }^{14}$ While not quite a member of the Black upper elite, Gloria's mother owned, in addition to her home, a six unit apartment that she collected rents from. Roberta Thompson, born into a prominent Black family, grew up in a home with "a large yard and in the yard we played baseball and jump rope. We also had a garden in the yard and we helped to take care of the garden. We had both vegetables and flowers over on Tenth Street. We also had coconut trees and orange trees, and you name it we had it." ${ }^{15}$ Rachael Williams, the daughter of an agent at an African American insurance company, remembers "many, many trees in our yard. Mangoes... sapodilla trees, sugar apple trees, lime trees, grapefruit trees, pear trees - they were all in our yard. We had double lots and the lot ran from $3^{\text {rd }}$ Avenue clear through to $3^{\text {rd }}$ Court." 16

In a climate where tropical plants flourish almost year round and in a neighborhood where few people owned their homes, perennial fruit trees and gardens

\footnotetext{
${ }^{13}$ Marian Shannon, interviewed by Yvonne Daly, 15 August 1997, 14, Tell the Story Collection, Black Archives.

${ }^{14}$ Gloria Littlefield, interviewed by Devon Williams, 12 August 1997, Tell the Story Collection, Black Archives.

${ }^{15}$ Roberta Thompson, interviewed by Electra B. Ford, 29 August 1997, Tell the Story Collection, Black Archives.

${ }^{16}$ Rachel Williams, interviewed by Electra B. Ford, 19 August 1997, Tell the Story Collection, Black Archives.
} 


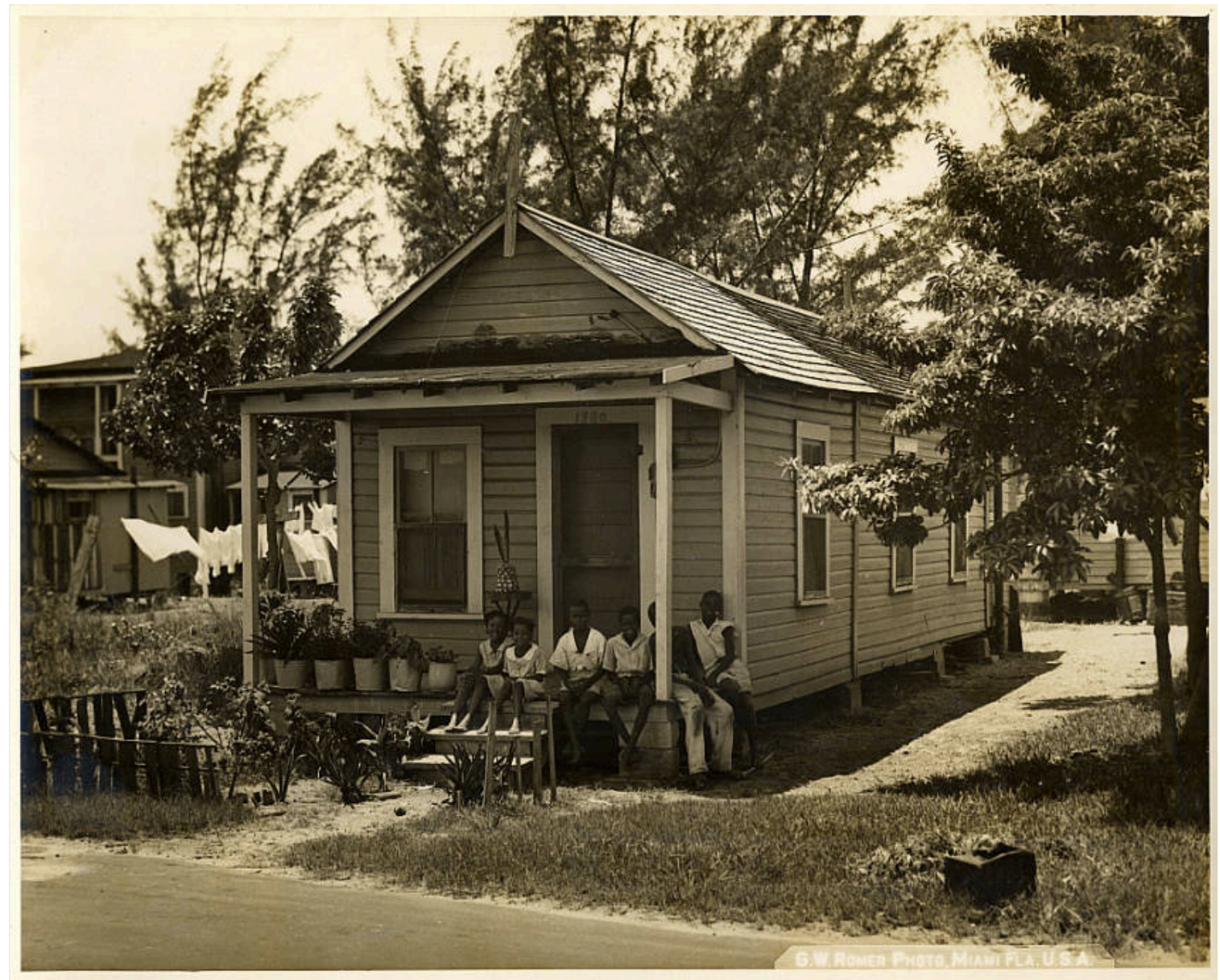

Figure 3.2: Home in Colored Town next to a fruit tree. Picture titled "Six children on an Overtown Porch.” Reprinted from Florida Photograph Collection, University of Miami Libraries, Special Collections.

came to symbolize the material fruits of property ownership. Well-to-do homeowners not only had the space to endeavor in horticulture, but their residence's permanency allowed their fruit trees to reach maturity (see Figure 3.2). As one's trees grew, their home represented how long they were established and institutionalized within the community. In this way, the dichotomy imposed between property owners and renters heavily shaped the residential foodscapes of different parts of Colored Town. Smells, tastes, and sights of foods spoke to culture, wealth, and status. The economy of these sensations, however, 
differed block to block. In the close quarters of the slums, food enabled residents to know their neighbors olfactorily. In the homes of wealthy, the sight of food informed.

But while residential food landscapes revealed classed differences, they did not inherently separate Blacks along economic lines. Most accounts of residents who lived in Colored Town describe a community networked across their differences, a "community where Blacks from across Africa's diaspora built viable institutions and espoused on American soil the same multi-ethnic, cross-classed nationalism that peoples of color were building in other Caribbean locales" (Connolly 2006, 7-8). As one former resident remembered, the sharing of fruit from one's trees was a key feature of everyday community-building:

[I]f anybody needed you to run an errand for them, you didn't have to put your hand out asking for anything. Maybe they didn't have anything to offer you but then some day you might be walking by that same person's house and they call you with a few mangoes or a few oranges - because fruits were plentiful at the time - and you take them home and your parents, you know, would know about it, ... they'd express their appreciation. That's the way it was." 17

Fruits and other foods circulated in the myriad exchanges of reciprocity, opening lines of connection between neighbors.

Black Entrepreneurship in Food

It is hardly possible to place too great stress on the deep significance of business ventures among American Negroes. Physical emancipation came in 1863, but economic emancipation is still far off.

W. E. B. Du Bois, The Negro in Business, 1899

\footnotetext{
${ }^{17}$ Ralph McCartney, interviewed by Devon Williams, 14 August 1997, Tell the Story Collection, Black Archives.
} 
Food played a central role in Black entrepreneurship. Drawing from the spirit of Black enterprise inspired by Booker T. Washington, W. E. B. Du Bois, and Marcus Garvey - however different their ideologies and goals - Blacks were able to build a prolific network of businesses that served the dense community in which it was embedded. For many Black entrepreneurs, racial segregation nearly guaranteed a steady clientele with which to conduct business. Blacks were not permitted to go outside their neighborhoods after sundown, which made shopping risky for those attempting to grab their goods later in the day. Said one former resident:

We knew that we could not go... downtown to do very much shopping, especially at certain times. If you were down there at five o'clock you better run and try to get home before dark ... They [the police] would beat some of them up or say maybe 'just get back across the track' or something like that. But you knew you had to hurry to get home. For that and other reasons, there were so many families who got together and had grocery stores. ${ }^{18}$

Indeed, of all the businesses that Blacks created during this time, food businesses

were the most common, particularly small groceries and restaurants. For poor migrants who had grown up in agricultural contexts, food businesses were viable starting endeavors in enterprise, as their operation did not require much initial capital or specialized education (Poe 1999). In Du Bois's 1899 study of Black business in the US, The Negro in Business, a Black grocer from Atlanta describes the circumstances under which Blacks entered business in the post-Reconstruction era:

... the Negro Grocer of Atlanta, some of whom, years ago, embarked in business, with no capital, save a few dollars, his honest heart and his necessity; no established credit; ignorant of most of the ordinary rules of business, many of them, at the start would not have known an invoice

\footnotetext{
${ }^{18}$ Roberta Thompson, interviewed by Electra B. Ford, 29 August 1997, Tell the Story Collection, Black Archives.
} 
from a bill of lading; with nothing to guide him but his native shrewdness and nothing to save him from disaster, save what he might accumulate by the strictest economy.

According to Du Bois's study, grocers, caterers, restaurant-keepers, dairymen, confectioners, bakers, and dealers in meat, fish, fruit, and feed comprised over a third of all reported businesses. By 1928, grocery stores and restaurants alone accounted for 30 percent of all Black-owned businesses in the US (Johnson 1930). Based on my research and analysis of city business directories, in Miami's Central Negro District, as early as the mid-1930s and up until the early 1960s, Blacks alone would run more than one hundred officially recognized food-related businesses in any given year. For many Black entrepreneurs, these endeavors in self-employment marked the first time they were their own bosses and worked on their own terms, an opportunity that was a profound shift from sharecropping or tenant farming for, usually, white planters. Operating one's own business also afforded Blacks more autonomy compared to the jobs they typically found in white hotels, restaurants, stores, and homes.

Such was the case for Radie Jackson. At the age of eight, Radie, the son of a West Virginia livestock farmer, dreamed of owning his own business. During his days helping out on the farm, he watched his father conduct business with representatives from major meat firms like Armour and Swift. As he grew older, he travelled from his home state to work in hotels and cafeterias on Miami Beach during the winter's high tourism season. In 1934, he moved to Miami and continued to work for wages in food service establishments, the last of which was Hoffman's Cafeteria located two blocks away from the gently crashing waves of the Atlantic. Seven years later, Radie opened Jackson's 
Restaurant in the heart of the Central Negro District's "Little Broadway" section. Radie recalls:

I was in the restaurant business, and that was during the war, and I was doing very well. Everything was rationed, but somehow or another I still was able to get some meats and stuff to sell, go to the country and buy chickens on foot and dress them and sell them. Sometimes I could get a hog that was already dressed and sell it, and then that way I was able to keep food in my restaurant because there was very much rationing during them years, and I was in the restaurant business up until $1950 .^{19}$

Yet Radie's success came at the expense of long and exhausting working hours.

At the crack of dawn, he was selecting chickens on a farm eight miles outside of Colored Town or shopping for string beans, green vegetables, oranges, and other produce at a nearby farmers market. He also might drop by the butcher shop for chicken and hamburger meat. "My hours was long... I would go to the market early in the morning around 6 o'clock and I would close at night, say around 12:30 or say sometimes 2." Located right in the heart of Overtown's hotel and nightclub district, "Little Broadway", Jackson's restaurant served much of the entertainment seekers as well as the performing national acts, including jazz greats like Louie Armstrong, Erskine Hawkins, and Chick Webb. After nine years of little sleep and endless labor, Radie decided to cash in and turn over the restaurant. He first joined the Painters' Union before later landing construction work and finally developing homes in Overtown and nearby Opa Locka. ${ }^{20}$

Food ventures like these were often the first step in a career of other business ownership pursuits. Working for the Royal Palm Ice Company and, later, a local fish market, John Barkley also dreamed of owning his own business. In 1924, he and his wife,

\footnotetext{
${ }^{19}$ Jackson Restaurant. AT\&T Miami-Dade County African-American History Calendar, 1998/1999, Black Archives.

${ }^{20}$ Radie Jackson, Tell the Story, Overtown Oral History Collection.
} 
Mattie Smith, opened a Piggly Wiggly grocery store beneath their home on the corner of NW $15^{\text {th }}$ Street and $5^{\text {th }}$ Court. In 1940 , the Barkleys opened a sundry store, which earned them enough money to purchase the building that housed it from the Gulf Oil Company. "At the time, the building's purchase was one of the biggest real estate transactions ever in the Washington Heights area of Overtown."21

After completing a stint as a postal worker in Cuba, Sonny Wright found himself stuck in Miami, waiting for his final paycheck to arrive. With nowhere to go, "Mrs. Rose," who owned the Georgia Café, "took me in, and I used to do whatever I had to do and she just provided me in a lot of different ways - afforded me a place to stay and food, put money in my pocket so I felt as part of the family ... after I was there for a while.” A few years later, Sonny opened his own restaurant, which became a favorite place for Muhammad Ali to visit. And despite the economic failings of this venture, it would prove an important experience for his later success:

Well actually success is, of course, a relative thing, and I don't think, if you think in terms of money, I don't think I can consider myself a successful restaurant operator, but in terms of what it meant to me even to this day, in terms in my understanding of business and to make things happen, I think I was very successful because at the time I was only 20,21 years old and I was running my own business, and I learned a lot about how to survive I guess. So that extent I suppose it if there was any success that was success to learn to the business to learn how to be in business. ${ }^{22}$

Sonny Wright would later sell two restaurants and have a very successful career in real estate and eventually became owner of Dade County's first Black-owned bank.

\footnotetext{
${ }^{21}$ Barkley, John M. and Mattie. AT\&T Miami-Dade County African-American History Calendar, 1996. Black Archives.

${ }^{22}$ Sonny Wright, Tell the Story Collection, Black Archives.
} 
Many Blacks also ran food businesses on the streets or next to - or even out of their own place of residence. While my research of Miami's business directories revealed no record of entrepreneurs selling food out of carts, photo documentation (shown below) by Max Waldman shows some evidence of this practice (see Figure 3.4). Said one resident, "Most of the Bahamians, [...] a lot of them owned their business because that was their trade from where they came from. They had [...] mom and pop businesses right connected to their houses and they sold and they cooked pies and [...] that kind of work." Directories, when cross-referenced with manuscript census records, account for several businesses run out of or near people's homes. As Connolly (2014) describes, because the Central Negro District's dense housing was owned primarily by absentee landlords whose primary if not only concerns were receiving rents, renters were virtually free to operate their dwellings as they saw fit. Some turned their homes into rooming houses, renting rooms out to subtenants. Some made their homes available for vices like gambling, prostitution, and moonshine distribution, while others opened groceries, restaurants, and other business ventures. One white slumlord explained, "You can have a colored man operate [your real estate] for you and he can run it as anything he wants. The colored man can make a bundle on the side and you'll get yours" (cited in Connolly 2014, 81).

For example, a 1940 census reveals that Benjamin Branham's primary occupation was running a grocery store out of his home, which in 1939 earned him $\$ 1,000$ annually, or about $\$ 17,000$ in today's dollars. Benjamin and Caroline Bethel, a couple from the Bahamas, owned their home, and rented it out to 10 other Black lodgers. In addition, their home served as a fish market. Fred and Gertrude Noble, a Jamaican couple, rented a 


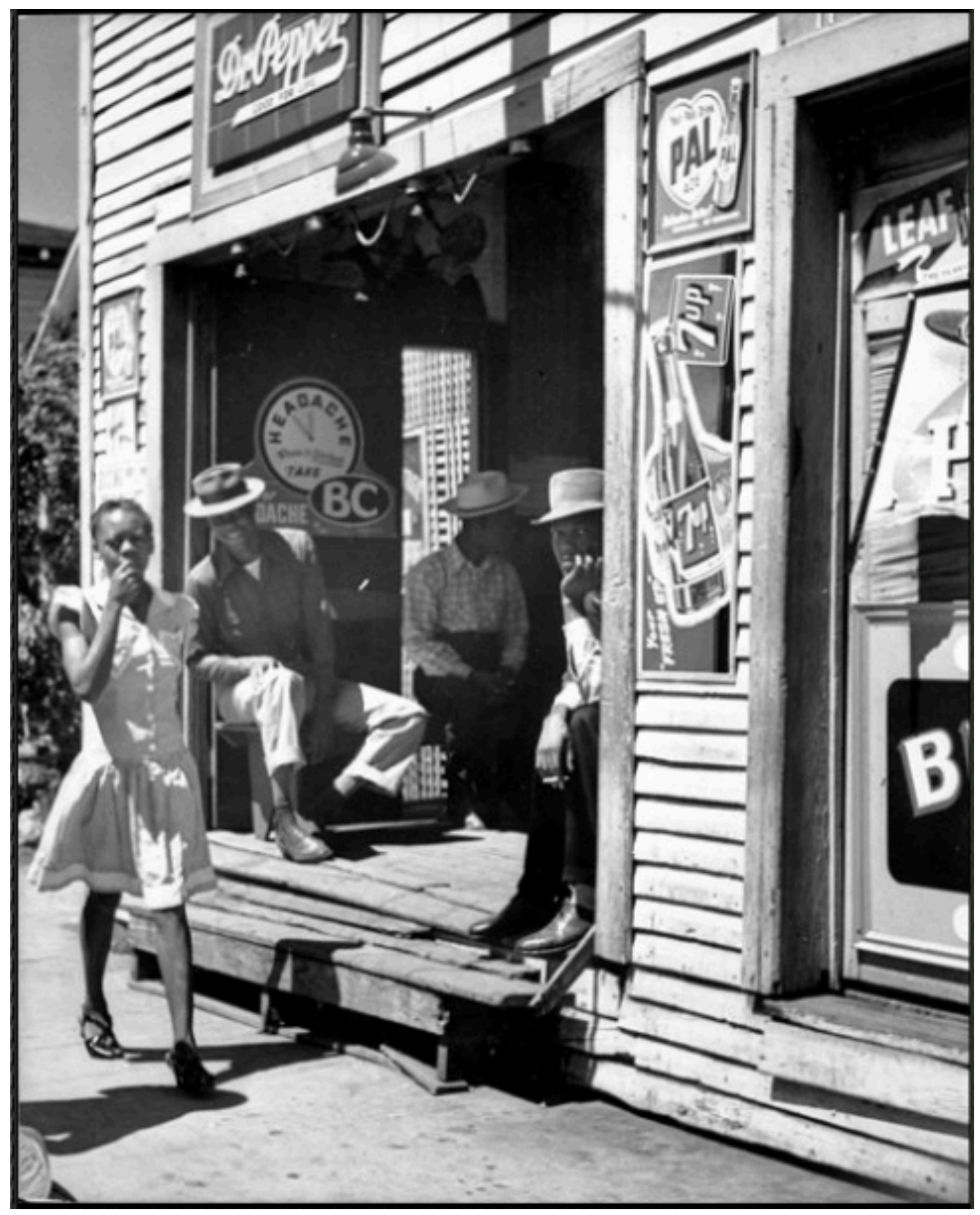

Figure 3.3: Woman walking by a business occupied by men in the Central Negro District. Titled “Color Town \#4." Reprinted from Max Waldman's “Color Town: A Southern Black Community," Prints and Photographs Division, Library of Congress. 


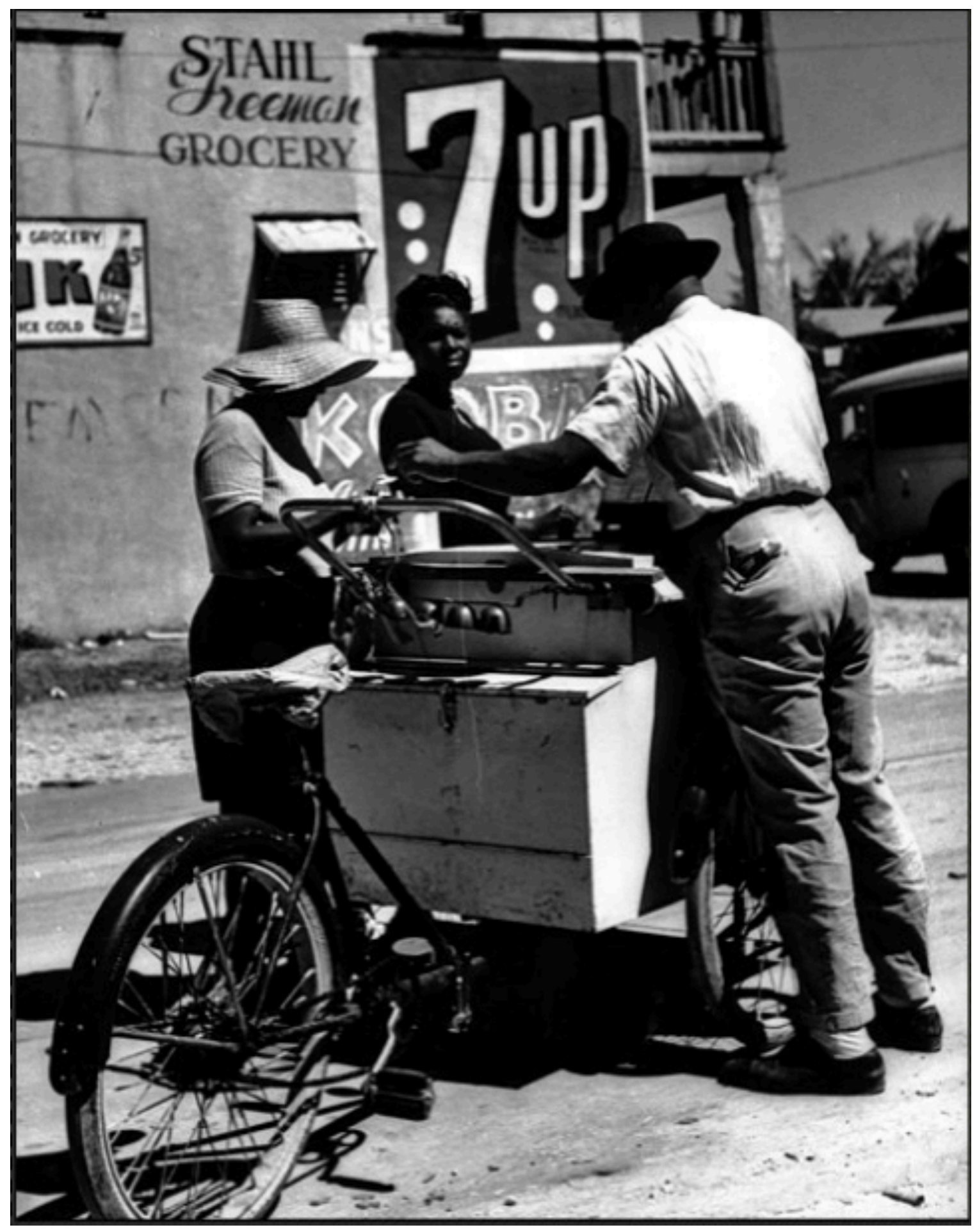

Figure 3.4: Man selling goods from street cart with Jewish-owned grocery in background. Titled "Color Town \#9." Reprinted from Max Waldman's "Color Town: A Southern Black Community," Prints and Photographs Division, Library of Congress. 
home for $\$ 68$ a month and then rented their home to seven other lodgers. Next door they ran a small grocery to supplement their income. Residents like Ellis and Annie Howell, originally from Georgia, ran a luncheonette out of the same home that they rented to five other people. This was not uncommon in Colored Town. One resident said: "There were small grocery stores, many of them, and even some families had stores right next to the house like they have in the Bahamas. That's what they have in the Bahamas, that family had a little store, they made a little help to get their little living off that store." ${ }^{23}$ As another former resident described, there

was a barbecue place, and every weekend that's where we went to get barbecue. We could get barbecue, souse and conch fritters, and it made it nice. You looked forward to the weekend, and it wasn't a fancy place. The gentleman sold it from his house, and he invited you to sit on his porch and eat, and you would sit there and you would meet others as they would go and come, and you would meet new people all the time..$^{24}$

These examples illustrate the interrelated worlds of production and social reproduction among Black-owned businesses in the Central Negro District. These businesses, or what some called "hole in the walls", were popular neighborhood hangouts at the same time that they were key to keeping a roof over one's head. They sustained Black livelihoods at the same time that these livelihoods circulated resources within their home community.

Given such a wide array of choices, many residents recall doing their food shopping from several different venues: "[Y]ou know you would get the chicken from

\footnotetext{
${ }^{23}$ Roberta Thompson, interviewed by Electra B. Ford, 29 August 1997, Tell the Story Collection, Black Archives.

${ }^{24}$ Andel Mickens, interviewed by Yvonne Daly, 12 August 1997, Tell the Story Collection, Black Archives.
} 
down there and eggs from Mr. Steward's poultry shop and, you know, the big grocery

store was like back there on First Avenue I think it was and, I think it was called

Tanners. ${ }^{25}$ More descriptively, Edward McKinney recounted:

[M]y grandmother was of a very conscientious shopper. If something was five cents or two cents cheaper at that store, you went over there and got that, then you got the other stuff at this one so you vacillated between the two stores and $[\ldots]$ then she might wanted her meats from another store, you know what I'm saying, because I don't like these people "beef," I don't like their chickens or whatever so you go over there and get this. So on any given day, a meal might come out of three stores but that's how we basically shop. And then they used to have vendors, fruit vendors that came in the neighborhoods and you also had an old fashioned milkman that delivered milk and she had "credit" with these people. You know, like dairy products, milk ice cream, butter and eggs - she would get that from the milk truck. Fruits and vegetables, she had credit with the guy that had fruit truck that came in the neighborhood a couple of times a week. ${ }^{26}$

The Colored Town neighborhood food system was not just prolific but was well

attuned to the intercultural foodways that emerged in the growing connections between

African Americans and Caribbeans. Former resident George Littlefield notes,

here on $14^{\text {th }}$ Street, I used to buy practically all my groceries here. Good lamb chops, lamb shanks. [...] The neighborhood grocery stores, they had plenty of that, the ingredients for the souse and all that other stuff. You had the fish markets, a big thing, [...] the Caribbean boiled fish and smothered fish and that sort of thing, that was all germane to this area."${ }^{27}$

\footnotetext{
${ }^{25}$ Herman Dorsett, interviewed by Stephanie Wanza, 21 August 1997, Tell the Story Collection, Black Archives.

${ }^{26}$ Edward McKinney, interviewed by Yvonne Daly, 7 August 1997, Tell the Story Collection, Black Archives.

${ }^{27}$ George Littlefield, interviewed by Electra B. Ford, 25 August 1997, Tell the Story Collection, Black Archives.
} 


\section{White Entrepreneurship in Food}

In 1898, Jacob Engler migrated to Key West from Romania at the age of fifteen. Engler eventually moved to the Bahamas where by the age of 30 he became a real estate developer millionaire. During the mid-1910s, Engler caught word of South Florida's growth and relocated his investments to Miami. He quickly formed close ties with elites from the Jewish community, such as Isidor Cohen, one of Miami's first Jewish arrivals and President of the predecessor to Miami's Chamber of Commerce. Engler purchased property from Cohen and moved with his wife, Minnie, into a home on the corner of $5^{\text {th }}$ Street and Northwest $2^{\text {nd }}$ Avenue, just one block south of Colored Town's southern border (Miami Metropolis 1916; Miami News 1945). Having made his fortunes in the Bahamas, Engler was determined to fetch new profits in the majority-Bahamian Black community that began steps from his front door. In 1921, he opened a public market two blocks from the community's Lyric Theater, on a strip that soon became known as "Little Broadway." Engler placed ads in the Miami News seeking "hustlers", or vendors, for his market, or what he called "A city in itself with 64 independent stores" (see Figure 3.5). Of the many vendors listed in the 1922 Miami city directory who sold staple groceries, meats, fruits, soft drinks, and sweets in Engler's public market, not one of them was Black. Whether this was intended or happenstance, the story of Engler reveals the racialized double standard of conducting business in Miami under Jim Crow.

To only comment on the prosperity of Black-owned businesses would be to miss half the picture. While Black entrepreneurs took advantage of the physical racial separation ordained by segregation to develop their own neighborhood clienteles, many whites viewed Black neighborhoods as prime real estate for entrepreneurship. In 1915, 


\section{BUSINESS OPPORTUNITY 13}

MR NI'SINESS HI'NTER-Hero is a chance for any hustler with small capital in any line, which he may be suitable to make a success and be independent with small rent. Appiy J. Engler's nublic market. A clty in itself with 64 independent stores. Old Ave. G and 2nd St., new $\mathrm{N}$. W. 2nd Ave. nnd 10th St.

Figure 3.5: Engler's advertisement in the Miami News, October 25, 1921.

responding to the mounting presence of white-owned property and businesses in Colored Town, the Colored Board of Trade, a group of leading Black businessmen, wrote an "Open Letter to the City Council" in the Miami Herald requesting that "separate but equal" did in fact keep whites and their monies out of Black neighborhoods. Another commentary in the Herald read: "we left our former places of business and located in the section marked off for colored people; since that time we have not transgressed the line. ... Can the same be said of the white citizens of Miami?" (cited in Connolly 2014, 35).

Indeed, the double standard of Jim Crow allowed white entrepreneurs to locate their businesses right inside the Black community. In particular, it opened opportunities for "white" immigrants seeking to claim a piece of the American pie but discriminated against by native-born whites. A City of Miami directory shows that as early as 1922, whites operated nearly a third of the food businesses in Colored Town. The large majority of these businesses were run by Jewish immigrants whom were excluded from 
many of the social, political, and economic dimensions of native-born white-dominated society. Historian Melissa Shell-Weiss writes, "Jews were most likely to settle and own and operate businesses in areas where there were already other Jews ... or in areas of the city that were considered 'less desirable' and therefore relatively low cost and less highly contested" $(2009,114) .^{28}$ Not being allowed to own land in Eastern Europe, many Jews learned to do business as merchants and traders. Upon their arrival to the US, many Jews were excluded from jobs, especially union jobs, and so turned to self-employment as their path toward upward mobility. They often located businesses in Black neighborhoods, one because anti-Semitism and anti-immigrant sentiments would have narrowed their clientele in white areas and also because they did not typically harbor the racist attitudes that native whites had (Lee 2002).

As the decades rolled on, immigrants from Eastern Europe and East Asia would play an active role in shaping Overtown's food landscape at the same time that their businesses gave them an economic foothold in wider society. ${ }^{29}$ According to my research, between 1922 and 1935, the number of non-Black-owned grocery stores in Colored Town doubled while Black groceries only grew by 15 percent.

White-owned groceries outside of Colored Town also attracted Black residents. As historian Juliet Walker writes in her important work, The History of Black Business in America, "the quality of merchandise offered in Black business districts ... was almost always decidedly inferior.... The lack of access to credit defeated Black merchants. Few

\footnotetext{
${ }^{28}$ In her book, Shell-Weiss discusses how anti-immigrant sentiments among Miami' s predominantly white and Christian citizenry foreclosed many business opportunities for Eastern Europeans and Asians. Thus, many of these immigrants located their businesses where they saw a viable clientele.

${ }^{29}$ In 1927, following the US Supreme Court decision of Gong Lum V. Rice, 275 US 78, the Chinese were actually racialized as "colored" and were restricted to live and work in areas designated for Blacks.
} 


$\begin{array}{lll}\text { Type of Business } & \text { Black-owned } & \text { Not Black-owned } \\ \text { Confectionery } & 4 & 0 \\ \text { Fish Market } & 7 & 3 \\ \text { Fruit Market } & 4 & 0 \\ \text { Meat Market } & 1 & 1 \\ \text { Grocery Store } & 38 & 28 \\ \text { Restaurant } & 23 & 7 \\ \text { Total } & 77 & 39\end{array}$

Table 3.1: Food businesses in Colored Town, 1922. Based on 1922 City of Miami directory.

could obtain credit from wholesalers, which would have enabled them to increase the quantity and quality of goods sold" (1998). With a competitive advantage over access to capital, white grocers were better poised to purchase large volumes of food and the refrigeration technology that would become the standard for larger groceries and supermarkets.

In the 1920s, self-service grocery stores like Piggly Wiggly and the Great Atlantic \& Pacific Tea Company, or A\&P, first opened in US cities. In Miami, by the early 1920s several larger grocery stores as well as regional and national chains were located just outside the boundaries of Overtown, and these stores, which could usually outcompete Black mom-and-pop groceries, at least in terms of price and variety, would continue to lure working-class Blacks conscientious of their budgets. As one former resident described,

there were supermarkets on the outer edges of the Black community: Margaret Ann [acquired by Winn Dixie in 1949], A\&P, places like that... they were supermarkets. That's like going to a Publix or Winn Dixie in lieu of a mom and pop store. See, we couldn't carry roasts and hams and turkeys and all that in the little grocery store we ran. If people wanted that type of stuff, they had to go somewhere else, and because of what we had 
to pay for it to get it, our prices would obviously have to be higher to the people. So when they got the bulk of their money, they would go to the supermarket to buy the bulk of their groceries, and they, because they needed a can of beans and a can of milk, then they would go to the little neighborhood store to supplement their groceries. ${ }^{30}$

Other former residents also remembered the cheaper priced goods offered by larger food markets across the tracks: "Well, naturally the neighborhood store's prices were always higher. So like on the weekend, my dad would walk to Fifth Street, you know across the railroad, and a lot of people went there... and some of them would take the little boys - they all had red wagons - and would pull the wagon with groceries." ${ }^{31}$ Similarly another recalls frequenting white groceries:

My grandmother, [...] often bought groceries from Tip Top. [...] we would cross the railroad tracks and go from our house to Tip Top which was a big grocery store ... I think I heard that that was a forerunner for Winn Dixie from what I understand. [...] in I guess the late 40s early 50s, [...] Saturday evenings after the sun set, we would, my grandmother, aunt or aunts and I would head north. Our first stop would be on First Place and Fifteenth Street to Stewart's Market. Mr. Stewart [...] had a market in which he sold chickens, poultry and fish and my grandmother would put in her order for the chickens and he would dress them and we would head north to Shell's and then Fredericks. She would buy some groceries at Shells, which at the time was on Northwest Seventh Avenue and FiftyEighth Street and then she would buy other groceries at Frederick's which was on Sixty-Second and Sixth Avenue, and on our way home we would stop back and pick up the chicken and fish. [...] Mr. Stewart's market was Black-owned, [...] but Shell's was white-owned and, of course, Frederick's was white-owned as well. ${ }^{32}$

\footnotetext{
${ }^{30}$ Ralph McCartney, interviewed by Devon Williams, 14 August 1997, Tell the Story Collection, Black Archives.

${ }^{31}$ Leome Culmer, interviewed by Stephanie Wanza, 13 August 1997, Tell the Story Collection, Black Archives.

${ }^{32}$ Herman Dorsett, interviewed by Stephanie Wanza, 21 August 1997, Tell the Story Collection, Black Archives.
} 


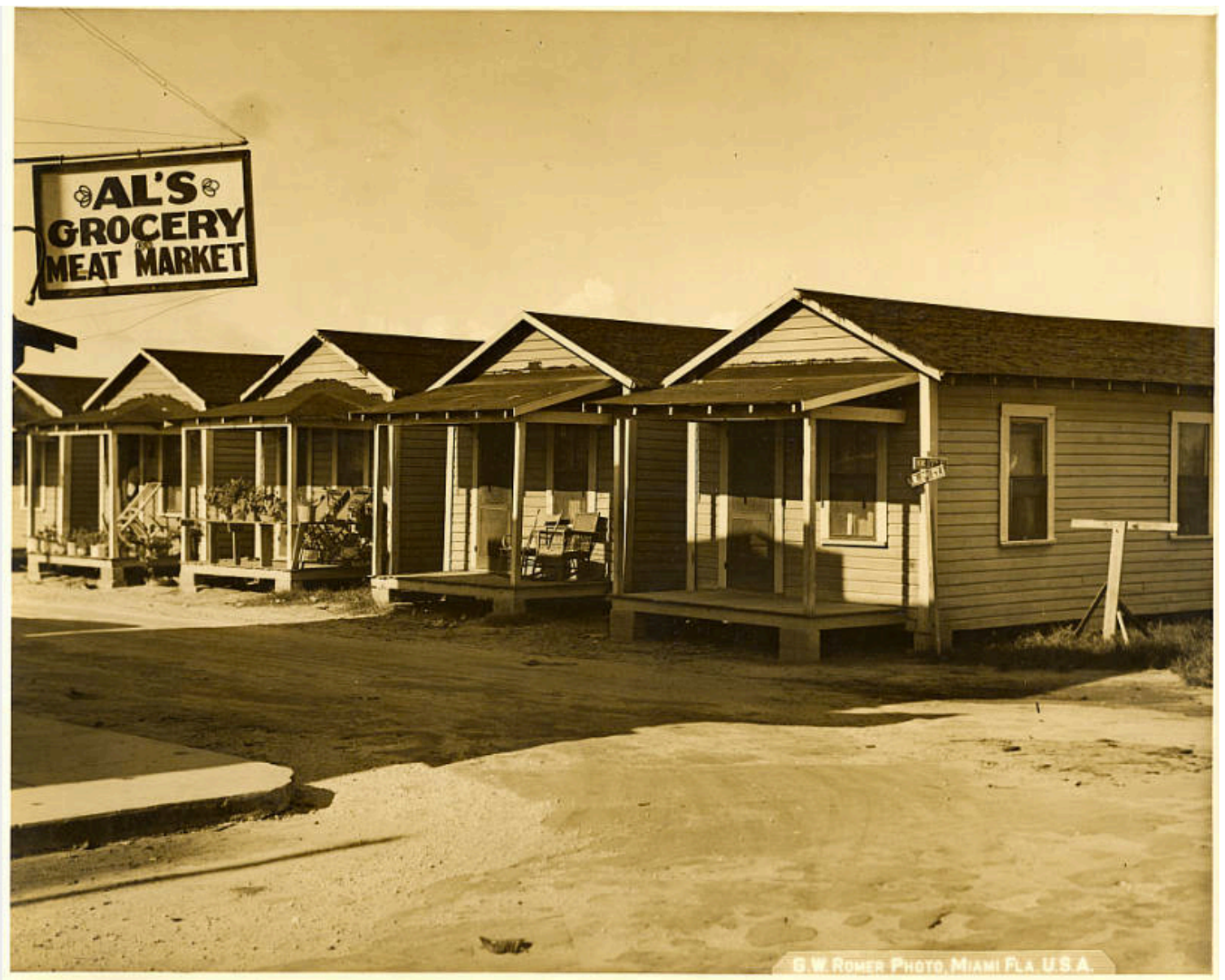

Figure 3.6: Meat market across the street from a section of row housing. Titled "Frame houses of Overtown." Reprinted from Florida Photograph Collection, University of Miami Libraries, Special Collections.

Whites also commanded the substantial food supply and distribution industry that surrounded the Colored Town's perimeter. Based on my analysis of listings in city business directories, located just one block outside the neighborhood's northern, southern, eastern, and western boundaries were dozens of white-owned wholesale distributors, dairy and egg farm companies, soda bottling plants, and commercial bakeries. In the 1920s, City of Miami officials zoned Colored Town and its immediate surroundings as "industrial" as a measure of racial zoning intended to create a physical 
buffer between Black and white housing and protect the pecuniary values of white homes (Connolly 2014, 41). Though it was zoned for industry, in practice Colored Town lacked any industrial or commercial-sized businesses, save for the Cola Nip Bottling Company and a few wholesale food dealers. In a sea of wooden tenements and small retail shops, most of the very few larger buildings in Colored Town were dedicated to churches, theaters, hotels, and the fancier homes of more affluent Blacks. Black groceries, restaurants, and other food-related enterprises thus relied on the white-dominated food industry sector to supply their businesses.

All together, white food enterprises were able to profit from segregation in multiple ways: by setting up shop in Overtown and directly competing with Black-owned stores, by establishing larger groceries just across Overtown's boundaries, and by dominating the wholesale and distribution sectors on which Black food businesses relied. As was the case elsewhere in the US, relations between non-Blacks and Black Overtown residents ran a spectrum between harmony and hostility, although they could become increasingly tense during times of economic hardship for Blacks. For example, in the early 1920s, Marcus Garvey, leader of the Universal Negro Improvement Association who held significant influence in Miami, urged his constituents to "buy Black," emphasizing that racial uplift necessitated overcoming white, particularly Jewish, dominance in business in Black communities. Sociologist Jennifer Lee (2002) writes that Jewish merchants were commonly viewed as entrepreneurial role models for African Americans during the 1920 s, only to be later viewed as dominators of commercial competition and extractors of wealth from the Black community. Tensions across the country were exacerbated between the 1940s and 1960s as economic progress for Black 
merchants lagged far behind their Jewish counterparts. In the fifties and sixties, Cecil Rolle, born in Miami to Bahamian immigrants, led a series of boycotts against white merchants who marked up prices on cheap goods and denied Blacks consumer credit (Connolly 2014, 231). Public protest, however, was routinely criticized and discouraged by Miami’s Black political leaders who, in calling upon a politics of respectability, instead advocated for more accommodationist means towards racial progess. Connolly writes, “One black Miamian wrote the following in rebuke of Rolle's 1963 boycott of a white ice cream shop: "Mr. Rolle does not realize the many wonderful friends white businessmen make in Negro communities" $(2014,232)$.

At the same time, oral history accounts describe some favorable impressions of non-Black entrepreneurs who did business across the color line. Said one resident, "Mr. Cohen would come by and wave and speak. They would come open their place in the morning, so if anyone needed a cold drink, or a cold soda, or cold ice cream, or whatever, a nice hot biscuit and grits, it was always available. And they made you feel so welcome when you came in. They wanted you to come, not just get your money, you know, you felt welcome." ${ }^{33}$ When it came to food, because of the competition, business owners had little choice but to provide food that was culturally appropriate and reasonably priced. One Greek immigrant ran a restaurant that had "sweet potatoes up in the window and them old ham hocks and pigtails and pig foot ... My grandpa use to go there, eat in there

\footnotetext{
${ }^{33}$ Norma Jean Walker, interviewed by Aldo Regalado, 8 July 1999, Gregory Bush Community Studies Oral Histories, University of Miami Libraries Digital Collections.
} 
I think [for] fifty cents (laughter). But you got a good meal, you know, and I mean life was hard for the poor people, but you didn't feel like it." ${ }^{34}$

In some cases, non-Black business owners met their customers halfway economically, allowing them to purchase goods on credit and repay their debts interestfree weeks later. This, too, was happening in other major US cities, which often "allowed them [Blacks] to lift their standard of living, partake in the consumerism of American culture, and benefit from some of the goods enjoyed by the middle class" (Lee 2002, 27). As one Overtown resident recalled, "we lived about two houses from what was known as Speigelman's grocery store. That was a Jewish grocery store on the corner where he credited everybody and everybody paid him whenever they [...] could afford to., ${ }^{, 35}$ Similarly, "the Chinese had several grocery stores in Overtown, [...] and they also permitted people to credit." ${ }^{36}$ Evidence also suggests that some immigrant businesses employed local residents: "I worked [...] at another grocery store in our neighborhood, Joe's Market [...] Joe's was owned by a Chinese family and [...] I worked as a little clean up kind of kid there." 37

These accounts reveal Overtown's early business environments to be a more ethnically and racially complex community than some historical accounts of Jim Crow detail. While residential patterning may have followed strictly with racial segregation

\footnotetext{
${ }^{34}$ Peggy McKinney, interviewed by Alex Milfort, 14 August 1997, Tell the Story Collection, Black Archives.

${ }^{35}$ Benny O'Berry, interviewed by Electra B. Ford, 11 August 1997, Tell the Story Collection, Black Archives.

${ }^{36}$ Enid Pinkney, interviewed by Stephanie Wanza, 5 August 1997, Tell the Story Collection, Black Archives.

${ }^{37}$ Herman Dorsett, interviewed by Stephanie Wanza, 21 August 1997, Tell the Story Collection, Black Archives.
} 
mandates, Black communities like Colored Town were far from off limits for non-Black entrepreneurs and capitalists. Drawing from city business directories and 1921 Sanborn

Fire Insurance maps (which portrayed the original street grid), I illustrate the spatiality of Black and non-Black food businesses in the neighborhood in 1940 (see Figure 3.7). Not only are these businesses spread throughout the neighborhood, as opposed to being confined to specific commercial districts, we can also see how businesses categorized as "colored" were relatively evenly distributed among those that were not. In this year, whites, both American or foreign-born, owned more groceries than Blacks and nearly half the total food businesses. This map complicates popular narratives of Overtown's “heydays," and legal segregation more generally, as racially "separate but equal," instead pointing a world of interracial tensions, exchanges, and connections.

\section{Food and Place-making}

In this chapter, I have used food as a lens to understand the kind of place Colored Town residents were making during legal segregation in the early and mid-twentieth century. On the one hand, the combination of racial segregation, dense housing, minimal resources, and the biological imperative to eat brought Colored Town's diasporic Black residents into close contact. In the intimate spaces of their homes and neighborhood blocks, residents forged bonds with one another, creating networks of care that crossed lines of nationality, ethnicity, and even class. In so doing, they exchanged and improvised upon foodways rooted in West African, Caribbean, and African American traditions.

Residents also developed scores of food businesses, drawing from skills acquired through generations of working on rural farms and plantations as well as a spirit of 


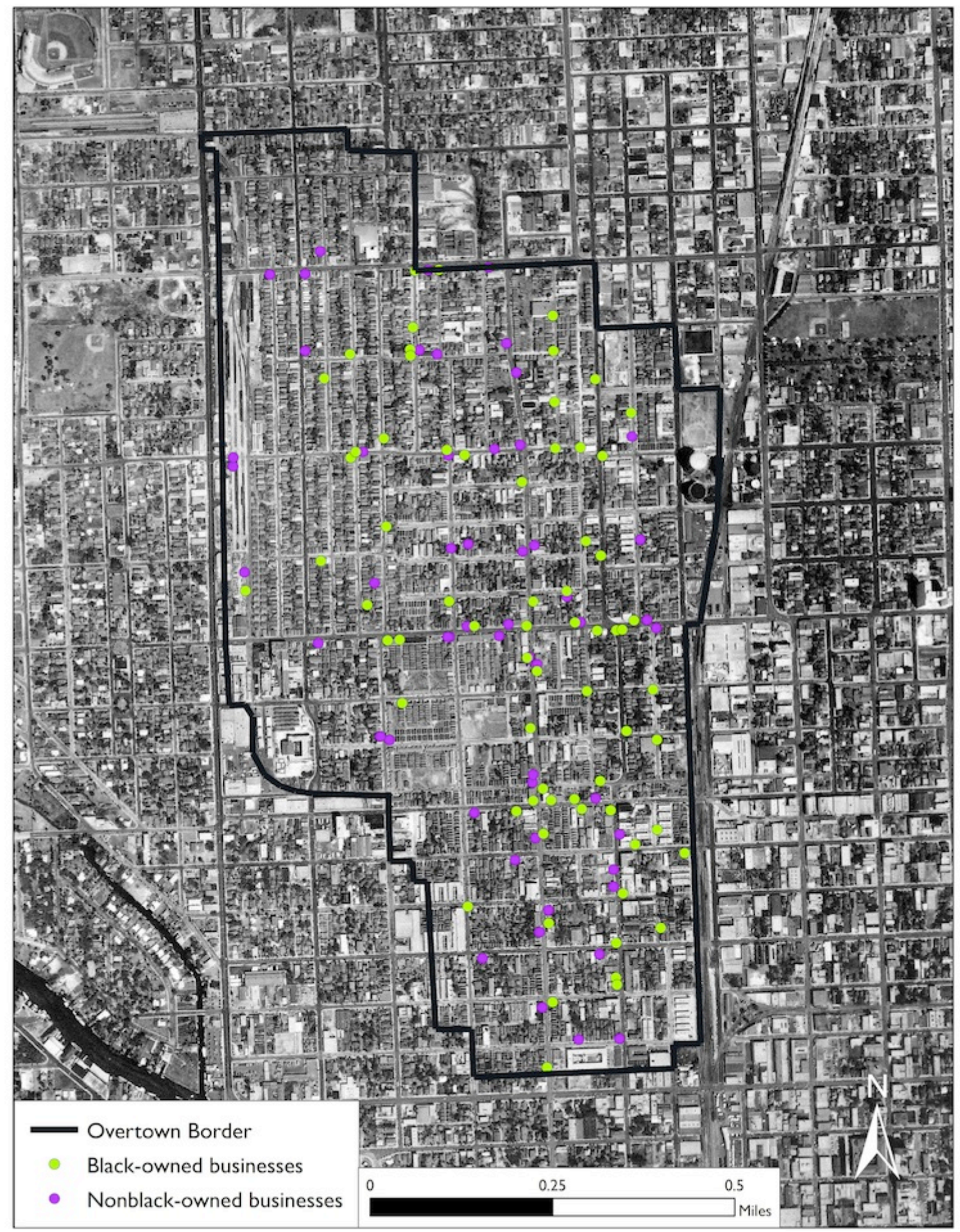

Figure 3.7: Black- and white-owned food businesses in Colored Town, 1940. Source data from Miami City Directory, 1940; USDA Aerial Photographs, National Archives, Washington, DC, 1952. Map by author. 
entrepreneurship circulating across Black America. These businesses enabled residents to making something out of nothing, to invest meager sums of capital into building a livelihood around nourishing one's community. The vast majority of Blacks had no real opportunities to own property and acquire wealth, making business ownership the next best thing to achieve a sense of economic independence. Just as slaves used their owner's land to grow food for themselves and self-determine a piece of their material existence, so too did residents of Colored Town use property in their segregated community to operate groceries, markets, restaurants, bakeries, and other businesses as a means of selfdetermination and autonomy.

Certainly some of these businesses failed or were short lived. Others were stepping-stones for further entrepreneurial pursuits. These businesses, however, played a vital role in the development of a separate Black economy and challenged the dominant social and economic order of Jim Crow. Like elsewhere in the South, white supremacy underpinned the operation of capitalism and wealth creation in Miami, laying a hierarchical structure for maximizing the extraction of profit from Blacks, both as tenants and as an always accessible pool of reserve labor. To some extent, Black entrepreneurship disrupted this project because starting a business removed one, at least partially, from the labor pool, placing them further from the grip of white-dominated capitalist production systems. Business ownership provided a means of re-escaping the plantation, what Clyde Woods called "the basic site of production from which the global racial capitalist system was built" $(1998,27)$, and resisting the "plantation logic" Katharine McKittrick (2013) argues was extended to and spatially expressed within postslave urban contexts. If we take McKittrick's idea seriously, then Flagler's railroad 
delivered the plantation blueprint from the rural US South to south Florida, installing a spatio-economic system predicated on racial segregation and violence to contain Black bodies and control Black labor. But contrary to white supremacist spatial visions for Jim Crow Miami, which sought to divorce Black place-making from capital accumulation through the dispossession of property and the means of production, Black enterprise collectively worked to assert place-making as a spatio-economic practice.

Most of the oral history accounts describe a "closeness" that developed among residents and entrepreneurs making life in the crowded spaces of Colored Town, a closeness that contrasts the displacement, separation, and fragmentation of Overtown's Black community that would later result from urban renewal and interstate highway construction projects, as I describe in the next chapter. As former resident Christelle Roach recounts:

[W]e had everything that we needed right there in the community and didn't have to go too far to get all of our services and our goods... We lived where we shopped... there was a closeness. I think after we became so dispersed in Miami ... and moved to so many areas, the community idea, the community feeling began to disintegrate... It was no longer the hub or the veins of that body of people that lived there, the veins that fed the people, that clothed them, that took care of their needs. ${ }^{38}$

In effect residents of Colored Town achieved what was supposed to be impossible: "the actual growth of narratives, food, and cultural practices that materialize the deep connections between Blackness and the earth and foster values that challenge systemic violence" (McKittrick 2013, 10). Such a process re-territorialized Colored Town into a space where life could take place beyond the brutal indignities inflicted by Jim Crow's

\footnotetext{
${ }^{38}$ Christelle Roach, interviewed by Ivonne Daly, 22 August 1997, Tell the Story Collection, Black Archives.
} 
racial order and alternative futures of communal existence could be imagined and worked for. 


\section{MOM AND POP STORES DON'T HAVE NOTHIN' ON THE BIG STORES: TRANSFORMATIONS IN OVERTOWN'S FOOD LANDSCAPE}

It was like no black community in the South during ... the days of segregation. You either was self-sustaining or you went without until you became self-sustaining. Well, they were, and segregation was an ugly thing and I don't want it back, but it did make us much more aware of who we were than what we are now with integration, because a lot of us are just as lost as all door is open, see.

- Irby McKnight, Overtown resident ${ }^{39}$

Integration helped in one sense. We got to go to the areas where we wanted to go. We got what we wanted, but we lost what we had.

- Georgia Ayers, community activist ${ }^{40}$

\section{Eminent Domain}

By the 1950s, the square mile that made up Miami’s Central Negro District was virtually a small city in and of itself, with its African American and Afro-Caribbean population comprising more than 40,000 residents. A 1961 City of Miami report reveals that, in an area where buildings taller than two stories were rare, on average some 48 housing units were crammed onto an acre of residential land, housing an average of 136 people (see Figure 4.1) (City of Miami 1961). In some areas, more than 600 people lived on a single acre. Unsurprisingly, the conditions were often deplorable. Most homes lacked indoor plumbing and many were without basic electricity, as landlords were far more concerned with extracting rents than providing adequate living conditions.

Miami's urban landscape laid bare the polarized conditions on each side of the Jim Crow color line:

\footnotetext{
${ }^{39}$ Quote from the Black Archives public forum at the Joseph Caleb Center, 7 August 1997, Tell the Story Collection, Black Archives.

${ }^{40}$ Quote from documentary, The Hampton House Motel: An Oral History Collection, produced by the Historic Hampton House Community Trust.
} 


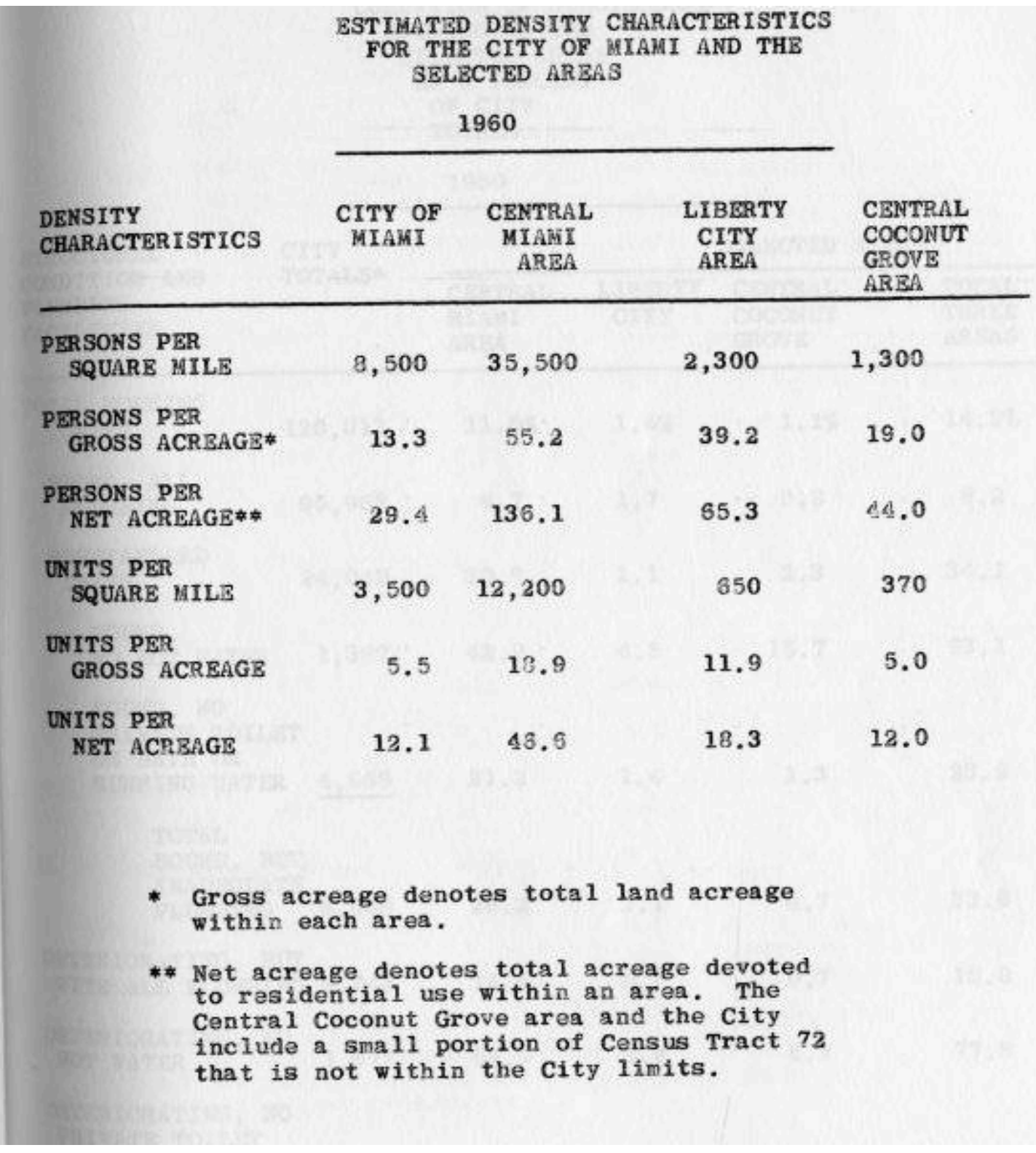

Figure 4.1: Residential density in the Central Miami Area (Central Negro District) and other neighborhoods. Reprinted from "A Comprehensive Analysis of Miami's Neighborhoods, City of Miami," 1961, Florida International University Green Library, Digital Collections.

On one side of the Florida East Coast Railway tracks stood a modern downtown built of white concrete, with stucco finishes, marble accents, and fresh paint. On the other side, a less bright city, still largely made from wood, represented an earlier age. Reflecting the midday Florida sun, Miami's downtown literally shone "white" next to its darker neighbor. (Connolly 2014, 219) 
In the context of postwar prosperity, the slum conditions of the Central Negro District at the edge of downtown Miami were increasingly viewed by white business elites as an embarrassing visual detraction to the city's primary industry, tourism, and its popular branding as the modern "Magic City." With the politics of desegregation intensifying, locally and across the nation, the imperative to modernize Miami's physical environments became increasingly intertwined with dismantling Jim Crow racism and replacing it with a less overt, though still institutionalized form. In 1954, the same year of the landmark Brown v. Board of Education decision, the federal government established the urban renewal program, and two years later the Federal-Aid Highway Act was passed. Through these initiatives, the federal government would subsidize ninety percent of costs for demolition and highway construction as well as two-thirds of costs for slum clearance and infrastructure developments in eligible cities.

Proposals to link Miami to the nation's interstate highway system and "connect South Florida's growing suburbs, its center cities, its beaches, and its airports" (Connolly 2014,214 ) were first designed in the late 1950s. Each of these proposals included plans for Interstate 95 bisecting east-west expressways that would run directly through the Central Negro District. For example, an illustration in the 1960 Magic City Center Plan for Action, a joint city and county blueprint, places the expressway loop right in the heart of the neighborhood (conspicuously rendered invisible in the image below as if to symbolize the deliberate intention to clear the community [see Figure 4.2]). A section of the plan, titled "Urban Renewal," reads: 


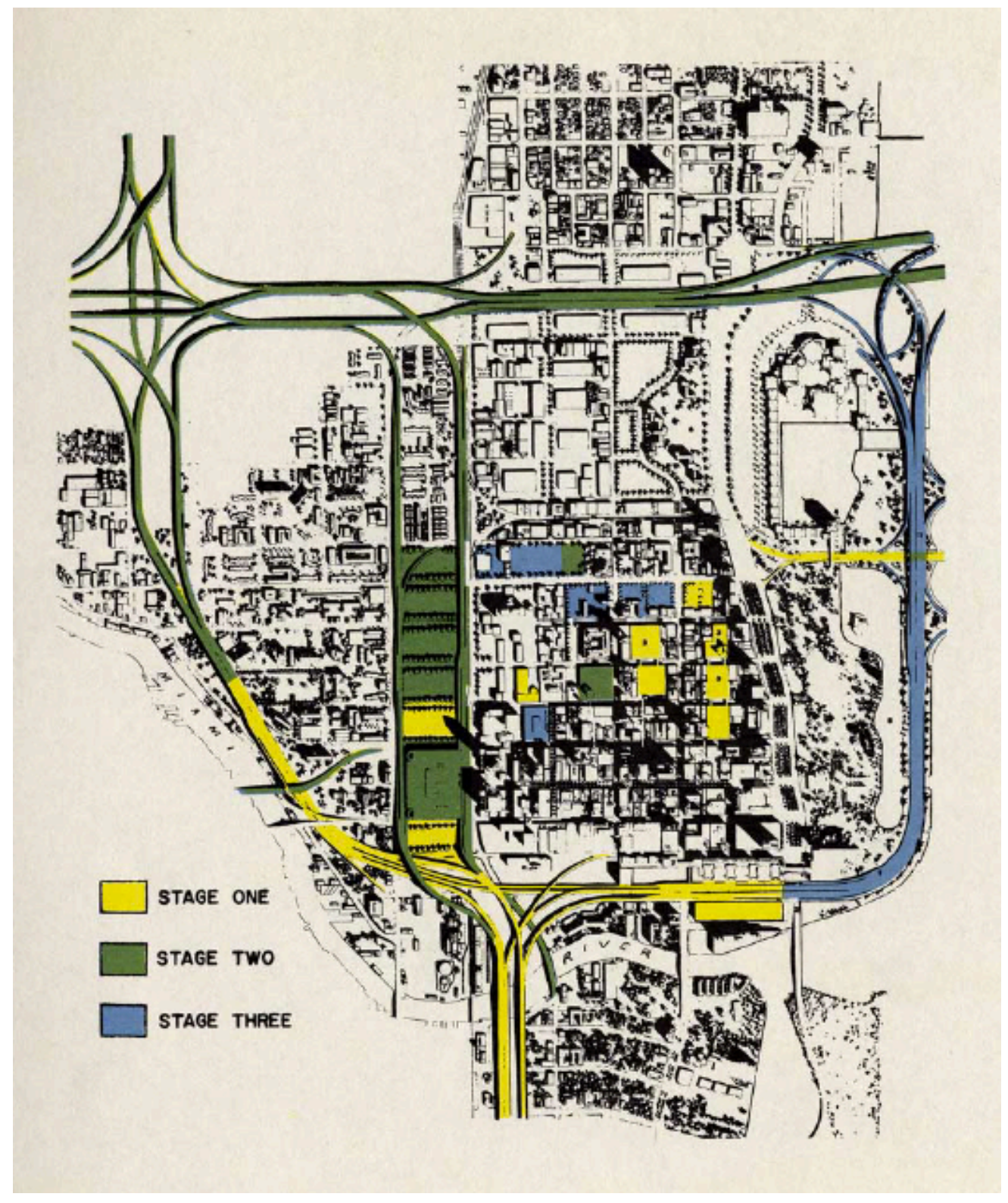

Figure 4.2: Transportation infrastructure plan. Reprinted from "The Magic City Center Plan for Action, Metro Dade Planning Department," 1960.

Usually people are surprised to discover that the beautiful resort city of Miami has blighted and dilapidated areas - some of which are on the very fringe of the Central Business District ... If efforts to pump new economic life into the downtown core are to succeed, these budding slums must be demolished and new commercial and residential enterprises must rise from the debris ... The section of the CBD most likely to qualify for federally assisted urban renewal lies west of the FEC Railroad tracks and north of North Fifth Street. (Metro Dade Planning Department 1960, 52) 
As Connolly (2014) details in A World More Concrete, implementing the nearly wholesale destruction of the Central Negro District was not so much a top-down imposition of government policy as it was a negotiation between those white business elites and leaders of Miami's Black communities with overlapping interests in erasing the vestige of Jim Crow. By the late 1950s, most who could afford to move out of the Central Negro District did. The area had become rife with structural deterioration, unemployment, street crime, vermin infestations, and disease. Thus, the prevailing spatial vision of desegregation through inner city condemnation did not wholly conflict with the dreams of ordinary Blacks either. Though often proud of the community they had built, many Blacks saw its deplorable physical conditions as a living monument to white oppression. The promise of home ownership in Liberty City and other suburbs was imagined as an emancipating future from a life of oppressive tenancy. Resistance to slum clearance, then, came less from residents of the Central Negro District than it did from those landlords seeking to protect their interests in rental capitalism. However, in 1959, a Supreme Court of Florida decision allowing slums in Tampa to be condemned within designated urban renewal zones set a precedent for using eminent domain to trump private property interests for the "public good." Landlords were forced to accept that most of the shotgun houses they owned would be torn down, yet still received handsome payouts.

Though delayed until 1965, once expressway construction and demolition projects began, they were implemented swiftly. The combined impact of forced displacement by eminent domain cannot be overstated. Some rounds of urban renewal leveled areas as large as ninety-seven acres in one fell swoop (Lowe and Ferguson 1983). Amidst the 
massive condemnation, the slow construction of new tenement housing, and the lingering hopes of racial liberation through home ownership, thousands of Black residents and entrepreneurs dispersed to the edges of the City of Miami and into the sprawling suburbs of Miami-Dade County, in "second ghetto" neighborhoods like Liberty City, Opalocka, Miami Gardens, South Miami and Richmond Heights, leaving some of the most destitute behind in the community that would become known as Overtown. ${ }^{41}$ Over the span of a decade, the population of Miami's Central Negro District halved from 40,000 to 20,000 or less, and "[s]eventy per cent of its businesses became vacant, boarded-up storefronts" (Grimm and Bearak 1980,2B). Between 1966 and 1967 alone, the number of businesses in Overtown decreased by twenty-three percent, "the largest single year decline in the neighborhood's history" (Feldman 2011, 51). By 1970, a total of 430 businesses had been forced to relocate. In Figure 4.3, I map the locations of Overtown's remaining food businesses after slum clearance and the placement of the expressways gutted nearly half of Overtown's available land space. We can see how most of the businesses became confined to two north-south corridors (Second and Third Avenues) on the eastern side of Overtown, spatially separating residential from commercial life. Raymond Mohl would later write, "By the end of the expressway building era, little remained of Overtown to recall its days as a thriving center of Black community life, when it was widely known as the "Harlem of the South"” (Mohl 1993, 75-76).

\footnotetext{
${ }^{41}$ Overtown began to receive its name from residents who had left the Central Negro District and would have to travel "over town" to make visits.
} 


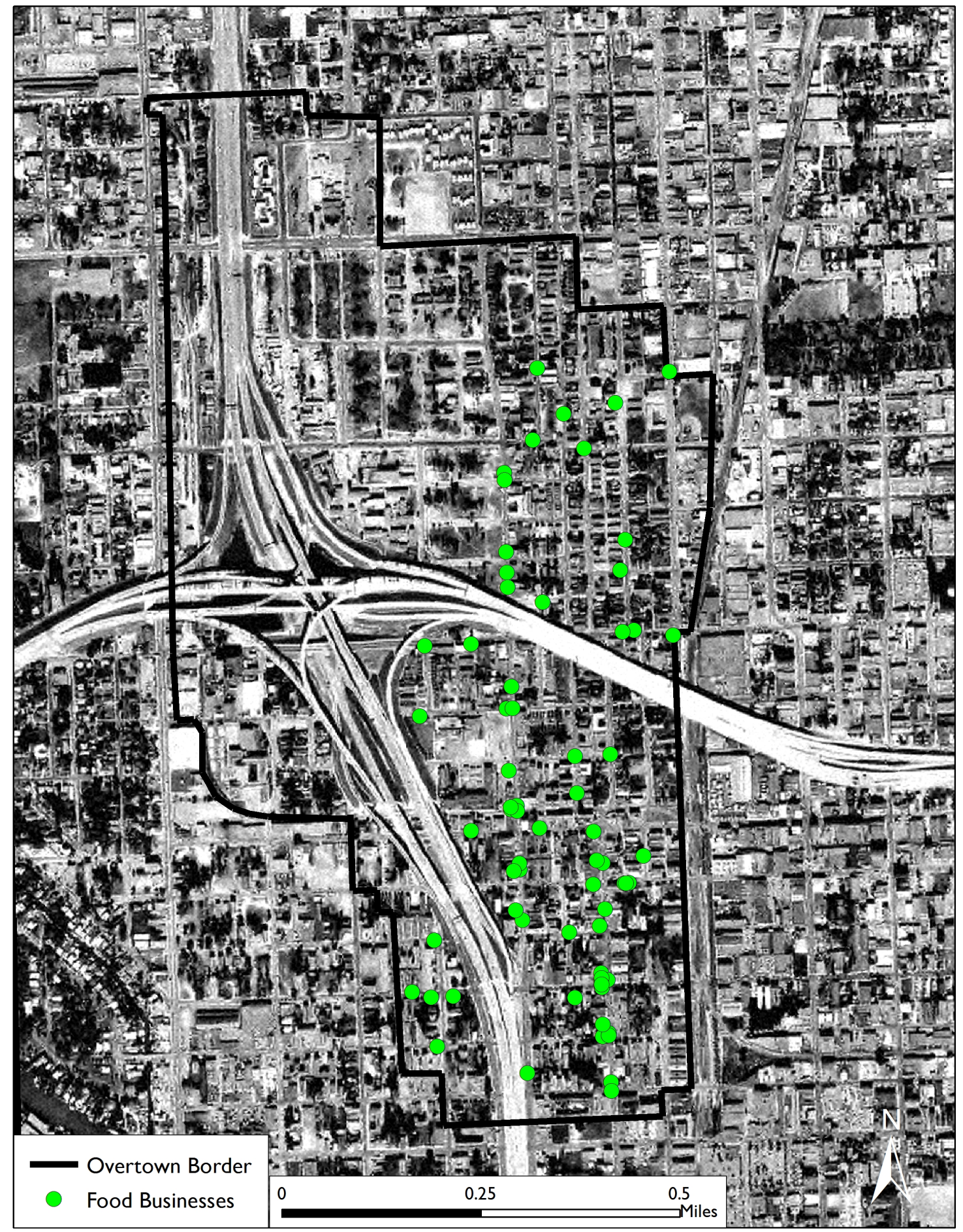

Figure 4.3: Locations of food businesses in Overtown following the construction of the I95/I-395 expressway, 1970. Source data from Miami City Directory, 1970; USDA Aerial Photographs, National Archives, Washington, DC, 1970. Map by author. 


\section{Immigrant Domain}

Desegregation and the fragmentation of Miami's Black community also coincided with the beginnings of a social, political, and economic transformation that would forever change the conditions for Black progress. Following the Cuban Revolution of 1959, an exodus largely comprising members of Cuba's well-to-do entered the US, mostly settling in Miami. By 1962, between 1,500 and 2,000 Cubans were arriving to the US each week. Following the failed Bay of Pigs paramilitary invasion to overthrow Fidel Castro, in addition to a series of thwarted attempts of his assassination, Miami's Cubans decided to stay. As exiles from communist Cuba in the context of Cold War geopolitics, the earliest waves of immigrants were treated like no other immigrant group in US history, enjoying $\$ 1.3$ billion in federal assistance and a relatively seamless path to permanent residency through the Cuban Adjustment Act and Cuban Refugee Program of the 1960s (Zucker and Zucker 1996).

As a privileged class in their homeland, Cubans did not identify as minorities, at least racially, and did not seek to unite with Miami's actual marginalized populations. Shell-Weiss writes, “ Unlike Los Angeles or Houston, where critical Black-brown alliances were formed among African Americans and Latinos, the particular demographics of Miami’s immigrants and the southern norms they encountered cause distinct Black-white divides to remain in place even as the city became more international and more ethnically diverse" $(2009,8)$. That Cubans were by and large disinterested in the civil rights movement - and possibly even hindered interethnic coalition building around civil rights in Miami (Mohl 1999; Shell-Weiss 2009) - is ironic considering the ample gains they received as a result of its efforts. Because of the many 
Blacks who marched and protested in the South for civil rights, Cubans and other Latino immigrants were categorized as "minorities" and benefitted from 1960s equal opportunity and affirmative action policies. They were also fortuitously eligible - if not often deemed more eligible - to apply for the same minority business loans and grants as Blacks. A 1981 newspaper reads: "Of the 100.5-million lent in Dade County by the Small Business Administration from 1968 through 1979, \$47.3 million went to Hispanics, \$46.8 million to whites, $\$ 6.4$ million to blacks. While Dade's black population is about 50 percent that of Hispanics, blacks got only 13.6 percent as much money" (Porter and Dunn 1981). Similarly, a 1980 Miami Herald article laid bare the racial polarization in US business: "Black Americans do not share the nation's bounty. And black entrepreneurs feel cut off from risk capital which whites, and even alien whites, enjoy to the full. [...] The social cancers breeding black despair are enormously costly to eradicate, if they can be eradicated at all. As one black professional tells me: 'We would need something on the scale of the Cuban exile assistance program to come to grips with it"' (Whited 1980,2B). In 1986, an article published in American business magazine, Inc., read: "Perhaps no American city so epitomizes the problems faced by blacks and black business as Miami. Miami's is a booming economy in a booming region. And as in so many cities, Miami blacks have had to watch as other, newer minority groups have come along and passed them by on the road to economic security and prosperity" (Kotkin 1986).

And so, bestowed with unprecedented resources during the postwar growth of a relatively new city, Cubans began to quickly transform Miami's economic prowess. Instead of seeking incorporation into the mainstream, white-dominated business and political milieu, affluent Cuban exiles used their professional skill sets and social 
networks to design their own parallel institutions, organizations and businesses. They collectively channeled their resources to take control of the local political structure and to advance their own conservative and international agenda, a fact well documented by researchers of the "Miami school" of immigration (Portes and Stepick 1993; Stepick et al. 2003). They developed industry sectors that strengthened Miami's hemispheric connection to the Caribbean and Latin America and established scores of small businesses in ethnic enclave neighborhoods like Little Havana, Westchester and Hialeah (Portes and Wilson 1980; Portes and Stepick 1993).

While Cubans and other Latinos may not have intentionally taken away jobs and other opportunities from Blacks, they effectively mobilized their resources, education and personal networks to "transform the local economy in ways that relegated Blacks to a permanently subordinate position" (Sassen and Portes 1993, 473). They also "moved into enterprises formerly run by blacks" and even set up shop in black neighborhoods (Porter and Dunn 1984, 195-196). In 1987, for every Black-owned firm in Miami-Dade there were six Cuban-owned firms, "and gross sales stood in a two-to-one ratio" (Sassen and Portes 1993, 476). In that same year, just one of Dade County's banks was Black-owned while "Hispanics control[ed] 30 banks, including the Cuban-owned Republic National Bank of Miami, which has grown from a few million dollars in assets a generation ago to more than $\$ 800$ million today. That's more than the combined assets of the 9 largest black-owned banks in the entire United States" (Kotkin 1986). Scholars of Miami observed: "By the early 1990s, just thirty years after Cubans began arriving, they controlled the most important local political machinery and they had deeply penetrated the most important economic arenas" (Stepick et al. 2003, 27). They helped steer 
Miami's economic growth in tourism, real estate, international banking and small business, consolidating real economic opportunity almost exclusively within the white and Latino middle- and upper-class and leaving many Blacks to negotiate life within the shadows of prosperity.

\section{The Paradox of Desegregation}

With Overtown in a state of free fall, the future of Black business in the neighborhood looked bleak. Desegregation, as it was destructively coordinated through urban renewal, deteriorated much of Overtown's neighborhood economy and social fabric. Business networks were fractured, communities torn apart, social and human capital depleted. Future generations were robbed of the community's accumulated wealth of knowledge and ingenuity from which they could acquire the experiences, skills, and attitudes needed to earn or build a livelihood. The self-determined entrepreneurial culture and spirit that had developed over multiple generations was fast diminishing. Dr. Dorothy Fields, founder of the Black Archives and former Overtown resident, explained:

Overtown was our cradle of culture and business. It was all we had... Whether or not Overtown would have still been vibrant with integration, we don't know. It wasn't given the chance... Many of the families with businesses told their kids to study education. They said, 'If you become a teacher that's something they can't take away from you. They took our businesses from us by forcing us to move.' ... That, to me, is the worst thing. Blacks had been employing Blacks on a fairly large scale. With it went our self-determination. We lost the sense that we can do things for ourselves. (Lowe and Ferguson 1983, 1A)

One of Overtown's longtime community activists, Barbara, echoed these comments to me during an interview at one of Overtown's social services centers. She described how prior to urban renewal, 
the African American community was more united. A lot have changed since integration. A lot have changed since suburbia. And a lot have changed since the fact that we can live everywhere now and we have isolated ourselves in communities that we think was better than the communities in which we were living. But the truth of the matter is they are not. You might got a bigger house. It might be furnished bigger. But you can't go next door and borrow a cup o' sugar. So when you say that your lives are better when you lived closer together, it was a good thing because we were protective of one another. We are not protective of one another anymore and we are not perpetuating our economics. When we were together we had to support our own economics but today we don't have any. We're beggars now, which is horrible. ${ }^{42}$

Indeed, integration came with little institutional support or guidance for helping Black business compete in integrated markets. During legal segregation, most Black businesses catered directly to the community in which they were embedded and could rely on a captive, mixed-income clientele (Oliver and Shapiro 2006). Said one former resident, "One of the things created by segregation was that you had a mixed economic community; you had Blacks who were low-income, Blacks who were low and moderateincome, and Blacks who were affluent, and so you wouldn't just have to have businesses that just catered to one economic group. ${ }^{\text {43 }}$ But with Black consumers widely dispersed and legally able to access businesses beyond their communities, Overtown businesses served mostly the very destitute and even then had difficulty sustaining their patronage. Geographer Bobby Wilson writes,

In this management of black spaces, the controlled, segregated economy prevented black entrepreneurs from developing the business acumen and accumulating the capital necessary to develop large-scale economic enterprises. Thus they never achieved economic control inside the black community, nor did they gain control of very much outside the black

\footnotetext{
${ }^{42}$ Barbara, interviewed by author, 5 June 2015, Overtown social services center, Miami, FL. The names of most interviewees in this dissertation are pseudonyms.

${ }^{43}$ Doretha Nichson, interviewed by Ameenah Shakir, 30 November 2000, Gregory Bush Community Studies Oral Histories, University of Miami Libraries Digital Collections.
} 
community. In the process, the black economy did not develop the range of businesses necessary for interdependency or interlinking economic structures. $(2012,974)$

Black-owned small groceries were particularly hard hit. Not only were their local customer bases significantly depleted, but also they struggled to compete with the larger chain supermarkets that emerged in the postwar period (Seth and Randall 1999; Tedlow 1990). Du Bois warned of this just before the turn of the twentieth century:

The large industry, the department store and the trust are making it daily more difficult for the small capitalist with slender resources and limited knowledge to live... A Negro can to-day run a small corner grocery with considerable success. To-morrow however, he cannot be head of the grocery department of the department stores which forces him out of business. $(1899,25)$

After the Second World War, major technological, infrastructural, cultural and demographic changes profoundly impacted the food retail industry. With the postwar boom, America was further industrializing and urbanizing, and disposable incomes were rising. In the late 1940 s, commercial and residential refrigeration became more widely available and affordable, allowing stores to carry larger inventories and shifting consumer practices away from daily shopping towards bulk purchases (Smith 2004). This, combined with suburban sprawl - made possible via the highways - and the rapid spread of car culture, encouraged grocery chains to transform into larger supermarkets and locate their stores to more affluent outskirts of cities and high-traffic areas of the urban core (Humphery 1998; Tedlow 1990; Winson 2013). Between 1935 and 1977, the share of total grocery sales in the US commanded by supermarkets skyrocketed from 3.2 percent to 75 percent (Manchester 1992). 
By the 1950s, leading national and regional supermarket chains such as A\&P, Publix and Winn-Dixie (and the various companies the latter acquired, including Margaret Ann, Kwik Chek and Table Supply) had established a dominant foothold in Miami's food retail landscape. Though these chains were typically located outside of the poorer inner city, the variety, quality and affordability of goods they provided lured inner city residents to frequent these stores and participate in rapidly growing form of American consumerism. According to a survey conducted by the Urban League of Greater Miami (1978), seventy-six percent of Overtown residents did "their grocery shopping outside the area."

Because small businesses like corner groceries purchase small quantities of goods and pay more for insurance - for operating in "high risk" areas - competing with supermarket prices is difficult, if not impossible. Instead, Overtown's grocers in the postcivil rights era continued to rely on their competitive edge of geographic convenience, providing groceries and basic goods within a short walk of people's residences. Although the volume of sales were relatively low and profit margins narrow, running a small grocery could still be profitable considering that property values and rents in the area had hit rock bottom. Etta Thomas, for instance, who runs one of the last surviving Blackowned groceries in Overtown, described the 1970s as relatively prosperous for her business and others in the area: "The early years was the best years. Overtown was happenin'. They had a lot of businesses owned by Black.... It seems like it was a area that everybody enjoyed then, being in Overtown. I enjoyed it because I had a lot of clients, you know, clientele coming in, and a lot of people stopping by, coming in the 
area and wanted to buy something, they did." ${ }^{44}$ Etta moved to her aunt's place in Overtown from Mississippi in 1971 after graduating high school. That year she met her future husband, Eddie, a transplant from northern Florida, while working next door to him, Etta at an Overtown fish market and Eddie as a manager for a friend's independent grocery. Shortly after, Etta was hired to work with Eddie at the grocery. "After that we decided, since we know a little about business, we might as well go into business ourselves," said Etta. By 1977, the two were married and had two children, and took out a mortgage for a building just west of the FEC railroad tracks to open their own grocery. The following year they received a $\$ 25,000$ business loan backed by the county, which they repaid upon obtaining a loan with more favorable terms from the Peoples National Bank of Commerce. ${ }^{45}$ With "just a little cigar box" for a cash register, the Thomases” grocery, was earning about $\$ 200$ a day, enough for the owners to pay down the store’s mortgage, purchase annual license fees, and take home an income.

By this time, most if not all of the Jewish and Chinese storeowners present prior to the urban renewal era had closed shop, either retiring or moving on to more profitable and less laborious endeavors. As one Palestinian corner store clerk told me: "The Jewish people were here first. But they don't need this now." ${ }^{46}$ Sociologists use the term "ethnic succession" to describe the process in which racial and ethnic groups use their available resources to occupy low-income urban niches until they move up the socioeconomic

\footnotetext{
44 Etta Thomas, interviewed by author, 17 August 2016, Overtown grocery store, Miami, FL.

${ }^{45}$ Incidentally, the Peoples National Bank of Commerce became the first and only Black-owned bank in South Florida after Sonny Wright (mentioned in chapter three) purchased a controlling interest in 1983.

${ }^{46}$ Abdul, interviewed by author, 9 January 2015, Overtown grocery store, Miami, FL.
} 
ladder, at which point they are displaced by another ethnic group (see Aldrich and Reiss 1976; Lee 2002; White 1984). A longtime Overtown resident who operated a shoe repair shop for several decades described to me the transition of immigrant-owned businesses in the area, stating, "We used to have Jewish stores everywhere! Yeah... it was Jews, then the Chinese, then the Arabs." ${ }^{\text {"47 }}$ The mentioning of "the Chinese" refers to the many stores opened by Joe Wing and Joe Fred Gong and their relatives and friends. Arriving in Miami in the mid-1920s, Mr. Wing and Mr. Gong were racially categorized "colored" and relegated to live in neighborhoods designated as such. Over the course of some fifty years, the two men and their close friends and family from the Chinese province of Guangdong operated more than thirty “Joe's" grocery stores_Joe's Eighth Street Market, Joe's Fifth Avenue Market, Joe's Grocery, Joe's Grocerama-in Miami’s Black neighborhoods. Most of these stores, however, did not last long into the 1970s. As crime soared with the depressing physical and economic changes wrought during urban renewal, "almost every [Joe's] store was held up, some many times. Others were burned out in riots in 1968 and 1970. Several merchants were shot. Two were killed" (Jacobs 1986). With the phasing out of Jewish-owned and Chinese-owned stores and the passing of the 1965 Immigration Act, Overtown's grocery niche was increasingly occupied by newly arriving immigrants from the Middle East and Spanish-speaking Caribbean.

\section{Riots and Revitalization}

By the late 1970s, Miami’s Black communities had become deeply aggrieved by the dire social, economic, and political realities unfolding in the aftermath of urban

\footnotetext{
${ }^{47}$ Frank, interviewed by author, 9 January 2015, Overtown shoe repair store, Miami, FL.
} 
renewal. The dreams of racial uplift during the civil rights era had become supplanted with concrete tenement housing, failing Black businesses, mass unemployment, and rising poverty in predominantly African American neighborhoods like Overtown, Liberty City, and Brownsville, which sharply contrasted the seemingly effortless success of Miami’s growing immigrant population. In 1978, the Urban League of Greater Miami issued a sobering profile of Overtown. In their report, they found two-thirds of residents were female head-of-households, 95 percent had "never managed nor owned a business," 70 percent were unemployed, 70 percent had not graduated from high school, 93 percent were renters, and more than half "stated they would move out of the area if they could" (Urban League of Greater Miami 1978). Overtown had become Miami’s poorest neighborhood, and conditions in other African American neighborhoods were not much better.

Mounting racial tensions exploded in the 1980s. In April of 1980, Fidel Castro opened the port of Mariel to anyone who wished to leave Cuba. Under the Carter administration, Cuban immigrants were immediately granted refugee status upon arriving to the United States. Between April and October, some 125,000 Cubans left their homeland on boats headed to Florida. Most of the Mariel refugees had blue collar skills, as opposed to the professional class of Cubans that emigrated two decades prior, but quickly integrated within Miami's labor force by drawing upon those networks established by the first wave of immigrants (Stepick 1992). This experience differed dramatically from the 60,000 to 80,000 Haitians who immigrated to Miami between 1977 and 1981. Discourses about Haitian refugees as "disease-ridden," "uneducated," and "unskilled" spread rampantly throughout Miami, causing hysteria and precipitating 
efforts among south Florida's political elite to pressure federal authorities to restrict the flow of Haitians into Miami (Ibid., 60). Blacks in Miami witnessed the racial disparity in the treatment of predominantly white Cuban immigrants versus predominantly Black Haitian immigrants, which reinforced notions that race and citizenship in the US were inextricably linked.

On May 18, 1980, a white Tampa jury acquitted four white Miami-Dade County police officers in the killing of Arthur McDuffie, an insurance man who died after being brutally beaten following a high-speed car chase. Just a few hours after the verdict was released, thousands of people gathered in protest outside downtown Miami's Metro Justice Building. In the streets of Liberty City, bottles and rocks were thrown at passing cars. Before nightfall, a full-on riot had exploded across the City of Miami and spilled into parts of Dade County. The most intense rioting took place in sections of Liberty City, Allapattah, Brownsville, Overtown, and the Black sections of Coconut Grove, neighborhoods where de facto racial segregation still persisted. Over three days, eighteen lives were claimed, more than 300 people were treated for injuries, 600 arrests were made, and 240 businesses were looted or set on fire (see, for instance, Figure 4.4). The overall property damage from the unrest was estimated at $\$ 100$ million (Porter and Dunn 1984).

Historically, non-Black businesses have been the primary targets of inner city rioting, while leaving Black-owned businesses spared. The McDuffie riot, however, showed only some discrimination. While only one of the 102 stores that were completely burned out was Black-owned (Ibid.), dozens of Black-owned stores were damaged by 
surrounding fires, vandalized, and looted, forcing many out of business. A Miami Herald story reads:

The heart of Overtown has been destroyed. Two blocks of businesses were looted and set afire. The fires were terrific, spreading down both sides of NW Second Street [sic, "Avenue"], leaving just smoldering buildings on Monday where shops and restaurants and nightclubs had stood for 20, 30 and 40 years. [...] The two fires on the western side of Second Street [sic] spread and soon had burned Libby's Grocery Store, a black-owned business. A black-owned fruit stand and a black-owned pool hall were burned in between. (Grimm 1980, 19A)

Etta Thomas recalls her husband standing outside their store, wielding a pistol to prevent looting and damage. ${ }^{48}$ In addition to damaging businesses, the fires also "ruined the brand-new office of the Overtown Redevelopment Project" (Grimm and Bearak 1980, 2B), which had opened two months prior as part of a $\$ 50$ million plan to encourage private investment in the area.

In the aftermath of the civil disturbances, the Jimmy Carter White House assembled a task force to begin riot relief efforts in the Greater Miami area. By late June, Miami's city and county governments, civic groups, and private business sector began receiving what would amount to $\$ 70$ million in federal funds from various state agencies, with nearly \$27 million allocated for businesses and economic development. Of the \$17 million SBA loans provided to businesses between October 1980 and October 1981, nearly ninety percent went to whites or Latinos, "and fewer than half of these people ended up reopening their establishments in the riot areas" (Ibid., 169). In September 1980, the US Department of Commerce's Economic Development Administration (EDA)

\footnotetext{
${ }^{48}$ Etta Thomas, interviewed by author, 29 May 2015, Overtown grocery, Miami, FL.
} 
allocated $\$ 9.8$ million for neighborhood revitalization projects, a business loan program, a job training initiative, and a regional assessment for economic recovery.

Prior to the McDuffie incident, the City of Miami's Planning Department and the Overtown Economic Development Corporation (OEDC) had laid out plans for building a shopping center along Overtown's historic business corridor on Third Avenue, which they hoped would spur major commercial activity and employment for local residents. In light of the rioting, the EDA reviewed the City of Miami plans and allocated $\$ 1.6$ million towards the project. Over the next fifteen years, the shopping center provided a steady source of news for the Miami Herald, itself a symbol of the (im)possibility of revitalization in Overtown and Black Miami more generally.

According to the plans, the shopping center was to be anchored by a full-service supermarket, a first for the neighborhood. Attracting one to physically and economically distressed Overtown, however, would prove difficult. The Miami Planning Department advertised in regional and national magazines and a local newspaper, but to no avail. In June 1982 the Herald ran an article with the headline, "WANTED: SUPERMARKET FOR SHOPPING CENTER IN OVERTOWN NEIGHBORHOOD” (Bivins 1982). The article featured brief interviews with local residents about their experiences accessing food. Resident Verleane Brewer mentioned paying six dollars for transportation to the supermarket and back, a cost that actually ended up saving her in the long run, because corner store "prices are too high for the neighborhood." In 1980s Overtown, where the average household income amounted to just $\$ 9,000$, access to affordable food was high on the list of basic needs (US Census Bureau 1980). Athalie Range, a former Black city commissioner and one of the leading proponents of urban renewal during the 1960s, 
ironically stated to the Herald: "Certainly a shopping center of any kind would be a very fine thing, in view of the fact there is nothing much of any commercial area in Overtown" (Miami Herald Staff 1982). With neither interest from a single grocery chain nor any committed tenants, the shopping center broke ground that October.

Two months later Luis Alvarez, a Latino Miami police officer, shot and killed twenty-year-old Overtown resident, Nevell Johnson, inside a videogame parlor across the street from the shopping center construction site. Outraged, the crowd of forty inside the gaming room took to the streets, inciting what became another three-day episode of arson, looting, and violence (Ferguson 1983a). The shopping center construction trailers were the first targets of destruction before rioters moved to destroy nearby cars and other buildings. Business owners sat in their stores wielding guns to ward off offenders, though some arrived too late. One affected Palestinian-owned grocery had $\$ 50,000$ in merchandise and equipment stolen (Starita 1983). Joseph Cooper rushed to his grocery with his gun drawn and watched in amazement as looters emptied the store. Cooper lost $\$ 25,000$ in inventory as well as his cash registers, a deli slicer, a meat grinder, and a stove. Surprised that his business, a Black-owned one, had been targeted, Cooper told the Herald, "I worked for the Chinamen and then the Jews when they had the grocery stores. Then 15 years ago, I decided to open my own place. Everybody knows me" (Grimm 1983). Overtown resident and customer to the store, W. G. McElroy uttered, "This is stupid. Now I got to walk a mile just to get me a loaf of bread" (Ibid.). Though far less destructive than the 1980 riot, ten Overtown businesses were damaged, including three groceries and markets (Faber 1982). 
Following the civil disturbance, a prospective tenant of the shopping center decided to back out. In March 1983 Joe Wilson, executive director of the OEDC, told a Herald journalist, "None of the major chains wants to locate in the inner city and, so far, no independent food retailer feels it can make a large enough profit to justify operating away from its home base" (Ferguson 1983b). A year later, the acquittal of Alvarez by an all-white jury sparked the third civil disturbance in five years. Looters cleared the shelves of at least a dozen stores, including the Economeat and Fish Market located three blocks from the gaming parlor (see Figure 4.5).

During this time, Miami's inner city was not just rocked by the ripple effects of local instances of police brutality, but also by broader structural shifts in governance and economic and social policy. Championing ideologies of free markets, deregulation, and individualism, President Ronald Reagan implemented measures that increased economic liberalization and gradually dismantled the welfare state, ushering in a hegemonic neoliberal project that would become global in reach (Peters 2001). In the early 1980s, the Reagan Administration suspended construction and rehabilitation of public housing. They made deep cuts to social safety net programs, reducing budgets for school lunch and food stamp programs and guaranteed payments for the poor. Doubling down on the War on Drugs introduced by the Nixon Administration, Reagan instituted mandatory minimum sentence policies for drug offenses. Unsurprisingly, the effects in low-income communities and communities of color were devastating. Thousands of sick, elderly, and poor people slipped into homelessness. The heightened - and disproportionate incarceration of Blacks ripped at families and communities already struggling with the dejection of rampant Black male unemployment (Alexander 2012; Pettit and Western 


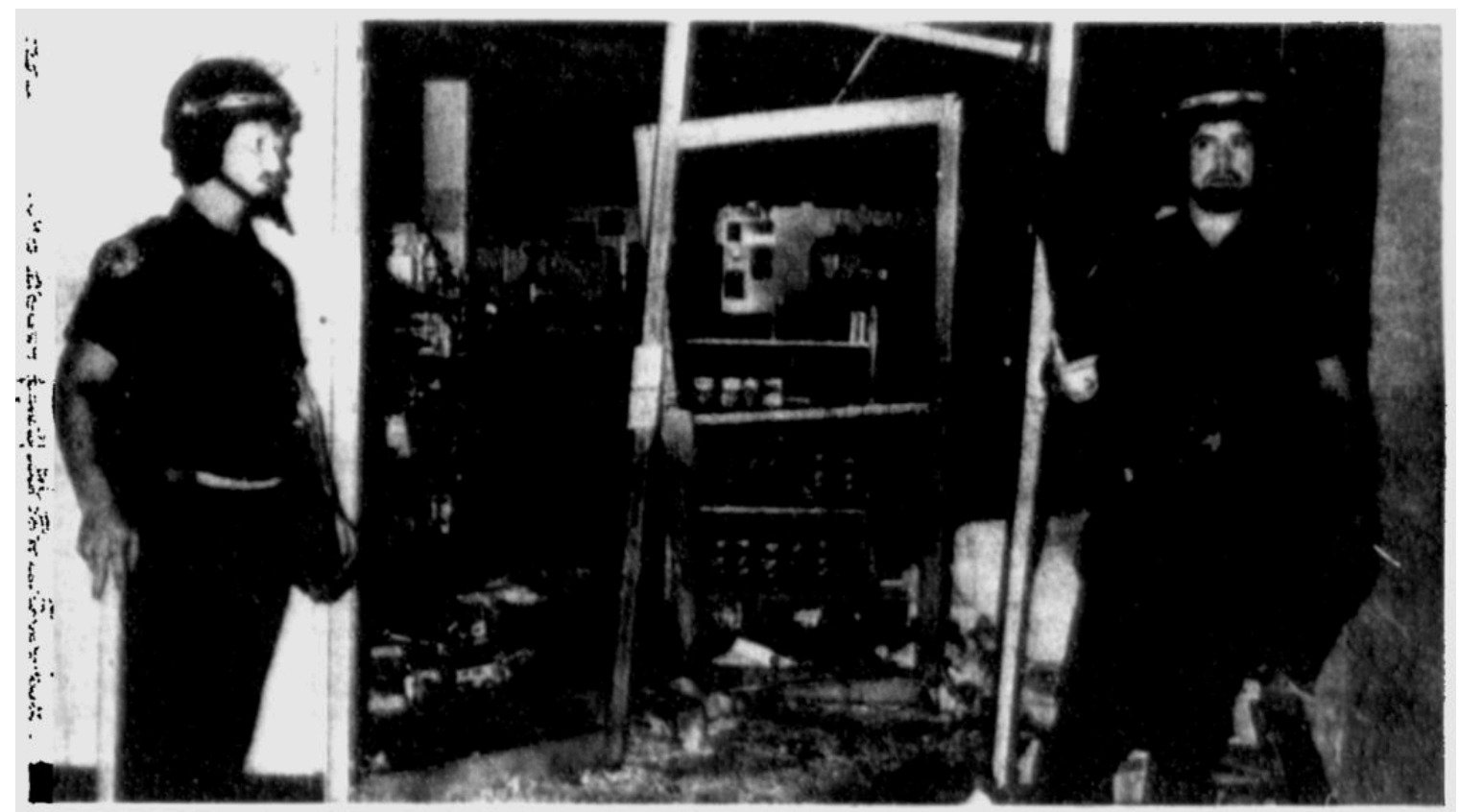

Figure 4.4: Police stand in front of a looted grocery in Overtown following a 1984 civil disturbance. Reprinted from Ocala Star-Banner, March 17, 1984.

2004). Inner city businesses served increasingly impoverished clienteles. Conditions in distressed Overtown were often reduced to bare life. A 1983 front page article of the Miami Herald describes "a 40-year-old mother cook[ing] an early dinner of lima beans for her nine children. Her stove is a barbecue outside her three-bedroom frame house, tilting, peeling and crawling with roaches and termites" (Freedberg and Ferguson 1983).

For Overtown residents, revitalization seemed a distant, if impossible, reality. Unemployment was a majority condition, and Blacks could barely take ownership in their neighborhood economy. In 1984, a report submitted by the Overtown Blue Ribbon Committee (1984), a group appointed by the Miami City Commission, identified "a crucial need for Black business development in Overtown." The report underscored various structural barriers including 
[d]iscriminatory policies and practices ... to secure credit and adequate venture and operating capital, and ... obtain adequate insurance protection at a reasonable cost.

Standard loan criteria prevent Blacks from acquiring capital needed for business development and expansion. Loan qualifications, such as collateral, equity in business, and a track record, are policies that exclude Blacks from real economic opportunity. Further, there is only one, newly established, Black-owned financial institution, which compounds the already existing problem of capital formation. (Overtown Blue Ribbon Committee 1984, underlining in original)

Indeed, Black business in Miami was at an all-time low. At the time of this report, only 1.6 percent of Overtown residents were entrepreneurs, and in Miami-Dade just " 1 per cent of the county's business establishments [were] Black-owned, and 82 per cent of those [were] one-man operations" (Fesperman 1982; Overtown Employment Survey 1983, cited in Overtown Blue Ribbon Committee 1984).

Things appeared hopeful, however, when in November 1984 three Black merchants reached an agreement with the OEDC to open Super Save, a 15,000 square foot supermarket, in the Overtown shopping center. ${ }^{49}$ Putting up their own homes and those of relatives as collateral, the three co-owners were able to acquire $\$ 385,000$ in grants and loans respectively from the county and the Miami Capital Development Inc., a lending institution that received EDA funds following the McDuffie riot, to purchase needed equipment and finance the build out of the store. In the first weeks of its opening, Super Save attracted hundreds of customers a day. The store staffed forty people, many whom were formerly unemployed, as checkout clerks, baggers, and stockers. After decades of public neglect, unemployment, police brutality, and periodic rioting clouding

\footnotetext{
${ }^{49}$ One of the owners, Charlie Lowe, had previously owned a Grand Union grocery store that fell victim to looters during the 1980 riot, amounting to $\$ 70,000$ in lost merchandise (Cotterell 1980).
} 
hopes among Overtowners, the opening of Super Save seemed like a new day of Black enterprise, employment, and prosperity had arrived.

But Super Save would not last long. Just one month into the store's operation, the city began a massive street renovation project on Third Avenue, the only road running along the Overtown shopping center. Barricades were placed in front of the shopping center's entrance and needed constant removal to let customers in. Much of the center also appeared vacant with only the grocery, a coin laundry, and a small county family center occupying its ten units. Business at Super Save soon slowed to crawl. The store reported weekly sales near $\$ 50,000$ prior to the street repairs and less than half of that afterwards. "We were doing tremendous business until the road became impassable. We were hurting for ten weeks. We haven't recovered yet," Thomas Jones Jr. told a Herald journalist (Thomas 1985a).

With such low sales, the owners were unable to pay their monthly rent of $\$ 4,500$ to the city, a debt totaling nearly $\$ 30,000$ after six months. The owners reported anticipating an extra $\$ 100,000$ from Miami Capital Development that was negotiated during the deal but never arrived. Unable to reach a financial agreement with the OEDC to pay back the rent, Jones and his business partners were evicted and forced to shut down the store (Thomas 1985b). The closing of Super Save quickly scared off other prospective tenants, including Church's Fried Chicken and a Miami Savings and Loan branch. Given the OEDC's failure to facilitate an economically viable use of the shopping center, the Miami City Commission voted in favor of terminating their lease in February 1986. For the next four years, the center lay nearly dormant with its anchor unit uninhabited. 
In January 1989, Colombian police officer, William Lozano, shot an unarmed Black motorcyclist named Clement Lloyd during a chase, killing him and his passenger, Allan Blanchard, after the motorcycle crashed. In less than hour, residents of Overtown erupted, throwing rocks, burning buildings and cars, and looting businesses. Rioters forcibly removed a jitney cab driver from his car and drove it into the Georgia Meat grocery, making this the second time the store had been targeted during a civic disturbance. The Latino storeowner, Sixto Mendez, later told the Miami City Commission his store incurred $\$ 86,000$ in property damage and lost stock (Lassiter and Billington 1989). Three years later, Mendez shut the store down. A couple buildings over from Georgia Meat, the United Family grocery store was badly burned and ransacked. A front page article of the Miami Herald described the storeowner, who allowed customers to purchase goods on credit, as well-liked by residents. "This is a shame. I don't like to see good people like this suffer," Odessa Miller told the Herald. "They could have taken what they wanted and left the man his store" (Roman and Ramos 1989).

Management over the Overtown Shopping Center changes hands in August 1988 when Howard Gary, formerly the nation's highest-paid and Miami's first and only Black city manager, negotiated with the city to take over the lease under his private firm, Overtown Ventures. Despite being voted out of his position in 1984 by the three Latinos on Miami's five-seat commission on grounds of "personal style," Gary had built a strong reputation for himself as a savvy businessman, having turned to the private sector to start his own successful bond firm, which at the time was Dade County's only Black-owned underwriting firm. Whatever clouds may have surrounded Gary's past, they did not interfere with his ability to obtain a favorable deal: two years rent free and $\$ 12,000$ a year 
thereafter; the sale of $\$ 150,000$ worth of coolers, produce cases and shopping carts for $\$ 1$; deferred costs for extermination, painting, and freezer maintenance; and $\$ 100,000$ in store renovations (Goldfarb 1990).

Never intending to open a store himself, in 1990 Gary transferred the deal over to Yahweh Ben Yahweh, ex-member of the Nation of Islam, self-proclaimed son of God, and founder of the Black religious sect, the Nation of Yahweh. By this time, Ben Yahweh had been running the Nation of Yahweh's headquarters, Temple of Love, for more than eight years in nearby Liberty City, the neighborhood where Gary grew up. During the 1980s, Yahweh renovated derelict properties in Liberty City and other Black communities in Dade County, while gradually amassing a real estate empire worth over \$100 million, which included satellite temples, apartment buildings, motels, and a recording studio. In the heated context of periodic race riots, Yahweh's leadership earned him many followers as well as considerable influence among Miami’s political elite. In 1987, he was presented with the Urban League of Greater Miami's highest honor, the Whitney M. Young Humanitarian Award, and three years later received his own official holiday, Yahweh Ben Yahwen Day, by then Miami mayor Xavier Suarez. Ben Yahweh, however, was hardly a saint. By the time the subletting contract for the supermarket was made, Yahweh and the Temple of Love were indicted on federal allegations of murder, arson, extortion, and racketeering conspiracy and had a pending court order to pay nearly a million dollars in civil fines for conducting a "terrorist occupation strategy" in one of their apartments.

Despite the ongoing investigation, in as little as two months Yahweh and group of his followers cleaned the Overtown Shopping Plaza, purchased and repaired equipment, 


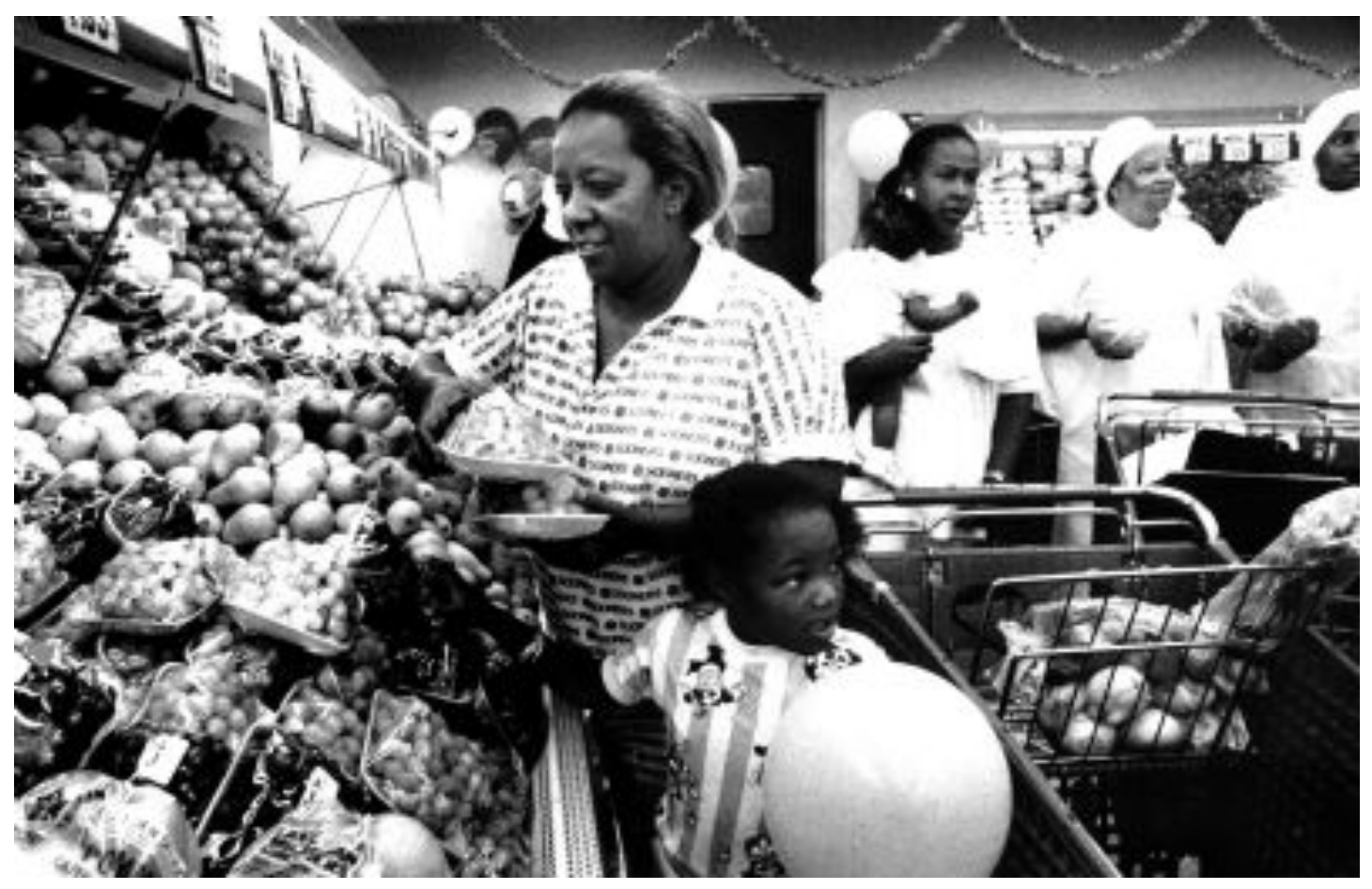

Figure 4.5: A mother and daughter shopping during the grand opening of First Rate Foods. Ben Yahweh followers in the background. Reprinted from the Miami Herald.

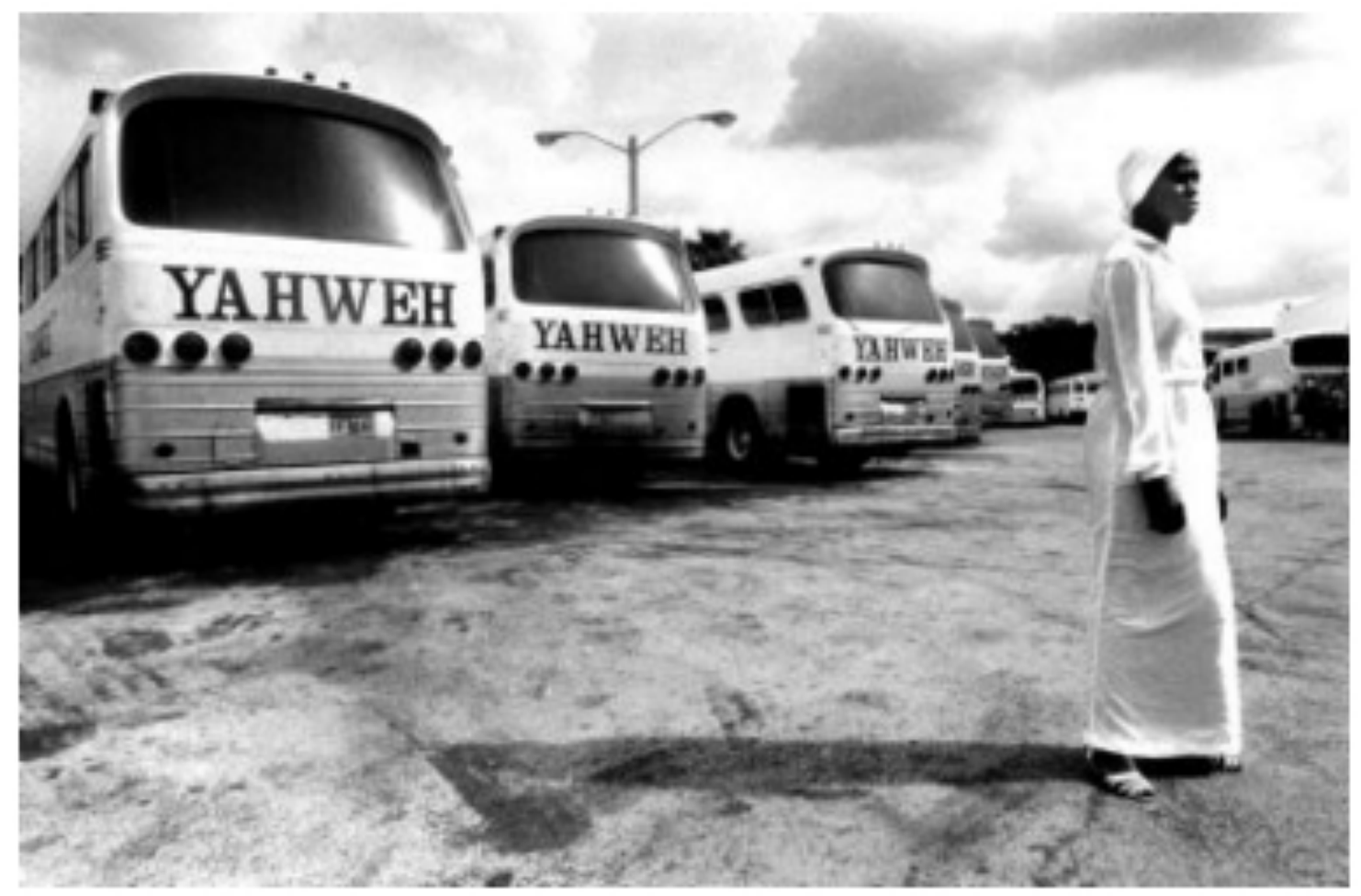

Figure 4.6: The Yahweh bus fleet. Reprinted from the Miami Herald. 


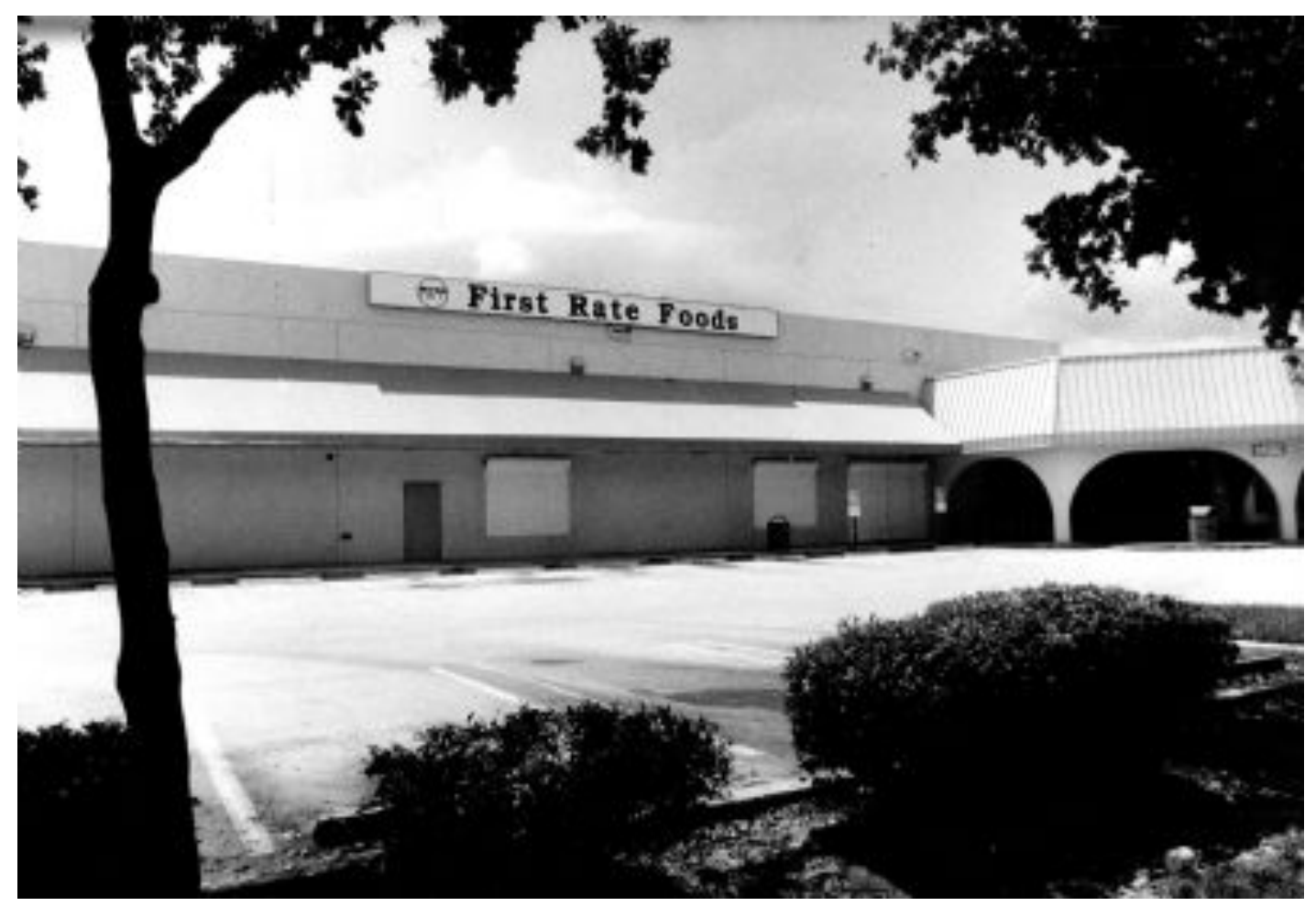

Figure 4.7: First Rate Foods in the Overtown Shopping Plaza after closing down. Reprinted from the Miami Herald.

and stocked shelves with groceries to prepare for the grand opening of First Rate Foods in the spring of 1990 (see Figure 4.6). During the grand opening, a brass band played while civic leaders and a hundred followers dressed in white robes moved through the crowd to shake the self-proclaimed messiah's hand. Mayor Suarez praised Yahweh “for improving the lives of our people through economic development, through discipline, and through hard work." One follower added: "Out of a city of despair, Yahweh is causing a repair. And to a people that have sat in darkness, now Yahweh is raising a great light of hope" (quoted in Freedberg 1996, 249).

First Rate Foods, however, did not attract the amount of business Yahweh had hoped it would. Yahweh's influence had heretofore yet to cross into Overtown in any 
meaningful way. Many residents were unfamiliar with him, wary of his messianic claims, or afraid of his increasingly notorious image. In an effort to encourage business, Yahweh offered residents a shuttle service and urged his public relations person to promote the store to residents (see Figure 4.7). According to Sydney Freedberg, a Miami Herald journalist who covered Yahweh's story in depth, one woman stated: "I ain't getting on the bus with somebody who thinks he's Jesus!" (Ibid., 251).

Then, some seven months after the opening of the supermarket, the FBI led a raid on Ben Yahweh and sixteen members of the Nation of Yahweh, arresting them and forcing them to appear before a grand jury. First Rate Foods remained open until June of the following year when it closed its doors without notice (see Figure 4.8). The federal trial against Yahweh was reported to have exhausted much of his resources and energy. In 1992, Yahweh and six of his disciples were convicted of murder conspiracy "in connection with the plotting of 14 separate murders, two attempted murders and the terrorist firebombing of an entire block in Delray Beach" (Clary 1992). In a 1994 publication, the Temple of Love linked the persecution of Ben Yahweh to generations of state assaults on Black movements and progress:

By forcing First Rate Foods to close, the U.S. Government is sending a clear message to Blacks, discouraging them from "doing for self." At the same time, by reversing Affirmative Action, vetoing the Civil Rights Bill, and turning back the civil rights calendar with ultra-conservative Supreme Court rulings, Blacks are being discouraged from asking the Government for assistance. If the U.S. Government does not want to assist Blacks and does not want Blacks to help themselves, then what do they want Blacks to do? The U.S. Government is clearly illustrating to sixty million Blacks of America that they have no future in this country. How many times in this century have we seen a Black leader actually unite Black people towards success, only to see the Government attack the leader and his movement relentlessly? (The People for Truth 1994, 123). 
After the closing of First Rate Foods, Gary offered the lease to Ricardo Corona, a former Cuban bank executive whom Gary had known for more than a decade. During his time as City Manager, Gary sat on the board of directors of a bank run by Ricardo’s father and brother and where Ricardo himself served as the Vice President ${ }^{50}$ Gary even received loans by the bank to purchase rental properties in Overtown. In the mid-1980s, Mr. Corona left the banking business and opened a handful of supermarkets across Dade County. Having declined previous invitations from Gary to consider locating to the Overtown shopping center, he decided to take a second look after the closing of the Yahweh grocery. In an interview with me, he described the matters he took into account as he considered placing his business in Overtown:

I looked at Overtown. Overtown was an area that was not serviced by any major store. It was a densely populated area ... but there was no stores, ... you know, there was all corner stores, small stores, that charged significantly more than supermarket prices for their goods, but there was no full-service supermarket within the area, even as densely populated as it was ... There was a couple of stores outside. There was an old WinnDixie, it was a small Winn Dixie, outside of the area nearby and there was another independently owned store. I drove through the neighborhood, and I didn't see anybody starving, you know, so I mean ... I think that they're eating. It wasn't a very scientific research, you know, I think people are eating there, so if they're eating they have to be buying their groceries somewhere. At that time, being a Latino Cuban, you know I was born in Cuba, and there was in Overtown, there was tension between the African Americans ... There was tension in the neighborhood regarding the police, similar to what there is now that we're seeing with Ferguson and the other in Baltimore. ${ }^{51}$

\footnotetext{
${ }^{50}$ As one of Miami's leading Cuban bank executives, Ricardo's father also played a prominent role in granting loans to Cuban exiles.

${ }^{51}$ Ricardo Corona, interviewed by author, 22 May 2015, Corona Law Firm, Miami, FL.
} 
At this time, Mr. Corona was struggling to compete against the larger regional and national grocery chains in the suburban neighborhoods where his markets were located:

It was difficult to go head to head against Costco, Winn Dixie, and Publix. I had done it, you know, but it's a struggle. And very difficult to win, really, against them. You can survive, but I don't know that you can win. And I says, well, here I don't have them, you know. What are the issues that can come up? You know, they happen really more on a personal level rather than competition-wise, and I think I can deal with and overcome, you know, those issues with somebody there rather than having to compete against the Publix. ${ }^{52}$

In other words, Mr. Corona felt if he could overcome the day-to-day interpersonal issues and racial and ethnic tensions in the area, he could fill an open niche offering a convenient supermarket experience to local residents.

Corona then approached the Overtown Advisory Board, a board created by the city in 1980 to oversee and facilitate developments in the community, to present a $\$ 200,000$ investment and gauge the board's receptivity to having a Cuban-owned grocery anchoring the shopping center. In his proposal, he promised to employ local residents and offer the same prices on goods he offered in other parts of the city. The board agreed to his proposal, and in a matter of weeks Crown Supermarket had opened. At this time, the supermarket was the only retail outlet in the shopping center, with only a mini-police station, the Overtown Advisory Board office, and a family outreach center occupying three of the remaining units. The owner also purchased Overtown Ventures from Gary and became the new official lessees of the shopping center.

\footnotetext{
${ }^{52}$ Ricardo Corona, interviewed by author, 22 May 2015, Corona Law Firm, Miami, FL.
} 
Business at Crown was slow at first, bringing in just enough customers for $\mathrm{Mr}$. Corona to break even. Over time, however, he was able to boost sales by responding to the needs of his customers. He described how working with the Overtown community was in one sense easier than in other areas, as the people were vocal about their preferences for specific goods and products. He mentioned how customers were not nearly as concerned with purchasing popular brands as they were with getting a good value. Whereas more affluent consumers tend to shop for reputable brands, in Overtown there was a niche market for "private labels," which could be sold to consumers cheaper than major brands and still net a wider profit margin. Corona also noticed many of his customers arrived to his store on foot and purchased just a few goods so they wouldn't have to carry heavy bags on their walk back home. He soon began to offer free car rides to nearby residents who spent at least fifty dollars.

In 1993 Mr. Corona's commitment to Overtown was put to test. Prior to the opening of the supermarket, the conviction of officer Lozano for manslaughter was appealed and overturned on grounds that the jury's decision was influenced by fears of rioting (Alvarez et al. 1993). In May 1993, on the day before the verdict was issued in his second trial, the National Guard arrived. The next day, local police officers surrounded Overtown and told business owners to lock up their stores and go home. Lozano's defense attorney, Roy Black, would serve him well, portraying Overtown as "a den of criminality and drug use" in "the murder capital of the United States and the most violent city in America" and convincing an Orlando jury to acquit the police officer of all charges (Rohter 1993). 
Residents immediately took to the streets again. Before long, Corona received a call from an Overtown resident claiming that people were breaking into his store. He immediately called the police, who arrived to find a large hole rammed through it, several cash registers missing, and display cases knocked over. After hearing from the police that the looters had been apprehended, the grocer received a second call that the police had vacated the property, leaving the large gaping hole to his store unprotected. He described to me the lengths he went to guard his business:

As I'm coming into the street, pulling up to the store, ... they had ... raided and they trashed the police station that was in the shopping center. Then they took the dumpsters back way around the block, brought 'em to the front and had put tires in it and had set it on fire. So as I'm driving in, there's a dumpster up front with flames of twenty or thirty feet into the air, right up front of the store, with black smoke, and there was a crowd of people. I don't know how many people, 50, 100, I don't know. And in front of the store there ... was a guy from the neighborhood ... And he's saying, 'Yeah, you can't go into the store.' He was stopping them. And the crowd was cussing him out, they says, you know, 'Why you defending a white cracker?' and, you know, things like that.

So I pull in there, and they're about to, I can feel it, they're about to blow up on this guy. And I drive up behind him in the van, and I get out, and I decided to address the crowd. And I look at them. And the thing I think is there's a difference between being an anonymous part of a crowd and being an individual. These people I've dealt with individually and my thing was, when they ran out of money or things like that and they needed Pampers for their babies, I would give them Pampers for their babies.... I would just give it to them. So then I started looking at them. I come to the crowd, I said, 'Look. I'm here. I'm gonna go inside. I'm gonna stay here tonight. I really don't want any issues with you all. But at the same time, I gotta protect my property ... If somebody goes in there, we're gonna have issues.' And I went in there, and I went in through the hole and I stayed the night... and I could hear all sorts of noises and things going on out there. ${ }^{53}$

Despite the damage he incurred from this incident, Mr. Corona reassured me: "I never had any, that was the only, I never had an issue really. I mean, that was the only

\footnotetext{
${ }^{53}$ Ricardo Corona, interviewed by author, 22 May 2015, Corona Law Firm, Miami, FL.
} 
thing, and that was a few kids just taking advantage of the things, and the people respected my store." He described how after his store had been robbed, "a few women were helping me cleaning up wherever people had knocked down some things, broken some bottles." A reporter from National Public Radio was also in his store at this time, provoking him to rehearse the dominant narrative of troubled race relations stoked by popular media: "He says, 'Hey, how you feel about the Black people now that they trashed your store?' He was fucking with me. And I said, 'Well, you know, you see these ladies here? They're from the community, too. They don't work here. Man, they're helping me for nothing. That's what the community is. So no, I feel that they have reinforced my trust that I have here." ${ }^{54}$ Corona's experience resonates with Lee's (2002) finding in which immigrant business owners noted few serious conflicts with the African American residents they served.

In the following years, Corona continued to operate a profitable business in Overtown. Yet this was not solely due to sales alone. According to a 1994 Herald story, the owner had not paid a single month's rent since moving in three years prior and owed $\$ 95,000$ in back payments and utility bills (Cavanaugh 1994). Corona claimed the city had not held up its end of the deal in maintaining his store and the property, which cost him more than $\$ 70,000$ in repairs. To be sure, the center was repeatedly described in newspaper articles as neglected by the city, often having burnt out lights, broken air conditioning and plumbing, peeling or vandalized paint and litter and debris scattered about the premises. Meanwhile, the storeowner had not purchased liability insurance, a requirement of his lease, and had sectioned off parts of the store for his brother's export

\footnotetext{
${ }^{54}$ Ricardo Corona, interviewed by author, 22 May 2015, Corona Law Firm, Miami, FL.
} 
business and his wife's wholesale flower business. In 1996, after an ensuing legal struggle, an agreement was reached where the owner would pay $\$ 18,000$ a year in rent to the city, an annual rate $\$ 36,000$ less than the first supermarket tenants were required to pay more than ten years earlier.

The store would continue to serve the community into the 2000s. During this time, Corona was also studying to become a lawyer, and eventually even opened a law practice next door to the Crown market. With his law practice gradually taking up more and more of his time and attention away from the store, Corona later decided to transition out of the supermarket business. In 2004 , he sold his lease back to the city for $\$ 200,000$ and moved his firm to Coral Gables. For the next decade, the shopping plaza remained virtually void of commercial activity.

\section{Grassroots for Groceries}

Born in Savannah, Georgia, Leroy Jones moved to Overtown at age nine in 1971, just one year after the I-95 expressway was completed. At age ten, he began working after school at a neighborhood grocery called Hence \& Sons. He remembers on one occasion accompanying Mr. Hence to the wholesale distribution center and noticing white customers paying with promissory notes while Black customers paid with cash. Mr. Hence explained to him the different treatment whites received in business. Pained by the injustice so casually taking place in plain sight, Leroy Jones later made it his mission to assist Black businesses despite the many racial barriers to success they continue face.

In addition to experiencing everyday forms of discrimination, Black entrepreneurs have historically had difficulty overcoming institutional barriers to accessing loans and 
credit. Consider that in an August 1964 meeting, Eugene P. Foley, an administrator of the Small Business Administration (SBA) stated, "I am ashamed to admit that my agency had made seven loans to Negroes in ten years" (cited in Lee 2002, 30). Despite programmatic changes after the passing of the 1964 Civil Rights Act permitting the SBA and the Department of Commerce to allocate federal assistance to racial and ethnic minorities, what Blacks received fell far short of "what was secured by white American business in subsidies, grants, loans, loan guarantees, procurements, and tax breaks" (Walker 1998, 265). In the year spanning July 1967 to July 1968, for instance, whites received more than two-thirds of all SBA loans and about ninety-four percent of the total loan amounts, while Blacks received six percent of loans and three percent of total loan amounts.

A wealth of research also shows that Black businesses have since continued to face discrimination in access to loans and credit, "even after controlling for differences in credit worthiness and other factors" (Fairlie and Robb 2008, 113; see also Blanchard, Yinger, and Zhao 2008; Blanchflower, Levine, and Zimmerman 2003; Cavalluzzo, 2002; Cavalluzzo and Wolken 2005; Coleman 2002, 2005; Fairlie and Robb 2007). Compared to whites, Black business owners are more frequently denied credit (Cavalluzzo et al. 2002), report "lack of access to personal loans/credit" as an explanation for business closure (Fairlie and Robb 2008), and pay higher interest rates on loans received (Blanchflower et al. 2003). As Fairlie and Robb (2008), among others, describe, the single most important determinant of business success is the amount of initial capital invested, and Blacks as a group have the least to invest (Altonji and Doraszelski 2005; Blau and Graham 1990; Oliver and Shapiro 2006). Most wealth in the US is accumulated through returns on investments in property and business. But as the history of Overtown 
illuminates, state policies have historically structured opportunities for home and business ownership along racial lines (Oliver and Shapiro 2006).

Additionally, immigrant entrepreneurs can often draw resources from family, friends, and co-ethnics - as gifts, loans, or through rotating-credit associations - whereas African Americans generally have little personal savings and monies available from personal networks (Bonacich and Modell 1980; Butler 2012; Lee 2002; Portes and Jensen 1989; Waldinger, Aldrich, and Ward 1990). For example, one Middle Eastern grocer in the area told me how he was introduced to the grocery business in Overtown by working in a friend's store. Later, he would open his own store and employ one of his own friends, who also eventually opened his own store. "He used to work for me. [...] I used to take care of him. When he came from his country, I bought him car. You know, car like $\$ 1500, \$ 2000$ used car. Then he go with it and come to work and I let him responsible for the store. [...] In two years, two and a half years, third year he left." ${ }^{, 55}$ Blacks therefore, as opposed to other minorities, enter the game of business with significantly fewer resources, limiting their options for growth and success.

Having experienced these hurdles himself, Leroy Jones began community organizing in Liberty City in the mid-1990s to spur Black business development. An astute businessman in his own right, Jones owned multiple properties and formed several businesses, including a landscaping company that survived through one of Jones's stints in prison. After serving his last of three prison sentences, Jones returned to Liberty City and helped with his family's grocery store. Within six months Jones had made several improvements, such as adding a gaming parlor and increasing the store's square footage

\footnotetext{
${ }^{55}$ Johnny, interviewed by author, 4 August 2015, Overtown grocery, Miami, FL.
} 
four-fold. His work quickly gained the attention of other Black business owners in the area. In a 2012 interview, Jones stated:

All the other little stores in the neighborhood would ask my mother and sister when they would see them at the food warehouse, "What did you do to grow your store and what did you to do to make the improvements to your store?' My sister would tell them that 'My brother came in and help us in the store. He showed us how to manage the store.' So, one day, these ladies came to the store and said to my mom and sister that they wanted to meet me. I was not there that day. So, on Sunday, they returned to the store and met with me. They convinced me to start having meetings to help them with their businesses. (Sports Elite 2012)

After hosting several business meetings in the grocery's gaming parlor, Jones decided in 1995 to found the Neighbors and Neighbors Association (NANA), an alliance initially comprised of some 150 businesses. The first project NANA undertook was a buy-out program for struggling Black-owned groceries. Twice a month they coordinated buy-outs, encouraging NANA affiliates and the Black community at-large to purchase at least $\$ 25$ at a particular inner city store. The purchased food was then donated to public housing units in the community. The program was successful in the short term, in that it injected a few thousand dollars of needed capital into the Black business community. It also received notable attention from local government, which NANA used to successfully apply for Miami-Dade County Community Development Block Grant funding in 1996 and 1997. In the next year, Leroy Jones received the Merit Award, Miami-Dade's highest civilian honor, for his work with NANA.

Yet the buy-outs alone could not counteract the many challenges of sustaining a small grocery in the inner city. By the late 1990s, Overtown's Black-owned groceries were barely hanging on. For the Thomases, the various license and certificate fees required to operate had risen, totaling $\$ 1100$ per year. After losing the easy-to-hawk 
copper wiring on their refrigerator case to theft, the grocery's inventory had reduced to a collection of beer cans floating in two vats, a few cartons of cigarettes, some bags of charcoal and two short aisles of canned and boxed goods, chips, cookies and other snack foods. A few blocks away, where the Thomases first met, a thirty-year-old grocery store needed "total renovation: the roof, the inside ceiling, the bathroom, the floor, the walls" (Nielsen 1999). The owner's brother also ran a grocery in the area, which too sorely needed repairs. Meanwhile, business competition in the neighborhood was steep. Several Middle Eastern grocers in the area offered better prices and stayed open twenty-four hours a day.

NANA soon began to provide Black businesses with a range of free services, such as conducting job trainings, assisting with technical matters, acquiring necessary permits and licenses, and applying for loans and grants for store renovations. In 1999, NANA assisted the Thomases and four other Black Overtown grocers with applications for $\$ 25,000$ community revitalization grants from Dade County’s Office of Community and Economic Development. However, of the program's fifty-two awardees, none were from Overtown, despite each of the grocery's desperate circumstances as a result of having suffered years - if not decades - of economic and social strife with the community. Unfazed, in the next two years, NANA helped secure nearly $\$ 1.3$ million in grants for Black-owned businesses across Miami, including hundreds of thousands of dollars for Overtown businesses. The Thomas grocery, for instance, received over $\$ 75,000$, mostly through the Metro-Miami Action Plan, an initiative developed in response to the civil unrest of the 1980s. 
The Thomases used the money to add a bakery to their store, hoping to increase

revenue during a time of dwindling grocery sales. During an interview held at her

grocery, Etta Thomas explained to me:

Back in the days when I first opened up, I used to have meat. Before I remodeled in 2000 , I used to have meat. ... This wall wasn't here, it was like shelves, like four lines [aisles] of shelves straight back. ... Business changed when they opened up a Publix on Biscayne. It changed when they opened up the Winn Dixie on Twelfth Street. Mom and pop stores don't have nothin' on the big stores, 'cause they have everything that mostly you would want, you can go in and get it, when the mom and pop store cannot afford that. Winn Dixie or Publix or Price Choice or whatever, they can get a big quantity of stuff and they can sell it for a lower price. And with me being a poor black woman I have to get one o' these, one o' these, one o' these, one o' these, one o' these, and one o' these. So I get charged more money to buy less stuff. ... They can run a special three cans of corn for a dollar. I can't run that special. ... So now people, most people, this is more like a convenience store that, 'Hey, if I run outta hot sauce, I come by and get a hot sauce. If I run outta ketchup, I'd come by and get a ketchup. Or if I want a cold soda, I come by and get a cold soda, then I'll get a potato chip. Something like that.... Most of the residents Overtown now, they have their cars. It's not walking traffic anymore. So if they got their cars, they go to where it's more convenient for them, than a mom and pop.... And I don't, you know, I don't knock it because I know times are tough, and a lot of 'em don't make a lotta money, [they] have a lotta children, so they have to do what they have to do. ${ }^{56}$

In addition to the bakery, the Thomases also looked into the idea of opening a

small restaurant in their store. By this time, the Thomases had been offering a daily

selection of prepared dishes and treats, including sweet potato pie, coconut cake, banana

pudding, seasoned pineapple slices and Muscadine grapes, conch salad, fried chicken, and roast turkey and rice. Mrs. Thomas drew culinary inspiration from her mother's Southern cooking ("It's like an inheritance. Growing up in my house, she [her mother] would do all the baking for holidays, you know.... She would make sure we had a

\footnotetext{
${ }^{56}$ Etta Thomas, interviewed by author, 17 August 2016, Overtown grocery, Miami, FL.
} 
dessert for Sunday dinner. Cakes, pies, peach cobblers, blackberry pie.”) and from the Afro-Caribbean foodways she became familiar with as a Miami transplant (I ate a couple conch fritters and in my head I thought of some of the things [ingredients] that they had in there, so I tried it, putting some of the things that I seen that was in there. Spices and stuff. Seasoning. I learned that here in Florida.”). ${ }^{57}$ The Thomases, however, were told by the city that the building next door was too close to where their smoke vent would need to be placed. When Mrs. Thomas asked, “'Could I have my vent [facing] up?' They told me if I carry it straight up my building, that it'd be on the expressway. The smoke would be goin' up on the expressway." 58 The highway ran directly behind the Thomas grocery. It once drove hundreds of Overtown businesses out of business and continued to stifle Black economic development.

NANA went on to becoming a highly successful non-profit, acquiring millions of dollars in annual grants to continue technical assistance for small businesses and support several economic development initiatives. In 2007, NANA's Micro-Enterprise Business Assistance Program awarded the Thomases $\$ 10,000$.

\section{Making the Food Desert}

Up to now, most of the academic work examining the production of food deserts focuses on the link between food retail and segregation (e.g. Hurtz 2013; Kwate 2008). What I hope to add to this research is how institutional and infrastructural racism in the postwar period not only reproduced segregation but also fostered greater capitalist

\footnotetext{
${ }^{57}$ Etta Thomas, interviewed by author, 17 August 2016, Overtown grocery, Miami, FL.

${ }^{58}$ Etta Thomas, interviewed by author, 17 August 2016, Overtown grocery, Miami, FL.
} 
penetration into Black communities while deteriorating existing forms of social and economic interdependency forged out of necessity during legal segregation. As we saw in the last chapter, Overtown's food businesses played a major role in producing a separate neighborhood economy. However, the deliberate destruction and stifling of Black business along with the coerced displacement of the Black middle class left Overtown both unattractive for major retailers and yet wide open for new immigrant entrepreneurs equipped with competitive advantages in access to resources.

Meanwhile, the converging of infrastructural entrapment with social, economic, and political marginalization produced Overtown as a kind of "carceral geography" (Moran 2015; Shabazz 2015), a racialized space of containment disproportionately subject to practices of surveillance and punishment. Unpunished acts of police brutality reified the persistence of anti-Black racism and violence beyond the civil rights era. When the police can enter one of Overtown's few safe community spaces (in this case, a gaming arcade), kill a young man, and get acquitted, this is state-sanctioned terrorism and urbicide, or what McKittrick (2011) defines as the eradication of a "black sense of place." Black communities responded by lashing out against the very environment that imprisoned them.

Although Black business owners were rarely spared during these riotous eruptions, it was the federal and municipal institutional response that, guided by a mounting neoliberal agenda, failed to address decades of racism and neglect and in turn exacerbated existing social inequalities in the distribution of resources and opportunities. Beginning in the 1980s, we see Miami beginning to emerge as an entrepreneurial city, implementing top-down efforts to lure retail as a strategy for revitalizing Overtown, a 
strategy that persists with even greater force today. As we saw, this effort further disenfranchised existing neighborhood grocers by creating opportunities only for those with considerable political connections and access to capital.

What I have also hoped to show is that even under such oppressive circumstances, Black entrepreneurs have creatively fought to maintain a footing in business and in the provision of food. These important efforts are repeatedly rendered invisible by discourses and cartographic mappings of food deserts, which focus primarily on the location of supermarkets while commonly vilifying smaller neighborhood stores, all while glossing over the long history of racism that have suppressed the growth of Black business. 


\section{V.... NOT BE SO QUICK TO PUT BUILDINGS IN THOSE SPACES: THE SPATIAL POLITICS OF THE ROOTS IN THE CITY GARDEN}

After the 1980s riots and nearly twenty years of government failure to address inner city poverty since the completion of the interstate highways, Overtown was visually marked by its vacant lots, littered streets, dilapidated buildings, and a handful of small, mostly struggling, businesses. In the late 1980s, Dr. Marvin Dunn, an African American psychology professor at Florida International University, began leading beautification projects throughout Overtown. Dunn was an active researcher of Black Miami (see, for example, Dunn 1997), and given the public divestment of Miami's Black communities, felt the impetus to better conditions for residents. On Saturdays, Dunn recruited his Community Psychology undergraduates to clean street ways and plant botanical garden rows along highway embankments. Teaming up with Overtown Neighborhood Partnerships, a program designed and directed by Miami-Dade Community College and Overtown residents, Dunn and his volunteers helped cover two lots abutting the I-95/I395 expressway system with some 8,000 plants.

During an interview at his home, Dunn told me that on one Saturday beautification outing a resident shouting from across the street, "Hey Doc, why don't you plant something we can eat?" 59 A 1995 focus group conducted by Overtown Neighborhood Partnerships with residents also revealed great interest for community gardens, which soon led to vegetable gardening projects at several neighborhood sites. "There are a lot of people in Overtown who have poor diets," stated one project consultant, a University of Miami public health professor. "This is going to provide them

\footnotetext{
${ }^{59}$ Dr. Marvin Dunn, interview by author, 29 April 2015, Dunn’s home, Miami, FL.
} 
with fresh produce, and help them economically" (Charles 1995, 1B). The project's plan involved church groups and community residents tending to raised garden beds and taking home or selling the produce. Local organizations including Fairchild Tropical Botanic Garden, the Florida chapter of the American Society of Landscape Architects, and the Miami Dade Soil \& Water District provided soil and pitcher pumps while City National Bank donated money for tools and other supplies. In addition to planting beds of turnips, collard greens, and tomatoes on available vacant lots, a garden was also created for students at Phillis Wheatley Elementary School just inside Overtown's northeastern edge.

Just before the turn of the century, Dunn found a new growing partner in Ignatius Murray. Having struggled throughout the 1980s to earn a livelihood farming in his homeland, Murray immigrated to Miami to work construction and other skilled trades and hoped to return to Jamaica after making enough money. In the late 1990s, he moved into a small Overtown apartment that overlooked one of the neighborhood's many vacant lots, this one a city-owned parcel filled with construction materials, old bottles, and other kinds of trash. After clearing the debris, Murray planted in its place hot peppers, okra, banana saplings, and sugar cane. Murray's guerilla gardening was quickly noticed and appreciated by residents. An Overtown landlord even invited Murray to green several of his properties. The gardens, which eventually spanned some two and a half acres, were a coveted space for many Overtown youth, upon whom Murray often tried to impart his agricultural knowledge. "The children here think potatoes grow in the store. They think okra grow in the store. They think beans grow in the store," Murray once told a local newspaper. "I want to show them the land that they got, and what the land can provide" 
(Eastman 2002). Recognizing Murray's expertise, in 2001 Dunn employed him as a fulltime consultant for Roots in the City. In 2015, I interviewed Murray in a vacant lot once gardened under the Roots in the City project. When asked how he got involved with the project, he told me: "I was doing this [gardening], and he call me and he see me doing it, you know? I was over on Fourth Avenue. I was doing a little crop, doing a little thing. So he wanted to make it bigger. So he have me with him. And he was getting the funding from the government." ${ }^{, 00}$

Over the course of nearly two decades, Roots in the City grew to become the most visible and well-known urban agriculture project in the Greater Miami area. In this chapter, I examine the spatial politics of Roots in the City as it struggled to address a host of community issues, including poor access to healthy food, unemployment, blighted environments, and looming large-scale redevelopment plans. I first elucidate how the Roots in the City case study contributes to critical geographic research on urban agriculture and community food projects. I then discuss how shifts in Miami's broader political economy have given way to neoliberal forms of urban governance and planning. Next, I document the trajectory of the Roots in the City project as urban development in Overtown opened and foreclosed its possibilities. Finally, I conclude with a discussion examining the spatial politics of gardening in Miami's inner city following generations of racist urban policy as Overtown hung at the edge of looming redevelopment. I argue that despite its pitfalls, the Roots project reflected aspirations to appropriate land and state resources, historically denied to Blacks in Overtown, to not just provide impoverished

\footnotetext{
${ }^{60}$ Ignatius Murray, interview by author, 5 June 2015, Overtown garden, Miami, FL.
} 
residents with basic needs, such as food and jobs, but also enact a spatial imaginary alternative to the vision of those invested in Overtown's gentrification.

\section{The Spatial Politics of Urban Agriculture}

In recent years, urban agriculture has garnered considerable academic attention. Much of this work, as McClintock (2014) discusses, sits in either of two camps. On one side, a large body of scholarship extols the ways community food projects "reconnect production - consumption linkages separated by the industrial food system" (McClintock 2014, 152; see also, for example, Jarosz 2000; Lyson 2012), invoke a "right to the city" politics of reclaiming urban space (Eizenberg 2012; Mares and Pena 2010), foster multiethnic and intergenerational exchanges of food and horticultural knowledge (Kurtz 2001; Baker 2004), and spur a suite of benefits, like increasing access to fresh food, building community, creating jobs, beautifying derelict spaces, and mitigating greenhouse gases, among others (e.g. Ackerman et al. 2014; Specht et al. 2014). At the other end, a more critical literature raises concerns about community food projects and their complicit relationship with neoliberalism. Some scholars take issue with the mushrooming of food nonprofits and civic volunteers filling in social safety net gaps left by the rolled-back welfare state, effectively buttressing the neoliberal austerity state while promoting neoliberal discourses of self-help, entrepreneurialism, and volunteerism (Guthman 2008; Pudup 2008). Others critique urban agriculture's relationship with gentrification, such as Quastel's (2009) study demonstrating the facility with which community gardening has been coopted by corporate developers to add value to condominium projects. 
However, as McClintock advises, "to debate whether urban agriculture is neoliberal or radical invokes a false dualism," as it is inherently both, arising out of the contradictions of neoliberal capitalism and working in dialectical tension between its subversion and reproduction $(2014,157)$. It is therefore more useful to examine the socio-spatial processes through which urban agriculture emerges while considering how it reconstitutes or perpetuates the existing "power geometry" (Massey 1994). Research by Ramirez (2015) has been particularly helpful in moving us beyond the radical versus neoliberal binary, as she aims to understand the spatial politics and imaginaries expressed through community food projects and the extent to which they acknowledge and respond to racial histories. This work is deeply informed by Black geographies, a growing body of research that intentionally centers Black spatial practices within critical analyses of resistance under racial oppression (McKittrick and Woods 2007), as well as recent critical food scholarship that considers the way race is performed and held stable in food spaces (Slocum 2007; Alkon and McCullen 2011). This chapter builds on these new directions by investigating the shifting spatial politics and practices of Roots in the City in the context of Miami's neoliberal urban development.

\section{Neoliberalism and Urban Development in the World City}

As Roots in the City's neighborhood gardens grew on one side of the tracks, on the other side downtown Miami was on the cusp of an economic boom. With Miami growing as a critical hub of global trade, capital investment, and banking, especially in the Latin American and Caribbean region, the city's economic and political elite were determined to attract mobile global capital by establishing and marketing Miami as the "Gateway of 
the Americas" and, most importantly, as a "world-class" city. Federal interest rates had fallen to historic lows by the turn of the century, and corporate developers were able to take advantage of Miami's relatively low property values, a result of starved capital investment during the 1980s and 1990s (Gainsborough 2010). Dozens of high-rise condominiums and commercial projects shot up, seemingly overnight, producing the nation's third tallest skyline. In line with what Hackworth and Smith (2001) have called “third wave gentrification," this rapid growth in real estate and commercial development was orchestrated largely through public-private partnerships between local governments and corporate developers. As scholars of neoliberalism discuss, the increased cooperation between public and private sectors since at least the 1980s reflects a broader shift in the function of city governments, moving from a managerial role to an entrepreneurial role and stimulating business and economic activity in contrast to provisioning public services (Harvey 1989; Mayer 1994).

The economic boom created a ripple effect in neighborhoods surrounding Miami's downtown and financial district, including Midtown, the Design District, Wynwood, and Overtown, where government and developers colluded to spur urban regeneration. Recognizing Overtown's vulnerability to gentrification, in 2001, the Knight Foundation made an unprecedented investment in the community, awarding \$19 million in grants to thirty-two local organizations involved in affordable housing, job training, and community revitalization. The rise in nonprofits and private foundations shaping revitalization in cities is also characteristic of the broader shift towards neoliberal urban governance since the 1980s. 
As part of Knight's funding, the Collins Center for Public Policy, a Miami nonpartisan think tank, received \$3 million to create the South Florida Smart Growth Land Trust and fund Overtown's Civic Partnership and Design Center (CPDC). In 2002, the Collins Center hired Philip Bacon as their vice president and executive director of the CPDC based on his experience involving the private sector in master planning as the manager of the Fort Lauderdale CRA. Under his direction, the land trust immediately purchased several tracts of vacant land, the result of prior condemnation, in between Overtown's historic Second and Third Avenue strips. Upon doing so, they became the second largest landowner in Overtown, after the SEOPW CRA.

Since the SEOPW CRA's first master redevelopment plan was drafted in 1982, this land was envisioned to be developed into a "Historic Folklife Village," a smallerscale, mixed-use cultural and entertainment district featuring affordable housing and a commercial corridor. In 1998, New Urbanist architects updated the master plan and created renderings of low-rise residential and commercial buildings, walkable streets and pathways, and public spaces reflective of the neighborhood's history. Bacon and the Collins Center, however, had grander plans for the area, believing a major development was needed to catalyze revitalization and overcome Overtown's image as a ghetto plagued by crime and decline. The Collins Center's revitalization plan, according to Bacon, "had three legs:" historic preservation; a civic partnership center (the CPDC), which would have "places where residents could help to reimagine the physical development [of Overtown]"; and a \$60-70 million equity fund called American Ventures, which would provide developers with substantial loans to help finance costs for large projects. 
Having worked with Michigan-based developer, Crosswinds Communities, Inc. once before, Bacon invited them to submit a proposal for a large-scale mixed-income housing unit on CRA-owned land adjacent to the future Folklife Village. In 2004, Crosswinds proposed Sawyer’s Walk (initially “Downtown Overtown”), a \$220 million, 1050 unit condominium and the largest ever residential project proposed in Overtown. The City of Miami was highly supportive, and Miami mayor Manny Diaz considered the proposal "a windfall," stating "it would lure middle-class people, and their incomes and tax revenue, back to Overtown, administering a revitalizing jolt to a depressed area" (Viglucci, 2006). SEOPW CRA chair and District 5 Commissioner Arthur Teele, whose district included Overtown and Miami's other predominantly-Black neighborhoods, however, objected to the development. The Power U Center for Social Change, a community advocacy organization, filed litigation on grounds that the residential development, including those parts sectioned off for "affordable housing," was "racist and classist" in that it would be economically out of reach for the average Overtown resident and thus promote gentrification (Viglucci 2006, 1B). Amidst persisting conflict between the Collins Center, the Crosswinds developers, public officials, Power U, and community activists, the Sawyer's Walk project remained stalled for the next few years, which, because it was a critical component of the Collins Center's revitalization plan, subsequently stifled momentum for development on various parcels they owned in the proposed Folklife Village. 


\section{Laying Down Roots}

In 2004, Roots in the City also received Knight Foundation funding $(\$ 200,000)$. Dunn incorporated a landscape training and employment program into his beautification and edible gardening projects, hiring people he described as "difficult to employ." Two years later, while redevelopment in Overtown remained largely uncertain, Roots was donated two acres of vacant parcels owned between the Collins Center and CRA (see Figure 5.1 and 5.2). The terms, as Dunn described them to me, were "one, we would not fence it [the property], which I didn't want to do to begin with. Second that, we would vacate the land whenever the city wanted it back within two months. In the meantime, we could use their property as long as they didn't get cited for trash or not keeping it up. We also had to provide corporate insurance in case of any injuries that might occur on the property. ${ }^{61}$ In other words, Roots was free to use the land so long as they abided by city code and left once the land was deemed saleable or ready for development.

Despite Roots in the City not securing actual property rights to the land, they felt their land tenure was relatively stable for the next few years, especially given the standstill with Sawyer's Walk and the lack of other major developments in the pipeline. In fact, a 2008 internal review of the Knight Foundation's investment acknowledged the failure of their "top-down strategy" to foster revitalization (Oliver 2008, 3). Equipped with ample land and a substantial budget, Dunn envisioned Roots in the City growing into an urban agricultural model for slowing gentrification: "This kind of project has long-term potential. [...] We would like to expand it so that other communities in South Florida will join the project and make good use of their open and vacant spaces and not

\footnotetext{
${ }^{61}$ Dr. Marvin Dunn, interview by author, 29 April 2015, Dunn’s home, Miami, FL.
} 


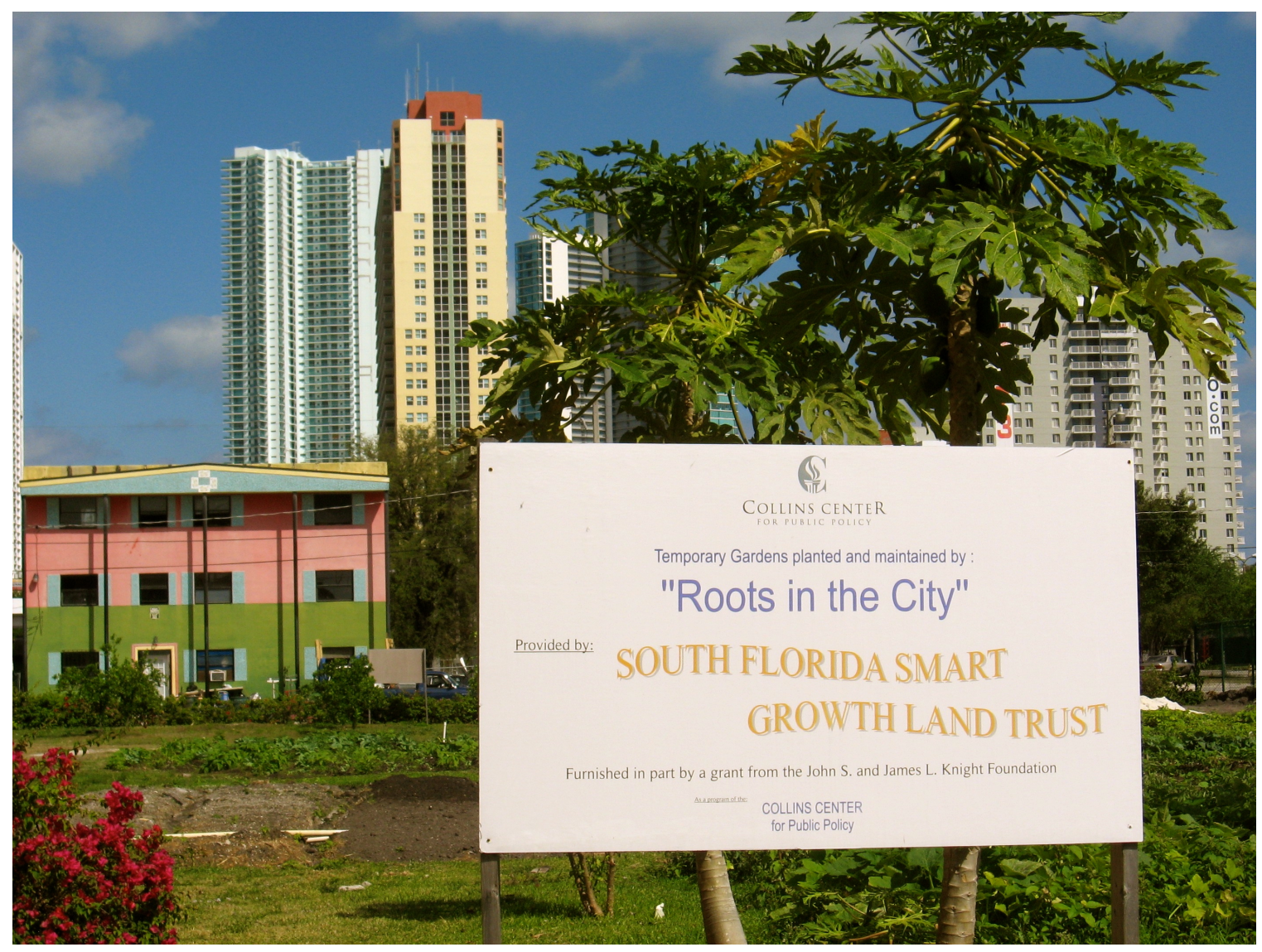

Figure 5.1: Roots in the City with downtown condos in the background. Photo by Gail Hollander.

be so quick to put new buildings in those spaces" (Burnett 2009, 1A). Roots planted their largest garden to date and used the newly acquired land as the primary site for worker training and community events. The project garnered wide support. In 2007, Dunn applied for and received $\$ 100,000$ from the CRA to develop his horticulture and landscaping program, a grant Roots continued to receive annually for the next three years. Roots in the City later received a one-time grant of $\$ 50,000$ from Allegheny Franciscan Ministries, an entity that continues to fund Overtown nonprofits. He also partnered with several local and corporate organizations, such as the Overtown Youth Center (an agency of former Miami Heat star Alonzo Mourning's foundation), 


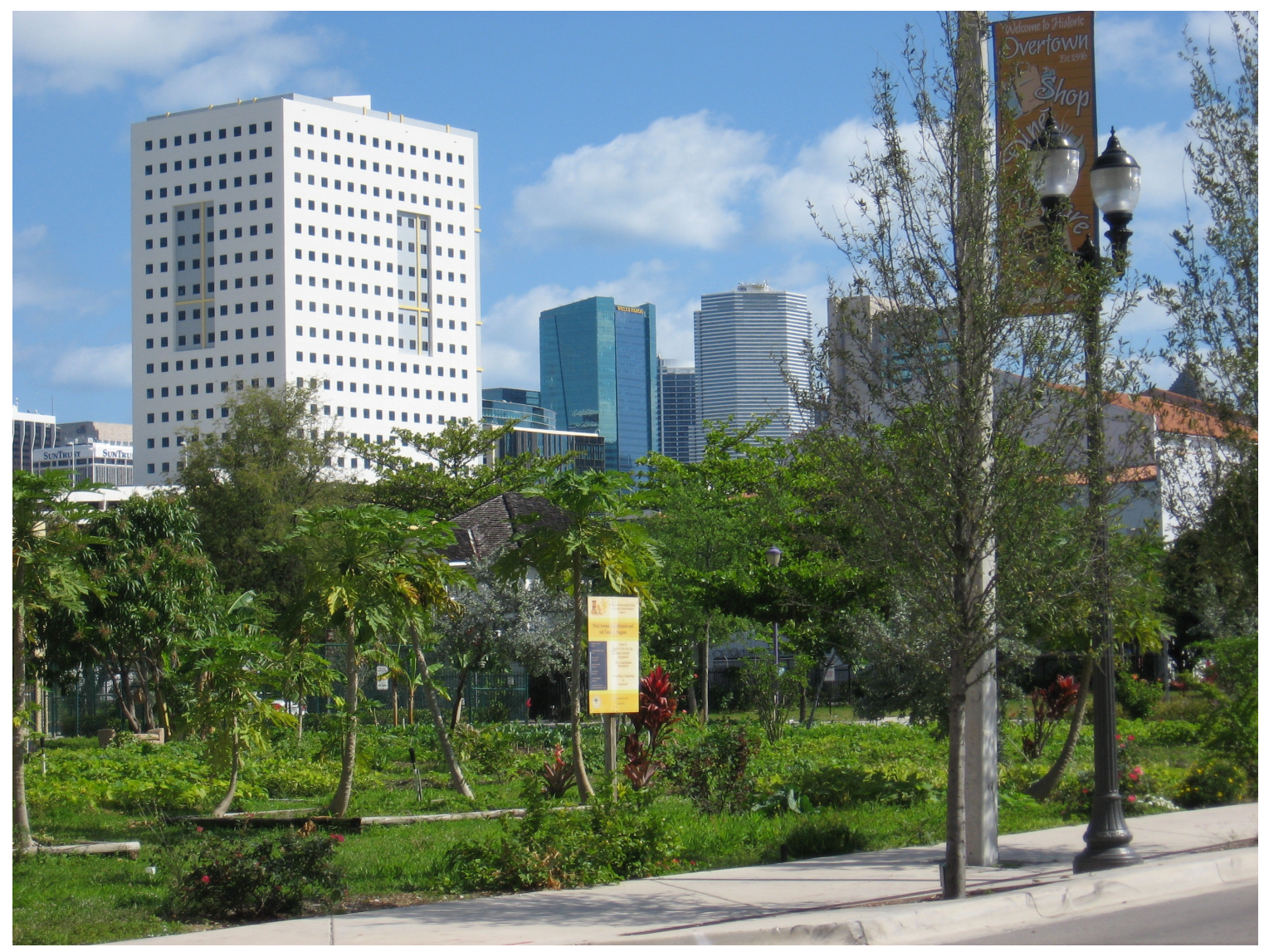

Figure 5.2: Roots in the City. Photo by Gail Hollander.

Hands On Miami, Touching Miami With Love, [...] United Way had people come out. But then certain businesses sent people out. Uh airlines, banks will have their employees have a work day in Overtown. The reason that they came to us was because we're the site that was big enough to absorb a lot of people to work at a given moment. So we could take 150 volunteers on any given Saturday. It took some planning, of course, to be ready for that many people but Roots in the City was an attractive volunteer site because of the scale of the project. ${ }^{62}$

Before long, the garden contained several rows of vegetables and herbs and a small orchard of mango, banana, papaya, and orange trees. Organizationally, Dunn oversaw operations as an unpaid executive director, while the primary caretakers of the

${ }^{62}$ Dr. Marvin Dunn, interview by author, 29 April 2015, Dunn's home, Miami, FL. 
garden were Murray, nine other full-and part-time workers, and Maggie Pons, a committed volunteer from outside the neighborhood.

According to Dunn, the produce grown by Roots was initially available for free to nearby residents. Then on a balmy October Saturday in 2009 , Roots introduced a weekly farmers market to Overtown. The market drew modest interest over the next few months, its small clientele a mix of neighborhood residents, downtown professionals, and local food enthusiasts. By the end of the South Florida growing season, however, the Roots in the City market had heightened its visibility, partnering with the Human Services Coalition (now known as Catalyst Miami), a community-building nonprofit in Miami, and nationally-recognized local chef Michael Schwartz. Since the mid-1990s, Schwartz had become part of a small cadre of chefs pioneering Miami's foodie culture. The James Beard Award-winning chef built his career working as the head chef at Miami Beach concept restaurants like Nemo and afterglo, the latter claiming to source wild and organic ingredients with "high syntropy values" (Woods, 2005, 3MB), and as the owner of Michael's Genuine Food and Drink, which had become something of a mecca for foodies and celebrities, located in Miami's gentrifying Design District. Schwartz expanded the Roots market, bringing in two farmers from nearby Homestead, and helped it receive sponsorship from chef Michel Nishan's national Wholesome Wave program, which gives food stamps (or SNAP) users double value on purchases at farmers markets. Through this sponsorship, the Roots market became the first inner city farmers market in Florida to accept food stamps. With the Roots market drawing wider attention, a dedication 
ceremony was held for the market in April 2010 featuring Miami mayor Tomás Regalado and District 5 city commissioner Richard Dunn (no relation to Marvin Dunn). ${ }^{63}$

For Roots and their partners, the market was an effort to reconfigure South Florida's food system and connect local farmers directly to communities with low access to fresh produce. "For me it's a way to support the growers and bridge the gap for growers to be able to sustain their business," said Schwartz in an interview with the Miami Herald. "We've always known many of these people were living in food deserts. This is going to revolutionize the food preparation methods and health of people who live in the neighborhood," added Daniella Cava, chief executive of the Human Services Coalition (Walker 2010, 1A) ${ }^{64}$ Overtown residents also weighed in, dispelling notions that African Americans prefer eating unhealthy food. Said one resident, "They think we're swine people, but a lot of us like to eat healthy food. On \$40 a month, I've got to really stretch it. I prefer to eat fresh vegetables. I just can't afford it” (Ibid.). Corroborating this sentiment another resident, a Haitian earthquake survivor living in Overtown, added, "It's a luxury to buy fruits and vegetables" (Ibid.).

In 2011, Roots was awarded a Farmers Market Promotion Program (FMPP) grant of $\$ 70,000$ by the USDA to expand its production, purchase supplies, make additional hires, and extend market hours. As part of the White House's Let's Move campaign, the \$10 million FMPP gave "funding priority to the development and expansion of direct producer-to-consumer marketing outlets that sell healthy foods in food deserts ... or low-

\footnotetext{
${ }^{63}$ Reverend Richard Dunn was appointed to Spence-Jones's position while she was suspended during a criminal indictment that would eventually be dismissed.

${ }^{64}$ Daniella Levine Cava was also elected to the Miami Dade County Commission in 2014. Human Services Coalition has since changed their name to Catalyst Miami.
} 
income areas (where the percentage of the population living in poverty is at least 20 percent)." The Human Services Coalition also received a FMPP grant of almost $\$ 87,000$ to brand and promote the Roots in the City market and seven other city markets equipped to accept food stamps. Things looked promising for Roots, which was earning $\$ 20,000$ annually through market sales and direct sales to restaurants like Michael's Genuine Food and Drink. According to Dunn, Roots also donated about one-third of its produce to local residents (Rabin and Burgess 2011). But like an unexpected South Florida storm, darker clouds would soon appear.

Having established a customer base and greater visibility within Miami’s local food movement, Dunn sought to expand and intensify operations and transform the gardens into an urban farm. On several occasions, Dunn made requests to the CRA for more land as well as a grant increase to $\$ 245,000$. But with Spence-Jones removed from office, Marvin Dunn's relationship with the CRA had weakened, and commissioner Dunn was less receptive to the Roots project. In March of 2011, the Roots market and another market in nearby Liberty City were shut down by the city for the illegal sale of fruits and vegetables. When market operators brought the issue to the city, they were told the markets conflicted with the city's zoning code and required a $\$ 153$ special events permit each time to operate. At this point in time, Miami did not have a permitting system for farmers markets. Upon receiving the violation, Marvin Dunn said, “'I'll tell you what, ... I'm gonna open up ... and I won't be selling the food. We're just gonna give it away. People just come and get it. We've grown it. What are we gonna do with it? So we're just 
gonna give it away.' Uh... rather than throw it away." ${ }^{65}$ The following Wednesday, the market's vendors and other food activists held a public demonstration at the market site to bring attention to Miami's lack of support for farmers markets at a time when cities across the US were implementing policies and programs to bolster local food economies. Various news outlets covered the peaceful demonstration, "attract[ing] a lot of television attention to the fact that we were being forced to give this food away, not just throw it away, because of the city's policies. ${ }^{, 66}$ During the demonstration, city officials told reporters that the proper permits did exist, which would amount to $\$ 73$ for unlimited use for nonprofits. "We were told that you can get a special use permit two times a year," stated Dunn in a newspaper interview (Niño 2011). "Now they're saying you can get an unlimited special use permit. When did that happen? We didn't get that message." Dunn later described to me that the confrontation "kind of poisoned the waters ... with me and [mayor] Regalado and some others at the city." ${ }^{67}$

A week later, the Herald released a series of articles documenting a feud between Marvin Dunn and Commissioner Richard Dunn. According to CRA spokesperson David Karsh, commissioner Dunn and other CRA officials felt their annual investment of $\$ 100,000$ in the Roots project was not producing sufficient employment results, having graduated less than fifteen percent of the promised sixteen workers in its training program (Rabin and Burgess 2011). Marvin Dunn reported receiving a phone call from John Townson, a former chef who ran a garden project and small produce store in Liberty

\footnotetext{
${ }^{65}$ Dr. Marvin Dunn, interview by author, 29 April 2015, Dunn’s home, Miami, FL.

${ }^{66}$ Dr. Marvin Dunn, interview by author, 29 April 2015, Dunn’s home, Miami, FL.

${ }^{67}$ Dr. Marvin Dunn, interview by author, 29 April 2015, Dunn’s home, Miami, FL.
} 
City, about forming a partnership. Townson envisioned opening a commissary and selling Roots' produce as well as operating mobile kitchens, or food trucks, and selling prepared foods to longshoremen working at the Port of Miami. Upon visiting Townson's garden and produce center, though, an unimpressed Dunn rejected the offer. In response to the Herald's initial coverage, Marvin Dunn submitted his own editorial:

For 14 months, the CRA refused to act on our request to make the garden into a true urban farm... I refuse to be coerced into a relationship with [commissioner] Dunn's political crony [Townson] for the $\$ 100,000$ grant. And given the $\$ 39$ million that the CRA has at its disposal, it is offering us peanuts. That's just enough to fail. We are developing an urban farm, a produce company and a farmers market. We need land. We need a dozen or more people to work full time. We need management capability, office space, a refrigerated truck, a warehouse, dozens of loads of top soil and more. (Dunn 2011)

The next weekend, students from Miami Dade College marched around the gardens, demanding the survival of Roots. One local resident stated: "When I was growing up, everybody here had a garden. This garden restores the history in Overtown." Said another: "I think the garden is a good attraction that we deserve. We don't have anything else. We don't have a Walmart and the nearest Winn Dixie is not walkingdistance" (Rabin and Burgess 2011). Despite a negotiating session taking place between Dr. Marvin Dunn and CRA officials, during the April 2011 CRA board meeting, the CRA voted unanimously to deny funding to Roots in the City. Several audience members expressed their discontent about the project's ability to create jobs, speakers which some have argued were planted by the city commission. 


\section{From Community Garden to Commodity Crop}

Once divested by the city, Dunn was forced to sustain Roots in the City on the cash sales of crops alone. By this time, the zoning and permit debacle had cleared up, and Roots attempted to maintain a weekly farmers market. However, according to Dunn, the

main problem with the farmers market in the ghetto is you can't sustain it on just the money that people in the ghetto have to buy the produce. You have to attract buyers from outside of the community. We got some of that but not nearly enough to sustain opening the market two days a week, weekend days. [...] Because having a farmers market on a Saturday and a Sunday meant three or four days of work leading up to that, so it wasn't just a matter of having people out there two days a week. [...] So that didn't work even though the local community, the Overtown response was very, very strong. ${ }^{68}$

In other words, the market was not generating enough revenue from the immediate Overtown community to pay for the labor and supplies required to run it. Murray added, "He [Dunn] wanted to do it like a community garden, you can supply the people. You sell them if they have money, and if they don't have money, you give it to them. But it didn't work. It couldn't work. ${ }^{\prime 69}$ Roots then turned to "farmers markets in upscale neighborhoods, in the Gables, on the beach and what have you.... We tried sending our produce and setting up stands in those farmers markets where the volume was there, but the logistics of it were overwhelming. Couldn't get moving people out, moving produce out, losing a lot of staff ... gotta have a truck, you gotta have drivers." ${ }^{, 70}$

Meanwhile, Dunn was dealing with theft in the Roots gardens, particularly of collard green plants. "The problem with collard greens in an open garden in Overtown

\footnotetext{
${ }^{68}$ Dr. Marvin Dunn, interview by author, 29 April 2015, Dunn’s home, Miami, FL.

${ }^{69}$ Ignatius Murray, interview by author, 5 June 2015, Overtown garden, Miami, FL.

${ }^{70}$ Dr. Marvin Dunn, interview by author, 29 April 2015, Dunn's home, Miami, FL.
} 
was that it's mainly attractive to African Americans. And people were ravaging the garden, just coming in and pulling up the plants, not harvesting the greens properly." Dunn then, "listened to some Caribbean friends who said, 'Try callaloo.' So we planted tons and tons of callaloo." ${ }^{71}$ Callaloo is a leafy vegetable green similar to spinach that is a popular feature in Caribbean dishes. The plant thrives in South Florida's subtropical conditions, requiring less manual watering than other leafy vegetables, such as collard greens, kale, or spinach. Although the Overtown community has always included Caribbean residents and Caribbean-descended people, callaloo “didn't attract people to come in and steal it.",72

With the farmers market now an economic dead-end for Roots, Dunn explored the possibility of a cash crop in callaloo: "I realized the callaloo grows and waters by itself pretty well, so we should capitalize on the easy nature of that plant." One Saturday morning, Dunn "walked into [the Haitian market] with about ten bunches of it. We had just harvested it that morning. It was gorgeous. So I go in, the place was packed with people, and women literally followed me into the freezer. They walked away from the callaloo that was being displayed by the market because it was wilted." ${ }^{, 73}$ Thereafter, Dunn began selling the plant to

mom and pop stores all the way into Broward County. They wanted callaloo. We couldn't grow enough of it. ... Up in Little Haiti especially, big demand for callaloo. Going up into northwest Dade where you have a lot of Jamaicans and other Caribbean groups. ... But ultimately we settled on one buyer who dealt primarily in callaloo who had his shop right across in Allapattah. Very easy delivering. In fact, he picked up the produce and

\footnotetext{
${ }^{71}$ Dr. Marvin Dunn, interview by author, 29 April 2015, Dunn's home, Miami, FL.

${ }^{72}$ Dr. Marvin Dunn, interview by author, 29 April 2015, Dunn's home, Miami, FL.

${ }^{73}$ Dr. Marvin Dunn, interview by author, 3 August 2016, Dunn's home, Miami, FL.
} 
then he took it to these mom and pop stores that we were dealing with, which was a much better deal for us. ${ }^{74}$

However, a few factors made this enterprise difficult. The plant has a relatively short window for harvesting and wilts very quickly. Callaloo also attracts a lot of insects, which feed on the leaves, leaving large holes. "So to grow a good quality product, we had to move to using insecticides or other kinds of control methods to protect that plant, but then you gotta produce it in such quantity that you need a lot of land to do it," said Dunn. Not only was he limited by acreage, his operation confined to a few urban parcels, but efficiently utilizing the land proved difficult without a reliable and consistent labor force.

I realized early on that a lot of people in Overtown who did not have jobs did not want permanent long-term jobs, in the sense that many of them were women who had kids who would have to make so much money to provide for themselves and their kids that to have a full-time job, they would have lost benefits. So I became aware of the fact that some folks needed money, but not so much money that they would become disqualified from the kind of support they needed, particularly health coverage for their children. So that made us more a part-time employment source for a lot of people over a period of time. So we had at one period maybe ten or fifteen people on the payroll, but they were not working full time. Two or three may have been, but many of them were coming in to help as crops came in, as we needed work done. A big problem was that the people we were hiring had drug problems, had drinking problems, had police problems, had records, and had limited skills in terms of what they could bring to the workplace. But those were the folks I wanted to try to find employment for. It seemed to me that if I could find something that people could use their hands and heads together-we had the resources and the land - that I might be able to put together a farming program that would provide employment for people who could otherwise not work. ${ }^{75}$

By this time, Murray had also moved to south Dade, and according to Dunn,

"getting him from south Dade up to Overtown to be able to supervise the crews and make

\footnotetext{
${ }^{74}$ Dr. Marvin Dunn, interview by author, 29 April 2015, Dunn’s home, Miami, FL.

${ }^{75}$ Dr. Marvin Dunn, interview by author, 3 August 2016, Dunn's home, Miami, FL.
} 
sure the produce was protected from insects and harvested within a reasonable - that became a big problem."76 Overseeing and executing these complex logistics to produce a commercial crop "became unbearable to manage" for Dunn, whose main professional focus was on his teaching and writing.

Murray described to me his perspective on the failure to maintain a viable cash crop operation:

We didn't had enough callaloo to supply the guy who was buying. We could sell a thousand bunch [each bunch sold for one dollar] every week. He would buy it just like that. ... But [Dunn] never had the land, you know, land space. ... When it comes to cash crop, one crop only lasts for ninety days, so you have to have enough land room to rotate. ... You can't have it this week and next week you don't have it. You can't keep a market like that ... And he didn't mechanilize [sic], he was doing everything manually. ... He didn't understand. I say, 'Let us buy a tractor, man. And let we go out and look for some land.' He say, 'No.' He want to do it around town [in Overtown]. He want to do it here. ... And then he take too much money and he turn over without make enough to cover the expense. He was having men working like, giving them fourteen dollars a hour, twenty dollars a hour. ... It doesn't work. You have a machine and the machine will do what ten men do. Twenty men do. ${ }^{77}$

Indeed, Dunn's main objective was providing jobs for Overtown residents, not trying to become rich as a farmer.

As Dunn struggled to keep residents employed through his callaloo farm, the CRA informed him of their intention to reclaim their portion of the land Roots had been donated. "They always told me they were gonna do it," said Dunn. "It was no surprise. ... I had irrigated and had put in all kinds of investments on that site, so once the CRA decided to put the housing there, trying to get that infrastructure on that scale and location

\footnotetext{
${ }^{76}$ Dr. Marvin Dunn, interview by author, 29 April 2015, Dunn's home, Miami, FL.

${ }^{77}$ Ignatius Murray, interview by author, 5 June 2015, Overtown garden, Miami, FL.
} 
[elsewhere] was just more than I wanted to try to tackle."78 By this point, Dunn had spent nearly twenty years working to beautify, feed, and employ Overtown and was not interested in starting over. In 2014, he decided to dissolve Roots in the City into Health in the 'Hood, his daughter's nonprofit, which has expanded its reach across several of Miami’s low-income African American communities.

"I'm getting out of here right now," Murray tells me. "“Cause they want all this for building."79 We are standing in a lot on Northwest Tenth Street where one of Roots' gardens used to be (see Figure 5.3). Rows of mulch and several garden beds dot the property, their cinder block edges the last remnants of Roots in the City's materials. At the time of my fieldwork in 2015, a young Jamaican man who went by "Juice" and worked with Roots, had been living on the property for a year and, along with Murray, grew mostly papayas, mangos, and pigeon peas. He also collected coconuts in a shopping cart and sold them to Overtown residents, which he would like to turn into a legitimate business.

In 2014, the property and several others owned by the Collins Center's land trust were sold for $\$ 4.77$ million to Lion Folk Life Village LLC, a firm owned by white Miami Beach-based developer Michael Simkins. The properties are mere blocks away from three major developments in motion: All Aboard's MiamiCentral, a hub for Florida's prospective high-speed train; Miami Worldcenter, a 30-acre mixed-use retail, luxury condo, and entertainment complex; and Simkins's Miami Innovation Tower, a sixty story LED billboard tower set within Simkins's proposed Innovation District, a 10-acre nexus

\footnotetext{
${ }^{78}$ Dr. Marvin Dunn, interview by author, 29 April 2015, Dunn's home, Miami, FL.

${ }^{79}$ Ignatius Murray, interview by author, 5 June 2015, Overtown garden, Miami, FL.
} 


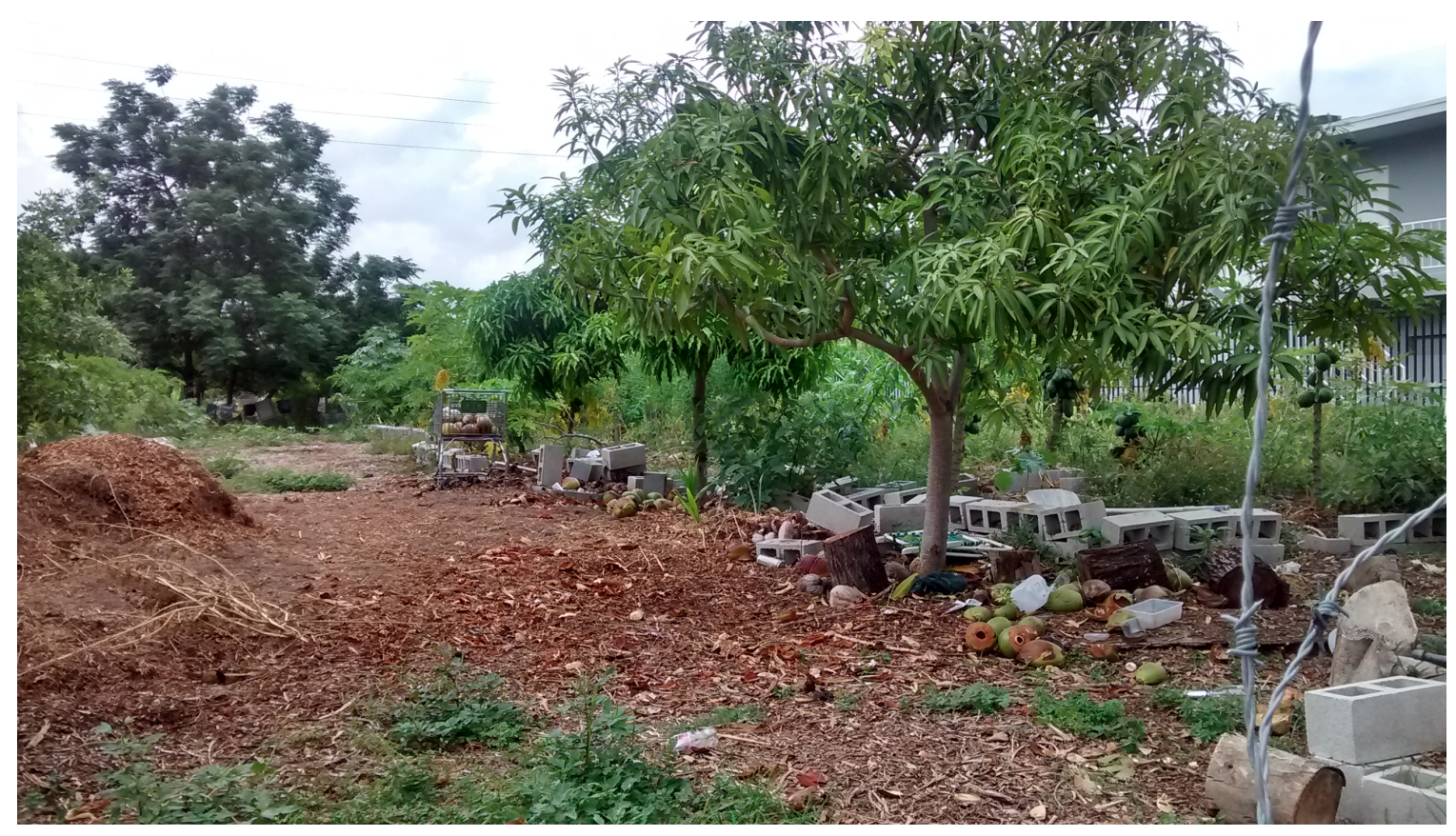

Figure 5.3: One of the former Roots in the City lots. Photo by author.

for tech companies. Simkins allowed Juice to live and garden on his property, but according to Murray “didn't want to have a lease that we would be sure to be here for a certain period of time. ... 'Cause, he want to build so... when he ready he don't want to have no problem getting people out of this site." ${ }^{80}$ Today, the land remains undeveloped, suspended in the midst of looming revitalization.

\section{Doing Inner City Space Differently}

In this chapter, I have explored the spatial politics of the Roots in the City project as it intervened in Miami's neglected inner city. As one of the leading historians of Black Miami, Dunn knew all too well the injustices bestowed upon Overtown. Though never a resident of the community, he was compelled to inspire change and combat Overtown's public image in the aftermath of the 1980s riots. What began as an effort to make

${ }^{80}$ Ignatius Murray, interview by author, 5 June 2015, Overtown garden, Miami, FL. 
university students confront and beautify the material detritus wrought by expressway construction, urban renewal, and public neglect morphed into a project that mobilized donated property, state resources, and extensive social networks to grow fresh food for residents, employ the unemployable, and create an alternative model of land use for impoverished communities on the brink of gentrification.

Despite its long run, it is unclear the extent to which Roots in the City played into the hands of a broader neoliberal development strategy. The CRA's minimal investment, the donation of unwanted land and a fraction of their annual budget, effectively beautified, maintained, and land banked an area once plagued with crime, ridden with debris, and now planned for capital-intensive revitalization. Roots in the City attracted thousands of visitors to Overtown, but failed to cultivate a politics of place that would ensure its survival once the land's "rent gap" (Smith 1987) was realized.

At the same time, it would be remiss to characterize the Roots project as unwittingly complicit with a neoliberal urban agenda. Though not without its pitfalls, Roots in the City demonstrated a different, if not experimental, way of "doing space" (Bondi 2005) or "doing property" (Blomley 2004) than the ontologically singular mode of urban redevelopment slated to benefit an elite minority. Dunn's vision for Roots in the City aligns with Lipsitz's conception of the "Black spatial imaginary and its socially shared understanding of the importance of public space as well as its power to create new opportunities and life chances" $(2010,52)$. Ramirez’s conception of “Black food geographies" is also helpful to think about the ways in which Dunn reimagined land in the lives of marginalized and dispossessed African Americans. While city officials, urban planners, and developers envisioned Overtown as a space to lure mobile capital into a 
cultural tourism district and large-scale housing project, Dunn viewed the land not as a commodity (Polanyi 1944) but as a productive, self-sustaining agricultural space that could rearticulate relationships between community, land, labor, health, and the economy. Though Roots in the City would ultimately dissolve, Dunn's project served as a powerful material and ideological beacon for Overtown and Miami’s rising food movement in Miami. 


\section{OVERTOWN IS GONNA BE THE PLACE TO BE: SHIFTING FOODSCAPES AND COMMUNITY REDEVELOPMENT}

Ray wakes up early in the morning, while the sun is still low. He gets dressed, watches a little TV, and scoops a couple handfuls of dry cereal into his mouth. He'd prefer to have his cereal with milk, but the rooming house where he pays $\$ 400$ a month to live does not provide access to the refrigerator, or any kitchen appliances for that matter (see Figures 6.1 and 6.2). After catching the morning news or the score of last night's game, Ray, a single man in his early fifties, walks down the front steps of his home and starts the day. Depending on how he feels, he might take the Overtown-Health District trolley over to Seventh Avenue and Northwest Seventeenth Street where a Miami branch of the Missionaries of Charity, or the "Sisters," serve a hot breakfast. Ray knows he can go there any day except Thursday, but dislikes waiting in the increasingly long lines of up to three hundred people. Sometimes Ray walks straight to the small grocery near his home and buys a tall can of blackberry-flavored Steel Reserve. He then makes his way to a nearby bus bench, sometimes referred to negatively as "Club 41 " because it is a regular hangout and drinking spot for men as they watch the 41 bus pass by. ${ }^{81}$ The 444 calories in Ray's drink carry him through the morning. On some days, Ray will drink three or four beers instead of eating.

Ray, who grew up “over town,” doesn't work, nor has he held a legitimate job for any consistent period of time in his life. In high school, he pushed marijuana and crack cocaine for larger dealers. At age eighteen, while riding home on New Year's Eve his moped collided with another vehicle, and he spent the next three months in the hospital.

\footnotetext{
${ }^{81}$ The number of this bus route has been changed for this dissertation.
} 


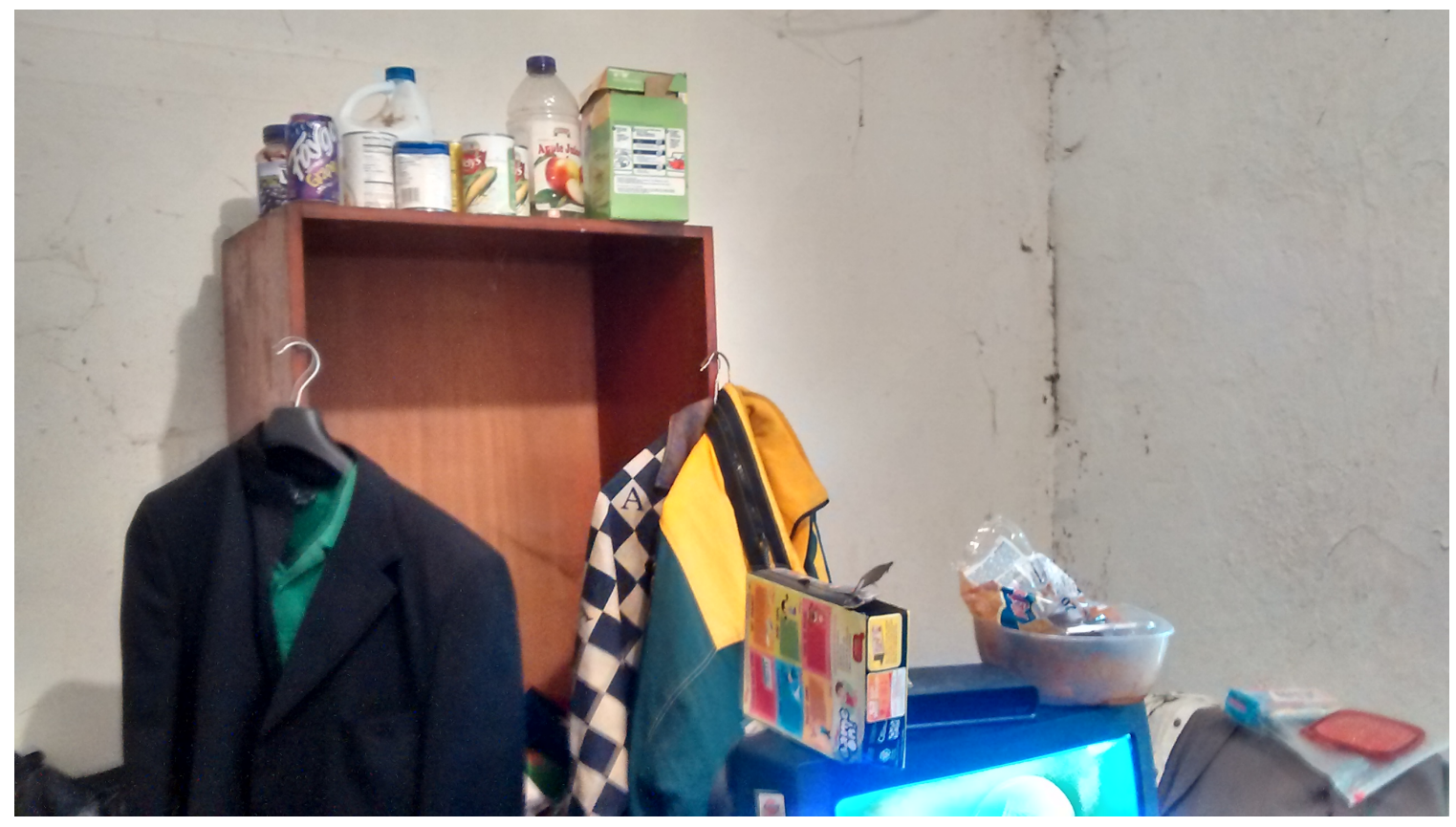

Figure 6.1: A corner of Ray's room. Items include clothing, a TV, bread, cereal, apple juice, canned food, and soda. Photo by author.

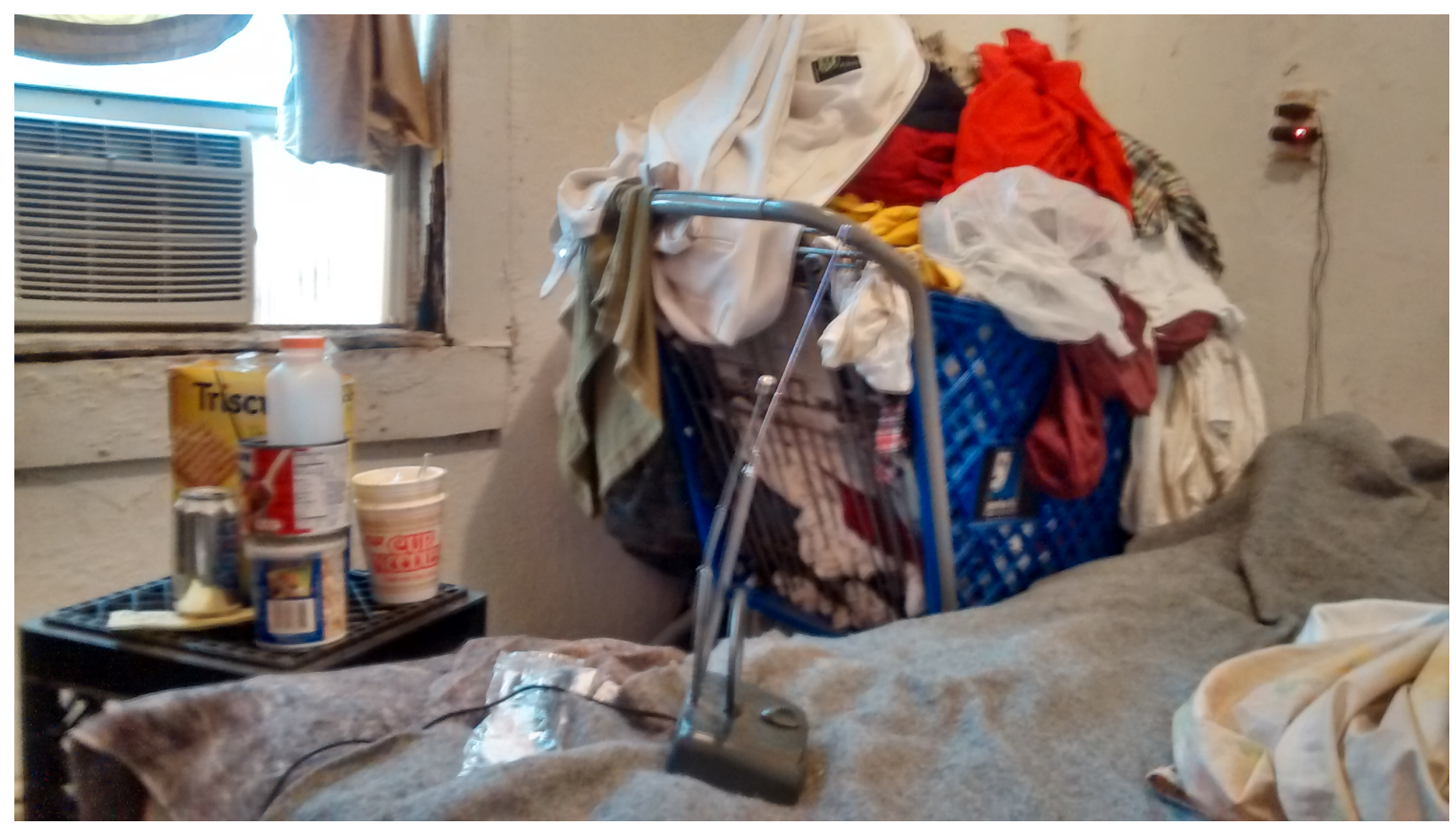

Figure 6.2: Another corner of Ray's room. A cart full of clothing, bed, TV antenna, microwaveable noodles, crackers, canned food, and juice. Photo by author. 
The accident damaged his central nervous system, and Ray had to relearn to walk, taking Quaalude to numb the chronic pain. Because of the accident, Ray receives a monthly disability check for the rest of his life, most of which is gone after he pays the rent for his ten by ten foot room. Today, Ray still walks with a noticeable hobble, and has trouble covering long distances.

Sometimes for lunch, Ray visits Two Guys Restaurant, an unassuming quickservice joint that serves burgers as well as a mix of Southern and Caribbean dishes out of a decaying building. Ray likes the place because he can "cut side deals" with Shirley, the owner. For two or three dollars he can get a plate of rice and a little meat, "one or two pieces" depending on "how she was feeling" that day. On other days, Ray might take the Overtown circulator bus to a Winn Dixie supermarket, located west of the I-95 expressway and another five blocks beyond the neighborhood's edge. At Winn Dixie, he slyly approaches the prepared food cases, carefully discrete and avoiding eye contact with workers. When the moment strikes, he snatches two or three fried chicken tenders and shoves them into his pocket. Perhaps if he were allowed to purchase hot food with the $\$ 171$ he receives every month in food stamps, or SNAP benefits, he would. But this is where the USDA has drawn the line, despite the fact that some people who participate in SNAP have limited or no access to functional kitchen appliances. Without a refrigerator, a stove, or an oven to store and prepare food, Ray's monthly SNAP allotment is virtually useless for personal consumption. To make better use of his benefits, Ray often sells exchanges them for cash or purchases food for single mothers. But to meet his daily food needs, he relies on charitable or informal food networks and the five-finger discount. 


\section{The Rise of Food Charity}

By now Ray has committed to memory the various times and places where he can get a hot meal or a bag of ready-to-eat canned and packaged foods. The Miami Rescue Mission is his favorite place because they "feed good," a common expression among the poor used to describe food charities. Every other Thursday he visits the St. John's Baptist Missionary Church, which gives out bags of food. On Saturdays Grace in the Park Ministries, a "mobile ministry" visits Overtown to hold service and serves food at a park just one block away from his home. If he has the time, however, Ray prefers to take a bus six miles northwest to a church that provides a filling breakfast that might include grits, eggs, corned beef hash, croquettes, or fish. They also "serve lunch on Wednesday at 12 o'clock, and they give out free bags of food on Thursday. They give out way more food than those people got," he says, pointing to a nearby Overtown church. ${ }^{82}$ On the day I met Ray, he was carrying a Styrofoam container of food provided by the Temple Missionary Baptist Church, which gives out lunches on Tuesdays. On this particular Tuesday, they served macaroni topped with balls of sausage, a side of corn, and a slice of red velvet cake. When asked how often he gets food from one of these charitable providers, Ray replied: "It depends if I fucked up my money," meaning whether he has spent it all before the month ends. ${ }^{83}$ Since I met him in November 2014, Ray has always spent (or lost) the little remains of his disability check during the first week of the month, often on drugs or time with sex workers. For Ray, who has always lived in poverty and has no future

\footnotetext{
${ }^{82}$ Ray, interview by author, 4 November 2014, Overtown bus stop, Miami, FL.

${ }^{83}$ Ray, interview by author, 4 November 2014, Overtown bus stop, Miami, FL.
} 
prospects for improving his conditions, having a few hundred dollars affords him a small window to temporarily escape his reality.

Food charity has been a longtime feature of Miami's inner city. In the last few decades, however, it has played a far more central role in delivering emergency food assistance to low-income people. Scholars have charted the expansion of food charity in advanced industrial countries since the late 1970s, when public social safety net programs were first cut back, reformed, or wholly dismantled and the food retailing industry restructured itself spatially in cities (Curtis and McClellan 1995; Poppendieck 2014; Riches and Silvasti 2014). Between 1970 and 1992 the maximum benefit for Aid to Families with Dependent Children, the US's primary cash assistance program, declined forty-three percent when adjusted for inflation (Curtis and McClellan 1995, 98). The Personal Responsibility and Work Opportunity Reconciliation Act of 1996 undermined key facets of the Food Stamp program, the nation's leading food resource, terminating benefits for the unemployed (among other eligibility restrictions) and thereby eliminating "a publicly funded unconditional right to food" in America (Poppendieck 1999). The Center on Budget and Policy Priorities described the act as "probably the single harshest provision written into a major safety net program in at least 30 years" (Edelman 1997).

Similar to emergency food aid sent to the global South, food charity, especially as privately-funded and corporate-sponsored, is symbolic and symptomatic of the neoliberal response to the declining welfare state amid growing food insecurity and hunger-and poverty more generally - in the global North (Riches and Silvasti 2014). Since 2007, food insecurity rates among US households have shot up by three percent (ERS USDA 2015) - about 10 million more households - which many attribute to the global economic 
meltdown of 2008, the 2007-2008 world food crisis (and the ongoing volatility of global food markets), and rising social and economic inequality. Although federal programs like the Supplemental Nutrition Assistance Program (SNAP, formerly the Food Stamp Program) and school breakfast and lunch programs still comprise the largest portion of food assistance in the US (Hall 2015), many people are unable to meet their food needs through public assistance alone. Charitable food providers are often the only providers of hot meals for adults, and because so many adults have neither the time nor the resources to prepare food at home (or are homeless), food charity has become a vital piece of the US anti-hunger landscape.

Among the network of charitable food providers serving Overtown and its immediate surroundings are larger missions and shelters as well as an array of neighborhood churches. From my interviews with employees from the Miami Rescue Mission and Camillus House I discovered that both are generously funded by the private sector, though not entirely, and offer shelter and housing programs to the poor and homeless. Camillus House was originally founded in 1960 by the Catholic congregation, The Little Brothers of the Good Shepherd, who established a small overnight shelter and soup kitchen for newly arriving Cuban immigrants (Camillus House 2016). Since then the organization has grown to become a central node in Miami's charitable service network. In 2012, they moved from their original location just east of the railroad tracks that make up Overtown's eastern edge to an $\$ 80$ million, state-of-the-art complex on the western edge of Overtown. The seven building campus contains a clinic that offers direct care services, an industrial kitchen facility, warehouses, offices, and hundreds of apartments for residents in their housing and treatment programs. In addition to providing 
emergency, transitional, and permanent housing, Camillus House also runs a six to eight month substance abuse treatment program for some 400 residents, where in return residents provide labor for the maintenance, cooking, landscaping, and warehousing departments. Although they provide food to their residents and members of their programs, their programs do not typically offer food charity to visitors. ${ }^{84}$

The Miami Rescue Mission, established since 1928, provides a similar set of services and operates in three locations across South Florida. During my visit to their Miami branch located at the boundary between Overtown and Wynwood, I spoke with two full-time food service employees to learn about the organization and the work they do. Similar to Camillus House, the Mission is a large complex encompassing several buildings, including a center for women and children, a men's shelter, a health clinic, a community activity center, and a food warehouse. They serve about 800 meals a day across breakfast, lunch, and dinner to sheltered residents and between 200 and 500 dinners to outside visitors. It was explained to me that they tend to receive more visitors toward the end of the month, as many people have spent up their social security and disability checks. ${ }^{85}$

The Miami Rescue Mission is one of the largest organizations doing food charity in Miami. They operate with an annual budget of $\$ 23$ million, most of which comes from private donors. They have a wide network of direct suppliers, including Gordon Food Service, the largest privately held food service distributor in North America, and PepsiCo. In addition, they also have a team of drivers who make regular pickups from

\footnotetext{
${ }^{84}$ Information provided by Alfonso, interview by author via telephone, 4 March 2016.

${ }^{85}$ Information provided by Greg and Mike, interview by author, 29 May 2015, Miami Rescue Mission, Miami, FL.
} 
Walmart, Publix, Winn Dixie, and twenty-two 7-11s, all of which donate unused, previously cooked, and close-to-date food. "It's a lot of logistics. We have a wide network of donors. A lot of people know us," said one of their food warehouse workers. ${ }^{86}$ To round out the nutritional content of meals, the Mission also purchases about ten percent of the food in their warehouse. When I asked if they felt they had enough food to serve healthy meals, I was told that, while no client has ever been turned away, there are shortages in the kinds of food that are served. Good produce, for instance, is hard to obtain because what is donated is usually canned or close to spoiling. The food service supervisor in charge of putting together the weekly menu stated that he tries to make sure there are fresh greens and other vegetables, as many of their clients suffer from diabetes and other diet-related health issues. ${ }^{87}$

During a tour of the food warehouse, I was able to see the large walk-in refrigerators and freezers stocked with tall stacks of meats, produce, spices, and packaged foods. The Mission also has the resources and equipment necessary to pick up and deliver large quantities bulk food items, making them a valuable partner for other charitable food providers. In addition to providing meals to their own clients, the Mission also supplies other smaller charities and churches in the area with extra food they collect. For example, on Mondays they deliver half the food they pick up from Publix to the Missionaries of Charity, a women and children's shelter and soup kitchen founded by Mother Teresa in 1980.

\footnotetext{
${ }^{86}$ Greg, interview by author, 29 May 2015, Miami Rescue Mission, Miami, FL.

${ }^{87}$ Information provided by Greg and Mike, interview by author, 29 May 2015, Miami Rescue Mission, Miami, FL.
} 
Food charity thus comprises a vital part of Overtown's food landscape. Hundreds of people from Overtown and the immediate area rely on the major food charities like the Miami Rescue Mission for basic daily sustenance. Yet while most of Overtown residents live in poverty, food charity tends to be accessed by the most destitute, such as the unemployed, the homeless, and single parents. Based on my field observations and conversations with food charity workers, there also appears to be a gendered aspect to food charity. It is predominantly men who frequent the larger charities serving regular hot meals while women tend to rely more on the local churches that supply packaged goods. This has much to do with the way household structures in Overtown have evolved in the wake of punitive policies and practices that limit work opportunities for and disproportionately incarcerate Black men. For instance, a 2006 survey sampled 129 adult men in Overtown and reported that sixty percent were unemployed, nearly two-thirds earned less than $\$ 15,000$ annually, nearly two-thirds had been incarcerated, nearly half had not graduated high school, and more than a third had "lived on the streets" (Collins Center 2006). Meanwhile, according to census data, there are more than six times as many female-headed family households in Overtown as male-headed ones. Women are tasked more often with providing food for other household members (Allen and Sachs 20012; Bell and Valentine 1997), which explains at least in part why they are more likely to procure grocery items as opposed to single hot meals.

\section{The Rise of the CRA}

In the last decade or so, Overtown's foodscape has also begun to change as a result of increasing public investment in the neighborhood, in this case through the efforts 
of the area's CRA. CRAs are quasi-state entities designed to stimulate urban revitalization in distressed communities. First appearing in California at the end of World War II, they were created to provide local governments with the authority, tools, and resources "to declare areas as blighted and in need of urban renewal" (Blount et al. 2014, 1). In Florida, they became authorized through the 1969 Community Redevelopment Act, or Florida Statute 163.330. CRAs function by creating "special purpose districts that are institutionally separate from local government, with special powers to raise public funds and leverage private capital" (Jonas and McCarthy 2009, 305).

Since the 1980s, tax increment financing, or TIF, has become the chief means of financing local redevelopment. TIF works by freezing the property taxes of a CRA's district at the time of creation and then channeling all subsequent increases, or "increments," in the tax base each year to the CRA. In addition, CRAs can issue bonds to private investors and developers upfront based on projected incremental revenues to set the development process in motion. The idea is that the TIF monies CRAs use to make improvements and investments will end up raising property values inside the district, further increasing the tax base and creating a self-sustaining cycle of economic growth, until the CRA is no longer needed.

In 1982, after several years of community planning, the SEOPW CRA was created to address the rampant poverty conditions and "continuous pattern of disinvestment and abandonment within ... Overtown" and to expand Miami's downtown district northward (SEOPW CRA 1982, 1). The joining of Overtown's southeast area with the Park West area abutting Biscayne Bay (see Figure 6.3) in the creation of the SEOPW district was justified on the basis that a TIF program could not be financed 


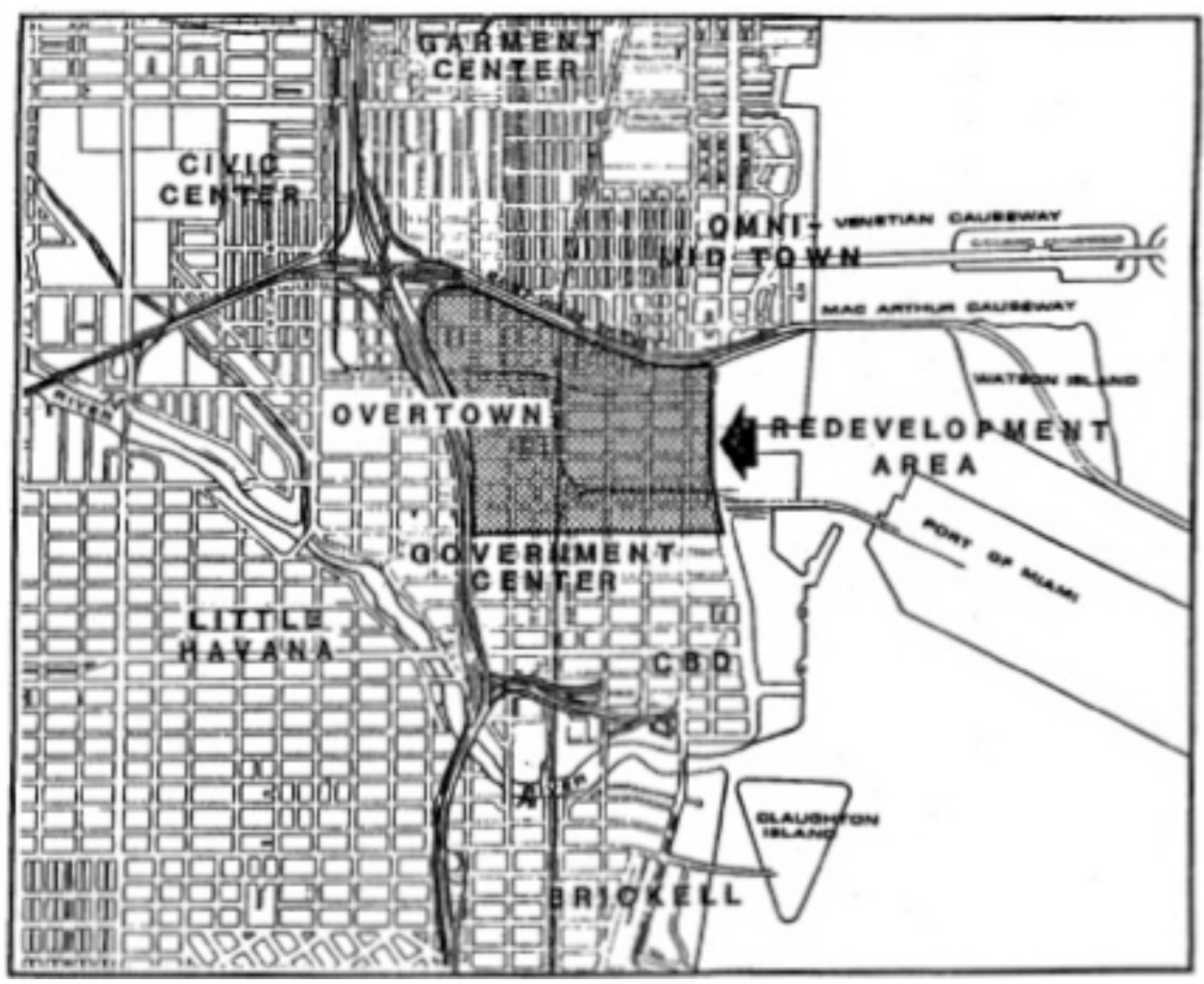

Figure 6.3: Original SEOPW redevelopment area. Reprinted from the 1982 SEOPW CRA redevelopment plan.

through Overtown's tax base alone and required leveraging the yield from taxes on higher value properties closer to the central business district and water's edge. In this way, Overtown's redevelopment has always hinged on the prosperity of the Park West area across the railroad tracks, an area whose tax base was expected to be augmented due to its proximity to anticipated projects in neighboring regions like downtown, OmniMidtown, Brickell, and the Port of Miami. 
Despite the putative "win-win-win" strategy between government, the private sector, and low-income residents, in its first twenty years the SEOPW CRA accomplished very little in terms of redevelopment. A 2003 front page Miami Herald article reads: "The city's Community Redevelopment Agency, charged with reviving parts of the historic black community, has spent almost $\$ 35$ million in the past decade without financially spearheading a single major housing development. Only five of its 36 proposed projects have been completed" (Corral 2003). In the mid-2000s, however, seat changes to Miami's city commission as well as booming real estate development in the central city led to stronger direction and increased revenues for the SEOPW CRA. As Marvin Dunn described to me,

The biggest change was when Michelle Spence-Jones came into power because she used the CRA in ways that Art Teele [a former commissioner] did not. She started making decisions that led to improvements that were visible on the streets $[\ldots]$ and you could see the difference in how the streets were cleaned up. When we first started going into Overtown, the streets were filthy. Second Avenue and Third Avenue were repugnant. It was bad. Spence-Jones stopped that. So you saw the community appearing cleaner. She spent money on beautification. Façade improvements, other kinds of things that she moved forward, other affordable housing efforts started under her. She pressed for companies that got contracts to hire blacks. $^{88}$

Today, the CRA operates with an annual budget of $\$ 51$ million. In addition to financing the demolition, rehabilitation, and renovation of older, worn out buildings in the last decade or so, the SEOPW CRA also plays the main role in subsidizing economic development in Overtown. Guiding Overtown's redevelopment is an effort to curate an urban cultural district that conjures a history of Overtown as a thriving entertainment and

\footnotetext{
${ }^{88}$ Dr. Marvin Dunn, interview by author, 29 April 2015, Dunn's home, Miami, FL.
} 
dining hotspot during the mid-twentieth century. According to the SEOPW CRA's most recent redevelopment plan (an update to the 2004 and 1982 plans),

The goal of the Historic Overtown program is to vitalize the rich history and culture of Overtown, thereby creating a sense of identity and community pride that will contribute to the economic and physical revitalization of the Overtown community. By examining the past, it is intended to identify those elements that once made Overtown the thriving, exciting focus for the Black community in South Florida, and to incorporate appropriate and productive elements of that past era into the future redevelopment plan. (City of Miami Planning Department 2009, 2, emphasis added)

The plan continues, elaborating on its goal to create a mixed-use Historic Overtown

Folklife Village, which would

Develop a magnet area within the target community for the purposes of: (1) re-establishing a special identity for Culmer-Overtown by focusing on one era in its history, the 'Little Broadway' jazz era; (2) to establish interest in the Afro-Caribbean heritage by encouraging tourism, trade and cultural exchanges. Develop these themes to attract night clubs and restaurants; programming special cultural events, designing signs, street furniture and public plaza spaces; and creating promotional literature for tourism and local marketing. (Ibid., 2).

In recent decades, the creation of cultural tourism destinations has become increasingly popular in strategies of accumulation and urban revitalization (Gotham 2005; Harvey 1990; Hoffman 2003). Here cultural production is "less a socioeconomic practice that follows in the wake of urban life, but is regarded instead as the motor of the urban economy" (Newman and Smith 2000). Cities draw upon an area's cultural and historical elements and market them to produce new spaces of consumption. Examples of this are visible in New Orleans's French Quarter, and, specifically in African American communities, in New York City's Harlem and Chicago's Bronzeville neighborhoods. 
In particular, gastronomy plays a key role in promoting what David Bell calls the

“hospitable city" (2007, 8; see also Bell and Binnie 2005; Neal 2006). For Bell,

Places to eat and drink have, in fact, come to occupy a central role in the production of new forms of city living associated with the revitalization of previously deindustrialized and rundown urban districts (Zukin, 1991), as well as with forms of so-called cultural tourism, including 'gastro-tourism' and what we might call 'party-tourism' and 'alco-tourism' (on the former, see Boniface, 2003). City-centre living is packaged and sold not only in terms of proximity to particular postindustrial forms of white-collar (or 'no-collar') work, but also in terms of access to consumption, cultural and leisure amenities, thereby revitalizing neighbourhoods previously affected by the move towards suburban and ex-urban relocation of housing, shopping and working (Jayne, 2005). City-centre eating and drinking have thus become important components of regenerating neighbourhoods, both in terms of attracting new residents and in terms of making them gastrotourism destinations (Esperdy, 2002; Franck, 2005). (2007, 9)

In Overtown, food is viewed as a major component of its burgeoning urban

cultural experience. When asked to project the next five years into Overtown's

future, one city official described to me:

In a year I see the area attracting more businesses, attracting more investors. [...] I think in five years Overtown is gonna be the place to be. I think Overtown is gonna be the place where, when you come to Miami, you're gonna wanna go through, you're gonna wanna eat some of the food, you're gonna wanna go to the Lyric Theater and catch a movie or see a show. That's a staple of the community. It's a cultural destination. So I see Overtown flourishing and really being you know an urban downtown. That's the best way I can see it, an urban downtown.

\section{Making the Food Destination}

“You ready, baby? OK, what you gonna have?” asks Stephanie, an African American women in her forties. On any given morning, Jackson Soul Food is cooking and serving up breakfast to its patrons, mostly a mix of longshoremen (if it's still early) and other working-class and professional Black men. The serving staff, most of whom are Black 
women, moves along the bar bringing juice, coffee, and warm plates of fish, eggs, and grits. The clinks and clanks of forks on plates cut sharply over the conversations of men at the counter discussing the news broadcasted from flat-screen televisions, all against a backdrop of R\&B and soul pop music flowing from overhead speakers. Photographs of celebrities and political figures like Muhammad Ali, Dwyane Wade, and Joe Biden posing with the restaurant staff adorn the walls. On weekends, Jackson Soul Food is flooded with people. "There might be sixty people on that side, and in here it's full. And outside there's people waiting to come inside," says Stephanie, a sister to the owner.

Over the past several decades, Jackson Soul Food has become an enduring institution in the Overtown community. Its origins begin in the 1940s inside a local church, where comfort food was served to residents of Colored Town. After a few decades, the restaurant passed to another family member, who eventually moved the business out of the church and started Jackson Soul Food on property purchased just a few blocks south. In its new location, “There was some tough times where it looked like we was gon' be shut down," stated Alonzie, an African American chef in his mid-thirties. "But we was able to pull through, you know, through everything, and a lot of just struggling, hustling, and just trying to grind and stay positive, and you know, things got better for us." 89

A turning point began when the CRA started to fund improvements for the business in tandem with surrounding neighborhood developments. "What I noticed," continued Alonzie, "is the city started taking an interest in building it up, building the neighborhood up, so now you can see there's a lot of condos around here. I mean back

\footnotetext{
${ }^{89}$ Alonzie, interview by author, 30 July 2015, Jackson Soul Food restaurant, Miami, FL.
} 
then you wouldn't even see people jogging in the morning, now you see that. Around the 2000s, early 2000s, you started notice the changes little bit. Right before Arthur Teele was here, before he passed away, they started to make some changes." ${ }^{90}$ As mentioned earlier, part of the CRA's redevelopment strategy is to raise the profile of existing restaurants in Overtown while attracting new ones that fit the theme of the "Little Broadway" era. Alonzie described his sense of the CRA's vision: "Back in the 40s, this used to be called like Little Harlem, 'cause all this was clubs and restaurants, and I definitely see it getting back to that. 'Cause that's the, when you talk to people from the CRA and you see the plans, that's what they see in the future. That's the vision. So that's why they're building up everything when you go down, you see them rebuilding everything., 91

Initial efforts to move in this direction started in the late 1990s under the late Arthur Teele. Teele was a Black Republican, born into wealth in Florida, who moved to Miami following a decorated career as the former head of the Urban Mass Transit Administration under Ronald Reagan and president of the National Business League, the largest African-American chamber of commerce. He won a Miami-Dade County commission seat in the early 1990s and, after losing a race for mayor of Miami-Dade in 1994, a City of Miami commission seat in 1997. As the newly appointed commissioner of Miami's District 5, which includes the Overtown, Wynwood, Allapattah, Little Haiti,

\footnotetext{
${ }^{90}$ Alonzie, interview by author, 30 July 2015, Jackson Soul Food restaurant, Miami, FL.

${ }^{91}$ Alonzie, interview by author, 30 July 2015, Jackson Soul Food restaurant, Miami, FL.
} 
Liberty City, and Upper East Side neighborhoods, Teele became the SEOPW CRA chairman $^{92}$ and declared it his mission to resuscitate Black business in Miami.

In practice, however, Teele's actions appeared questionable to many of his constituents and commissioner colleagues. During Teele's time as chairman, the CRA's only successful new development in the SEOPW district was the building of a few parking lots of about eight spaces each on parcels mostly adjacent to the Jackson Soul Food restaurant. The CRA also loaned the owners of the restaurant $\$ 50,000$ to buy from them one of the parking lots they had originally spent $\$ 150,000$ to build. A year later, the CRA helped Jackson Soul Food negotiate a contract with Clear Channel to receive $\$ 100,000$ a year in exchange for housing a billboard in the parking lot. The parking lots and the billboard, which advertised to passersby on Interstate-95, stirred much controversy and prompted an independent audit of the CRA's financial records. During a 2002 public hearing on the matter, Teele stated: "Something has gone dreadfully wrong in this city. And you know old habits are hard to break. This is the most racist fuc frickin' town that I've ever lived in, that I've ever visited. There is a total conspiracy against Black businesses in this town. [...] This town does not want to see Black people in business. [...] There is a quiet conspiracy to keep Black people out of business" (Nielsen 2002).

In 2003, the audit detailed several instances of suspicious activity related to hiring practices, expenditures, and business negotiations. These allegations led the Miami-Dade Police Department's Public Corruption Investigations bureau to conduct their own

\footnotetext{
${ }^{92}$ Since its inception, the City of Miami's five commissioners have always appointed themselves as the five members of the SEOPW CRA board, with the District 5 commissioner assuming the role of CRA chairman.
} 
investigation, which after two years resulted in Teele's arrest on charges of twenty-six accounts of public corruption, including receiving kickbacks of up to $\$ 100,000$ for giving out contracts. Five days after his arraignment, Teele took his own life with a pistol inside the Miami Herald headquarters. Many people, especially in the Black community, felt he had been unfairly targeted, given Miami's pervasive governmental corruption.

In 2006, with Michelle Spence-Jones as District 5 commissioner and CRA chairwoman, Jackson Soul Food received a grant of $\$ 780,000$, originally allocated in 2003 but suspended in the midst of litigation over the billboard placement, to renovate and expand their restaurant. Around this time, the restaurant passed to the Jackson Soul Food's daughter, Shirlene. Under her leadership, Jackson Soul Food has become Overtown's most successful business and, with a staff of more than forty, one of its largest employers. Originally, the restaurant was only open for breakfast, but with the increase in business now runs from breakfast until lunchtime three days a week and through dinner from Thursday to Sunday. The restaurant's expanded space has made it an ideal venue for birthday parties, weddings, meetings, and other community events. The remodeling of the kitchen also allowed Jackson Soul Food to expand more of the business toward catering. "Everything that the city really does, like every event that they have, if they have a groundbreaking, you know, we always the one they call. They integrate other restaurants in the neighborhood, too, but most of the time we're the one that they call a lot, 'cause, you know, we gon' make it look good, we gon' represent for us," said Alonzie. ${ }^{93}$ Jackson Soul Food also opened a second location in northern MiamiDade, has plans to start a new concept on the ground floor of the multi-modal

\footnotetext{
${ }^{93}$ Alonzie, interview by author, 30 July 2015, Jackson Soul Food restaurant, Miami, FL.
} 
MiamiCentral transit station currently under construction, and runs three pop-up stations at construction sites in Brickell and downtown Miami. Additionally, Shirlene recently purchased an old hotel and received an $\$ 850,000$ CRA grant to remodel it into a bed and breakfast.

Alonzie sees Jackson Soul Food's success as an indicator of positive neighborhood transformation:

It's [Overtown] changed tremendously, especially the people. Because back then [during the 1980s and 1990s] this neighborhood was real rough. I'm not even gon' lie to you - real rough. Certain people wouldn't even drive through this neighborhood, 'cause they rob, bust the windows, and ever since then, you know, it has changed. The people got better, we have more different groups of people here, like lotta Spanish, lotta Caucasian people. Now the neighborhood is way better, and, you know, we got different ethnic groups that come in here now. 'Cause usually it only be people from our neighborhood but now it's a lot of tourists. Some of them come from Homestead after they leave church. I know people that come from Palm Beach, Boca, all the way up in Broward that come down just to eat. They pass all them restaurants just to come here. Just the mentality of the whole neighborhood is different. Its not rough, its like everybody trying to uplift each other, so that's what its about now. ${ }^{94}$

For Alonzie, that other lighter-skinned ethnic groups and tourists are now visiting and living in Overtown is a testament to the neighborhood's improvement.

Surrounding Jackson Soul Food's growth and success are a number of developments and aesthetic improvements in and around the neighborhood, often partially or completely financed by the CRA, and oriented to attract more affluent tourists and residents. In 2016, Overtown witnessed its first ever mid-rise residential towers, developments made possible through $\$ 55$ million in CRA subsidies (see Figures 6.4 and 6.5). During a groundbreaking for one of the condos, Clarence Woods, the CRA's

\footnotetext{
${ }^{94}$ Alonzie, interview by author, 30 July 2015, Jackson Soul Food restaurant, Miami, FL.
} 


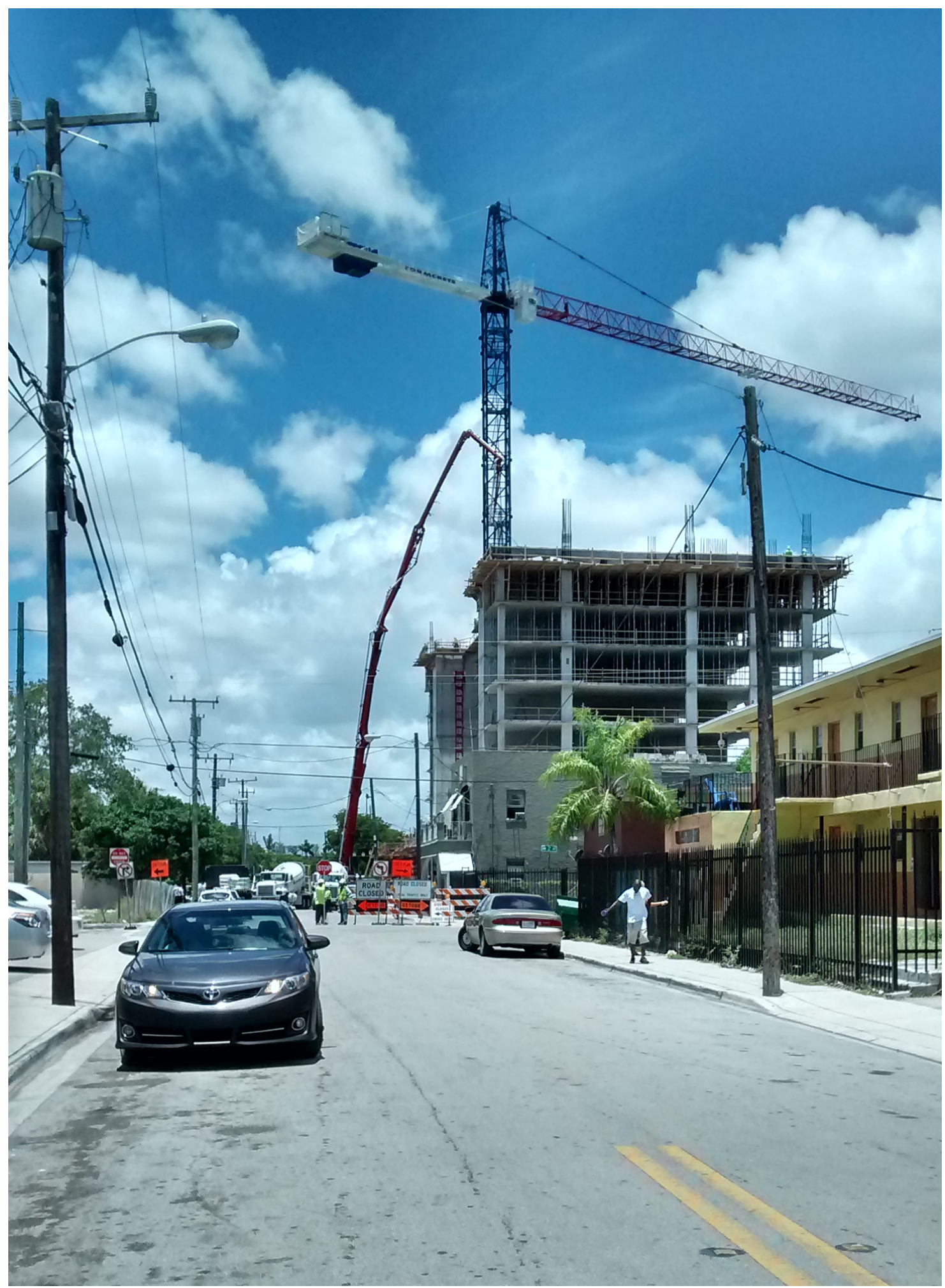

Figure 6.4: Construction of affordable housing in Overtown. Photo by author. 


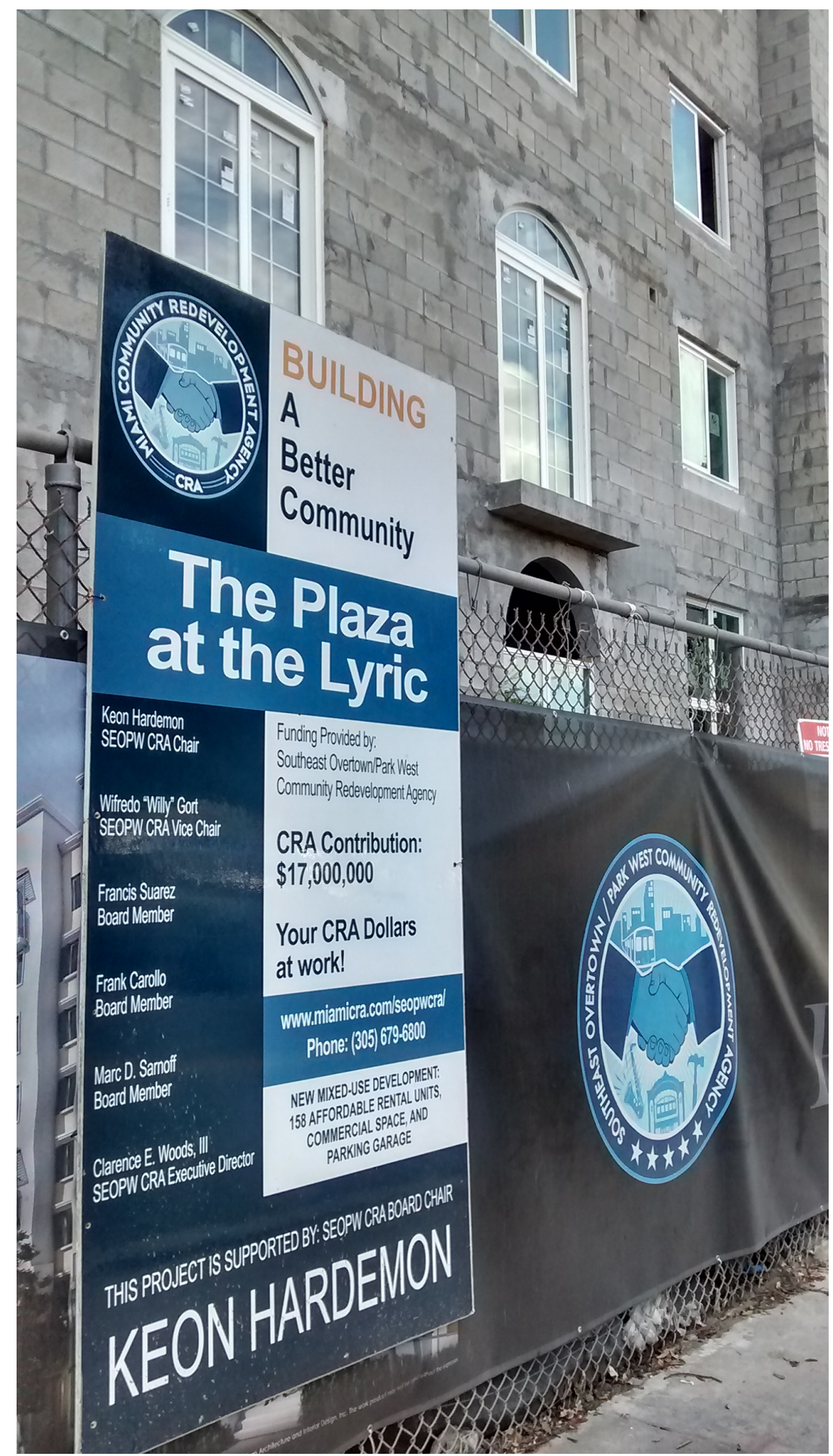

Figure 6.5: Construction of mixed-use development, Plaza at the Lyric, in the planned Historic Overtown Folklife Village. Photo by author. 
executive director, giddily announced to the crowd: 'We got cranes 'over town.' Tower cranes. A friend sent me a picture of the cranes from the 836 [one of the highways that connects to the interstate system that crosses through Overtown]. We got cranes that big in Overtown. That's progress." 95

In the past ten years, the CRA has spent $\$ 15$ million to rehabilitate more than 400 apartment units, \$11 million to revamp a local park, and \$6 million for renovations to the Overtown Shopping Plaza, the historic Lyric Theater, the Old Clyde Killens Pool Hall, and the Ebenezer Methodist Church, which has become repurposed into a performance center, kitchen incubator, and training facility for the Miami Dade Hospitality and Culinary Institute. In addition, the CRA has given the owners of longtime establishment People's Bar-B-Que a $\$ 1$ million grant to renovate and the owner of House of Wings, a quick-service joint, $\$ 1.25$ million to build Harlem Square, a supper club, on property where Clyde Killens ${ }^{96}$ once lived. These investments in Overtown's hospitality and entertainment infrastructure all correspond to redevelopment plans to create a Historic Overtown Folklife Village on land once known as "Little Broadway." Along with these investments, the CRA has created new branding for the Overtown community. CRA t-shirts, publications, and banners read: "Live Overtown," followed by the words "Eat," "Live," "Create," and "Grow" (see Figure 6.6).

In February 2016, the CRA declared Overtown the "new foodies destination" in a press release highlighting the success of existing restaurants and announcing interest from celebrity chef Marcus Samuelsson of Food Network TV fame in developing a

\footnotetext{
${ }^{95}$ Clarence Woods, 18 March 2015, groundbreaking event for Island Living Apartments, Miami, FL.

${ }^{96}$ During the fifties and sixties, Clyde Killens ran a radio station in Overtown and booked and promoted most of the entertainment for the neighborhood's various nightclubs.
} 


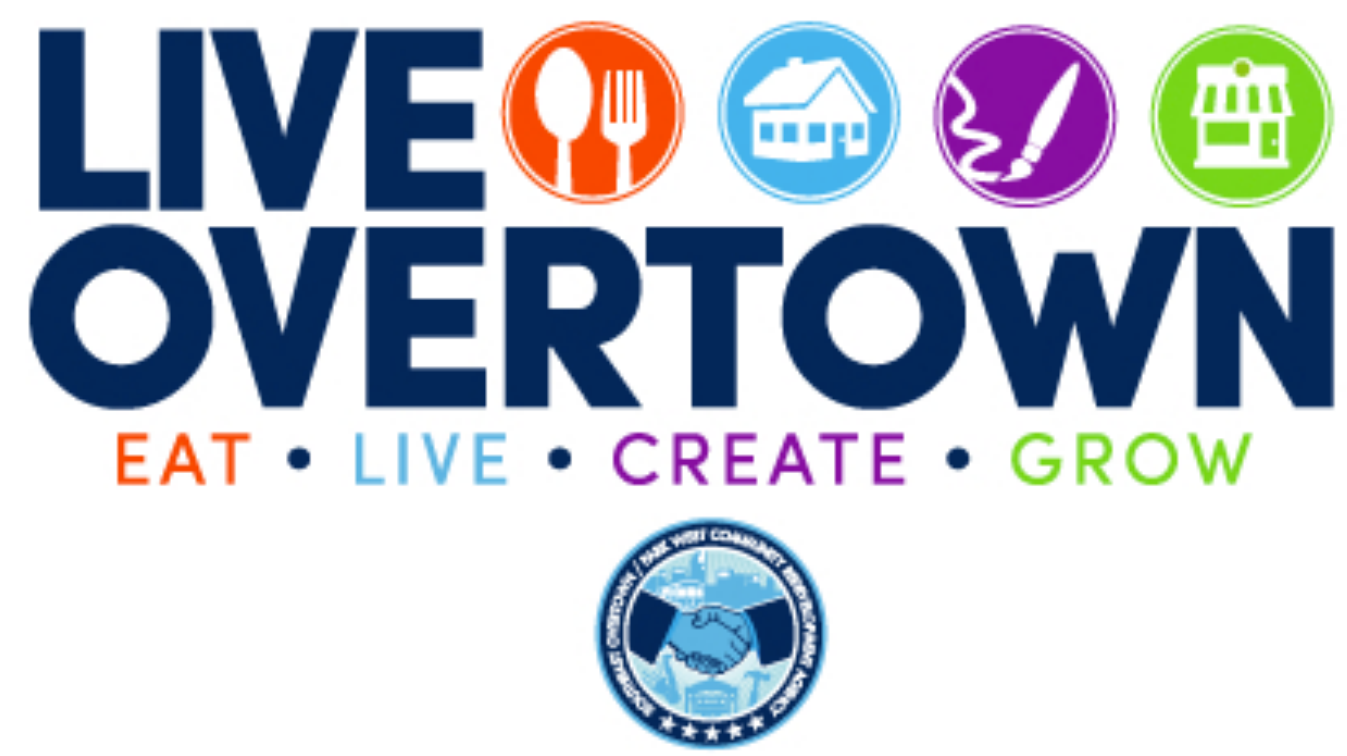

Figure 6.6: New branding for Overtown by the CRA.

restaurant concept in the newly renovated Clyde Killens Pool Hall. Samuelsson is an experienced restaurateur who pioneered Harlem's foodie scene with his acclaimed restaurant, Red Rooster, and food festival, Harlem EatUp. In their winning proposal to the CRA, the Samuelsson Development Group wrote: "We see the end use of the 7600 sq. ft. $920 \mathrm{SW} 2^{\text {nd }}$ Ave space as a premier dining and entertainment destination, embracing and inspired by the history of Overtown," and later added an objective to "Establish Overtown as a Food Destination" through collaborations with urban farmers, farmers markets, and the Miami Dade Hospitality and Culinary Institute (see proposal in Fagenson 2016).

It also deserves mentioning that in December 2014, the CRA agreed to subsidize the developers of Miami Worldcenter, a 27-acre retail, hospitality, and luxury condo mega complex located two blocks east of Overtown in the Park West area, to the tune of 
over $\$ 100$ million through the year 2030. In 2015, the mixed-use development, 3

MiamiCentral, broke ground on land at Overtown's eastern edge, acquired and sold to developers by the CRA. These large developments on the perimeter of Overtown were justified by the CRA on the basis that they will produce the necessary TIF funds to invest further inside the neighborhood's interior and rescue its people from poverty. During one governmental board meeting, city commissioner Hardemon addressed an audience concerned about the Worldcenter development:

All over this nation, the Black communities where you've been seeing the civil disturbances, in places like Ferguson, places like Baltimore. These places all have the same narrative, and that narrative is, "There is no investment in our communities. Our communities have no jobs." The homes are dilapidated. You see communities where poverty is the norm. And what you're seeing is a cry from that community to say that "We need more in this community for us to thrive. For us to live. For us to be productive citizens. And I've heard that cry for far too long, because I grew up in that very same type of community. [...] But I must say to you that $[\ldots]$ that community of Overtown where we're particularly discussing today is not like those cities. This community has an opportunity to invest hundreds of millions of dollars towards redevelopment. It has an opportunity to pump those dollars into a community that has never had it and never seen before.

But the question is, "How do we go about doing that?" [...] When people think about the Overtown CRA, they gloss over Park West. Park West has been the part of that CRA that has developed the most Tax Increment Finance dollars to start the development and redevelopment of Overtown. So the condos and the businesses that you see on the Park West side have always funded that redevelopment in the community that has traditionally been poor. Overtown in and of itself does not have the resources to redevelop its own community because they don't generate the type of tax dollars that we need. And I say that to you to say that because of that, we have to invest in the redevelopment of Overtown by developing Park West. When you invest one billion dollars, and I can guarantee you that in any other city around this nation, they're not investing one billion dollars into a Black community as such. But that one billion dollars in Tax Increment Financing that it will create will give us the opportunity to do more of what we're doing today. [...] We've invested \$1 million in the businesses of such: like People's Bar-B-Que for their complete redevelopment to bring more jobs, to create more of an 
industry there. We've invested in Two Guys Restaurant, we've invested in Groovin' Beans. These are places that are going to attract people to our community. Because you have to ask the question: What reason do you have to come to visit Overtown? ${ }^{97}$

In other words, Hardemon argues that not only does Overtown depend on its food and drink businesses to support its neighborhood economy, but that the making of Overtown's cultural dining destination is only possible through the development of megaprojects in neighboring Park West.

The question that remains however is, who is slated to benefit from Overtown's revitalization? For Alonzie, Jackson Soul Food has been a crucial pillar in his life. Alonzie has known the Jackson Soul Food family since the early 1990s, when Shirlene managed his youth R\&B group. "She just kinda raised me, 'cause my real family wasn't too much around. So she was a mentor in my life at that time [...] and then during the summers, I started coming in and working. Just being here in that twenty year period of time, since I was fifteen, I just learned to work in the kitchen." ${ }^{98}$ Alonzie first began working under his uncle, but became the head chef when he passed away. Like Alonzie and his uncle's relationship with the owner, "most of the people that are here are family, or they live in the neighborhood, like we probably know 'em for awhile, or its an extension of someone we know. We don't really hire too far out, you know we try to hire people we think we would trust." ${ }^{, 99}$ Having close ties to the business owners gives Alonzie a means of riding the wave of redevelopment. As for the recipients of large CRA

\footnotetext{
${ }^{97}$ Keon Hardemon, 14 July 2015, Miami-Dade Board of County Commissioners meeting, Government Center, Miami, FL.

${ }^{98}$ Alonzie, interview by author, 30 July 2015, Jackson Soul Food restaurant, Miami, FL.

${ }^{99}$ Alonzie, interview by author, 30 July 2015, Jackson Soul Food restaurant, Miami, FL.
} 
grants, all of them are landholders (of property that is rapidly appreciating) with strong, longstanding ties to the CRA and other powerful figures. The owners of Jackson Soul Food, People's Bar-B-Que, and House of Wings (each of which has received at least $\$ 1$ million in grants), for instance, own the properties they are fully subsidized to renovate or build on. The owner of House of Wings, a well-connected member of the Nation of Islam and co-owner of a successful marketing and promotions company, recently brought Louis Farrakhan to Overtown (his first time speaking in Miami in twenty years) and regularly invites music celebrities to visit the neighborhood.

Other businesses, however, have not reaped the same scale of benefits from the CRA's redevelopment agenda, presumably because they do not own property into which a justifiable major investment into Overtown's "brick and mortar" could be made. For instance, in 2015, Italian Ice by Denise and Groovin' Bean Coffee Bar \& Lounge, two tenants running food and drink enterprises along Overtown's commercial business corridor, received grants of $\$ 50,000$ and $\$ 150,000$ respectively to finance the build out of their stores.

In 2012, Shirley, who has run Two Guys Restaurant for more than twenty-five years, received a $\$ 260,000 \mathrm{CRA}$ grant to move her restaurant off of CRA-owned property and into a freestanding building owned by a local church. The building where Shirley was running her business was slated for condemnation to make room for an eight-story "affordable" housing project. In early 2013 , just days after the restaurant's build out was completed, the Florida Department of Transportation (FDOT) notified the building's owners that it would be using eminent domain to reclaim the property and expand the I395 expressway that ran close by. When Shirley approached the CRA for answers to her 
dilemma, they claimed that while they had seen earlier versions of FDOT plans, none of them showed the highway expansion overlapping over the property she would be occupying. In 2014, the CRA then gave Shirley a $\$ 150,000$ grant to transfer Two Guys to a unit in the renovating Overtown Shopping Plaza. In her new and bigger space, Shirley has been able to expand her menu and hire more staff. She has also raised food prices to pay for her higher rent. When I met with Ray, following the move of Two Guys, I asked if he had visited the new location. "Yeah, but I don't like it. I been dealin' with her for a while. Now she's in the back," he told me, meaning Shirley manages the kitchen and no longer handles transactions at the counter. "I can't get that stuff [the side deals] no more. Times have changed. People actin' funny." 100

\section{The Wrong Kind of Small Business}

"That's what I never got," said Etta Thomas, “a loan from the CRA."101 Etta's words reflect a situation that all of Overtown's grocers are currently facing. That is, their role in Overtown's redevelopment is uncertain at best and perhaps nonexistent at worst. At the time of this research, thirteen small groceries supply the community formerly vacated by supermarkets, making them Overtown's most common type of brick and mortar business. Most, if not all, of these stores have been open for more than a decade, with some dating back to the 1970s. Only a few are Black-owned, the rest run by Middle Eastern and Latino immigrants, as discussed in chapter four. Despite their relatively smaller selection and higher prices, these groceries are the only conveniently walkable

\footnotetext{
${ }^{100}$ Ray, interview by author, 12 March 2015, Overtown street, Miami, FL.

101 Etta Thomas, interviewed by author, 17 August 2016, Overtown grocery store, Miami, FL.
} 
option for residents, many who have limited access to private transportation, in search of basic goods.

Typically neighborhood groceries have no more than four aisles of goods and, based on field observations at six stores, carry a similar core set of products: canned and boxed food, water, milk, toiletries and cleaning products, lottery tickets, beer and malt liquor, cigarettes and other tobacco use products, and, of course, "pseudo foods" (Winson 2013), or the wide gamut of nutrient-poor products that include chips, cookies, and other salty and sweet snacks, sugary drinks, and carbonated beverages (see Figures 6.7, 6.8, and 6.9). Each store also sells additional items, tailored over the years to match customer preferences. Luis, for instance, a middle-aged Dominican man who has run a meat market and grocery in Overtown for nearly twenty years, has learned to stock his store with goods specific to the needs and preferences of Overtown residents. In addition to basic staples, his store offers various kinds and cuts of meat, including oxtail, neckbones, ham hocks, and chitterlings; fresh produce like apples, oranges, potatoes, onions, peppers, yucca, lima beans, and collard greens; and other items like made to order sandwiches, work shirts, and hair products.

Beyond supplying groceries, though, Luis plays many important roles in the community. Hanging out in his store, it is evident that he is beloved by many residents and cares about their well-being. Though he doesn't need to, he will purchase goods (mostly durable goods, like batteries, home health care products, and so on) for his store from underemployed residents who have acquired them through informal channels. In other cases, if a customer is unable to afford a needed good, he will often give it to them. 


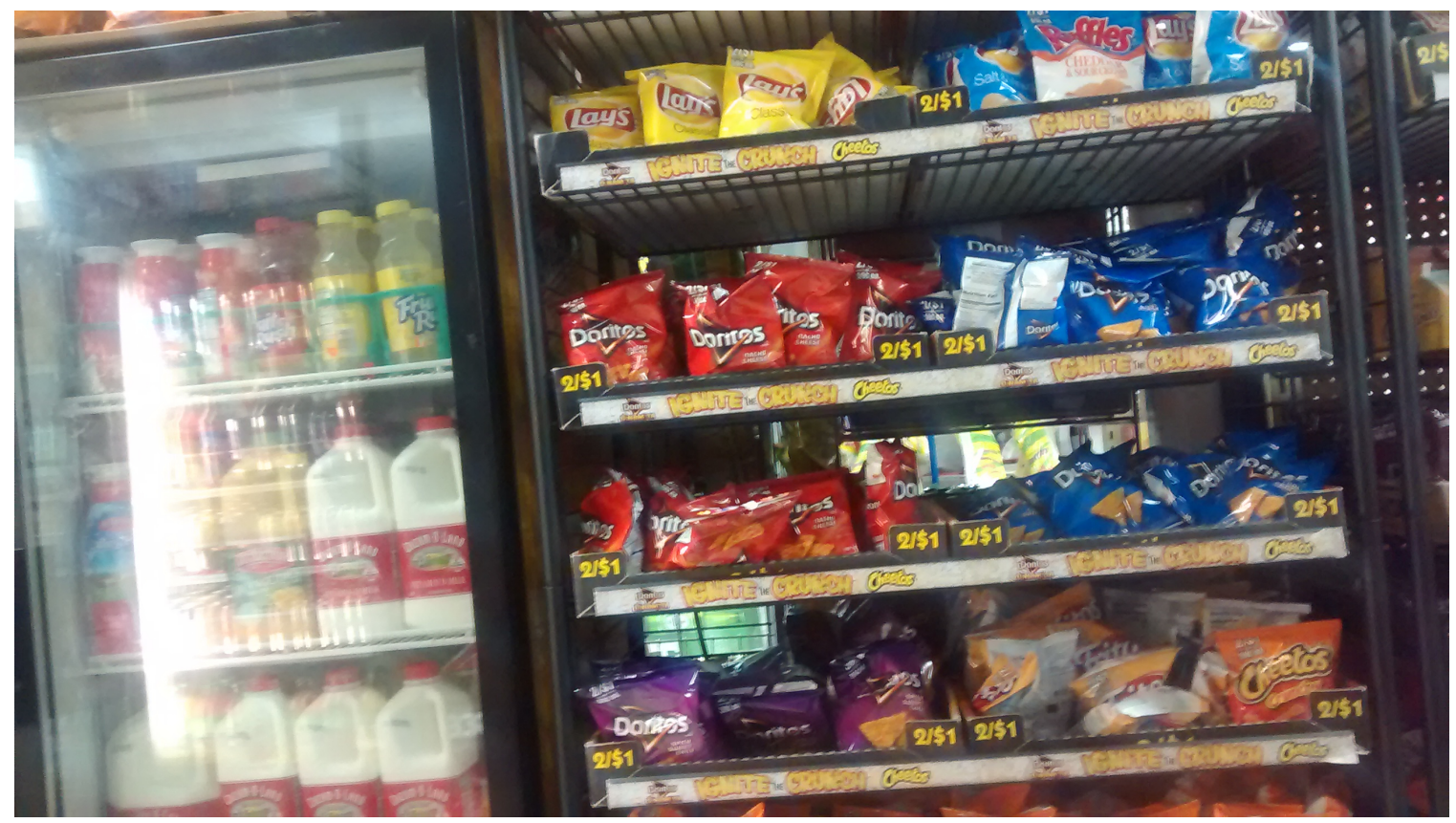

Figure 6.7: Chips, milk, and fruit drinks on grocery store shelves. Photo by author.

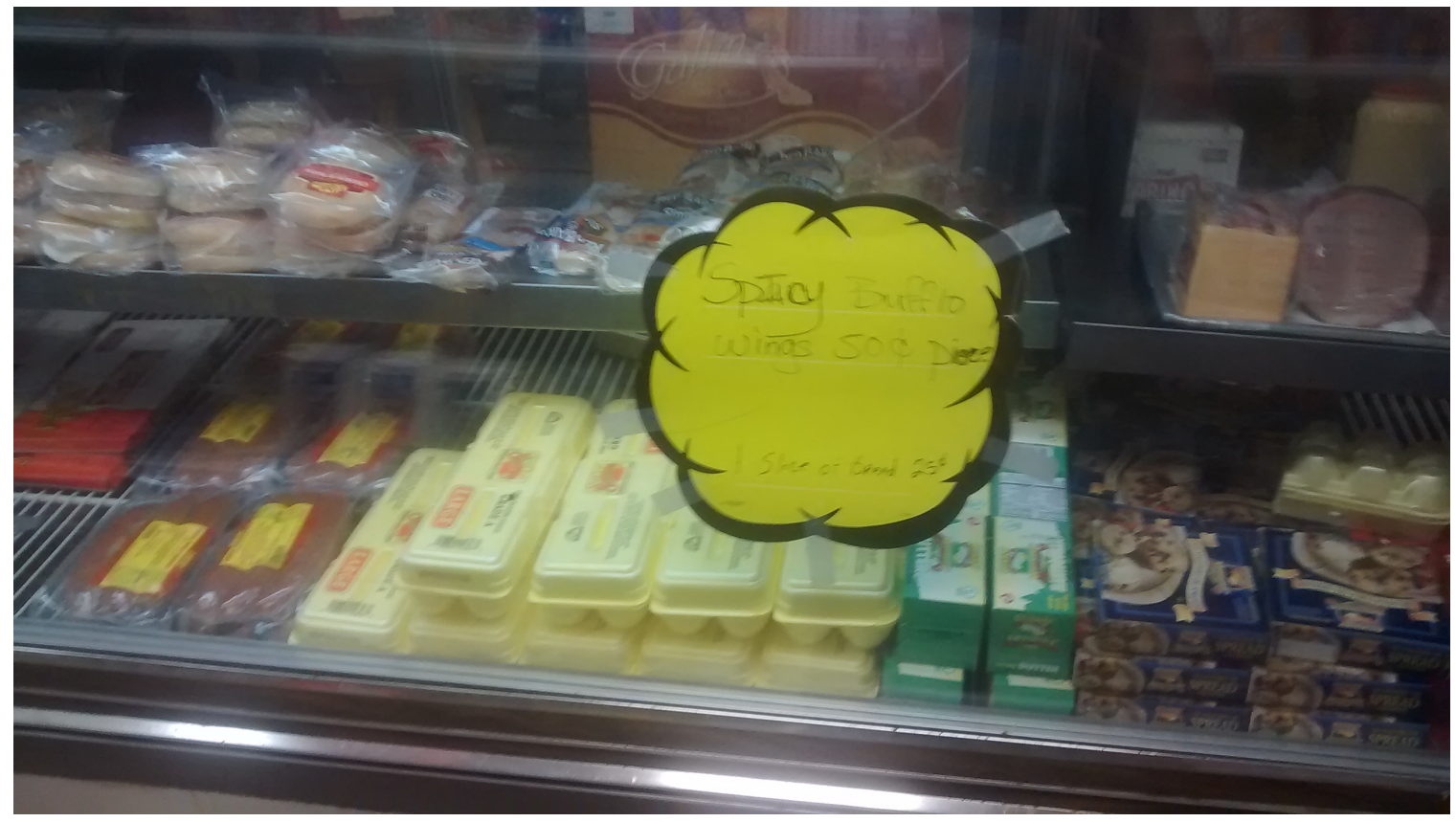

Figure 6.8: Eggs, meat, cheese, sandwiches, and other items inside a display case. A sign reads: Spicy Buffalo Wings 50ф piece / 1 Slice of Bread 25ф 


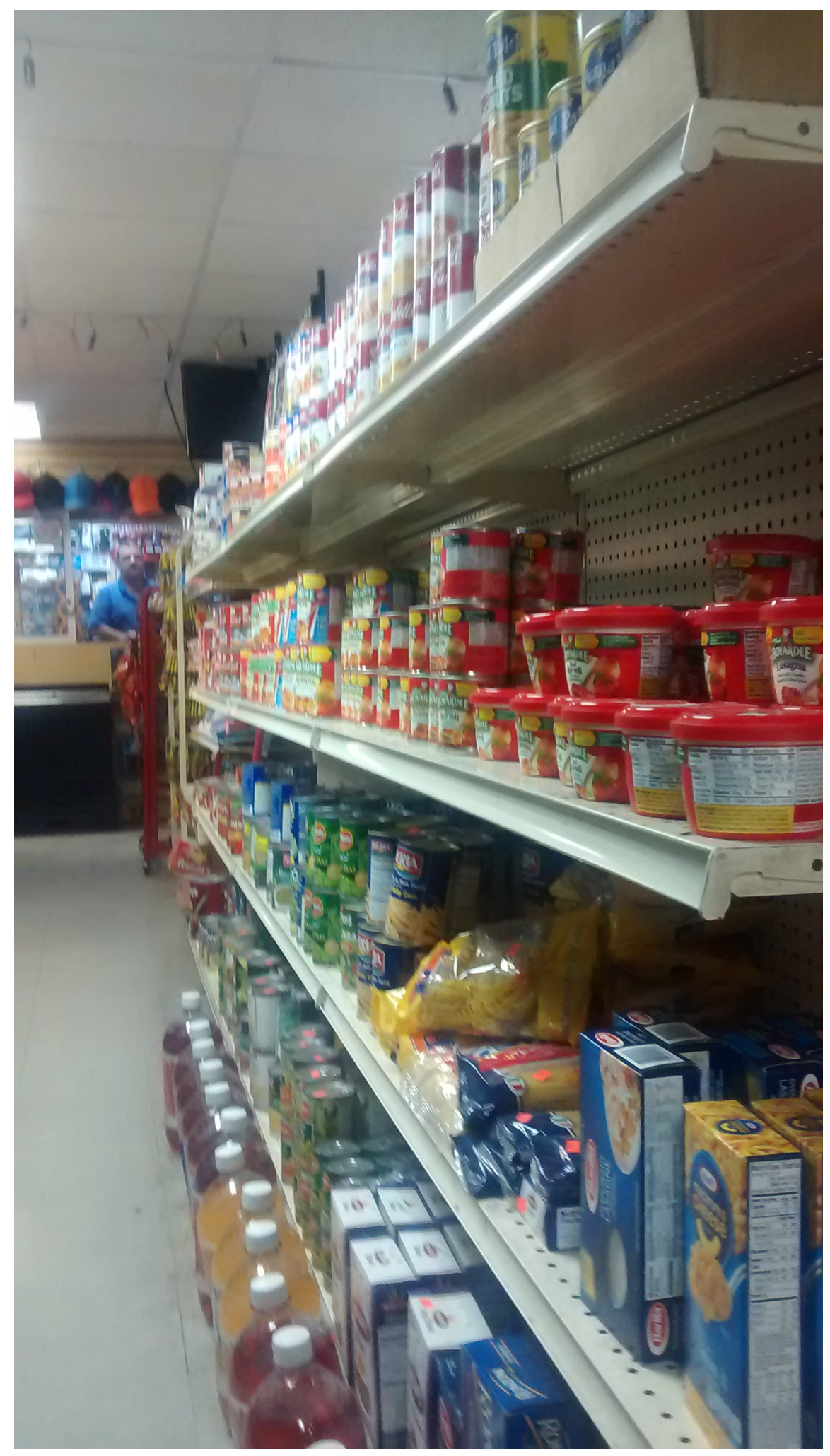

Figure 6.9: Canned, boxed, and bottled food and drinks on grocery shelves. 
Luis: Most of the time when I can help, I help anyone that come. A lot of people, you know, hard situation sometime. If I can help them, I help them, whatever they need. So a lot of them know, and so they come and some of them try to take advantage (laughs).

Author: They don't pay back...

Luis: No, no, no. Usually I give it to you, you don't have to pay me back. That way...

Author: That way you don't have to worry about it.

Luis: I don't have to worry about it and it doesn't become a revolving door. [...] But you can trust a lot of people. There's only a few that [...] sometimes they wanna take advantage. ${ }^{102}$

Over the years, Luis has also educated himself on how to prepare the foods he

sells, so that he can pass this knowledge on to younger residents who wish to cook foods

their deceased relatives once made.

Luis: Most of the people know each other way back. I have here the grandma, the daughter, the grandkid. Lately in the past five to seven years, we have lost a lot of old people, so that's why we're getting the daughter, the grandkid coming and buying the same item that the grandma usually comes [in to buy]. Some of them will ask me how they will cook some certain things, which I don't really (laughs), don't know it but... (laughs).

Author: You mean you know that they wanna buy it, but you don't necessarily know how to prepare it?

Luis: Yeah. So lately I've been getting a little more involved in how to prepare certain things. Uh, most of the time its like how you cook... that's the thing like if the collard greens, lima beans, uh, the bones... Also, what do they put when they cook oxtail? What [how] do they cook when they cook neckbone? All these things. I mean a lot of them, you know, they young people. They look at the mom or at the grandma, but they never pay attention to it, so now they have to do it.

Author: That's really interesting. So have you learned how to prepare some of these meals? Have you actually gone home and made them?

\footnotetext{
${ }^{102}$ Luis, interviewed by author, 18 March 2015, Overtown grocery store, Miami, FL.
} 
Luis: Yeah, yes, yes! We, we have cook a lot of them.

Author: Oh wow, that's kind of amazing. So what's the most recent thing that you learned how to make?

Luis: Oh, um... we try to do, what's the, um, ... pie. Um, sweet potato pie. Usually we don't cook sweet potato pie. So we try to make the pie because I was getting some shells and they were coming back and saying these shells not holding up. So what I did, I went and see which of the shell they need so they could hold up. So I went home and bought two or three different type of shell and, um, we got a... I've now I got the right shell.

Author: So it sounds like part of your job is to understand what the community needs, but then sort of be able to understand their cultural preferences.

Luis: Preference, yeah. Like I said, it's a lot of young kids. So how they, they haven't passed through them how to cook it. They seen it, they be eating it for the rest of their life. They wanna cook it. It's part of the tradition so they wanna do it. ${ }^{103}$

Luis thus serves as a community resource for the intergenerational transfer of cultural food practices. Others in Overtown described their food practices as passed down from earlier generations. When I spoke with an Afro-Guatemalan mother and daughter inside the recently opened Top Value supermarket, the daughter listed foods she likes to prepare for her family: "Rice, fish, beans, a lot of soup, a lot of stews, also tacos, enchiladas. A lot of tortillas, you know, a lot of breads, a lot of rices, a lot of beans. That's what she [her mother] cooks, and that's what I make for my baby now."104

Luis's store is also the chief supplier of meats for Jackson Soul Food. When I asked Alonzie who the restaurants suppliers were, he responded:

Definitely the markets, like the meat market. We keep everything in the neighborhood. I mean we go out to the meat store over there [Luis's store]

\footnotetext{
${ }^{103}$ Luis, interview by author, 18 March 2015, Overtown grocery store, Miami, FL.

${ }^{104}$ Jeanelle, interview by author, 5 October 2016, Top Value Supermarket, Miami, FL.
} 
and all that. I mean you basically pay almost the same thing. He might be a couple cents more. But we'd rather go there and keep the business here. Keep it circulating in the neighborhood. That's just how we think. Mostly all our meats, like turkey wings, everything we get from him. I mean, we even know where he get it from, but we don't even really care about that. We just rather do business with him and we been doing business with him so long, so we wanna keep that good relationship. ${ }^{105}$

However, despite Luis's longstanding embeddedness in the community, his tenure is uncertain. He does not own the property on which his business rests, and with property values rapidly appreciating, he may soon be forced to leave his location if the property sells. Luis has had to relocate once before and is concerned his store stands in the path of redevelopment, he tells me, pointing to an empty lot next door that was recently cleared. He also anticipates that residents will soon be displaced and is considering transitioning his business into a 7-11 to cater to an incoming demographic more accustomed to the aesthetics of a franchise operation.

Yet, while the CRA is purportedly committed to supporting small business in Overtown, none of the small groceries in the area have ever received financial assistance for relocation, renovation, or expansion. Etta Thomas interpreted the CRA's lack of interest in their grocery as part of the culture of individualism that has been cultivated in Miami. "You know what it take to do to help me get that [success]," said one longtime Black grocer who owns her property, "and instead of you helping me, you trying to destroy me, you understand? You know, we all god's children, regardless what color we are and everything, but you got some ideas that you got where you is and wanted to share

\footnotetext{
${ }^{105}$ Alonzie, interview by author, 30 July 2015, Jackson Soul Food restaurant, Miami, FL.
} 
with me, but you won't do that. ${ }^{\text {"106 }}$ Still, how do we explain the CRA's generous support for restaurant owners? Others suspect that, because their businesses cater almost exclusively to the current residents of Overtown, they do not fit within the CRA's future vision of Overtown's redevelopment.

Recall from chapter one Keon Hardemon's address during the groundbreaking ceremony of the Overtown Shopping Plaza:

This project is especially significant because it addresses Overtown's food desert, a complete depletion of affordable grocery stores. In this region, the closest store to a grocer is a convenience store and their merchandise is overpriced, which is unacceptable considering this community's average income. The fact that we're able to renovate this plaza and bring in a commercial business that specializes in food distribution is a tremendous success for Overtown. Residents won't have to shop for groceries at convenience stores.

In his speech, Hardemon implies that neighborhood groceries are price gougers taking advantage of poor residents.

To be fair, prices at Overtown's neighborhood groceries are generally higher than those at larger food retailers. During one corner store visit, Larry, an older longtime Overtown resident, picked up a bottle of Clorox, showed me the price $(\$ 5.00)$, and said, "What's five dollars here is $\$ 1.99$ somewhere else," meaning somewhere outside the neighborhood. "You used to have everything right here. You didn't have to leave to get things. Now if you want to get stuff, you got to leave." ${ }^{107}$ Larry tells me he likes to cook, often making dishes with oxtail, pork, fish, and "all kinds of beans." Because he feels the neighborhood stores are too expensive, limited in selection, and lacking in quality, he

\footnotetext{
${ }^{106}$ Etta Thomas, interview by author, 17 August 2016, Overtown grocery, Miami, FL.

${ }^{107}$ Larry, interview by author, 4 November 2014, Overtown grocery, Miami, FL.
} 
shops once a month at Northside Meat Market about six miles northwest of Overtown. There "the food is good, and the price is reasonable." Larry is also looking forward to the opening of a Walmart in Midtown (currently held up in controversy between city officials, business owners, and area residents) because they have a large selection and affordable prices. Darita, the Afro-Guatemalan resident I met in the supermarket said, "Me personally I like to go to the supermarket because they have a very good special shelf, just like that one right there, so we can accommodate our food. [...] we go to Winn Dixie, Publix, those two places." 108

Some other residents I spoke with also expressed dissatisfaction with the pricing, availability, and quality of grocery items in neighborhood stores. Shortly after speaking to Larry, I met Rhonda, a middle-aged African American woman who grew up in Overtown. She stated that prefers taking the bus or getting a ride to Winn-Dixie while her children like to walk to Publix. In addition to finding prices at the neighborhood stores to be too high, she described the perishable food as questionable: "A friend of mine brought me some meat from [a neighborhood store] about a year ago, and it didn't look right. It looked too dark like it had been dyed red to look fresh. I just refused to cook it, and I don't go there." ${ }^{109}$ Rhonda tells me she learned to distinguish the quality of meat through her experience working as cook for the doctors and staff at a local hospital. She therefore buys her meat outside of Overtown, at one of two markets north of the neighborhood.

Rhonda and Larry's comments corroborate findings from a 2007 assessment of business in Miami's inner city neighborhoods, where 93 percent of Overtown residents

\footnotetext{
${ }^{108}$ Darita, interview by author, 5 October 2016, Top Value Supermarket, Miami, FL.

${ }^{109}$ Rhonda, interview by author, 4 November 2014, Overtown grocery, Miami, FL.
} 
reported a need for more full-service grocery stores, and 70 percent purchased grocery items outside the community (Social Compact 2007). Almost all of the residents I spoke with who make larger shopping trips do so at supermarkets outside the neighborhood, most often at a Winn Dixie located eight blocks west of Overtown's center or at a Walmart five miles northwest of it. Both are accessible by bus - "it's a straight shot on the 41 ," said one resident during an informal conversation at a bus stop - and it is common to see residents returning from trips with portable push carts stocked with bags (see Figure 6.10).

However, larger retailers, such as Walmart and Winn Dixie, are only able to keep prices relatively low because they capitalize on economies of scale to drive large volumes of sales, even if at small profit margins (Tedlow 1990). Small grocers, on the other hand, must constantly tweak their minimal stock to maximize sales and profits. This can be particularly difficult because store space is small, and the profit margins on most goods are very low-and shrinking. As one Middle-Eastern grocery owner, Johnny, explained to me: "I'm being here twenty five years. So this used to be like (pointing to a snack), you [the owner] buy it for fifty cents, you sell it [to the customer] a dollar. But if you buy a hundred case of these, you take it for quarter, so I could sell two for dollar. So I'm still making good money. I could invest. But not anymore." ${ }^{\prime 10}$ Johnny then discussed the challenge of mediating rising food costs with customer expectations. Showing me a bag of chips with a factory label that read, " $2 / \$ 1,59 \notin$ ea." he explained:

Now, he [a customer] come, he buy one chip. He never pay fifty-nine. He don't wanna pay fifty-nine. He just drop fifty cent, throw me the fifty cent.

\footnotetext{
${ }^{110}$ Johnny, interviewed by author, 4 August 2015, Overtown grocery, Miami, FL.
} 


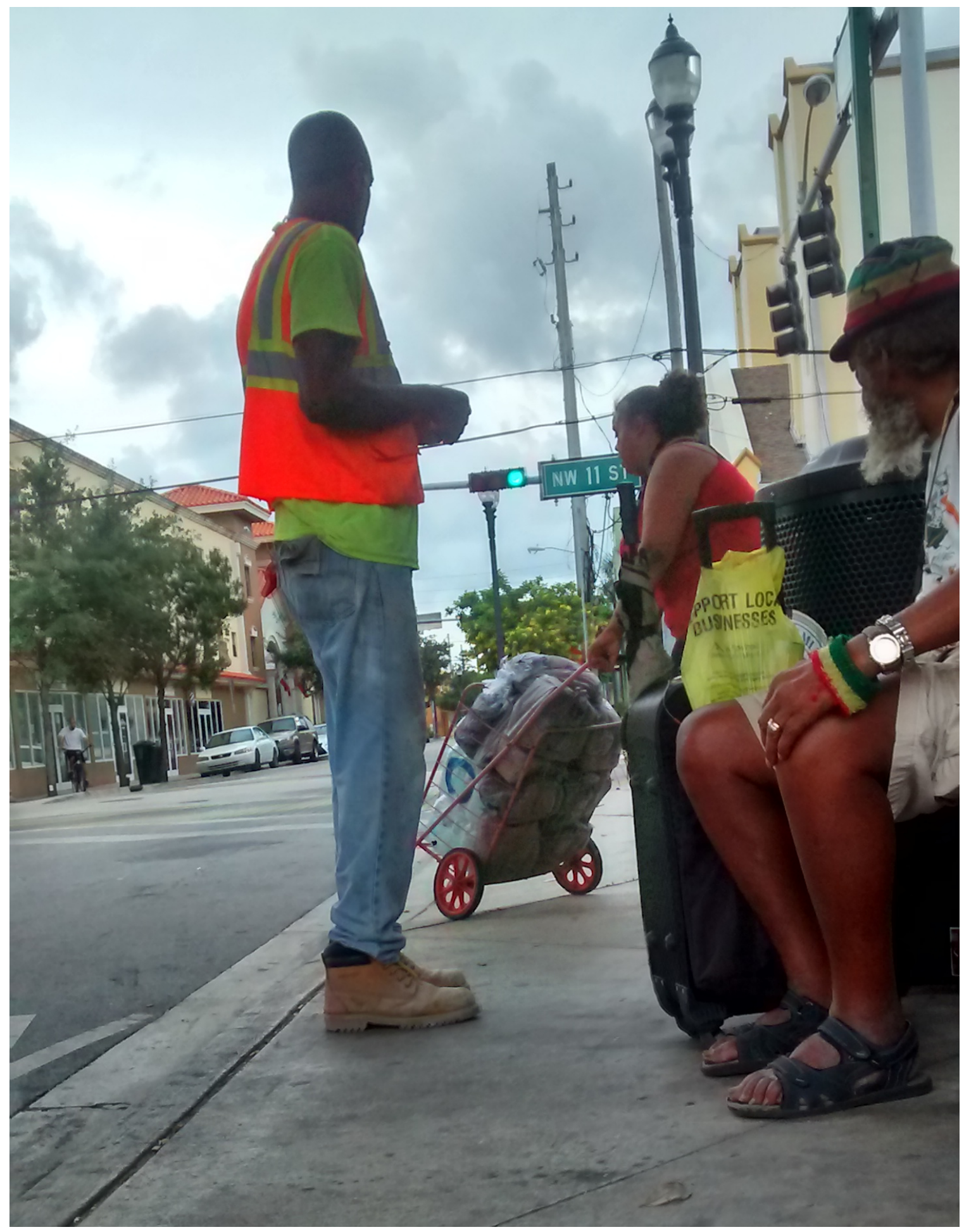

Figure 6.10: A resident returning from a bus trip to Walmart pushing her groceries. Photo by author. 
So now you nine cents down. You lose it. They don't get two [bags]. They get one chips. And they get one soda for fifty cents, that's \$1.09. But they give you a dollar. Especially when they come to the stores, with the kids, they have a dollar in his hand. Especially the kids. You're not gonna turn 'em away for nine cents. It just makes no sense. Nobody pay this price (pointing to the price included on the factory label). The company go up with the price because they put the nine cent. But me, I cannot go up because I lost my profit [sale]. So that's why my profit go down from thirty-two, thirty-five [percent] to twenty-five or less. ${ }^{111}$

In the last decade, business has also suffered from an increased police presence in the area. Added Johnny,

Three months ago the police shot somebody, the homeless guy. That was shut down to the whole area, from the street here all the way down, nobody walking, nobody out. I'm sitting the whole day here. I'm barely fucked already. There is no business. And you do stuff like that? Forget it. Your rent is still the same, your electric the same, your employees the same, you don't make enough money, you have to pay your bills. I cannot pay my bills. I barely pay my employees. So I'm done. Whatever I save is gone. So what I'm doing now, I'm waiting till they bring more people here or I close the store and go. ${ }^{12}$

While none of the residents I interviewed explicitly stated that the police presence

inhibited them from visiting a neighborhood grocery, two residents I spoke with in a

barber shop, both younger Black men, spoke about heavy-handed policing in the area.

Jerry: They job is to protect and serve, but they do it sideways. It's who they wanna protect and who they wanna serve.... I be catching what's goin on. [Shows me a picture on his phone of an unmarked police car.] That's one of the cars that come by like, they be like, 'Oh, pussy ass nigga.' [...] It's misjudgment. Like, what you see when you see me? You see a thug, right? Be real, you see a gangsta? ... Don't get me wrong. It's good to have police. But at the same time, we don't need a motherfucker putting they feet on our throats, especially when a nigga's just trying to like make a living."

\footnotetext{
${ }^{111}$ Johnny, interviewed by author, 4 August 2015, Overtown grocery, Miami, FL.

112 Johnny, interviewed by author, 4 August 2015, Overtown grocery, Miami, FL.
} 
Darrelle: "I just feel like they need to stop the gang that's in the police system, right, you feel me? The police is just a gang like, you have like eight police that have guns that surround, that work in Overtown. That's a gang. That's eight people in a gang. It ain't no squad or, you feel me? It ain't no police force. It's a gang that's going against the community. That's all it is. Then it's not only that like it's a gang, like, they talk what they gon' do when they go back to work. They talkin' bout what they f'nna go do."

Jerry: "Billy, all you gotta do is stand on the corner with your bookbag on, and keep your water bottle in your hand. I'll bet they say something to you. They might say, 'Get off this corner.' They don't wanna see you when they come back around. Something like that. Like I even stand outside, smokin' a little Black and Mild or something. They done rolled by and told me to get off the corner. Not even knowin' that I own the business [on the corner where he is standing]. [They] Tell me, "you need to get off the corner." Most police around here, man, they'll just write you up a charge and say, "Fuck it. You deal with it." Trespass, loitering, resisting arrest without violence. They take you to jail. Then if you're like, "Whatever I did wrong, I'm sorry." They be like, "Oh, it ain't my problem. I'm going home and you going to jail." That's how they deal with the situation. ${ }^{113}$

At the same time that some residents feel intimidated by police tactics, the CRA

has continued to double down on financing extra policing in Overtown. Since 2008, the

CRA has invested nearly $\$ 3$ million on pilot police programs that create an enhanced

police unit to supplement existing patrol officers. During a CRA board meeting, current

District 5 commissioner and SEOPW CRA chairman, Keon Hardemon, stated:

The presence of police officers, I think, personally, is important to invite business, to invite development. Within our Redevelopment Plan and within the Redevelopment Act, it talks about how crime is a deterrent to redevelopment. And so just tackling the issues of crime, the perceived -or the perception of the safety of a neighborhood, in order for this community to move forward in a positive way, and for people to feel safe walking our community, and coming there in the evenings to enjoy themselves at fancy restaurants, and see plays, and visit our -- frequent our Lyric Theater, there has to be the perception of safety. And I think that our boys and women in blue give us that. (City of Miami 2015, 43).

\footnotetext{
${ }^{113}$ Jerry and Darrelle, interview by author, 9 June 2015, Overtown barber shop, Miami, FL.
} 
Lastly, the City of Miami, through its Overtown Neighborhood Enhancement Team (NET), has become increasingly active in sanitizing and securitizing areas of Overtown surrounding the more revitalized retail and entertainment corridors. In addition to providing a range of city and social services, such as fixing streetlights and potholes, removing dead trees, assigning permits for events, and assisting with tax preparation, the NET's responsibility, according to one city official, is to "make sure [the CRA's] investment is protected by making sure the area is clean, working with the police department to make sure the area's safe." 114 As part of the effort to "clean up the streets," the NET seizes shopping carts from the homeless, makes sure buildings are up to code, and shuts down illegal business activities in the area, including the preparation and selling of foods from homes or on the streets without a permit or license. During my fieldwork, the NET office shut down a weekly "pop-up restaurant" that sold fish, grits, and drinks. Said Ray: "Yeah, there used to be a fish fry. They start at night. You know that store you were talkin' bout? They used to do it 'cross the street from there. There be lines of people." ${ }^{115}$ In the summer of 2016, Ray was told to leave his rooming house because the building was in violation of code. These practices, of course, are common in most neighborhoods, but the question is, why are they suddenly happening now after decades of disinterest?

\footnotetext{
${ }^{114}$ Alyssa, interview by author, 9 January 2015, Overtown social services office, Miami, FL.

${ }^{115}$ Ray, interview by author, 5 June 2015, Overtown park, Miami, FL.
} 


\section{Unmaking the Food Desert}

Overtown has been labeled a food desert, but we're going to have a supermarket here. This will certainly alleviate that food desert distinction.

- Clarence Woods III, SEOPW CRA Executive Director

In October 2016, the CRA hosted a grand opening event for regional supermarket chain, Top Value, the anchor store of the Overtown Shopping Plaza and Overtown's first supermarket in more than a decade (see Figure 6.11). Having undergone \$2.2 million in renovations, the shopping plaza played a significant role in the CRA's plans to revitalize Overtown's commercial environment. Recall from chapter one when city commissioner and CRA board member Francis Suarez stated: "I think one of the things that in my travels through Overtown that's been glaringly missing, that is in every other community, ... regardless of socio-economic background, regardless of ethnicity, et cetera, is a shopping center."

Under normal market conditions, it is unlikely that Top Value would have opened a store in Overtown. According to one city official,

this particular business [Top Value] looked at coming into this area several years ago, before it was rehabbed the way that it was, before, you know, people weren't scared to walk down Third Avenue, they wanted to come here. And it just wasn't a good investment at that time, just because it wasn't, ... this complex looked a lot different. It was a location that was housing a lot of homeless residents and it just needed a facelift. So this guy had been in the negotiations with the city for forever and the CRA for forever. The CRA decided [...] this needs to be the first place that we rehab when we're going into this new administration with Mr. Hardemon. We need to look at taking care of home first. So now with it being rehabbed and everything and people - it's brighter, it's more vibrant, it's active. Now the grocery store is like, "Yeah, you know this is the time for us to come in, and because we believed in you from twenty years ago. ${ }^{116}$

\footnotetext{
${ }^{116}$ Alyssa, interview by author, 9 January 2015, Overtown social services office, Miami, FL.
} 


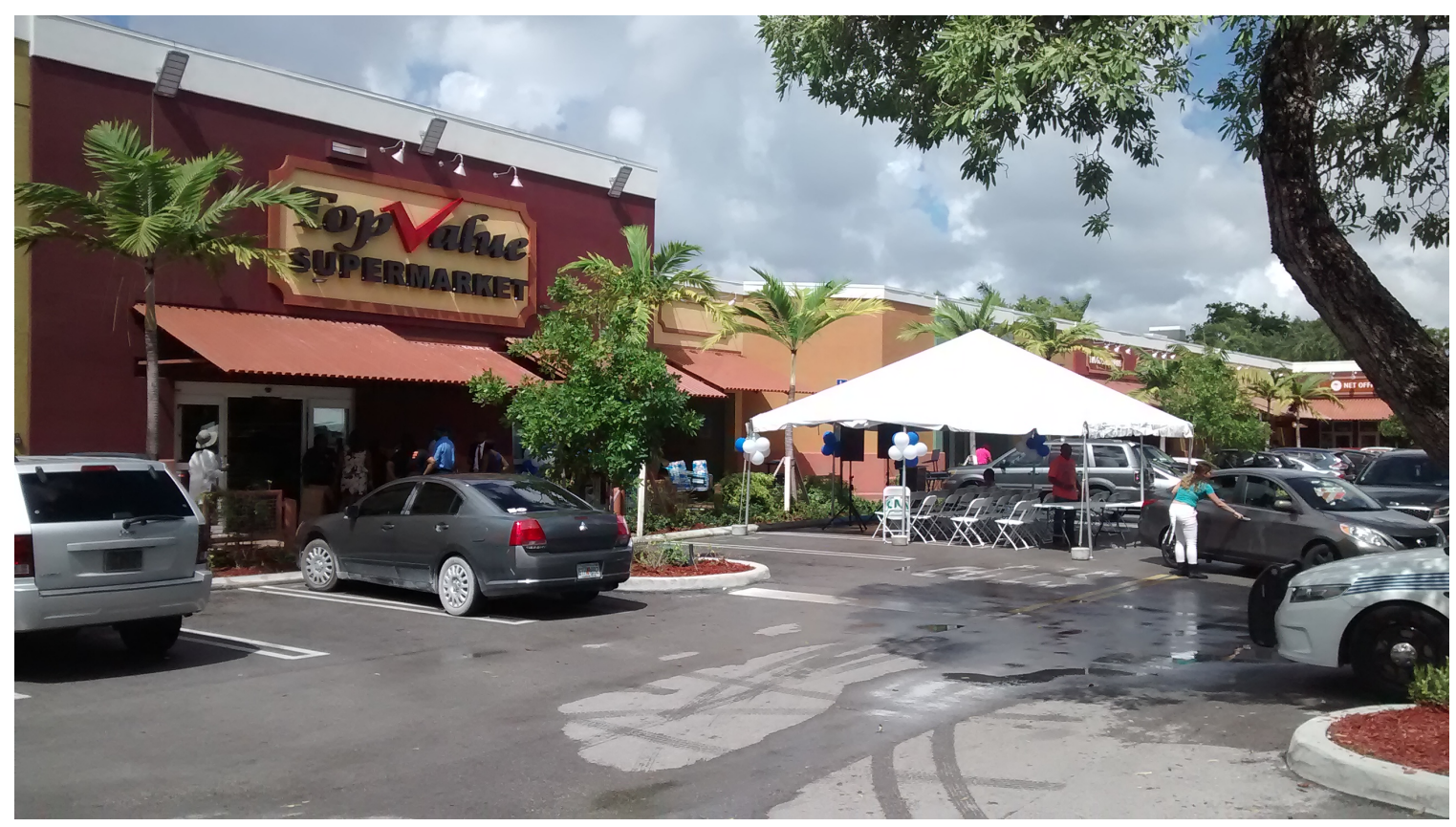

Figure 6.11: The Top Value supermarket and Overtown Shopping Plaza. Photo by author.

After four years of negotiation, the CRA agreed to incentivize Top Value with a $\$ 200,000$ grant and a $\$ 400,000$, in addition to the complete overhaul of the plaza itself.

Independent chains like Top Value often seek out lower-income neighborhoods and neighborhoods of color on the rise because corporate stores have yet to move in, they can outcompete smaller groceries on price and selection, and they see potential growth as the area develops and attracts more upwardly mobile residents. During a conversation with the owner and one of his vendors, the two explained how smaller grocery chains have a more flexible business model than corporate supermarkets, which allow them to respond to the needs of the community faster and more directly. As the vendor stated:

I'm sure if he [the owner] had 1,500 stores, his business model would be a little bit different. Like right now, right now if this product comes in today, and the company calls me and I can go down the price, I could lower it down like that. But for them [large supermarkets], to go down in price it would take, you know, corporate office and all that. Or if this brand doesn't sell, we replace it with a brand that the community wants. 
Or if it sells a lot, we'll buy a lot more and open up shelf space, whereas in the big supermarket, everything is allocated according to a corporate footprint. And it almost has to be that way because if you're managing Walmart, eight or nine thousand stores, could you imagine if every manager had autonomy to buy from whomever and lay out the stores as they wished? It's not possible. That's where the independents [supermarkets] come in and they really have the ability to do a lot of that. You came here. You didn't have an appointment. You talked to him [the owner]. If you went to Publix up in Lakeland - and Publix is a great company. If you were to go to Lakeland, you'd never have access to anyone in top management. So that's the difference between a small entrepreneur and a big corporate giant. ${ }^{117}$

In other words, independent supermarkets operate much the same way as the smaller convenience groceries in that the stores are easily adapted to suit customer preferences, even though the store size is much larger. Said the owner: "If somebody asks for a particular product, I can probably have it in the store by tomorrow." When I asked a store manager why they were interested in opening a store at this point in time, he pointed across the street to the building housing Luis's meat and grocery store and said, "It's a great time to be here. You see this? In two years, they're going to tear all of this down," indicating that the supermarket will benefit from the many redevelopment projects sweeping across Overtown.

The arrival of the Latino-owned supermarket ended a twelve-year stretch during which Overtown residents had to leave their neighborhood to shop at a full-service grocery. On the day of the opening, one CRA official stated to me:

This store is symbolic in the sense that Overtown been a low-income, historically neglected community, was considered by definition a food desert. And a food desert is an area, a mainly impoverished or low-income area, where the residents don't have access to quality food at a reasonable price. You know, certain African American or Hispanic or low-income areas, they have the corner stores, but they don't have supermarkets or

\footnotetext{
${ }^{117}$ Tony, interview by author, 5 October 2015, Top Value supermarket, Miami, FL.
} 
superstores. And so, that's why this opening is so significant, 'cause it eliminates Overtown as being a food desert. ${ }^{118}$

During the grand opening event, the City of Miami tweeted "\#fooddesert? Not here!" (see Figure 6.12). A few days later, the Miami Times, Miami’s oldest and most widely read Black newspaper, published an article titled "Overtown, food desert no more" (Guniss 2016).

Every resident I spoke with personally responded positively to the store's opening. "Black people don't have stuff like this so it's a good thing," said one African American woman. ${ }^{119}$ Her comment, like Larry's (mentioned earlier) about having to leave Overtown to "get things," is reflective of how food environments are socially constructed and perceived in relation to racial and spatial boundaries. Prior to the opening of Top Value, Overtown actually had three supermarkets within a mile of its center, despite all of them being located in more affluent adjacent neighborhoods. Despite Overtown not meeting the USDA's (2009) criteria for a food desert, some residents view the proximal major food retailers in the area as not part of their community, even if they shop there. Another resident, Darien, a young man originally from Haiti, viewed Top Value as beneficial because "it's right around the corner, so you talkin' about less traveling. So you talkin' about saving money on groceries and gas." ${ }^{120}$ Jodie, a middle-aged woman from Jamaica said, “This area is developing. We need this. We don’t need one to go somewhere that one needs to be scared to walk around. We want to go along, do our

\footnotetext{
${ }^{118}$ Joe, interview by author, 5 October 2016, Top Value supermarket, Miami, FL.

${ }^{119}$ Patricia, interview by author, 5 October 2016, Top Value supermarket, Miami, FL.

${ }^{120}$ Darien, interview by author, 5 October 2016, Top Value supermarket, Miami, FL.
} 


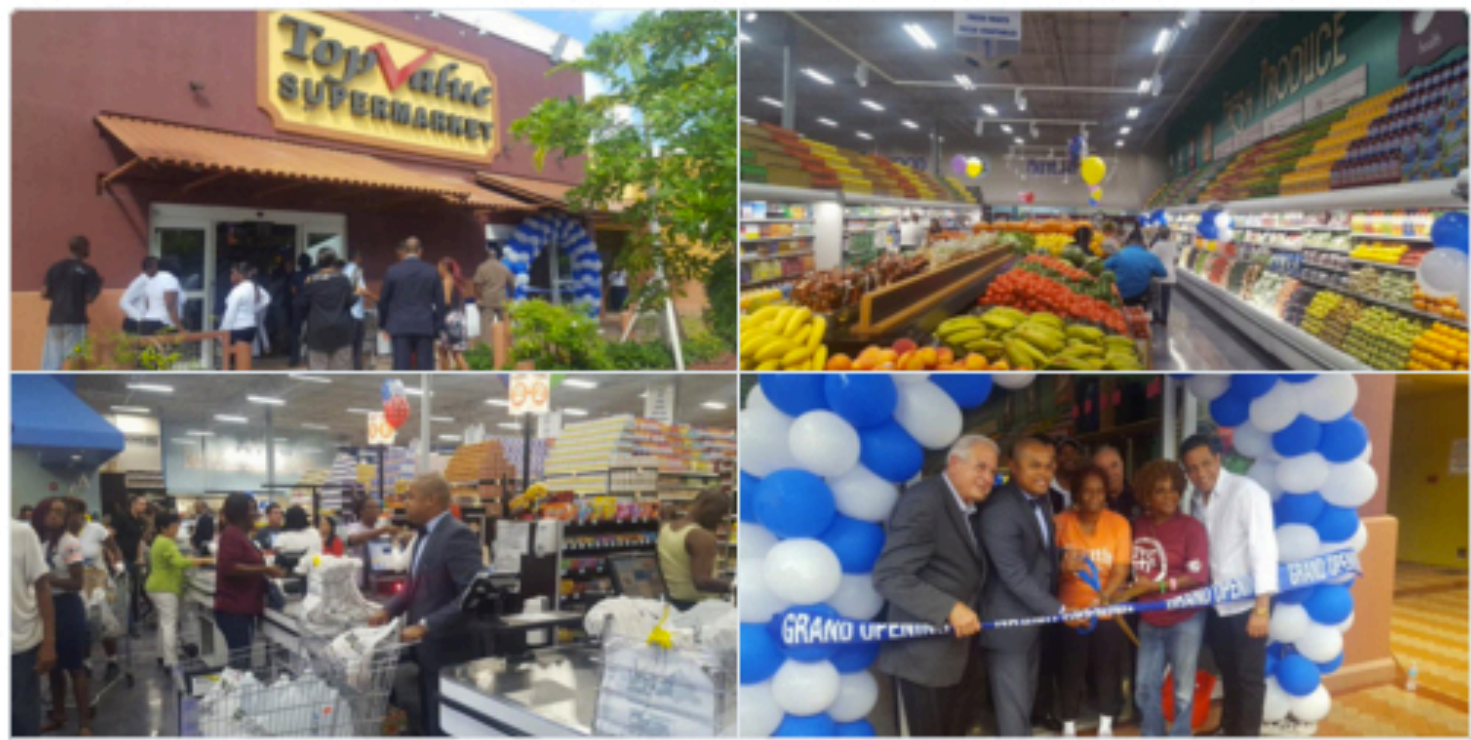

\section{(*2) City of Miami}

@CityofMiami

\section{Follow}

\#Overtown's first major grocery store is open for business!

\#fooddesert? Not here!\#freshproduce \#grandopening

11:38 AM - 5 Oct 2016 · Miami, FL, United States

\section{4 $2712 \bullet 20$}

Figure 6.12: A City of Miami tweet during the grand opening of Top Value supermarket.

shopping just like everybody else."121 Jodie views the supermarket as not only providing needed retail, but in doing so, making the neighborhood more walkable and safer.

However, not everyone in Overtown felt wholly positive about Top Value. In their coverage of the grand opening, the Miami Times quoted one resident stating, "Not hating on the other that put their money together to open that store but we as Black people got to get back to owning our own markets, stores and properties. Other races are

\footnotetext{
${ }^{121}$ Jodie, interview by author, 5 October 2016, Top Value supermarket, Miami, FL.
} 
continuing to profit off us" (Guniss 2016). This statement echoes long held concerns among Overtown residents about outsiders extracting wealth from the neighborhoods and Black communities more generally. Certainly Luis is concerned that Top Value, located directly across the street, will impact his business. During the grand opening, I visited him. "We'll see," he told me. "I'm still being here. The people will do what they gonna do." 122

As we see it referenced by the CRA, the food desert concept is not simply objective fact but is discursively deployed to further certain political economic interests, in this case to attract supermarkets and catalyze future investment. Although it has been helpful in calling attention to spatial disparities in the modern food delivery system, on the other hand, the popular metaphor too crudely constructs places, often low-income communities of color, as barren and lacking, joining with other pathologizing underdevelopment narratives while failing to recognize the policies and processes that create conditions of poverty. As Shannon writes, "The identification of certain neighborhoods as food deserts may ... identify the symptoms of a dysfunctional food system and patterns of economic and racial segregation, but do little to shed light on the more geographically expansive processes that cause them" $(2014,258)$. The food desert discourse enables the CRA to lump together existing actors in Overtown's food landscape and vilify them as price-gouging suppliers of low quality basic goods. Yet as I demonstrate, some small groceries have spent decades building relationships with the people they serve and in so doing are able to uniquely respond to community needs.

\footnotetext{
${ }^{122}$ Luis, informal conversation with author, 5 October 2015, Overtown grocery, Miami, FL.
} 


\section{Community Perspectives on Redevelopment}

Farid, an African American man of about thirty who grew up in Overtown, drives me around the neighborhood and tells me the "Spanish" (meaning Latin Americans) are the major investors in Miami these days and are fueling the latest round of gentrification.

“The Spanish are squeezing Blacks out to make room for what they wanna do." ${ }^{123} \mathrm{He}$ points to various spots along the way, describing recent changes related to his main point that Overtown is being rid of its poorer Black people. He shows me the strip of land running along I-395 that has been claimed by the FDOT, bulldozed, fenced in, and now awaiting the expressway's expansion. We drive by the construction of two "affordable" housing projects. We pass by his home, one of few single-family houses in the area. Farid owns his property and tells me he has been getting offers for it upwards of $\$ 200,000$, more than double its appraised value. Finally, we stop near the Metrorail station where a fenced off site advertises the development of Krystal Towers, a market rate condominium where one bedroom apartments start at $\$ 200,000$. The photos on the banner advertisement show young, light skinned people enjoying the pool, and Farid jokes about how the ad doesn't even pretend that Blacks will take part in this.

Earlier that day, I spoke with Frank, a longtime African American resident and Overtown business owner in his sixties. "They're all crooks," he tells me in his shop, then goes on to say that Black politicians like Keon Hardemon, who are not from Overtown, are being used as representatives of the community to fulfill the desires of wealthy

\footnotetext{
${ }^{123}$ Farid, interview with author, 9 January 2015, interviewee's car, Miami, FL.
} 
investors and developers. ${ }^{124}$ Other residents feel that Hardemon and the CRA are well meaning but misguided in their approach to community development. During an interview with Barbara, a longtime resident and community leader mentioned in chapter four, she described Hardemon as being an "employee," unable to recognize and effectively utilize the power he wields as the CRA chairman to ensure Overtown residents participate in the redevelopment process. She added:

The reason we have a CRA is this community is not dumb. We did this way back, starting in 1970. We finally got the CRA in 1982. [...] The whole redevelopment plan that is happening now, we might not be a part of it, but fifty percent of the equity in every one of these projects was supposed to go back to the minority community because we have been left out of the major developments in the City of Miami. [...] The sad part is that the commissioners from other districts do not carry out the plans that was happening prior to them arriving. And the people that they hire are people who are employees of government who have no commitment to communities. So it ain't we don't know, it's the fact that we've had a transition in the community. We have resolutions dating back to 1979 on how it should happen. ${ }^{125}$

Similarly, a master contractor named Ted informed me that Hardemon had very little understanding of the development process and how to make sure that the Overtown community could stake a future in it. I met Ted at an Overtown groundbreaking event for Atlantic Pacific's mid-rise Island Living housing project. As mentioned earlier, the CRA receives tens of millions of dollars in TIF funds each year, has become Overtown's largest landholder, and is therefore in a position to call many of the shots regarding how development takes shape. Referring to the deal with Atlantic Pacific, he stated with a

\footnotetext{
${ }^{124}$ Frank, interview with author, 9 January 2015, interviewee's business, Miami, FL.

${ }^{125}$ Barbara, interview with author, 5 June 2015, Overtown social services center, Miami, FL.
} 
saddened and disgusted face, "They [the CRA] had the land, and they gave it away." 126 From his perspective, Hardemon failed to ensure that Black contractors, electricians, plumbers, and construction workers would work on the project, instead letting Atlantic Pacific dole out the jobs. He later described the CRA and Hardemon as akin to the western Africans who recruited slaves from the African interior for the colonizers.

"It's bad, man," said Jean, an Overtown resident I met earlier in my fieldwork. Jean tells me the CRA's main method of getting land is coercing property owners to sell it to them cheaply, usually by harassing them or getting the city to investigate those who do not accept deals. He adds that in Overtown it is easy for people to become corrupted because the community doesn't have the "talent" to stand up to politicians and demand a fair price.

In addition to allegedly harassing property owners to give up their land (so that they can then move it into the hands of developers), the CRA routinely makes large-scale deals made behind closed doors and then pushes them through public CRA board meetings. To give an example, the CRA scheduled a board meeting in 2014 in the interval between Christmas and New Year's Eve to discuss the $\$ 100$ million economic incentive agreement for Worldcenter among other items. Frank Schnidman, a retired Florida Atlantic University professor of urban and regional planning, commented on this board meeting during a Social Justice Table meeting organized by Catalyst Miami: ... in absolute disrespect to the residents of Overtown, the meeting between Christmas and New Year's had twelve items on the agenda. The twelfth was Worldcenter. The first eleven, which included the million dollars to a restaurant and $\$ 1.2$ million to a supper club, had almost

\footnotetext{
${ }^{126}$ Ted, interview with author, 9 January 2015, Overtown restaurant, Miami, FL.
} 
nothing in the agenda package to explain what they were about. All eleven were ganged together including other grants and rushed through. No presentation by staff. No presentation by the applicant, and approved. Worldcenter came up. People testified about it because they wanted the CRA to approve it. The CRA wasn't approving it. [...] The CRA has no regulatory authority, and so it was the city that approved the project. It had already been approved [before the meeting]. [...] It was only this economic incentive agreement, which really they [the CRA] had no authority to do it. ${ }^{127}$ And so what happened very simply between Christmas and New Year's was the CRA approving what commissioner Sarnoff clearly stated was a reward for the developer for building this project. $^{128}$

Yet, as Schnidman describes, there are a fair amount of residents who have hope that Worldcenter and other economic development initiatives spurred by the CRA will rescue Overtown from poverty. After decades of public disinvestment and broken promises, many see the neighborhood's improved parks, cleaner streets, new and renovated buildings, and successful businesses as a welcome change. Said Candice, a younger African American woman I met and interviewed at an Overtown bus stop, "I like seeing the people cleaning the streets and seeing the buildings get built. I think it's good. I don't like seeing these old buildings and the trash. They [landlords] don't check on the water, the wires, and the people here are used to it so they don't mind. But I'm trying to see a nigga get a view. I don't really like Overtown. I just stay here 'cause the rent is cheap." ${ }^{129}$ Candice's emphasis of the word view suggests a double meaning: one, referring to a literal view, perhaps from the vantage point of a higher level condominium floor, and two, a view of life beyond the streets of Overtown.

\footnotetext{
${ }^{127}$ Schnidman believes, following the opinion of the Attorney General of the State of Florida, that the CRA does not have the legal authority to finance tourism and economic development, as their chief goal should be to address matters of affordable housing and the elimination of slum and blight.

${ }^{128}$ Frank Schnidman, 13 March 2015, Catalyst Miami Social Justice Table, Grand Central, Miami, FL.

${ }^{129}$ Candice, interview with author, 12 March 2015, Overtown bus stop, Miami, FL.
} 
In some cases, people in the community have even internalized the racialized neoliberal rhetoric used to explain Black poverty, believing that Blacks are not hardworking, that they just want government handouts, and that they lack good social behaviors. "When I wake up," said Candice, "I go to work and people just be standing around outside. When I get home, they still standing there. These old people, they don't wanna find a job." I asked if she thought they were just unwilling or that they didn't have opportunities. "No, I don't think they didn't have opportunities. I been at my job six months and I was a supervisor after two months. I'm Black and I'm trying to get a view. I hate to say it, but we need to see more white people, more Hispanic people here." ${ }^{\prime 130}$ Ray, overhearing her speak, commented, "She right. Look, I'm disabled, I had a stroke, but she right, though." ${ }^{131}$

Still others hold defeatist views, either feeling too absorbed by the daily struggle of survival or feeling as if nothing they can do will amount to any change. Ray once told me, “Look, I'm living to-day. I don't know what's goin' on tomorrow-I might be dead. I'm living right now. I don't know if I'm gonna wake up tomorrow. I don't know if I'm gonna wake up tomorrow. I don't know if I'm gonna wake up tomorrow. 'Cause anything could happen." ${ }^{132}$

\footnotetext{
${ }^{130}$ Candice, interview with author, 12 March 2015, Overtown bus stop, Miami, FL.

${ }^{131}$ Ray, interview with author, 12 March 2015, Overtown bus stop, Miami, FL.

${ }^{132}$ Ray, interview with author, 12 March 2015, Overtown bus stop, Miami, FL.
} 


\section{Whither Overtown?}

Earlier research on gentrification and urban revitalization viewed it as a gradual process involving the interplay between investors interested in exploiting rent gaps (Smith 1979; 1987) and the sociocultural investments and demands of the "new middle class" (Ley 1994). Hackworth and Smith (2001) identify another form of gentrification, which began to emerge in the US in the 1990s. Here municipal governments collaborate with private (often corporate) developers and investors to orchestrate the process of revitalization. Likewise in Overtown, gentrification is led by a strong partnership between local government and developers, business owners, and property owners, with the CRA playing a central role in mediating this relationship. Specifically, the CRA appropriates tens of millions of dollars in public funds each year to subsidize developerled projects that include "affordable housing" construction, luxury condos, commercial plazas, mega retail and hospitality projects like Miami World Center, and, of course, the creation of the Folklife Village. In many cases, the CRA also acquires vacant and neglected properties and provides them cheaply to developers.

Still, even while public-private partnerships and TIF have emerged as key facets of urban revitalization, gentrification is not a one-size-fits-all process. The way gentrification happens depends on the existing neighborhood's assets, social structure, and relation to a broader political economy. In Miami, the CRA ultimately wants to stretch the boundaries of Miami's real estate and tourism-based economy across the historical racial barrier of the train tracks and into the frontier of economically distressed Overtown. To make Overtown the kind of place that can lure mobile capital, the city has cherry picked elements from Overtown's cultural history and reimagined its future as a 
cultural dining and entertainment district. In the current gastronomic moment, where celebrity chefs and discerning foodies have suddenly "discovered" bacon, fried chicken, collard greens, shrimp and grits, and so on, African American food is part of the material and cultural fodder being used to transform Overtown from a working-class neighborhood into a space of consumption for tourists and the middle-class, similar to what has taken place in Harlem and Bronzeville (Hyra 2008). In tandem with new housing developments, aesthetic improvements, and the "arbitrary enforcement of [...] land-use rules and building codes in the interest of neighborhood upgrading and gentrification and/or production of local 'hot spots"' (Sutton 2015, 201), the creation of hospitality and retail corridors is part of a municipal plan to smoothen the visual transition between Overtown and its more prosperous surroundings and expand the spatial possibilities for capital investment.

Food and food spaces are important to this geographic process because they play a role in maintaining the ordered class and racial hierarchies required of profitable spaces of consumption. Food is deeply embedded within the symbolic world of meaning making and entangled in a web of racial, ethnic, classed, and gendered associations (Witt 1999; Williams-Forson 2006). Visual and other sensory flows of food production and consumption signify who and how one is (not) shopping, (not) eating, (not) cooking, and (not) cleaning. In creating Overtown's Folklife Village, the city aims to organize classed and racialized bodies in place, creating zones in which clearly defined social roles typical of consumptive spaces will unfold, e.g. owners, cooks, servers, performers, viewers, tourists, eaters, drinkers, and so on. This culturally consumptive experience builds upon a long legacy of tourism in Miami, in which brown bodies provide the service and labor for 
lighter-skinned consumers. According to Shell-Weiss, “Keeping Miami’s façade aglow required not just marketing, but regular scrubbing and polishing. Yet these jobs paid little more than a pittance, leaving almost half of Miami's people - and especially women - of color "cleaning and caring in the shadows of affluence"" $(2009,236)$. In other words, the redevelopment of Overtown into a dining destination is a "racial project" (Omi and Winant 1994) in that it "classif[ies] and assign[s] social and political meaning to difference, thus allocating goods, services and resources accordingly" (Brahinsky, Sasser, and Minkoff-Zern 2014, 1139).

Meanwhile, as outside private developers and Overtown's propertied business class are publicly subsidized and invited to claim a longtime stake in the neighborhood's future, small businesses and residents (ninety percent of whom are renters) are left susceptible to the whims of the market as the rent gap continues to widen, a recipe for displacement. Just as Stacey Sutton found in Central Brooklyn, in Overtown, "concerns about city policies and survival are more often articulated by pre-gentrification retailers," whom "are more likely to be ethnic and racial minorities" (Ibid., 201). The CRA's generous grants to restaurant owners, incentives to the Top Value supermarket, and disinterest in existing small groceries provides evidence as to which actors are envisioned to participate in the project of community redevelopment as well as those viewed as "out of place" and undesirable. Ultimately, the line of inclusion is drawn around those businesses that can provide services and goods to more upwardly mobile consumers. Those businesses, such as Luis's meat market and other small groceries, whose predominant clienteles are existing neighborhood residents are seen as untenable in the long run, despite their longtime presence. I therefore argue that redevelopment practices 
in Overtown are not only aimed at attracting tourists and affluent outsiders, but are also eroding existing relationships of social and economic interdependency that have sustained Black life through decades of public neglect. In similar fashion to 1960s urban renewal, community redevelopment is beginning to displace and dispossess people in Overtown and threatens to erase a "black sense of place" (McKittrick 2011). 


\section{CONCLUSION}

In this dissertation, I have examined the social and historical forces that have given rise to food deserts and the development of a cultural dining destination in Miami's poorest neighborhood, Overtown. I first historicized the making of Overtown's food desert by examining how food environments and foodways have transformed over the past century. Here I unearthed the vibrant and interdependent neighborhood food system forged by the community-building practices of Colored Town's residents under conditions of racial segregation and economic predation. I argue that Black people used food as a means to create a sense of place and economic autonomy in Miami, a city built upon a foundation of racialized dispossession and exploitation. In so doing, Colored Town residents challenged the design and function of Jim Crow.

I then traced the decline of Overtown's neighborhood food environment through urban renewal, expressway construction, and public divestment. The formation of food deserts, I argue, is an outcome of several interlocking forces, which may include: legal segregation and the spatialization and racialization of wealth creation, the gutting of formerly segregated communities in the postwar/civil rights era, the institutionalized dismantling of and discrimination against Black business, greater capitalist penetration into Black communities during desegregation, structural racism in the development of suburbs and underdevelopment of the inner city, the industrialization of the food system, the rise of supermarkets, and anti-Black violence promulgated by neighborhood policing. Despite these multi-pronged assaults on Black urban life in Miami, Overtown's Black business owners actively fought to maintain a footing in business and in the provision of food, and a handful of groceries and restaurants still exist today. 
I also investigated the spatial politics of a recent urban agriculture project as it intervened into the redevelopment of Miami's once neglected inner city. Characteristic of neoliberal forms of governance emerging since the 1980s, the Roots in the City nonprofit took it upon itself to mobilize city and land trust property, state resources, and organizational and institutional networks to grow fresh food for residents and create jobs for those marginalized by Miami's white and Latino dominated political economy. In addition, Dunn sought to create an alternative model of land use for impoverished communities on the brink of gentrification. Despite his failure to do so, I argue that Roots in the City challenged an ontologically singular mode of urban redevelopment, viewing land in Overtown not as a commodity to make valuable for developers but as a productive, self-sustaining agricultural space that could rearticulate relationships between community, land, labor, health, and the economy.

Finally, I examined contemporary community redevelopment practices, which aim to remake Overtown as a cultural dining and entertainment district in the image of its former "heydays." Based on my empirical findings, I argue that redevelopment practices in Overtown are not only undermining networks of social and economic interdependency in the existing foodscape, but also effectively reproducing the spatial and racial urbicide once delivered by more overt forms of racism.

By linking place-based racial histories to the production of inequitable urban food systems, this dissertation research reveals the underlying geographies of struggle and dispossession that have shaped the production of both food deserts and gentrifying "foodie" districts. Yet, as I have shown, while food matters are central to Overtown's ever-shifting neighborhood ecology, they are also inextricably linked to a spate of other 
issues, such as housing, unemployment, police brutality, mass incarceration, declining social welfare, and displacement and gentrification. In writing this dissertation, it is my hope that food justice activism and scholarship can better connect with broader movements for racial justice. As Audre Lorde once wrote, "There is no such thing as a single-issue struggle, because we do not live single-issue lives" $(1984,183)$.

In August 2016, the Movement for Black Lives - "a collective of more than 50 organizations representing thousands of Black people"-issued a policy platform titled, “A Vision for Black Lives" (The Movement for Black Lives 2016). As part of their multifaceted policy agenda, they demand "reparations for the wealth extracted from our communities through environmental racism, slavery, food apartheid, housing discrimination and racialized capitalism in the form of corporate and government reparations focused on healing ongoing physical and mental trauma, and ensuring our access and control of food sources, housing and land." Such a plan connects the production of healthy food systems to broader matters of land reform and reparations for redressing centuries of race-based injustice. This dissertation on food, race, and the development of space provides the empirical support to better fold food advocacy within political projects for racial justice. 


\section{LIST OF REFERENCES}

Ackerman, K., M. Conard, P. Culligan, R. Plunz, M. Sutto, and L. Whittinghill. 2014. Sustainable food systems for future cities: The potential of urban agriculture. The Economic and Social Review 45 (2): 189-206.

Aldrich, H., and A. J. Reiss Jr. 1976. Continuities in the study of ecological succession: Changes in the race composition of neighborhoods and their businesses. American Journal of Sociology: 846-866.

Alkon A. H., D. Block, K. Moore, C. Gillis, N. DiNuccio, and N. Chavez. 2013. Foodways of the urban poor. Geoforum 48: 126-135.

Alkon, A. H., and C. G. McCullen. 2011. Whiteness and farmers markets: Performances, perpetuations... contestations? Antipode 43 (4): 937-959.

Allen, P., and C. Sachs. 2012. Women and food chains: The gendered politics of food. In Taking Food Public: Redefining Foodways in a Changing World, (eds.) P. WilliamsForson and C. Counihan, 23-40. London and New York: Routledge.

Altonji, J. G., and U. Doraszelski. 2005. The role of permanent income and demographics in black/white differences in wealth. Journal of Human Resources 40 (1): 1-30.

Alvarez, L., T. Pugh, and M. Merzer. 1993. Passions flare, then subside as Orlando jury clears Lozano, black leaders appeal for calm. The Miami Herald, Front, May 29, 1A.

Alwitt, L., and T. Donley. 1997. Retail Stores in Poor Urban Neighborhoods. The Journal of Consumer Affairs 31 (1):139-164.

Anderson, K. 2002. The racialization of difference: Enlarging the story field. The Professional Geographer 54 (1): 25-30.

Ashman, L., J. De La Vega, M. Dohan, A. Fisher, R. Hippler, and B. Romain. 1993. Seeds of Change: Strategies for Food Security for the Inner City.

Baker, L. E. 2004. Tending cultural landscapes and food citizenship in Toronto's community gardens. Geographical Review 94 (3): 305-325.

Beaulac, J., E. Kristjansson, and S. Cummins. 2009. Peer Reviewed: A Systematic Review of Food Deserts, 1966-2007. Preventing Chronic Disease 6 (3).

Bedore, M. 2013. Geographies of capital formation and rescaling: A historicalgeographical approach to the food desert problem. The Canadian Geographer 57 (2):133-153. 
Bell, D. 2007. The hospitable city: Social relations in commercial spaces. Progress in Human Geography 31 (1): 7-22.

Bell, D., and J. Binnie. 2005. What's eating Manchester? Gastro-culture and urban regeneration. Architectural Design 75 (3): 78-85.

Bell, D., and G. Valentine. 1997. Consuming geographies: We are where we eat. Psychology Press.

Bell, D. 2000. Property rights in whiteness: Their legal legacy, their economic costs. In Critical race theory: The cutting edge, (eds.) R. Delgado and J. Stefancic, 71-79. Philadelphia: Temple University Press.

Bivins, L. 1982. Wanted: Supermarket for shopping center in Overtown neighborhood. The Miami Herald, Local, June 28, 2D.

Blanchard, L., B. Zhao, and J. Yinger. 2008. Do lenders discriminate against minority and woman entrepreneurs? Journal of Urban Economics 63 (2): 467-497.

Blanchflower, D. G., P. B. Levine, and D. J. Zimmerman. 2003. Discrimination in the small-business credit market. Review of Economics and Statistics 85 (4): 930-943.

Blau, F. D., and J. Graham. 1990. Black-white differences in wealth and asset composition. Quarterly Journal of Economics 105 (2): 321-339.

Block, D., and J. Kouba. 2006. A comparison of the availability and affordability of a market basket in two communities in the Chicago area. Public Health Nutrition 9 (7): 837-845.

Block, J. P., R. A. Scribner, and K. B. DeSalvo, K. B. 2004. Fast food, race/ethnicity, and income: A geographic analysis. American Journal of Preventive Medicine 27 (3): 211-7.

Blomley, N. K. 2004. Unsettling the city: Urban land and the politics of property. Psychology Press.

Blount, C., W. Ip, I. Nakano, and E. Ng. 2014. Redevelopment agencies in California: History, benefits, excesses, and closure.

Bodenhamer, D. J., J. Corrigan, and T. M. Harris. 2010. The spatial humanities: GIS and the future of humanities scholarship. Bloomington: Indiana University Press.

Bonacich, E., and J. Modell. 1980. The economic basis of ethnic solidarity: Small business in the Japanese American community. Berkeley: University of California Press. 
Bondi, L. 2005. Troubling space, making space, doing space. Group Analysis 38 (1): 137-149.

Bower, A. 2007. African American foodways: Explorations of history and culture. University of Illinois Press.

Brahinsky, R., J. Sasser, and L. Minkoff-Zern. 2014. Race, space, and nature: An introduction and critique. Antipode 46 (5): 1135-1152.

Bridge, G., and R. Dowling. 2001. Microgeographies of retailing and gentrification. Australian Geographer 32 (1): 93-107.

Brookings Institution Center on Urban and Metropolitan Policy. 2003. Miami in focus: A profile from census 2000. Washington, DC: The Brookings Institution.

Brown, D. R., A. Hernández, G. Saint-Jean, S. Evans, I. Tafari, I., L. G. Brewster, and S. Akal. 2008. A participatory action research pilot study of urban health disparities using rapid assessment response and evaluation. American Journal of Public Health 98 (1): 2838.

Browne, S. 2015. Dark matters: On the surveillance of blackness. Durham: Duke University Press.

Bullard, R. D. 2000. Dumping in dixie: Race, class, and environmental quality. Boulder: Westview Press.

Burnett, J. H. 2009. Taking root. The Miami Herald, Front, October 21, 1A.

Burnett, K. 2014. Commodifying poverty: Gentrification and consumption in Vancouver's downtown eastside. Urban Geography 35 (2): 157-176.

Butler, J. S. 2012. Entrepreneurship and self-help among black Americans: A reconsideration of race and economics. SUNY Press.

Cannuscio, C. C., E. E. Weiss, and D. A. Asch. 2010. The contribution of urban foodways to health disparities. Journal of Urban Health 87 (3): 381-393.

Carney, J. 2001. Black rice: The african origins of rice cultivation in the Americas. Cambridge: Harvard University Press.

Castillo, T. A. 2008. Chauffeuring in a white man's town: Black service work, movement and segregation in early Miami, in Florida's working-class past: Current perspectives on labor, race, and gender from Spanish Florida to the new immigration, (eds.) R. Cassenello and M. Shell-Weiss, 143-67. Gainesville: University of Florida Press. 
Cavalluzzo, K., and L. Cavalluzzo, and J. Wolken, 2002. Competition, small business financing, and discrimination evidence from a new survey. Journal of Business 75: 641680 .

Cavalluzzo, K., and J. Wolken. 2005. Small business loan turndowns, personal wealth, and discrimination. The Journal of Business 78 (6): 2153-2178.

Cavanaugh, J. 1994. Ire in Overtown Disputes Threaten market that gave area hope. Miami Herald, Neighbors NC, November 3, 3.

Charles, J. 1995. Seeds of Renewal. The Miami Herald, Local, October 15, 1B.

Chen, D., E. C. Jaenicke, and R. J. Volpe. 2016. Food environments and obesity: Household diet expenditure versus food deserts. American Journal of Public Health 106 (5): 881-888.

Chung, C., and S. L. Myers. 1998. Do the poor pay more for food? An analysis of grocery store availability and food price disparities. Journal of Consumer Affairs 33 (2): 276-296.

City of Miami. 1961. A Comprehensive Analysis of Miami’s Neighborhoods.

City of Miami. 2014. SEOPW Community Redevelopment Agency meeting minutes. March 31.

December 12 .

2015. SEOPW Community Redevelopment Agency meeting minutes.

City of Miami Planning Department 2009. Southeast Overtown/Park West Community Redevelopment Plan. 2009 Update to the 2004 Plan.

Clary, M. 1992. Cult Leader Convicted of Murder Conspiracy: Crime: Yahweh ben Yahweh and six of his followers are found guilty in a Miami trial marked by testimony of beheadings, mutilation. The Los Angeles Times, May 28, Retrieved 11 February 2016, from http://articles.latimes.com/1992-05-28/news/mn-444_1_yahweh-murders-followers.

Cochrane, W. W. 1993. The development of American agriculture: A historical analysis. Minneapolis: University of Minnesota Press.

Coleman, S. 2002. The borrowing experience of black and Hispanic-owned small firms: Evidence from the 1998 survey of small business finances. Academy of Entrepreneurship Journal 8 (1): 1.

Coleman, S. 2005. Is there a liquidity crisis for small, black-owned firms? Journal of Developmental Entrepreneurship 10 (1): 29-47. 
Coleman-Jensen, A., C. Gregory, and A. Singh. 2014. Household food security in the United States in 2013. USDA-ERS Economic Research Report.

Connolly, N. D. B. 2006. Colored, Caribbean, and condemned: Miami's Overtown district and the cultural expense of progress, 1940-1970. Caribbean Studies 34 (1): 7-8.

2008. Timely innovations: Planes, trains, and the 'whites only' economy of a pan-American City. Urban History 36 (2): 246.

-----------. 2014. A world more concrete: Real estate and the remaking of jim crow south Florida. Chicago: University of Chicago Press.

Corral, O. 2003. Overtown: Urban renewal millions yield little. The Miami Herald, Front, October $12,1 \mathrm{~A}$.

Corry, J. 1968 [1807]. Observations upon the windward coast of Africa: The religion, character, customs, etc. of the natives. London: Frank Cass.

Cotterell, W. 1980 Unemployment, injustices blamed for blowup. The Afro American, May 31, 6.

Crang, M., and Cook, I. 2007. Doing ethnographies. London: Sage.

Creel, M. 1988. “A peculiar people”: Slave religion and community-culture among the Gullahs. New York: New York University Press.

Cross, Jennifer. 1976. The supermarket trap: Consumer and the food Industry. Indiana: Indiana University Press.

Cruickshank. B. 1966 [1853]. Eighteen years on the Gold Coast of Africa: Including an account of the native tribes, and their intercourse with Europeans. Volume two. London: Frank Cass.

Cummins, S., Flint, E., and Matthews, S. A. 2014. New neighborhood grocery store increased awareness of food access but did not alter dietary habits or obesity. Health Affairs (Project Hope) 33 (2): 283-291.

Curtis, K. A., and McClellan, S. 1995. Falling through the safety net: Poverty, food assistance and shopping constraints in an American city. Urban Anthropology and Studies of Cultural Systems and World Economic Development: 93-135.

de Certeau, M. 1984. The practice of everyday life. Berkeley: University of California Press. 
Del Casino, V. J. 2015. Social geography I: Food. Progress in Human Geography 39 (6): $800-808$.

Delaney, D. 2002. The space that race makes. The Professional Geographer 54 (1): 6-14.

Delgado, R., and J. Stefancic. 2012. Critical race theory: An introduction. New York: New York University Press.

Dluhy, M., K. Revell, and S. Wong. 2002. Creating a positive future for a minority community: Transportation and urban renewal politics in Miami. Journal of Urban Affairs 24 (1): 75-95.

Doreen, M. 1994. Space, place and gender. Minneapolis: University of Minnesota Press.

Dreier, P., J. H. Mollenkopf, and T. Swanstrom. 2004. Place matters: Metropolitics for the twenty-first century. University Press of Kansas.

Drewnowski, A., A. Aggarwal, P. M. Hurvitz, P. Monsivais, and A. V. Moudon. 2012. Obesity and supermarket access: Proximity or price? American Journal of Public Health 102 (8): e74-e80.

Du Bois, W. E. B. 1898. The negro in business. Atlanta University.

Dunn, M. 1997. Black Miami in the twentieth century. Gainesville: University Press of Florida. 2011. Overtown market a victim of politics. The Miami Herald, March 31.

Dwyer, C., and C. Bressey, C. 2008. New geographies of race and racism. Ashgate Publishing, Ltd.

Eastman, S. 2002. Dred, you got okra? The Miami New Times, December 27, Retrieved 10 April 2016, from http://www.miaminewtimes.com/news/dred-you-got-okra-6351745

Egger, G., and B. Swinburn. 1997. An "ecological" approach to the obesity pandemic. $B M J 315: 477$.

Eisenhauer, E. 2001. In poor health: Supermarket redlining and urban nutrition. GeoJournal 53: 125-133.

Eizenberg, E. 2012. Actually existing commons: Three moments of space of community gardens in new york city. Antipode 44 (3): 764-782.

Elbel, B., A. Moran, L. B. Dixon, K. Kiszko, J. Cantor, C. Abrams, and T. Mijanovich. 2015. Assessment of a government-subsidized supermarket in a high-need area on 
household food availability and children's dietary intakes. Public Health Nutrition 18 (15): 2881-2890.

Faber, J. P. 1982. Miami riot area stays quiet. The Bryan Times, Front, December 30, 1.

Fagenson, Z. 2016. Marcus Samuelsson begins negotiations with Overtown restaurant. The Miami New Times, March31, Retrieved 5 May 2016, from http://www.miaminewtimes.com/restaurants/marcus-samuelsson-begins-negotiations-forovertown-restaurant-8358304

Fairlie, R. W., and A. M. Robb. 2007. Why are black-owned businesses less successful than white-owned businesses? The role of families, inheritances, and business human capital. Journal of Labor Economics 25 (2): 289-323.

----------- 2008. Race and entrepreneurial success: Black-, asian-, and white-owned businesses in the United States. Cambridge: MIT Press.

Farnsworth, P. and L. A. Wilkie. 2006. Fish and grits: Southern, African, and British influences in Bahamian foodways, In Caribbean and Southern: Transnational Perspectives on the U. S. South, (ed.) H. A. Regis. Athens: University of Georgia Press.

Ferguson, E. 1983a. Selling Overtown Tougher Now. The Miami Herald, Neighbors NW, January 9,3 .

--.--. 1983b. Money, Imagination Needed in Overtown. The Miami Herald, Neighbors NW, March 20, 4.

Fesperman, D. 1982. Black business gambits for getting beyond square 1. The Miami Herald, Business, July 12, 1BM.

Food Research and Action Center. Food Hardship in America 2010. 2011. Retrieved 13 December 2015, from

http://www.frac.org/pdf/aug2011_food_hardship_report_children.pdf

Ford, P. B., and D. A. Dzewaltowski. 2010. Limited supermarket availability is not associated with obesity risk among participants in the Kansas WIC program. Obesity 18 (10): 1944-1951.

Foucault, M. 2008. The birth of biopolitics: Lectures at the collège de france, 19781979. Springer.

Freedberg, S. P. 1994. Brother love: Murder, money, and a messiah. Pantheon Books.

Freedberg, S., and E. Ferguson. 1983. Overtown one year later: The living's no easier. The Miami Herald, Front, December 28, 1A. 
Gainsborough, J. F. 2008. A tale of two cities: Civic culture and public policy in Miami. Journal of Urban Affairs 30 (4): 419-435.

Gallagher, M. 2007. Examining the impact of food deserts on public health in Detroit. Chicago, IL: Mari Gallagher Research and Consulting Group,

Geertz, C. 1973. The interpretation of cultures: Selected essays. Basic books.

Gilmore, R. W. 2002. Fatal couplings of power and difference: Notes on racism and geography. The Professional Geographer 54 (1): 15-24.

Gilmore, R. W. 2007. Golden gulag: Prisons, surplus, crisis, and opposition in globalizing California. Berkeley: University of California Press.

Goldberg, D. T. 2002. The racial state. Blackwell Publishing.

Goldfarb, C. 1990. City concessions helped Gary set up deals with Yahwehs. The Miami Herald, Local, May 13, $2 \mathrm{~B}$.

Gonzalez, S., and P. Waley. 2012. Traditional retail markets: The new gentrification frontier? Antipode 45: 965-983.

Gordon, C., M. Purciel-Hill, N. R. Ghai, L. Kaufman, R. Graham, and G. Van Wye. 2011. Measuring food deserts in New York City's low-income neighborhoods. Health and Place 17 (2): 696-700.

Gotham, K. F. 2005. Tourism gentrification: The case of New Orleans' Vieux Carre (French Quarter). Urban Studies 42 (7): 1099-1121.

Grimm, F. 1980. Black rage ruins the dream of restoring Overtown's glory. The Miami Herald, May 20, 19A.

------------. 1983. Blacks get no immunity. The Miami Herald, Local, January 1, $1 \mathrm{~B}$.

Grimm, F., and B. Bearak. 1980. Dream of a new Overtown now lies in ashes. The Miami Herald, Dade News, May 20, 1B-2B.

Guniss, C. 2016. Overtown, food desert no more. Miami Times, Retrieved 14 October 2016, from http://www .miamitimesonline.com/business/overtown-food-desert-nomore/article_a1df16b2-9092-11e6-8972-6f08659ec6c4.html

Guthman, J. 2008. Neoliberalism and the making of food politics in California. Geoforum 39 (3): 1171-1183. 
----------. 2011. Weighing in: Obesity, food justice and the limits of capitalism. Berkeley: University of California Press.

Hackworth, J., and N. Smith. 2001. The changing state of gentrification. Tijdschrift Voor Economische En Sociale Geografie 92 (4): 464-477.

Hahamovitch, C. 1997. The fruits of their labor: Atlantic coast farmworkers and the making of migrant poverty, 1870-1945. Chapel Hill: University of North Carolina Press.

---------. 2011. No man's land: Jamaican guestworkers in America and the global history of deportable labor. Princeton University Press.

Hall, B. Food stamps and WIC. In Food issues: An encyclopedia, (ed.) Ken Albala, 626-632. Thousand Oaks: Sage.

Hall, R. L. 2007. Food crops, medicinal plants, and the Atlantic slave trade. In African American foodways: explorations of history and culture, (ed.) A. Bower, 17-44.

University of Illinois Press.

Hall, S. 1992. Race, culture, and communications: Looking backward and forward at cultural studies. Rethinking Marxism 5 (1): 10-18.

Haraway, D. 1988. Situated knowledges: The science question in feminism and the privilege of partial perspective. Feminist Studies 14 (3): 575-599.

Harris, C. I. 1993. Whiteness as property. Harvard Law Review, 1707-1791.

Harris, J. B. 2011. High on the hog: A culinary journey from Africa to America. Bloomsbury Publishing.

Harvey, D. 1973. Social justice and the city. Baltimore: Johns Hopkins University Press. - 1981. The spatial fix - Hegel, Von Thunen, and Marx. Antipode 13 (3): 1-12. 1989. From managerialism to entrepreneurialism: The transformation of governance in late capitalism. Geografiska Annaler 71 (B): 3-17.

-----------. 1990. The condition of postmodernity: An enquiry into the origins of cultural change. Oxford: Blackwell.

Hawthorne, C., and B. Meché. 2016. Making room for black feminist praxis in geography. Commentary for Environment and Planning D: Society and Space. Retrieved 2 October 2016, from https://societyandspace.com/material/commentaries/camillahawthorne-and-brittany-meche-making-room-for-black-feminist-praxis-in-geography/ 
Hay, I. 2000. Qualitative research methods in human geography.

Hendrickson, D., C. Smith, C., and N. Eikenberry. 2006. Fruit and vegetable access in four low-income food deserts communities in Minnesota. Agriculture and Human Values, 23 (3): 371-383.

Herbert, S. 2000. For ethnography. Progress in Human Geography 24 (4): 550-568.

Hirsch, A. R. 2008. Making the second ghetto: Race and housing in chicago, 19401960. Chicago: University of Chicago Press.

Hollander, G. 2006. 'Subject to control': Shifting geographies of race and labour in US sugar agroindustry, 1930-1950. Cultural Geographies 13 (2): 266-292.

Hoffman, L. M. 2003. The marketing of diversity in the inner city: Tourism and regulation in Harlem. International Journal of Urban and Regional Research 27 (2): 286299.

Humphery, K. 1998. Shelf life: Supermarkets and the changing cultures of consumption. Cambridge University Press.

Hyra, D. S. 2008. The new urban renewal: The economic transformation of harlem and bronzeville University of Chicago Press.

Jackson, P. 1987. The idea of 'race' and the geography of racism. Race and Racism: Essays in Social Geography, 3-21.

Jacobs, S. 1986. Markets kept Overtown stocked. The Miami Herald, Living Today, January $27,1 \mathrm{C}$.

Jarosz, L. 2000. Understanding agri-food networks as social relations. Agriculture and Human Values 17 (3): 279-283.

Johnson, C. S. 1930. The Negro in American Civilization: A Study of Negro Life and Race Relations in Light of Social Research. Henry Holt and Co.

Jonas, A. E., and McCarthy, L. 2008. Urban management and regeneration in the United States: State intervention or redevelopment at all costs? Local Government Studies 35 (3): 299-314.

Joyner, C. 1984. Down by the Riverside: A South Carolina Slave Community. Urbana: University of Illinois Press.

Klinenberg, E. 2015. Heat wave: A social autopsy of disaster in Chicago. Chicago: University of Chicago Press. 
Kobayashi, A. 1990. Racism and law in Canada: A geographical perspective. Urban Geography 11 (5): 447-473.

Kobayashi, A., and L. Peake. 1994. Unnatural discourse: 'Race' and gender in geography. Gender, Place and Culture: A Journal of Feminist Geography 1 (2): 225-243.

2000. Racism out of place: Thoughts on whiteness and an antiracist geography in the new millennium. Annals of the Association of American Geographers 90 (2): 392403.

Kotkin, J. 1986. The Reluctant Entrepreneurs. Inc. September 1. Retrieved February 11, 2016, from http://www.inc.com/magazine/19860901/300.html

Kurtz, H. 2001. Differentiating multiple meanings of garden and community. Urban Geography 22 (7): 656-670.

2013. Linking food deserts and racial segregation: Challenges and limitations. In Geographies of race and food: Fields, bodies, markets, (eds.) R. Slocum and A. Saldanha, 248-264. Ashgate Press.

Kwate, N.O.A. 2008. Fried chicken and fresh apples: Racial segregation as a fundamental cause of fast food density in Black neighborhoods. Health and Place 14 (1): 32-44.

Kwate, N.O.A., C. Yau, J. Loh, and D. Williams. 2009. Inequality in obesogenic environments: Fast food density in New York City. Health and Place 15: 364-373.

Larsen, K., B. Cook, M. R. Stone, and G. E. Faulkner. 2015. Food access and children's BMI in Toronto, Ontario: Assessing how the food environment relates to overweight and obesity. International Journal of Public Health 60 (1): 69-77.

Lassiter, T., and M. Billington. 1989. The struggle goes on store owner: 'I'm barely making it.' The Sun Sentinel, July 16, Retrieved March 23, 2016, from http://articles.sunsentinel.com/1989-07-16/news/8902210021_1_sniper-liberty-city-promise

Lee, H. 2012. The role of local food availability in explaining obesity risk among young school-aged children. Social Science and Medicine, 74 (8): 1193-1203.

Lee, J. 2002. Civility in the city: Blacks, Jews, and Koreans in urban America. Cambridge: Harvard University Press.

Lefebvre, H. 1991. The production of space. Oxford: Blackwell.

Let's Move! 2016. Retrieved 27 September 2016, from http://www.letsmove.gov/healthycommunities. 
Lewicki, T. and M. Johnson. 1974. West African food in the middle ages according to Arabic sources. London: Cambridge University Press.

Ley, D. 1994. Gentrification and the politics of the new middle class. Environment and Planning D: Society and Space 12: 53-74.

Lipsitz, G. 1998. Possessive investment in whiteness: How white people profit from identity politics. Philadelphia: Temple University Press.

-----------. 2011. How racism takes place. Philadelphia: Temple University Press.

Logan, J. R., and B. J. Stults. 2010. Racial and ethnic separation in the neighborhoods: Progress at a standstill. Project US2010. Retrieved September 11, 2015 from http://www.s4.Brown.edu/us2010/Data/Report/report1.pdf

Lopez, I. F. H. 1997. White by law: The legal construction of race. New York: New York University Press.

Lowe, B. and E. Ferguson. 1983. Urban Renewal, Expressways Ripped Soul From Overtown. The Miami Herald, Front, 1A.

Lyson, T. A. 2012. Civic agriculture: Reconnecting farm, food, and community. Medford: Tufts University Press.

MacDonald, J. M., and P. E. Nelson. 1991. Do the poor still pay more? Food price variations in large metropolitan areas. Journal of Urban Economics 30 (3): 344-359.

Manchester, A. C. 1992. Rearranging the economic landscape: The food marketing revolution, 1950-91. Agricultural Economic Report No. 660, Commodity Economics Division, Economic Research Service, US Department of Agriculture.

Marable, M. 2015. How capitalism underdeveloped black America: Problems in race, political economy, and society. Haymarket Books.

Mares, T. M., and D. G. Peña. 2010. Urban agriculture in the making of insurgent spaces in Los Angeles and Seattle. In Insurgent Public Space: Guerrilla Urbanism and the Remaking of Contemporary Cities, (ed.) J. Hou, 241-254. London and New York: Routledge.

Massey, D. S., and N. A. Denton. 1993. American apartheid: Segregation and the making of the underclass. Cambridge: Harvard University Press.

Mbembe, A. 2003. Necropolitics. Public Culture 15 (1): 11-40. 
McClintock, N. 2011. From industrial garden to food desert: Demarcated devalution in the flatlands of Oakland, California. In Cultivating Food Justice: Race, Class, and Sustainability, (eds.) A. Alkon and J. Agyeman. Cambridge: MIT Press.

------------. 2014). Radical, reformist, and garden-variety neoliberal: Coming to terms with urban agriculture's contradictions. Local Environment 19 (2): 147-171.

McKittrick, K. 2011. On plantations, prisons, and a black sense of place. Social and Cultural Geography 12 (8): 947-963.

-----------. 2013. Plantation futures. Small Axe, 17 (3/42): 1-15.

McKittrick, K., and C. A. Woods. 2007. Black geographies and the politics of place. Toronto: Between the Lines.

McLafferty, S., and V. Preston, V. 1992. Spatial mismatch and labor market segmentation for African-American and Latina women. Economic Geography 68 (4): 406-431.

Metro Dade Planning Department. 1960. The Magic City Center Plan for Action.

Miami Herald Staff. 1920. Miami, 1,681 in 1900, Now Third Florida City with 1920 Population 29,549. May 27.

1982. Work Begins in Overtown on Supermarket Project. The Miami Herald, Local, October 31, 5B.

The Miami Metropolis. 1916. Greatest Year In Real Estate The Prediction Of All Dealers, October 27.

The Miami News. 1945. Grape Vineyards May Rival Citrus Crops In Florida, The Miami News. May 11.

Miewald, C., and E. McCann. 2014. Foodscapes and the geographies of poverty: Sustenance, strategy, and politics in an urban neighborhood. Antipode 46 (2): 537-556.

Mohl, R. A. 1987. Black immigrants: Bahamians in early twentieth-century Miami. The Florida Historical Quarterly 65 (3): 271-297.

----------. 1989. Shadows in the sunshine: Race and ethnicity in Miami. Tequesta: The Journal of the Historical Association of South Florida 49: 63-80.

1998. "South of the south?" Jews, blacks, and the civil rights movement in Miami, 1945-1960. Journal of American Ethnic History 3-36. 
Moore, L. V., and A. V. Diez Roux. 2006. Associations of neighborhood characteristics with the location and type of food stores. American Journal of Public Health 96 (2): 325331.

Moran, D. 2015. Carceral geography: Spaces and practices of incarceration. Ashgate Publishing, Ltd.

Morland, K., and S. Filomena. 2007. Disparities in the availability of fruits and vegetables between racially segregated urban neighbourhoods. Public Health Nutrition 10 (12): 1481-1489.

Morland, K., S. Wing, A. D. Roux, and C. Poole. 2002. Neighborhood characteristics associated with the location of food stores and food service places. American Journal of Preventive Medicine 22 (1): 23-29.

The Movement for Black Lives. 2016. A vision for black lives: Policy demands for black power, freedom, and justice. Retreived 31 August 2016, from https://policy.m4bl.org

National Commission on Food Marketing. 1966. Prices charged in stores in low and high income areas of 6 large cities. Special Studies in Food Marketing, 121-44.

Neal, Z. P. 2006. Culinary deserts, gastronomic oases: A classification of US cities. Urban Studies 43 (1): 1-21.

Neely, B., and M. Samura. 2011. Social geographies of race: Connecting race and space. Ethnic and Racial Studies 34 (11): 1933-1952.

New York Law School Racial Justice Project, and Racial Justice Program of the American Civil Liberties Union. 2012. Unshared bounty: How structural racism contributes to the creation and persistence of food deserts. Retrieved 16 March 2016, from

http://www.racialjusticeproject.com/wp-content/uploads/2012/06/NYLS-Food-DesertsReport.pdf

Neilsen, K. 1999. Less for Moore. The Miami New Times, November 25, Retrieved 15 January 2016, from http://www .miaminewtimes.com/news/less-for-moore-6357525

----------. 2002. Teele's (Or)Deal. The Miami New Times, August 15, Retrieved 6 April 2016, from http://www.miaminewtimes.com/news/teeles-or-deal-6349924

Nieves, A. D., and L. M. Alexander, L. M. 2008. "We shall independent be": African American place making and the struggle to claim space in the United States. Boulder: University Press of Colorado. 
Niño, P. 2011. City cracks down on Overtown, Liberty City farmers markets.” The Miami New Times, March 30, Retrieved April 10 2016, from http://www.miaminewtimes.com/restaurants/city-cracks-down-on-overtown-liberty-cityfarmers-markets-updated-6580514

Ogden, C. L., Carroll, M. D., Kit, B. K., and Flegal, K. M. 2014. Prevalence of childhood and adult obesity in the United States, 2011-2012. Journal of the American Medical Association 311 (8): 806-814.

Oliver, A. 2008. A big bet, a bigger challenge: Knight Foundation's investment in Overtown. John S. and James L. Knight Foundation. September.

Oliver, M. L., and Shapiro, T. M. 2006. Black wealth, white wealth: A new perspective on racial inequality. Taylor and Francis.

Olivieri, A. L. 2011. A Community Food System Plan for Miami-Dade County:

F.H.E.E.D. Florida Atlantic University. Masters thesis.

Omi, M., and H. Winant. 1994. Racial formation in the United States:From the 1960s to the 1990s. New York and London: Routledge.

Opie, F. D. 2010. Hog and hominy: Soul food from Africa to America. New York: Columbia University Press.

Ovalle, D., and W. Sayre. 2014. Crackdown on crossings riles residents. The Miami Herald, September 17, Retrieved June 20 2016, from http://www.miamiherald.com/news/local/crime/article2143126.html

The People for Truth. 1994. The persecution of Yahweh Ben Yahweh: Volume One. Peters, M. A. 2001. Poststructuralism, marxism, and neoliberalism: Between theory and politics Rowman \& Littlefield.

Peters, T. 1985. Miami 1909, with excerpts from Fannie Clemons’ Diary. Miami: Banyan Books.

Poe, T. N. 1998. The origins of soul Food in black urban identity: Chicago, 1915-1947. American Studies International 37 (1): 4-33.

Polanyi, K. 1944. The great transformation: Economic and political origins of our time. New York: Farrar and Rinehart.

Poppendieck, J. 1998. Sweet charity?: Emergency food and the end of entitlement. Penguin. 
---------. 2014. Food assistance, hunger and the end of welfare in the USA. In First world hunger revisited, (eds.) G. Riches and T. Silvasti, 176-190. Springer.

Porter, B., and M. Dunn. 1981. Exclusion from American economic life cause of Miami riots. Lakeland Ledger, May 24, 19A.

Books.

1984. The Miami riot of 1980: Crossing the bounds. Lexington: Lexington

Portes, A., and L. Jensen. 1988. The enclave and the entrants: Patterns of ethnic enterprise in Miami before and after Mariel. American Sociological Review 929-949.

Portes, A., and A. Stepick. 1993. City on the edge: The transformation of Miami. Berkeley: University of California Press.

Pothukuchi, K. 2005. Attracting supermarkets to inner-city neighborhoods: Economic development outside the box. Economic Development Quarterly 19 (3): 232-244.

Powell, L. M., S. Slater, D. Mirtcheva, Y. Bao, and F. J. Chaloupka. 2007. Food store availability and neighborhood characteristics in the United States. Preventive Medicine 44 (3): 189-195.

Price, P. L. 2008. At the crossroads: Critical race theory and critical geographies of race. Progress in Human Geography 34 (2): 147-174.

Pudup, M. B. 2008. It takes a garden: Cultivating citizen-subjects in organized garden projects. Geoforum 39 (3): 1228-1240.

Pulido, L. 2000. Rethinking environmental racism: White privilege and urban development in southern California. Annals of the Association of American Geographers 90 (1): 12-40.

Pulido, L. 2015. Geographies of race and ethnicity I: White supremacy vs white privilege in environmental racism research. Progress in Human Geography. doi:

$10.1177 / 0309132514563008$

Quastel, N. 2008. Political ecologies of gentrification. Urban Geography, 30 (7): 694725 .

Rabin, C., and L. Burgess. 2011. Roots in the City ups the stakes, now demanding $\$ 3$ million from Miami's CRA - A professor who runs an inner-city training and gardening venture leads a march to help his cause: expansion. The Miami Herald, April 2. 
Raja, S., C. Ma, and P. Yadav, P. 2008. Beyond food deserts measuring and mapping racial disparities in neighborhood food environments. Journal of Planning Education and Research 27 (4): 469-482.

Ramírez, M. M. 2015. The elusive inclusive: Black food geographies and racialized food spaces. Antipode 47 (3): 748-769.

Reid, I. D. A. 1939. The negro immigrant: His background, characteristics, and social adjustment, 1899-1937. New York: Columbia University Press; London: PS King \& son, Limited.

Riches, G., and Silvasti, T. 2014. First world hunger revisited: Food charity or the right to food? Springer.

Rohter, L. 1993. Miami Police Officer Is Acquitted In Racially Charged Slaying Case. The New York Times, May 29, Retrieved 5 March 2016 from, http://www.nytimes.com/1993/05/29/us/miami-police-officer-is-acquitted-in-raciallycharged-slaying-case.html

Roman, I., and R. Ramos. 1989. Violence Ebbs. The Miami Herald, Front, January 19, $1 \mathrm{~A}$.

Saldanha, A. 2011. Race. In Companion to Human Geography, (eds.) J. Agnew and J. Duncan, 453-464. London: Sage.

Sassen, S., and A. Portes. 1993. Miami: A new global city? Contemporary Sociology 22 (4): 471-477.

Scott, J. C. 1998. Seeing like a state: How certain schemes to improve the human condition have failed. New Haven: Yale University Press.

Seth, A., and G. Randall. 1999. The grocers: The rise and rise of the supermarket chains. Kogan Page Publishers.

Shabazz, R. 2015. Spatializing blackness: Architectures of confinement and black masculinity in Chicago. University of Illinois Press.

Shannon, J. 2013. Food deserts: Governing obesity in the neoliberal city. Progress in Human Geography 38 (2): 248-266.

Shapiro, T. M. 2004. The hidden cost of being African American: How wealth perpetuates inequality. Oxford University Press, USA.

Sharpless, R. 2010. Cooking in other women's kitchens: Domestic workers in the south, 1865-1960. Chapel Hill: University of North Carolina Press. 
Shell-Weiss, M. 2009. Coming to Miami: A social history. Gainesville: University Press of Florida.

Short, A., J. Guthman, and S. Raskin. 2007. Food deserts, oases, or mirages? Small markets and community food security in the San Francisco bay area. Journal of Planning Education and Research 26 (3): 352-364.

Slocum, R. 2007. Whiteness, space and alternative food practice. Geoforum 38 (3): 520533.

Slocum, R., and A. Saldanha. 2016. Geographies of race and food: Fields, bodies, markets. Ashgate..

Smith, A., and B. Kraig. 2013. The Oxford encyclopedia of food and drink in America. Oxford University Press.

Smith, N. 1979. Toward a theory of gentrification: A back to the city movement by capital, not people. Journal of the American Planning Association 45 (4): 538-548.

1987. Gentrification and the rent gap. Annals of the Association of American Geographers 77 (3): 462-465.

Specht, K., R. Siebert, I. Hartmann, U. B. Freisinger,M. Sawicka, A. Werner, and A. Dierich. 2014. Urban agriculture of the future: An overview of sustainability aspects of food production in and on buildings. Agriculture and Human Values 31 (1): 33-51.

Sports Elite Admin. 2012. Interview with President and CEO Leroy Jones of Neighbors And Neighbors Association (NANA). Sports Elite: The New Generation, February 1, Retrieved 3 March 2016, from http://sportselitemag.com/?p=852

Squires, G. D., and C. E. Kubrin. 2005. Privileged places: Race, uneven development and the geography of opportunity in urban America. Urban Studies 42 (1): 47-68.

Stepick, A. 1992. The refugees nobody wants: Haitians in Miami. In Miami now!: Immigration, ethnicity, and social change, (eds.) G. Grenier and A Stepick, 57-82. Gainesville: University of Florida Press.

Stepick, A., G. Grenier, M. Castro, and M. Dunn. 2003. This land is our land: Immigrants and power in Miami. Berkeley: University of California Press.

Sugrue, T. J. 2014. The origins of the urban crisis: Race and inequality in postwar Detroit: Princeton University Press. 
Starita, J. 1983. Legal system frustrates grocer who was robbed. The Miami Herald, Local, January 10, 2 D.

Sullivan, D. M. 2014. From food desert to food mirage: Race, social class, and food shopping in a gentrifying neighborhood. Advances in Applied Sociology 4 (1): 30-35.

Sutton, S. 2015. The geopolitics of black business closure in central Brooklyn. In Race and retail: Consumer culture, economic citizenship, and power, (eds). M. Bay and A. Fabian. Rutgers University Press.

Swinburn, B., G. Egger, and R. Fezeela. 1999. Application of a Framework for Identifying and Prioritizing Environmental Interventions for Obesity. Preventative Medicine 29 (6): 563-570.

Tedlow, R. S. 1996. New and improved: The story of mass marketing in America. Cambridge: Harvard Business School Press.

Thomas, R. 1985a. The Miami Herald, Neighbors NW, April 25, 8.

----------. 1985b. Debt forces closing of city-sponsored Overtown grocery. The Miami Herald, Local, May 15, 3D.

Thomsen, M. R., R. M. Nayga, J. Alviola IV, A. Pedro, and H. L. Rouse. 2015. Living in an urban food desert is a risk factor for weight gain during childhood. USApp-American Politics and Policy Blog.

United States Census Bureau. 1942. Housing: Supplement to the First Series Housing Bulletin for Florida: Miami: Block Statistics. Washington, DC: Government Printing Office.

United States Conference of Mayors: Food Policy Task Force. 2016 Usmayors.org. Retrieved 27 September 2016, from http://www.usmayors.org/foodpolicy/

US Department of Agriculture Economic Research Service. 2009.

Report to Congress: Access to Affordable and Nutritious Food: Measuring and Understanding Food Deserts and their Consequences. Washington, D.C.: ERS/FNS/CSREES.

Ver Ploeg, M., and I. Rahkovsky. 2016. Recent evidence on the effects of food store access on food choice and diet quality. Amber Waves, May. Washington, DC: US Department of Agriculture, Economics Research Service.

Viglucci, A. 2006. Conflict slows Overtown project. The Miami Herald, Metro \& State, August 7, 1B. 
Vlach, J. M. 1986. The shotgun house: An African architectural legacy, In Common places: Readings in American vernacular architecture, (eds). D. Upton and J. M. Vlach, 58-78. Athens: University of Georgia Press.

Wacquant, Loïc. 2007. Territorial stigmatization in the age of advanced marginality. Thesis Eleven 91 (1): 66-77.

Waldinger, R. D., H. Aldrich, and R. Ward. 1990. Ethnic entrepreneurs: Immigrant business in industrial societies. London: Sage.

Walker, E. 2010. Affordable food nourishes neighborhood. The Miami Herald. Front, March 31, 1A.

Walker, J. E. 2009. The history of black business in America: Capitalism, race, entrepreneurship UNC Press Books.

Wallach, J. J. 2015. Dethroning the deceitful pork chop: Rethinking African American foodways from slavery to Obama. University of Arkansas Press.

West, C. 1993. Race matters. Vintage.

White, M. J. 1984. Racial and ethnic succession in four cities. Urban Affairs Review 20 (2): 165-183.

Whited, C. 1980. Dade blacks still alienated and polarized. The Miami Herald, Dade News, May 20, 1B-2B.

Williams, D., and C. Collins. 2001. Racial residential segregation: A fundamental cause of racial disparities in health. Public Health Reports 116 (5): 404-416.

Williams-Forson, P. A. 2006. Building houses out of chicken legs: Black women, food, and power. Chapel Hill: University of North Carolina Press.

Wilson, B. M. 2012. Capital's need to sell and Black economic development. Urban Geography 33 (7): 961-978.

Wilson, K. L., and A. Portes. 1980. Immigrant enclaves: An analysis of the labor market experiences of Cubans in Miami. American Journal of Sociology 295-319.

Wilson, W. J. 2011. When work disappears: The world of the new urban poor. Vintage. 2012. The truly disadvantaged: The inner city, the underclass, and public policy. Chicago: University of Chicago Press. 
Winson, A. 2013. The industrial diet: The degradation of food and the struggle for healthy eating. New York: New York University Press.

Winterbottom, T. 1969 [1803]). An account of the native Africans in the neighborhood of Sierra Leone to which is added an account of the present state of medicine among them, Volume one. London: Frank Cass.

Witt, D. 1999. Black hunger: Food and the politics of US identity. Oxford University Press.

Woods, C. 2005. New restaurant helps you go for the glo. The Miami Herald, Neighbors, September 8, 3MB.

Woods, C. A. 1998. Development arrested: The blues and plantation power in the Mississippi Delta. Verso.

Wrigley, N., C. Guy, and M. Lowe. 2002. Urban regeneration, social inclusion and large store development: The Seacroft sevelopment in context. Urban Studies 39 (11): 21012114.

Yentsch, A. 2007. Excavating the south's African American foodways. In African American foodways: Explorations of history and culture, (ed.) A. Bower, 59-100. University of Illinois Press.

Zenk, S. N., A. J. Schulz, B. A. Israel, S. A. James, S. Bao, and M. L. Wilson. 2005. Neighborhood racial composition, neighborhood poverty, and the spatial accessibility of supermarkets in metropolitan Detroit. American Journal of Public Health 95 (4): 660667.

Zimmerman, Max. 1955. The super market: A revolution in distribution. New York: McGraw-Hill.

Zucker, N. L., and N. F. Zucker. 1996. Desperate crossings: Seeking refuge in America. Sharpe. 
APPENDIX A

A. Interview Matrix

\begin{tabular}{|c|c|c|c|c|c|c|c|}
\hline $\begin{array}{l}\text { Interviewee } \\
\text { (pseudonym) }\end{array}$ & Sex & $\begin{array}{l}\text { Age } \\
\text { range }\end{array}$ & Race/Ethnicity & Nationality & $\begin{array}{l}\text { Relationship to } \\
\text { Overtown }\end{array}$ & $\begin{array}{l}\text { Date of } \\
\text { Interview }\end{array}$ & $\begin{array}{l}\text { Place of } \\
\text { Interview }\end{array}$ \\
\hline Larry & $\mathrm{M}$ & $65-75$ & Black & Unknown & Resident & $\begin{array}{l}\text { November } \\
4,2014\end{array}$ & $\begin{array}{l}\text { Overtown } \\
\text { grocery }\end{array}$ \\
\hline Rhonda & $\mathrm{F}$ & $55-65$ & Black & Unknown & Resident & $\begin{array}{l}\text { November } \\
4,2014\end{array}$ & $\begin{array}{l}\text { Overtown } \\
\text { grocery }\end{array}$ \\
\hline Ray & $\mathrm{M}$ & $50-60$ & Black & USA & Resident & $\begin{array}{l}\text { November } \\
4,2014 \text { / } \\
\text { January 9, } \\
2015 \text { / } \\
\text { March 12, } \\
2015 \text { / July } \\
30,2015\end{array}$ & $\begin{array}{l}\text { Park bench / } \\
\text { Walking } \\
\text { through } \\
\text { Overtown }\end{array}$ \\
\hline Sophie & $\mathrm{F}$ & $40-50$ & Black & Jamaica & $\begin{array}{l}\text { Resident/ } \\
\text { grocery employee }\end{array}$ & $\begin{array}{l}\text { November } \\
10,2014\end{array}$ & $\begin{array}{l}\text { Grocery in } \\
\text { Overtown }\end{array}$ \\
\hline Abdul & $\mathrm{M}$ & $50-65$ & Middle Eastern & Jordan & $\begin{array}{l}\text { Resident/ } \\
\text { grocery employee }\end{array}$ & $\begin{array}{l}\text { January 9, } \\
2015 \text { / } \\
\text { April 15, } \\
2015 \text { / } \\
\text { May 21, } \\
2015\end{array}$ & $\begin{array}{l}\text { Grocery in } \\
\text { Overtown }\end{array}$ \\
\hline Frank & $\mathrm{M}$ & $60-70$ & Black & USA & $\begin{array}{l}\text { Resident/ } \\
\text { business owner }\end{array}$ & $\begin{array}{l}\text { January 9, } \\
2015\end{array}$ & $\begin{array}{l}\text { Interviewee's } \\
\text { business in } \\
\text { Overtown }\end{array}$ \\
\hline Farid & $\mathrm{M}$ & $30-40$ & Black & $\overline{U S A}$ & Resident & $\begin{array}{l}\text { January 9, } \\
2015\end{array}$ & $\begin{array}{l}\text { Overtown } \\
\text { business / } \\
\text { Interviewee's } \\
\text { car }\end{array}$ \\
\hline
\end{tabular}




\begin{tabular}{|c|c|c|c|c|c|c|c|}
\hline Alyssa & $\mathrm{F}$ & $30-40$ & Black & USA & Government official & $\begin{array}{l}\text { January 9, } \\
2015\end{array}$ & $\begin{array}{l}\text { Interviewee's } \\
\text { office in } \\
\text { Overtown }\end{array}$ \\
\hline Jean & $\mathrm{M}$ & $35-45$ & Black & Unknown & Resident & $\begin{array}{l}\text { February } \\
23,2015 \text { / } \\
\text { March 18, } \\
2015 \text { / July } \\
30,2015\end{array}$ & $\begin{array}{l}\text { Camillus House } \\
\text { / } \\
\text { groundbreaking } \\
\text { event / Corner } \\
\text { of Overtown } \\
\text { block }\end{array}$ \\
\hline Charles & $\mathrm{M}$ & $50-60$ & Black & USA & Nonprofit leader & $\begin{array}{l}\text { February } \\
24,2015\end{array}$ & Via telephone \\
\hline Candice & $\mathrm{F}$ & $25-35$ & Black & Unknown & Resident & $\begin{array}{l}\text { March 12, } \\
2015\end{array}$ & $\begin{array}{l}\text { Bus stop in } \\
\text { Overtown }\end{array}$ \\
\hline Luis & $\mathrm{M}$ & $45-55$ & White/Latino & $\begin{array}{l}\text { Dominican } \\
\text { Republic }\end{array}$ & Grocery owner & $\begin{array}{l}\text { March 18, } \\
2015\end{array}$ & $\begin{array}{l}\text { Interviewee's } \\
\text { grocery in } \\
\text { Overtown }\end{array}$ \\
\hline Steve & $\mathrm{M}$ & $60-70$ & Black & USA & Government official & $\begin{array}{l}\text { March 30, } \\
2015\end{array}$ & $\begin{array}{l}\text { Interviewee's } \\
\text { office in City } \\
\text { Hall }\end{array}$ \\
\hline Vernell & $\mathrm{M}$ & $70-80$ & Black & USA & $\begin{array}{l}\text { Resident/Pastor/ } \\
\text { Business owner }\end{array}$ & $\begin{array}{l}\text { April 16, } \\
2015\end{array}$ & $\begin{array}{l}\text { Interviewee's } \\
\text { business in } \\
\text { Overtown }\end{array}$ \\
\hline Zahra & $\mathrm{F}$ & $40-50$ & Black & Unknown & Nonprofit leader & $\begin{array}{l}\text { April 28, } \\
2015\end{array}$ & $\begin{array}{l}\text { Interviewee's } \\
\text { office in } \\
\text { Overtown }\end{array}$ \\
\hline Marvin Dunn & $\mathrm{M}$ & $70-80$ & Black & USA & $\begin{array}{l}\text { Nonprofit leader/ } \\
\text { Gardener }\end{array}$ & $\begin{array}{l}\text { April 29, } \\
2015 / \\
\text { August 3, } \\
2016\end{array}$ & $\begin{array}{l}\text { Interviewee's } \\
\text { home in Miami- } \\
\text { Dade }\end{array}$ \\
\hline Ted & $\mathrm{M}$ & $55-65$ & Black & $\overline{\mathrm{USA}}$ & Contractor & $\begin{array}{l}\text { May 6, } \\
2015\end{array}$ & $\begin{array}{l}\text { Overtown } \\
\text { restaurant }\end{array}$ \\
\hline Ricardo & $\mathrm{M}$ & $50-60$ & White/Latino & Cuba & Supermarket owner & May 22, & Interviewee's \\
\hline
\end{tabular}




\begin{tabular}{|c|c|c|c|c|c|c|c|}
\hline Corona & & & & & & 2015 & $\begin{array}{l}\text { law office in } \\
\text { Miami-Dade }\end{array}$ \\
\hline Etta Thomas & $\mathrm{F}$ & $60-70$ & Black & USA & Grocery owner & $\begin{array}{l}\text { May 6, } \\
2015 \text { / } \\
\text { May 29, } \\
2015 \text { / } \\
\text { August 17, } \\
2016\end{array}$ & $\begin{array}{l}\text { Interviewee's } \\
\text { grocery in } \\
\text { Overtown }\end{array}$ \\
\hline Marta & $\mathrm{F}$ & $30-40$ & White/Latino & Unknown & Resident & $\begin{array}{l}\text { May 21, } \\
2015\end{array}$ & $\begin{array}{l}\text { In front of } \\
\text { interviewee's } \\
\text { apartment } \\
\text { complex in } \\
\text { Overtown }\end{array}$ \\
\hline Jorge & M & $55-65$ & Black & Cuba & Resident & $\begin{array}{l}\text { May 21, } \\
2015\end{array}$ & $\begin{array}{l}\text { Bus stop in } \\
\text { Overtown }\end{array}$ \\
\hline Benjamin & $\mathrm{M}$ & $50-60$ & Black & USA & Resident & $\begin{array}{l}\text { May 21, } \\
2015\end{array}$ & $\begin{array}{l}\text { Interviewee's } \\
\text { home }\end{array}$ \\
\hline Dwaine & M & $35-45$ & Black & Unknown & Resident/Gardener & $\begin{array}{l}\text { May 21, } \\
2015\end{array}$ & $\begin{array}{l}\text { Garden in } \\
\text { Overtown }\end{array}$ \\
\hline Greg & $\mathrm{M}$ & $45-55$ & White & USA & $\begin{array}{l}\text { Charitable food } \\
\text { employee }\end{array}$ & $\begin{array}{l}\text { May 29, } \\
2015\end{array}$ & $\begin{array}{l}\text { Interviewee's } \\
\text { place of work }\end{array}$ \\
\hline Mike & $\mathrm{M}$ & $30-40$ & Black & Unknown & $\begin{array}{l}\text { Charitable food } \\
\text { employee }\end{array}$ & $\begin{array}{l}\text { May 29, } \\
2015\end{array}$ & $\begin{array}{l}\text { Interviewee's } \\
\text { place of work }\end{array}$ \\
\hline $\begin{array}{l}\text { Ignatius } \\
\text { Murray }\end{array}$ & $\mathrm{M}$ & $60-75$ & Black & Jamaica & Resident/Gardener & $\begin{array}{l}\text { June 5, } \\
2015\end{array}$ & $\begin{array}{l}\text { Garden in } \\
\text { Overtown }\end{array}$ \\
\hline Jerry & $\mathrm{M}$ & $30-40$ & Black & Unknown & $\begin{array}{l}\text { Resident/ } \\
\text { Business owner }\end{array}$ & $\begin{array}{l}\text { June 9, } \\
2015\end{array}$ & $\begin{array}{l}\text { Interviewee's } \\
\text { business in } \\
\text { Overtown }\end{array}$ \\
\hline Darrelle & $\mathrm{M}$ & $35-45$ & Black & Unknown & Resident & $\begin{array}{l}\text { June 9, } \\
2015\end{array}$ & $\begin{array}{l}\text { Overtown } \\
\text { business }\end{array}$ \\
\hline Sharon & $\mathrm{F}$ & $60-75$ & Black & USA & Resident & $\begin{array}{l}\text { July 3, } \\
2015\end{array}$ & $\begin{array}{l}\text { Bus stop in } \\
\text { Overtown }\end{array}$ \\
\hline
\end{tabular}




\begin{tabular}{|c|c|c|c|c|c|c|c|}
\hline Isaiah & $\mathrm{M}$ & $30-40$ & Black & USA & $\begin{array}{l}\text { Resident/ } \\
\text { Cook for the } \\
\text { longshoremen }\end{array}$ & $\begin{array}{l}\text { July } 3 \text {, } \\
2015\end{array}$ & $\begin{array}{l}\text { Outside the } \\
\text { Longshoremen's } \\
\text { hall }\end{array}$ \\
\hline Barbara & $\mathrm{F}$ & $60-75$ & Black & USA & $\begin{array}{l}\text { Resident/ } \\
\text { Community leader }\end{array}$ & $\begin{array}{l}\text { June 5, } \\
2015\end{array}$ & Overtown \\
\hline Hector & $\mathrm{M}$ & $25-35$ & White/Latino & Unknown & $\begin{array}{l}\text { Son of apartment } \\
\text { complex owner }\end{array}$ & $\begin{array}{l}\text { July 10, } \\
2015\end{array}$ & $\begin{array}{l}\text { Interviewee's } \\
\text { office in } \\
\text { Overtown }\end{array}$ \\
\hline Rashad & $\mathrm{M}$ & $45-55$ & Black & Unknown & Restaurant owner & $\begin{array}{l}\text { July 10, } \\
2015\end{array}$ & $\begin{array}{l}\text { Interviewee's } \\
\text { business in } \\
\text { Overtown }\end{array}$ \\
\hline John & $\mathrm{M}$ & $45-60$ & White & USA & $\begin{array}{l}\text { PI of research in } \\
\text { Overtown }\end{array}$ & $\begin{array}{l}\text { July 14, } \\
2015\end{array}$ & $\begin{array}{l}\text { Interviewee's } \\
\text { office in Miami- } \\
\text { Dade }\end{array}$ \\
\hline Freddie & $\mathrm{M}$ & $60-70$ & Black & USA & Public school teacher & $\begin{array}{l}\text { July 16, } \\
2015\end{array}$ & $\begin{array}{l}\text { Public school in } \\
\text { Overtown }\end{array}$ \\
\hline Alonzie & $\mathrm{M}$ & $30-40$ & Black & Unknown & Restaurant chef & $\begin{array}{l}\text { July } 30 \\
2015\end{array}$ & $\begin{array}{l}\text { Restaurant in } \\
\text { Overtown }\end{array}$ \\
\hline Johnny & M & $60-70$ & Middle Eastern & Unknown & Grocery owner & $\begin{array}{l}\text { August 4, } \\
2015\end{array}$ & $\begin{array}{l}\text { Interviewee's } \\
\text { grocery in } \\
\text { Overtown }\end{array}$ \\
\hline Gloria & $\mathrm{F}$ & $50-60$ & Black & USA & Server at restaurant & $\begin{array}{l}\text { August 4, } \\
2015\end{array}$ & $\begin{array}{l}\text { Restaurant in } \\
\text { Overtown }\end{array}$ \\
\hline Hector & $\mathrm{M}$ & $45-60$ & White/Latino & Unknown & $\begin{array}{l}\text { Supermarket } \\
\text { manager }\end{array}$ & $\begin{array}{l}\text { August 17, } \\
2016\end{array}$ & $\begin{array}{l}\text { Supermarket in } \\
\text { Overtown }\end{array}$ \\
\hline Darien & $\mathrm{M}$ & $20-25$ & Black & Haiti & Resident & $\begin{array}{l}\text { October 5, } \\
2016\end{array}$ & $\begin{array}{l}\text { Supermarket in } \\
\text { Overtown }\end{array}$ \\
\hline Cory & $\mathrm{M}$ & $20-25$ & Black & Unknown & Resident & $\begin{array}{l}\text { October 5, } \\
2016\end{array}$ & $\begin{array}{l}\text { Supermarket in } \\
\text { Overtown }\end{array}$ \\
\hline Jodie & $\mathrm{F}$ & $50-60$ & Black & Jamaica & $\begin{array}{l}\text { Partner of Overtown } \\
\text { resident }\end{array}$ & $\begin{array}{l}\text { October 5, } \\
2016\end{array}$ & $\begin{array}{l}\text { Supermarket in } \\
\text { Overtown }\end{array}$ \\
\hline Jeanelle & $\mathrm{F}$ & $25-35$ & Black/Latino & USA & Resident & October 5, & Supermarket in \\
\hline
\end{tabular}




\begin{tabular}{|l|l|l|l|l|l|l|l|}
\hline & & & & & & 2016 & Overtown \\
\hline Darita & F & $55-65$ & Black & Guatemala & Resident & $\begin{array}{l}\text { October 5, } \\
2016\end{array}$ & $\begin{array}{l}\text { Supermarket in } \\
\text { Overtown }\end{array}$ \\
\hline Armando & M & $50-60$ & White/Latino & Unknown & Business owner & $\begin{array}{l}\text { October 5, } \\
2016\end{array}$ & $\begin{array}{l}\text { Supermarket in } \\
\text { Overtown }\end{array}$ \\
\hline Tony & M & $50-60$ & White/Latino & Unknown & Supermarket vendor & $\begin{array}{l}\text { October 5, } \\
2016\end{array}$ & $\begin{array}{l}\text { Supermarket in } \\
\text { Overtown }\end{array}$ \\
\hline Joe & M & $55-65$ & Black & Unknown & CRA official & $\begin{array}{l}\text { October 5, } \\
\text { 2016 }\end{array}$ & $\begin{array}{l}\text { Supermarket in } \\
\text { Overtown }\end{array}$ \\
\hline Patricia & F & $55-65$ & Black & Unknown & Resident & $\begin{array}{l}\text { October 5, } \\
\text { 2016 }\end{array}$ & $\begin{array}{l}\text { Supermarket in } \\
\text { Overtown }\end{array}$ \\
\hline
\end{tabular}


VITA

\section{WILLIAM HALL}

2014-2016

PhD Candidate, Global \& Sociocultural Studies

Florida International University

Miami, Florida

Dissertation Year Fellow

Florida International University

Miami, Florida

Dissertation Research Fellow

Department of Black Studies

University of California, Santa Barbara

Christine Mirzayan Science \& Technology Policy Fellow

National Academies of Science, Medicine, and Engineering Washington, D.C.

$2010-2014$

Research Assistant, NSF Urban Long-Term Research Area Exploratory Grant, "Double Exposures: Socio-ecological Vulnerabilities in the Miami-Dade Urban Region."

Principal Investigator: Gail Hollander (FIU)

Teaching Assistant, Global \& Sociocultural Studies Florida International University

Miami, Florida

PhD Student, Global \& Sociocultural Studies

Florida International University

Miami, Florida

2007

B.A. Liberal Studies

Florida International University

Miami, Florida

\section{PUBLICATIONS AND PRESENTATIONS}

Hall, B. and Santoro, D. 2015. Learning Race Through Place and Time: Critical Geographic Approaches to Antiracist Collaborative Ethnography. Practicing Anthropology 37(4): 18-22.

Hall, B. 2015. Food Stamps and WIC. In Food Issues: An Encyclopedia, (Ed.) Ken Albala, SAGE Publications, Thousand Oaks: CA, pp. 626-632. 
Hall, B. 2015. Organizing the New Food Labor Movement: From Neoliberal Alternatives to Worker-based Justice. Journal of Agriculture, Food Systems, and Community Development 5(4): 91-94.

Ogden, L., Hall, B., and Tanita, K. 2013. Animals, Plants, People, and Things: A Review of Multispecies Ethnography. Environment and Society 4: 5-24.

Faria, C., Hall, B., Oswaha, A., and Scott, D. 2015. Supporting South Sudanese Diasporic Nation-Building: Investigating the Key Impediments and Rewards of Post-Conflict Return. Report for Humanity United.

Hall, B. November, 2015. 'They Tore Down My Favorite Place to Eat': Redevelopment and Shifting Foodscapes in Miami's Overtown Community. American Anthropological Association Annual Meeting, Denver, CO.

Hall, B. April, 2015. Before Food Deserts: Reconstructing Overtown's Neighborhood Food Environment from Jim Crow to Urban Renewal in Miami, FL. Association of American Geographers Annual Meeting, Chicago, IL.

Hall, B., and Santoro, D. March, 2014. Dreaming Together: Anti-racist Ethnography in Practice in Tallahassee, FL. Society for Applied Anthopology Annual Meeting, Albuquerque, NM.

Hall, B. April, 2012 Subsistence and the City: Making an Urban Food Commons? Dimensions of Political Ecology Conference, University of Kentucky, Lexington, KY.

Hall, B. February, 2012 Food Justice in Miami: Alternative Development Through Interculturality, Association of American Geographers Annual Meeting, New York, NY.

Hall, B. April, 2011 Sustainable Agriculture Initiatives in Urban Communities: Reconfiguring Miami's Foodshed, Association of American Geographers Annual Meeting, Seattle. 